Prepared in cooperation with Cherokee Metropolitan District, El Paso County, Meridian Service Metropolitan District, Mountain View Electric Association, Upper Black Squirrel Creek Groundwater Management District, Woodmen Hills Metropolitan District, Colorado State Land Board, Colorado Water Conservation Board, and the stakeholders represented in the Groundwater Quality Study Committee of El Paso County

\title{
Groundwater Quality, Age, and Susceptibility and Vulnerability to Nitrate Contamination with Linkages to Land Use and Groundwater Flow, Upper Black Squirrel Creek Basin, Colorado, 2013
}

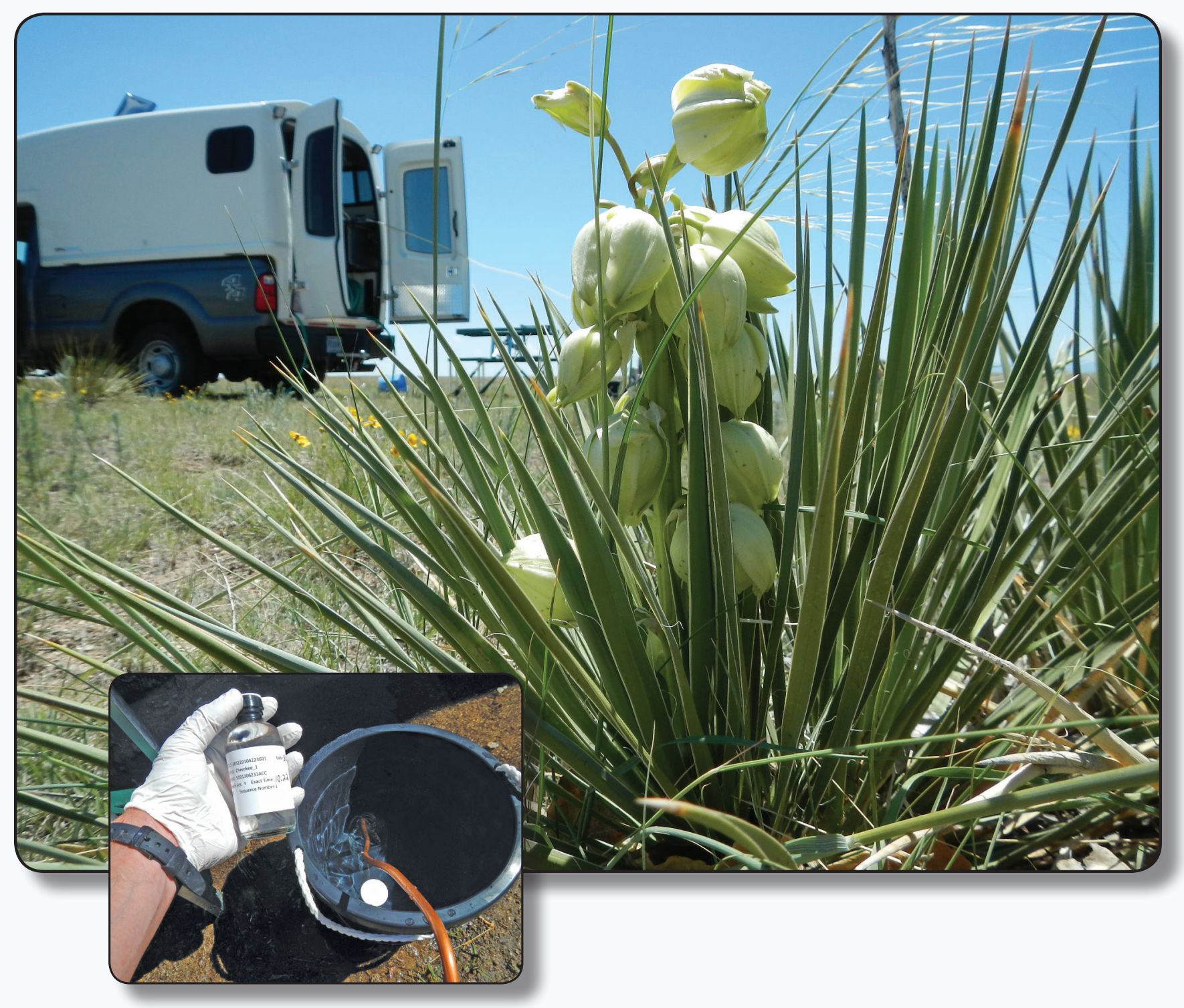

Scientific Investigations Report 2016-5020 
Cover. Upper left, Tributary to Brackett Creek south of Peyton, Colorado. Lower left, Water-quality sampling in the primary aquifer, Upper Black Squirrel Creek Basin, Colorado. Photographs from U.S. Geological Survey. 


\section{Groundwater Quality, Age, and Susceptibility and Vulnerability to Nitrate Contamination with Linkages to Land Use and Groundwater Flow, Upper Black Squirrel Creek Basin, Colorado, 2013}

By Tristan P. Wellman and Michael G. Rupert

Prepared in cooperation with Cherokee Metropolitan District, El Paso County, Meridian Service Metropolitan District, Mountain View Electric Association, Upper Black Squirrel Creek Groundwater Management District, Woodmen Hills Metropolitan District, Colorado State Land Board, Colorado Water Conservation Board, and the stakeholders represented in the Groundwater Quality Study Committee of El Paso County

Scientific Investigations Report 2016-5020 


\title{
U.S. Department of the Interior SALLY JEWELL, Secretary
}

\section{U.S. Geological Survey Suzette M. Kimball, Director}

\author{
U.S. Geological Survey, Reston, Virginia: 2016
}

For more information on the USGS - the Federal source for science about the Earth, its natural and living resources, natural hazards, and the environment—visit http://www.usgs.gov or call 1-888-ASK-USGS.

For an overview of USGS information products, including maps, imagery, and publications, visit http://www.usgs.gov/pubprod/.

Any use of trade, firm, or product names is for descriptive purposes only and does not imply endorsement by the U.S. Government.

Although this information product, for the most part, is in the public domain, it also may contain copyrighted materials as noted in the text. Permission to reproduce copyrighted items must be secured from the copyright owner.

Suggested citation:

Wellman, T.P., and Rupert, M.G., 2016, Groundwater quality, age, and susceptibility and vulnerability to nitrate contamination with linkages to land use and groundwater flow, Upper Black Squirrel Creek Basin, Colorado, 2013: U.S. Geological Survey Scientific Investigations Report, 2016-5020, 78 p., http://dx.doi.org/10.3133/sir20165020.

ISSN 2328-0328 (online) 


\section{Acknowledgments}

The authors thank Sean Chambers of Cherokee Metropolitan District, Elaine Kleckner of El Paso County, and all members of the El Paso County Groundwater Quality Study Committee, for their important individual contributions throughout this study. At an organizational level, the authors thank Cherokee Metropolitan District, El Paso County, Meridian Service Metropolitan District, Mountain View Electric Association, Upper Black Squirrel Creek Groundwater Management District, Woodmen Hills Metropolitan District, Colorado State Land Board, Colorado Water Conservation Board, and the stakeholders represented in the Groundwater Quality Study Committee of El Paso County. The Colorado Division of Water Resources and Colorado Springs Utilities are also acknowledged for their financial support for this project. The study benefited from the many landowners who permitted the use of their wells for collection of water samples, and the staff of Cherokee Metropolitan District and Meridian Service Metropolitan District for access to their wells to collect groundwater-quality samples. Internally, the authors thank Chris Brown, Dustin Ethredge, Michael Holmberg, and Rodger Ortiz of the U.S. Geological Survey (USGS) who helped with the groundwater sampling. The authors thank Kenneth Skinner and Joseph Ayotte of the USGS for their formal internal peer review comments. Lastly, additional technical reviews were provided by Bill Banks, Ned Banta, Peter McMahon, Jeanette Oden, and Katie Walton-Day of the USGS, which helped to improve the report and were greatly appreciated. 



\section{Contents}

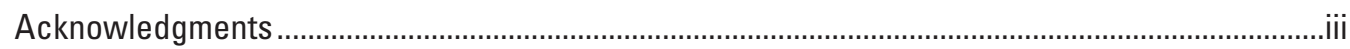

Abstract

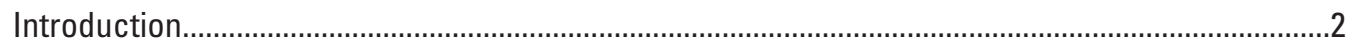

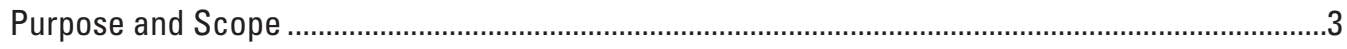

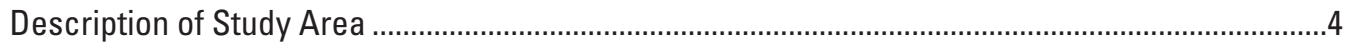

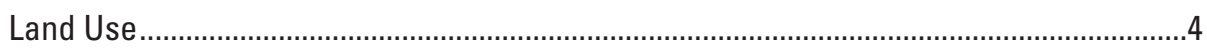

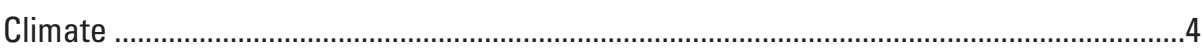

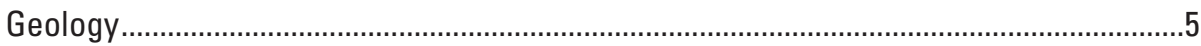

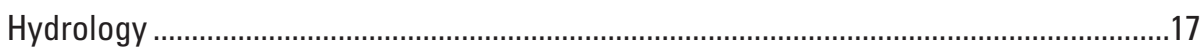

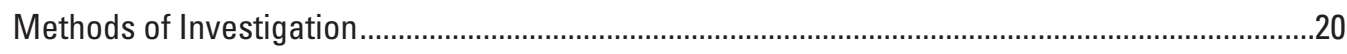

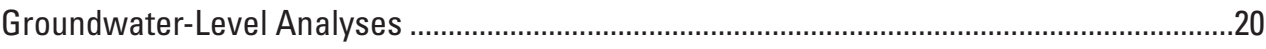

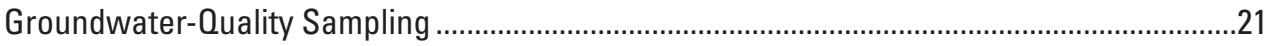

Quality Assurance and Quality Control ..............................................................................22

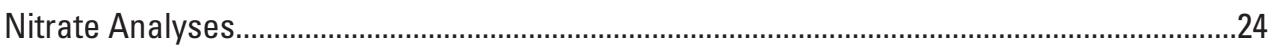

Groundwater Age

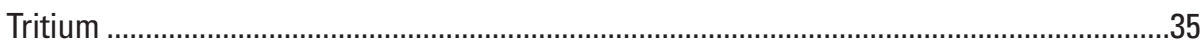

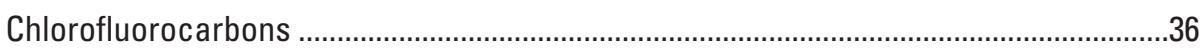

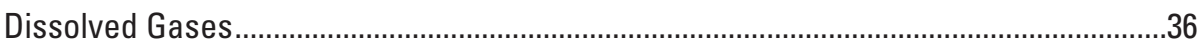

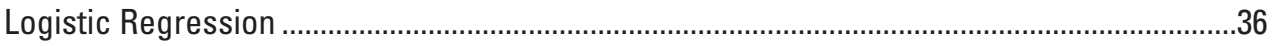

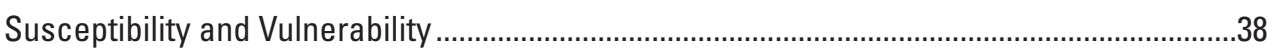

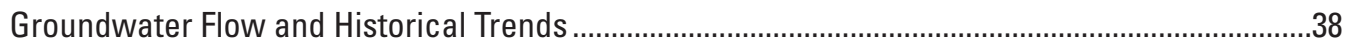

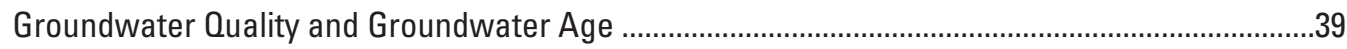

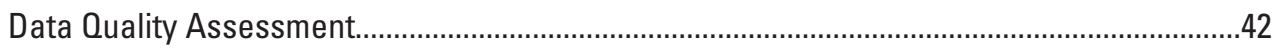

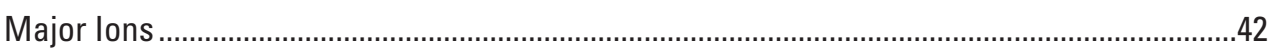

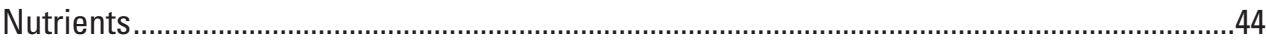

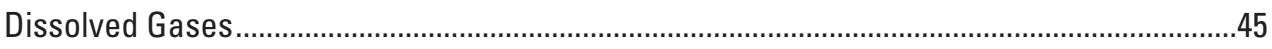

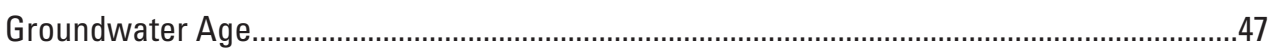

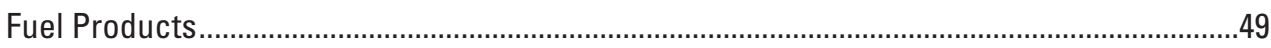

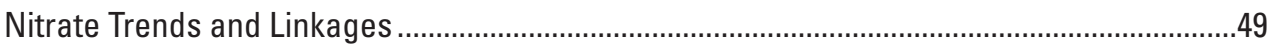

Susceptibility and Vulnerability to Nitrate ……........................................................................

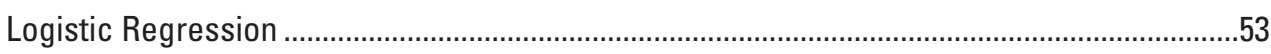

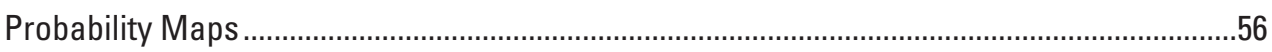

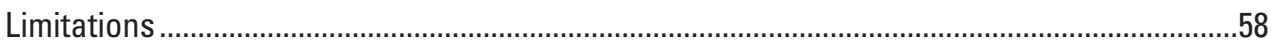

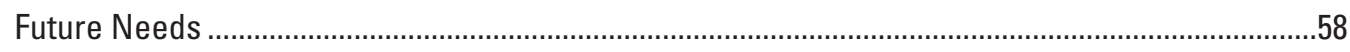

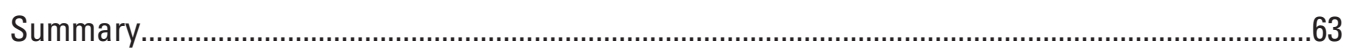

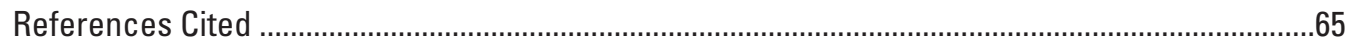

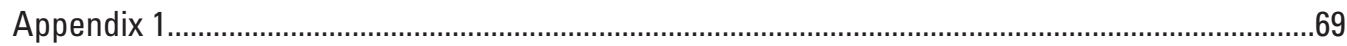




\section{Figures}

1. Map showing site location of primary aquifer of the Black Squirrel Management District in Water Division 2 about 25 kilometers east of Colorado Springs, El Paso County, Colorado....

2. Photograph showing large agricultural pivot on irrigated land surrounded by senescent (dry) native grassland.

3. Pie chart showing classifications of land use and associated percent by area, Upper Black Squirrel Creek Basin, El Paso County, Colorado ...

4-16. Maps showing:

4. Land use in the Upper Black Squirrel Creek Basin, El Paso County, Colorado... 66

5. Domestic septic systems in the Upper Black Squirrel Creek Basin, El Paso County, Colorado. .7

6. Average yearly precipitation from Parameter-Elevation Regressions on Independent Slopes Model (PRISM) 30-year normals from 1981 to 2010, Upper Black Squirrel Creek Basin, El Paso County, Colorado .8

7. Unconsolidated Quaternary deposits within the primary aquifer from Tweto (1979), Upper Black Squirrel Creek Basin, El Paso County, Colorado.

8. Unconsolidated Quaternary deposits within the primary aquifer from Scott (1974), Upper Black Squirrel Creek Basin, El Paso County, Colorado.

9. Soil taxonomy (order) overlying the primary aquifer, Upper Black Squirrel Creek Basin, Colorado

10. Soil organic matter overlying the primary aquifer, Upper Black Squirrel Creek Basin, Colorado

11. Soil porosity overlying the primary aquifer, Upper Black Squirrel Creek Basin, Colorado.

12. Soil clay content overlying the primary aquifer, Upper Black Squirrel Creek Basin, Colorado.

13. Soil drainage classification overlying the primary aquifer, Upper Black Squirrel Creek Basin, Colorado...

14. Soil saturated hydraulic conductivity overlying the primary aquifer, Upper Black Squirrel Creek Basin, Colorado...

15. Soil available water storage to 25-centimeter depth overlying the primary aquifer, Upper Black Squirrel Creek Basin, Colorado

16. Estimated thicknesses of unconsolidated deposits of the primary aquifer from Topper and Horn (2011), Upper Black Squirrel Creek Basin, Colorado

17. Photographs showing installation of a monitoring well, Upper Black Squirrel

Creek Basin, Colorado

18. Photographs showing water-quality sampling in the primary aquifer, Upper Black Squirrel Creek Basin, Colorado

19. Graph showing historical depths to groundwater in the primary aquifer, 1975-2015, Upper Black Squirrel Creek Basin, Colorado .

20-22. Maps showing:

20. Median water-table elevations and groundwater flow directions in the primary aquifer, 2000-2013, Upper Black Squirrel Creek Basin, Colorado.

21. Agricultural region determined using land satellite imagery to define crop areas, 1999-2014, Upper Black Squirrel Creek Basin, Colorado.....

22. Spatial distribution of the 50 wells sampled for water quality and age, well depth, and well type, Upper Black Squirrel Creek Basin, Colorado 
23. Piper diagram showing major-ion chemistry of groundwater samples from the primary aquifer, Upper Black Squirrel Creek Basin, Colorado

24. Map showing observed nitrate concentrations at 50 wells within the primary aquifer, Upper Black Squirrel Creek Basin, Colorado

25. Map showing groundwater age or tritium classification (pre- and post-dates 1950s), Upper Black Squirrel Creek Basin, Colorado.

26. Box plot showing median nitrate concentrations with 25 th to 75 th percentile confidence intervals when examined over 5-year periods within the primary aquifer, 1985-2015, Upper Black Squirrel Creek Basin, Colorado

27. Box plots showing nitrate concentrations in groundwater attributed to: $A$, septic use, regional effect of agriculture (fig. 21, "Agricultural region"), and farmland (fig. 21, "500-meter buffer around crops"), and $B$, land use and well use type within the primary aquifer, Upper Black Squirrel Creek Basin, Colorado..........51

28. Pie charts and graph showing percentage of nitrate in groundwater contributed by land use and septic use for locations $A$, outside of the agricultural region (fig. 21, "Agricultural region") and $B$, inside of the agricultural region, and $C$, nitrate effect defined as percent nitrate $(\% \mathrm{~N})$ divided by percent area (\% area) per land use within the primary aquifer, Upper Black Squirrel Creek Basin, Colorado

29. Box plots showing nitrate concentrations in groundwater categorized by: $A$, geologic classifications by Scott (1974) and Tweto (1979) and B, Soil Survey Geographic database (SSURGO) soil taxonomy (order and group)

30. Graphs showing calibration evaluation of the four $(A-D)$ logistic regression models developed in this investigation with details given in table 7

31-34. Maps showing:

31. Mid-level aquifer susceptibility (all samples) given as the probability of detecting nitrate concentrations in groundwater greater than 5 milligrams per liter, Upper Black Squirrel Creek Basin, Colorado, 2013.

32. Low-level aquifer vulnerability (all samples) given as the probability of detecting nitrate concentrations in groundwater greater than 2.5 milligrams per liter, Upper Black Squirrel Creek Basin, Colorado, 2013.

33. Mid-level aquifer vulnerability (all samples) given as the probability of detecting nitrate concentrations in groundwater greater than 5 milligrams per liter, Upper Black Squirrel Creek Basin, Colorado, 2013.

34. Mid-level aquifer vulnerability (two outliers removed) given as the probability of detecting nitrate concentrations in groundwater greater than 5 milligrams per liter, Upper Black Squirrel Creek Basin, Colorado, 2013

\section{Tables}

1. Selected well identification, coordinate location, depth, and type, depth to groundwater, and land use, Upper Black Squirrel primary aquifer, El Paso County, Colorado, 2013

2. Selected major-ion, nutrient, and fuel products data from groundwater, Upper Black Squirrel primary aquifer, El Paso County, Colorado, 2013

3. Dissolved gas data analyzed from groundwater samples collected from the Upper Black Squirrel primary aquifer, El Paso County, Colorado, 2013.

4. Selected groundwater-quality data used to interpret groundwater recharge ages using chlorofluorocarbons and tritium, Upper Black Squirrel primary aquifer, El Paso County, Colorado, 2013. 
5. Analyses of blank samples of major ions, nutrients, and fuel products in groundwater, Upper Black Squirrel primary aquifer, El Paso County, Colorado, 2013 ...

6. Analysis of replicate samples of major ions, nutrients, and fuel products in groundwater, Upper Black Squirrel primary aquifer, El Paso County, Colorado, 2013.

7. Four logistic regression models showing the probability that nitrate concentrations in groundwater exceeded specified limits with measures of model fits: $(A)$ mid-level aquifer susceptibility of nitrate concentrations above $5.0 \mathrm{mg} / \mathrm{L},(B)$ low-level aquifer vulnerability of nitrate concentrations above $2.5 \mathrm{mg} / \mathrm{L}$, and $(C)$ mid-level aquifer vulnerability of nitrate concentrations above $5.0 \mathrm{mg} / \mathrm{L}$ using all 50 samples, and (D) mid-level aquifer vulnerability of nitrate concentrations above $5.0 \mathrm{mg} / \mathrm{L} \mathrm{using}$ 48 samples with data from wells 1 and 2 removed.

\section{Appendix Tables}

1-1. Wells to estimate historical depth to groundwater during 1975-2015, set 1 of 4 .............70

1-2. Wells to estimate historical depth to groundwater during 1975-2015, set 2 of $4 \ldots \ldots \ldots \ldots . . .71$

1-3. Wells to estimate historical depth to groundwater during 1975-2015, set 3 of 4 .............72

1-4. Wells to estimate historical depth to groundwater during $1975-2015$, set 4 of 4 .............73

1-5. Wells used to evaluate median water-table elevations during 2000-2013, set 1 of 2 .........74

1-6. Wells used to evaluate median water-table elevations during 2000-2013, set 2 of 2 .........75

1-7. Wells used to evaluate median nitrate concentration during 1985-2013, set 1 of 2...........76

1-8. Wells used to evaluate median nitrate concentration during 1985-2013, set 2 of 2...........77

\section{Conversion Factors}

\begin{tabular}{lcl}
\hline Multiply & By & To obtain \\
\hline meter $(\mathrm{m})$ & Length & \\
kilometer $(\mathrm{km})$ & 3.281 & foot $(\mathrm{ft})$ \\
& 0.6214 & mile $(\mathrm{mi})$ \\
\hline square meter $\left(\mathrm{m}^{2}\right)$ & Area & \\
square kilometer $\left(\mathrm{km}^{2}\right)$ & 0.0002471 & acre \\
\hline & 0.3861 & square mile $\left(\mathrm{mi}^{2}\right)$ \\
\hline cubic meter $\left(\mathrm{m}^{3}\right)$ & Volume & \\
liter $(\mathrm{L})$ & 264.2 & gallon $(\mathrm{gal})$ \\
cubic meter $\left(\mathrm{m}^{3}\right)$ & 0.2642 & gallon $(\mathrm{gal})$ \\
\hline & 0.0008107 & acre-foot $(\mathrm{acre}-\mathrm{ft})$ \\
\hline meter per day $(\mathrm{m} / \mathrm{d})$ & Hydraulic conductivity & \\
\hline & 3.281 & foot per day $(\mathrm{ft} / \mathrm{d})$ \\
\hline meter per kilometer $(\mathrm{m} / \mathrm{km})$ & Hydraulic gradient & foot per mile $(\mathrm{ft} / \mathrm{mi})$ \\
\hline
\end{tabular}

Temperature in degrees Celsius $\left({ }^{\circ} \mathrm{C}\right)$ may be converted to degrees Fahrenheit $\left({ }^{\circ} \mathrm{F}\right)$ as follows: ${ }^{\circ} \mathrm{F}=\left(1.8 \mathrm{x}^{\circ} \mathrm{C}\right)+32$

Temperature in degrees Fahrenheit $\left({ }^{\circ} \mathrm{F}\right)$ may be converted to degrees Celsius $\left({ }^{\circ} \mathrm{C}\right)$ as follows: ${ }^{\circ} \mathrm{C}=\left({ }^{\circ} \mathrm{F}-32\right) / 1.8$

Vertical coordinate information is referenced to the North American Vertical Datum of 1988 (NAVD 88).

Horizontal coordinate information is referenced to the North American Datum of 1983 (NAD 83).

Elevation, as used in this report, refers to distance above the vertical datum. 


\title{
Groundwater Quality, Age, and Susceptibility and Vulnerability to Nitrate Contamination with Linkages to Land Use and Groundwater Flow, Upper Black Squirrel Creek Basin, Colorado, 2013
}

\author{
By Tristan P. Wellman and Michael G. Rupert
}

\begin{abstract}
The Upper Black Squirrel Creek Basin is located about 25 kilometers east of Colorado Springs, Colorado. The primary aquifer is a productive section of unconsolidated deposits that overlies bedrock units of the Denver Basin and is a critical resource for local water needs, including irrigation, domestic, and commercial use. The primary aquifer also serves an important regional role by the export of water to nearby communities in the Colorado Springs area. Changes in land use and development over the last decade, which includes substantial growth of subdivisions in the Upper Black Squirrel Creek Basin, have led to uncertainty regarding the potential effects to water quality throughout the basin. In response, the U.S. Geological Survey, in cooperation with Cherokee Metropolitan District, El Paso County, Meridian Service Metropolitan District, Mountain View Electric Association, Upper Black Squirrel Creek Groundwater Management District, Woodmen Hills Metropolitan District, Colorado State Land Board, and Colorado Water Conservation Board, and the stakeholders represented in the Groundwater Quality Study Committee of El Paso County conducted an assessment of groundwater quality and groundwater age with an emphasis on characterizing nitrate in the groundwater.

Groundwater-quality samples were collected from 50 randomly selected wells between May and June 2013. The samples were analyzed for major ions, nutrients, dissolved gases, tritium $\left({ }^{3} \mathrm{H}\right)$, chlorofluorocarbons (CFC-11, CFC-12, and $\mathrm{CFC}-113$ ), and fuel products (such as benzene, toluene, ethylbenzene, and xylenes). None of the groundwater samples exceeded the U.S. Environmental Protection Agency (EPA) National Primary Drinking Water Regulations for primary maximum contaminant levels (MCL) for major ions. Secondary maximum contaminant levels, which are not health concerns and affect mainly taste, color, or odor of the water, were observed in rare instances for $\mathrm{pH}$ ( 2 samples), chloride ( 1 sample), iron ( 3 samples), and manganese ( 8 samples). The secondary maximum contaminant level for total dissolved solids was also exceeded for two samples.
\end{abstract}

Nitrate (nitrite plus nitrate as nitrogen in groundwater) was elevated above the estimated background concentration of natural recharge waters of 1 milligram per liter $(\mathrm{mg} / \mathrm{L})$ in 44 of the 50 wells sampled and showed a median concentration of $5.4 \mathrm{mg} / \mathrm{L}$. Nitrate concentrations were above the MCL of $10 \mathrm{mg} / \mathrm{L}$ in 5 of the 50 wells sampled and above half of the EPA MCL ( $5 \mathrm{mg} / \mathrm{L})$ in 27 of the 50 wells sampled, which included samples above the MCL. Dissolved-oxygen concentrations exceeded $0.5 \mathrm{mg} / \mathrm{L}$ in 95 percent of reported values ( 40 of 42 samples) and exceeded $2.0 \mathrm{mg} / \mathrm{L}$ in 90 percent of reported values ( 38 of 42 samples). The oxidized conditions observed in most areas indicate that nitrate from fertilizers and animal or human waste was geochemically stable and could persist in the groundwater for decades or perhaps longer. A historical analysis of median nitrate concentrations over nearly three decades showed an increase in nitrate of approximately $1 \mathrm{mg} / \mathrm{L}$ from 4.3 to $5.4 \mathrm{mg} / \mathrm{L}$, although the increase was not determined to be significantly different using nonparametric statistical methods.

Major-ion data indicate that groundwater representative of the primary aquifer was classified as calcium-sodium bicarbonate type water. Other water samples from wells located mainly along the periphery of the primary aquifer had cation-anion compositions consistent with distinct water sources, including groundwater contributions from the underlying bedrock aquifers. The areas with differentiable water sources were located mainly where alluvial deposits were thin and geologic contacts to the underlying bedrock aquifers were relatively shallow.

Nitrate concentrations in the groundwater were evaluated for relations to land use. An agricultural region was defined using a sequence of land satellite imagery. Groundwater flow directions interpreted from median water-table elevations measured from 2000 to 2013 were used in conjunction with cropland locations to define the agricultural region boundaries by encompassing potential pathways of nitrate transport in the groundwater from nitrogen-based fertilizers. A statistically significant higher median nitrate concentration was observed for areas inside the agricultural region $(6.7 \mathrm{mg} / \mathrm{L})$ compared 
to areas outside the agricultural region $(2.3 \mathrm{mg} / \mathrm{L})$, although median concentrations in both areas were below the MCL $(10 \mathrm{mg} / \mathrm{L})$. Median nitrate concentration was also significantly greater in land parcels with septic use $(4.9 \mathrm{mg} / \mathrm{L})$ compared to nonseptic parcels $(1.7 \mathrm{mg} / \mathrm{L})$. In general, agriculture or septic use was identified as the primary source of nitrate, depending on location, while commercial, county, grazing, and residential land uses were generally secondary sources of nitrate.

Apparent groundwater ages were estimated from chlorofluorocarbons (CFC-11, CFC-12, and CFC-113) and tritium $\left({ }^{3} \mathrm{H}\right)$ data using models that assumed piston flow and binary mixing (dilution of a young component with old, tracer-free water). The mean and median groundwater ages were about 30 years and the standard deviation was 6 years, indicating that most groundwater in the primary aquifer was "young" water that had recharged to the aquifer over the last few decades (post-1950s). The median fraction of young water was about 71 percent, and the standard deviation was 29 percent. The remaining water predated the 1950s, which may have originated from deeper geologic formations or may represent slow moving groundwater within the primary aquifer. Some of the oldest groundwater ages (older than 30 years) were observed in the upper reaches of the aquifer to the northwest where the primary aquifer is thin and intersects bedrock, supporting the hypothesis of geochemically distinct groundwater entering the primary aquifer from below. Groundwater that had reached the central part of the aquifer from upgradient areas of the basin was variable in age because of differences in flow paths and travel velocities. The groundwater age analysis showed that current (2013) land-use practices could affect water quality over decades to come, and that responses to remedial actions could be slow, especially for constituents, such as nitrate, that are stable under oxidized conditions.

Fuel products (including acetone, benzene, diisopropyl ether, ethylbenzene, methyl acetate, methyl tertiary butyl ether (MTBE), methyl tert-pentyl ether, m- + p-xylene, o-xylene, tert-amyl alcohol, tert-butyl alcohol, tert-butyl ethyl ether, and toluene) were analyzed in groundwater from 49 of the 50 wells. Water from seven sites had detections for fuel compounds; all concentrations were below MCL. The results provided assurance of water quality and a valuable baseline to evaluate future trends of fuel constituents as the region is further developed.

Probability maps were developed from logistic regression models to examine the likelihood that nitrate concentrations in groundwater exceeded specified levels. Susceptibility analysis examined relations between mid-level $(5.0 \mathrm{mg} / \mathrm{L})$ nitrate concentrations and climatic, hydrologic, and geologic variables; the significant variables were identified as depth to groundwater, soil organic matter, and soil water storage to 25 -centimeter $(\mathrm{cm})$ depth. The vulnerability assessments included natural factors driving susceptibility but also human factors related to land use and septic use. Vulnerability to lowlevel $(2.5 \mathrm{mg} / \mathrm{L})$ nitrate was related to depth to groundwater, septic zoning, and soil organic matter. The results highlighted that septic zoning affected low-level nitrate concentrations. Vulnerability to mid-level $(5.0 \mathrm{mg} / \mathrm{L})$ nitrate was examined using all 50 samples and also with two data outliers removed, which showed relatively high nitrate concentrations but also anomalous water chemistry or were located beyond the primary study area. Vulnerability to mid-level $(5.0 \mathrm{mg} / \mathrm{L})$ nitrate using all 50 samples was related to depth to groundwater, land use, septic use within a 500-meter (m) radius, soil water storage to a $25-\mathrm{cm}$ depth, soil organic matter, and whether a location was within the agricultural region. The mid-level $(5.0 \mathrm{mg} / \mathrm{L})$ vulnerability model using 48 samples (two outliers removed) produced the best overall fit and was related to the same variables as when using all samples except septic use. The results for mid-level vulnerability provided additional support that septic use was associated with low levels of nitrate in the groundwater. Soil properties and land use were identified as the main drivers of moderate nitrate concentrations. Probabilities of exceeding low-level nitrate concentrations were high in most areas with the lowest probabilities usually to the northwest along thin geologic deposits in the upper part of the basin.

The results of this investigation offer the foundational information needed for developing best management practices to mitigate nitrate contamination, basic concepts on water quality to aid public education, and information to guide regulatory measures if policy makers determine this is warranted. Science-based decision making will require continued monitoring and analysis of water quality in the future.

\section{Introduction}

The Upper Black Squirrel Creek Basin is located about 25 kilometers $(\mathrm{km})$ east of Colorado Springs in Water Division 2, El Paso County, Colorado (fig. 1). The primary aquifer is composed of permeable unconsolidated deposits of alluvium and aeolian sediment, and is considered primary because the majority of groundwater is transported within this unit (Watts, 1995). The near-surface unconsolidated deposits are underlain by the Denver Basin bedrock aquifers extending regionally across the Front Range, which encompasses the Denver metropolitan area. The Upper Black Squirrel Creek Ground Water Management District, herein referred to as the Black Squirrel Management District for brevity, traces the basic outline of the local basin boundary. All streams in the basin are ephemeral and provide intermittent sources of water with most streamflow occurring during periods of spring runoff and major storms.

Since the late 1800 s, the primary aquifer has provided a valuable source of water used for several purposes, including irrigation, domestic, and commercial uses. Water from the primary aquifer is used locally and exported to suburbs east of Colorado Springs. Although domestic and industrial water is exported out of the basin, return water is recharged back to the aquifer following wastewater treatment. Water used for irrigation and other agricultural purposes is an important economic driver for the region. Agriculture in many areas requires substantial water and has created clear contrasts to the native 


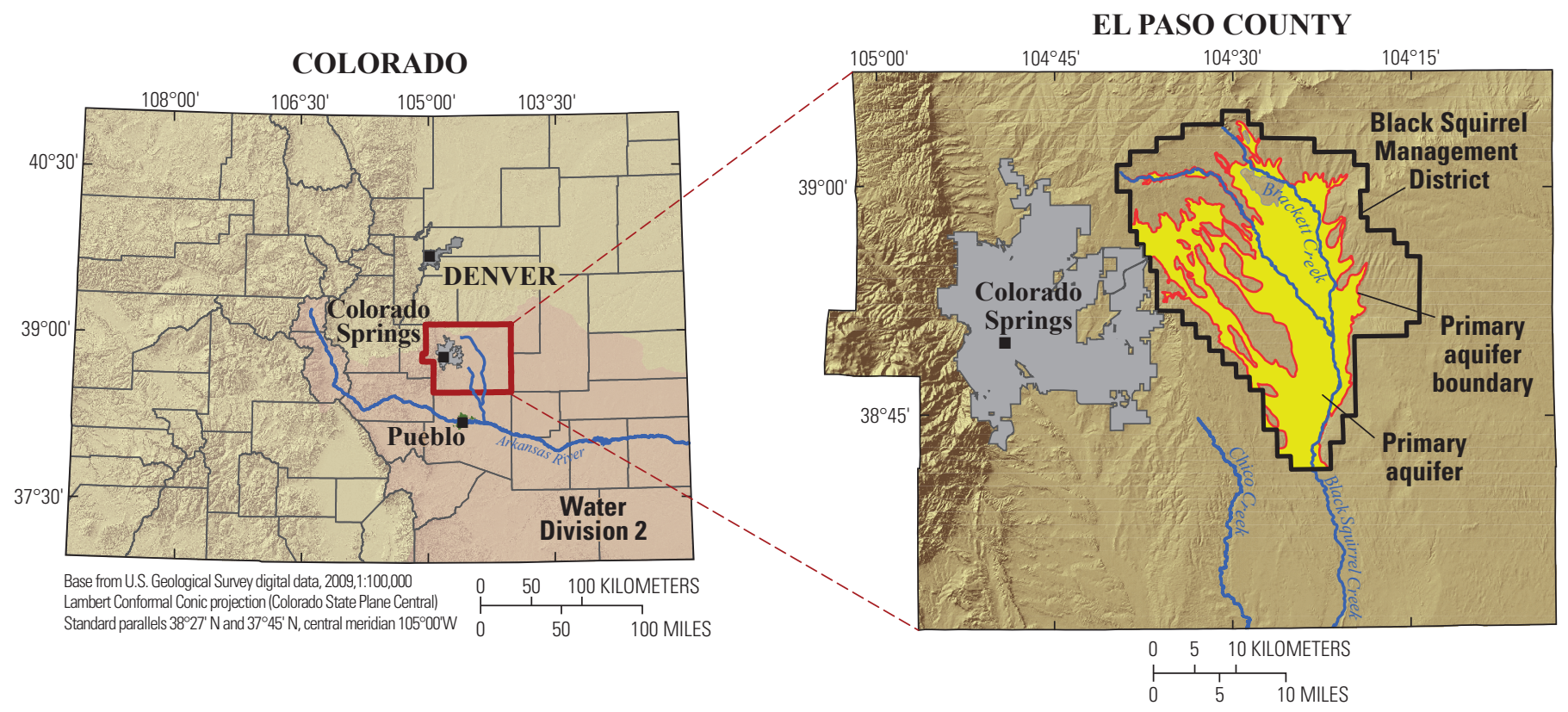

Figure 1. Site location is the primary aquifer of the Black Squirrel Management District in Water Division 2 about 25 kilometers east of Colorado Springs, El Paso County, Colorado.

vegetation (fig. 2). Since the mid-1950s, and because of extensive development, pumping of groundwater from storage in the aquifer resulted in declines of the water table up to several meters at some locations by the late 1980s (Buckles and Watts, 1988). Recently, water was over appropriated with water rights exceeding water supply (Upper Black Squirrel Creek Ground Water Management District, 2009).

Changes in land use and development over the last decade, which include substantial growth of subdivisions in the Upper Black Squirrel Creek Basin, have led to uncertainty over the potential effects to water quality throughout the basin. The El Paso County Board of County Commissioners held work sessions in early 2009 to discuss potential changes to the El Paso County Land Development Code, which led to adoption by the Board of Resolution Number 09-202 and interest to conduct a groundwater contamination study. The board then established the Groundwater Quality Study Committee, and work commenced during mid-2009. The first phase (Phase I) of the study, completed in April 2011, was a summary of the available data and literature search of studies completed in the basin (Topper and Horn, 2011). Earlier work by Topper (2008) was scoped to investigate the potential to use alluvial storage capacity as a tool for future storage and augmentation of existing groundwater resources. Quantification of alluvial storage capacity was a critical aspect of the Topper scope of work for the stakeholders at that time, and it followed the 2006 SB-193 Study (Underground Water Storage Study SB06-193), which identified potential alluvial storage areas including Upper Black Squirrel Creek Basin. For the current Phase II study, the U.S. Geological Survey (USGS) provided technical assistance for the Groundwater Quality Study Committee to examine groundwater quality in the aquifer. The USGS, in cooperation with committee representatives from Cherokee Metropolitan District, El Paso County, Meridian Service Metropolitan District, Mountain View Electric Association, Upper Black Squirrel Creek Groundwater Management District, Woodmen Hills Metropolitan District, Colorado State Land Board, and Colorado Water Conservation Board, and the stakeholders represented in the Groundwater Quality Study Committee of El Paso County conducted a study in 2013 to evaluate several components of groundwater quality. The analyses included evaluations of groundwater quality including major ions, nutrients, and fuel products, groundwater age dating using chlorofluorocarbons and tritium, assessments of susceptibility and vulnerability to nitrate $\left(\mathrm{NO}_{3}\right.$, defined as nitrite plus nitrate as nitrogen $\left[\mathrm{NO}_{2}^{-}+\mathrm{NO}_{3}^{-}-\mathrm{N}\right]$ in this report) contamination, and analyses of land-use effects and groundwater flow on nitrate distribution within the primary aquifer.

\section{Purpose and Scope}

The purpose of this report is to examine groundwater quality in the Upper Black Squirrel Creek Basin using groundwater samples collected from 50 wells in May and June 2013, and includes an evaluation of nutrients, fuel products, groundwater age, aquifer susceptibility and vulnerability to nitrate, and linkages between nitrate concentrations and land use, groundwater flow, and other site characteristics of the primary aquifer. The results can be used by governing authorities to improve decision making, enhance public education of local groundwater and drinking-water supplies, and guide long-term water-resource protection and management. 


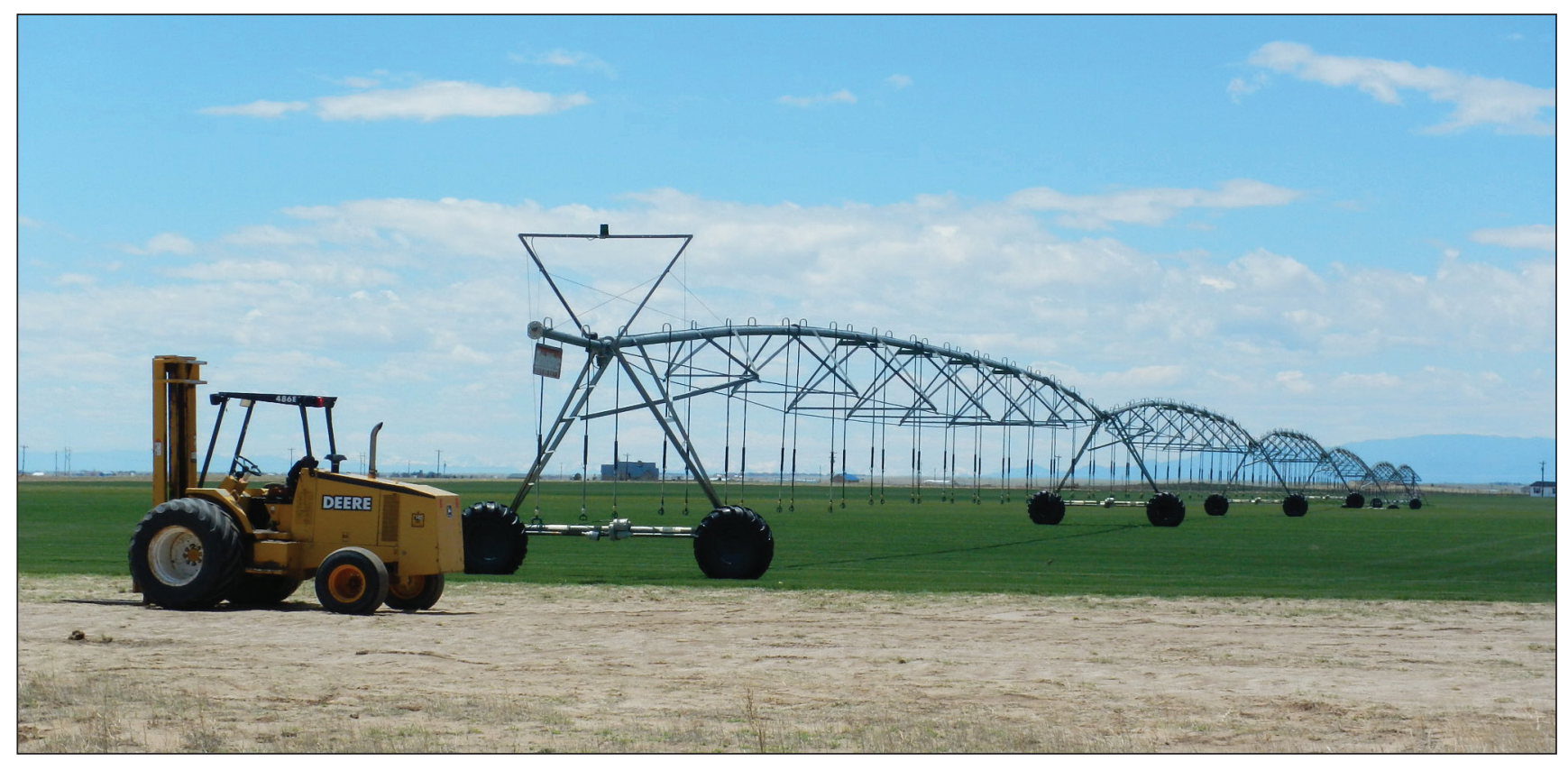

Figure 2. Large agricultural pivot on irrigated land surrounded by senescent (dry) native grassland.

\section{Description of Study Area}

The study area for this investigation is the primary aquifer of the Upper Black Squirrel Creek Basin, located about $25 \mathrm{~km}$ east of Colorado Springs (fig. 1). The primary aquifer extends about 435 square kilometers $\left(\mathrm{km}^{2}\right)$ and is bounded by the Black Squirrel Management District that follows the local basin boundary over about $900 \mathrm{~km}^{2}$. The boundary of the primary aquifer and approximate aquifer thickness were mapped by Topper (2008), who evaluated the hydrogeology of the primary aquifer to assess the potential for aquifer recharge and groundwater storage.

\section{Land Use}

The principal land-use type in the study area is grazing land. Urban and residential land was historically a secondary land use but has been on the increase in the region, particularly in the northwest part of the study area. Ranching and farming in the area date back to the 19th century. Between 1920 and 1940, several irrigation wells were drilled to meet the water needs from agriculture (Buckles and Watts, 1988). During the 1950s, acreage of irrigated cropland increased rapidly and many additional irrigation wells were drilled to accommodate increased water demands. Historically, some crops such as field corn have also been grown successfully without direct irrigation using dryland-farming methods. Turf grass for sod has also been introduced in the region.

Land use was defined by El Paso County using classifications given to tax assessor parcels (Ross A. Williams, El Paso County Information Technologies, written communication,
2014). Following discussions with El Paso County authorities, a simplified classification scheme of land use was adopted. Landuse types were partitioned into major categories and resolved in terms of percent by area; 62 percent grazing land, 26 percent residential ( 1 percent for lots less than 2.5 acres, 4 percent for lots between 2.5 and 5 acres, and 21 percent for lots larger than 5 acres), 8 percent county land that includes vacant land, 3 percent irrigated crops (agricultural and turf farms), and 1 percent commercial land (fig. 3). Most land-use types were distributed throughout the aquifer often in clustered areas, although grazing land was generally disperse (fig. 4). Irrigated land parcels were located mainly along a north-south transect in the central to eastern parts of the study area. Elsewhere irrigated land parcels were distributed intermittently; perhaps most notable is a turf farm on the western side of the study area (fig. 4, near sampling well 21 about $5 \mathrm{~km}$ southeast of Falcon). Clusters of small land parcels were located around the town of Falcon and to a lesser degree near the towns of Peyton and Ellicott, as well as other areas across the study area. Septic systems have been used extensively in inhabited areas and were authorized through permitting on land parcels (fig. 5).

\section{Climate}

The climate of the study area is semiarid. Over 2000-2013, mean monthly air temperature recorded at the Colorado Springs Airport ranged from 18 to 44 degrees Fahrenheit $\left({ }^{\circ} \mathrm{F}\right)$ in January and from 58 to $87^{\circ} \mathrm{F}$ in July (https://www.ncdc.noaa.gov/, accessed January 12, 2015). Estimates of average precipitation across the study area were developed by the PRISM Climate Group (PRISM Climate Group, 2012) using the Parameterelevation Regressions on Independent Slopes Model (PRISM) 


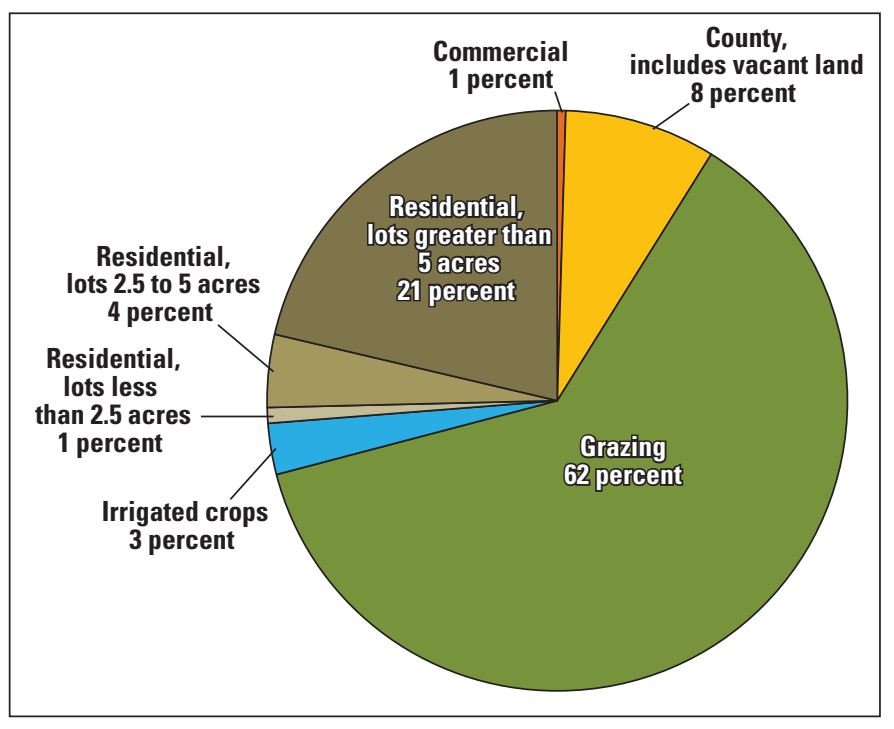

Figure 3. Classifications of land use and associated percent by area, Upper Black Squirrel Creek Basin, El Paso County, Colorado (http://adm.elpasoco.com/InformationTechnologies/ GeographicInformationSystems).

on 30-year normals from 1981 to 2010 over a grid scale of $800 \mathrm{~m}$. PRISM incorporated climatic point data and a digital elevation model (DEM) to generate gridded estimates of climatic parameters (fig. 6). Mean annual precipitation ranged from about 37 to 45 centimeters per year $(\mathrm{cm} / \mathrm{yr})$ in the southern part of the study area to about $55 \mathrm{~cm} / \mathrm{yr}$ in the northern part of the study area. Precipitation generally decreased in a general northwest to southeast direction from higher to lower elevations, which is typical of topographic controls in mountainous environments in Colorado.

\section{Geology}

Consolidated geologic deposits of the Upper Black Squirrel Creek Basin in ascending stratigraphic order include the Cretaceous Pierre Shale, Fox Hills Sandstone, Laramie, and Arapahoe Formations, Cretaceous and Tertiary Denver Formation, and the Dawson Arkose, all of which are important aquifers (Buckles and Watts, 1988). The main water-bearing formations (Fox Hills Sandstone, Laramie, Arapahoe, Denver Formations, and Dawson Arkose) generally dip to the north at angles of 10 degrees or less. Maximum combined thickness of these formations is about $520 \mathrm{~m}$ at the northern boundary of the primary aquifer (Watts, 1995).

Unconsolidated alluvium and aeolian deposits of Quaternary age overlie the slightly dipping sedimentary rocks of Tertiary and Cretaceous age in the Upper Black Squirrel Creek Basin (Banta, 1989). The unconsolidated Quaternary deposits are the primary source of groundwater pumped by irrigation, municipal, and domestic wells in the study area. They consist of modern flood-plain alluvium and Piney Creek alluvium along stream channels; reworked aeolian deposits of sand, silt, and loess; and older valley-fill alluvium. Flood-plain alluvium along stream channels consists of less than $4.5 \mathrm{~m}$ of poorly sorted clay, silt, sand, and gravel. The Piney Creek alluvium of Holocene age ranges in thickness up to $4.5 \mathrm{~m}$ and consists of clayey and sandy silt and silty sand. In some areas, the Piney Creek alluvium overlies aeolian deposits and, in other areas, overlies valley-fill alluvium. The aeolian deposits of Holocene age range in thickness up to $12 \mathrm{~m}$ and consist of fine to very coarse grained sand (Soister, 1968). The valley-fill alluvium of Pleistocene age ranges in thickness up to about $60 \mathrm{~m}$ and consists of sand and gravel. The consolidated waterbearing siltstones, sandstones, and conglomerates, which intersect the unconsolidated Quaternary deposits and overlie the Pierre Shale, are secondary sources of groundwater in the study area (Watts, 1995).

Quaternary surface geology was mapped by Scott (1974) and Tweto (1979) and later digitized from the original scribe sheets by Topper (2008) and Green (1992), respectively (figs. 7 and 8). The geologic deposits are generally elongate in shape, often following creek drainages, and trend in a north-south to northwest-southeast direction. Geologic classifications were combined into a common naming convention for direct comparison. Classifications were defined as: (1) modern flood plain or Piney Creek deposits, (2) aeolian deposits, or (3) intermediate to late alluvium (Louviers Alluvium, Slocum Alluvium, or Rocky Flats Alluvium). Geologic interpretations by each author were generally similar. Most notably, Scott (1974) mapped the region in greater detail and identified a broader extent of the modern flood plain and Piney Creek deposits along several of the stream channels. Additional differences occurred beyond the study area, but were not part of the current investigation. Intermediate alluvium and aeolian deposits compose the majority of the primary aquifer. Modern flood plain or Piney Creek deposits were deposited mainly along the stream channels and near the northwest aquifer boundary.

Soils distributed over geologic deposits were mapped by the Natural Resources Conservation Service (Natural Resources Conservation Service, variously dated) at about a 1:24,000 scale (figs. 9-14). Soil Survey Geographic database (SSURGO) refers to digital soils data produced and distributed by the Natural Resources Conservation Service (NRCS). The fundamental graphic feature in SSURGO is the map unit. Most SSURGO map units are represented as a single soil type for a given classification, but in some cases up to three soil types are represented in each map unit. Each soil type can have up to six layers (soil horizons), so an average attribute value was computed for each map unit where applicable. Weighted-average values associated to the soil types were computed by weighting each horizon value according to thickness and percent composition in the map unit (Wieczorek, 2014). A primary classification in soil taxonomy is soil order, which distinguishes major soil properties (Natural Resources Conservation Service, 2014). Soil orders can be further partitioned into lower-tier soil groups, families, and series, respectively, which introduce additional elements based on climate, environment, and local conditions (Natural Resources Conservation Service, 2014). 


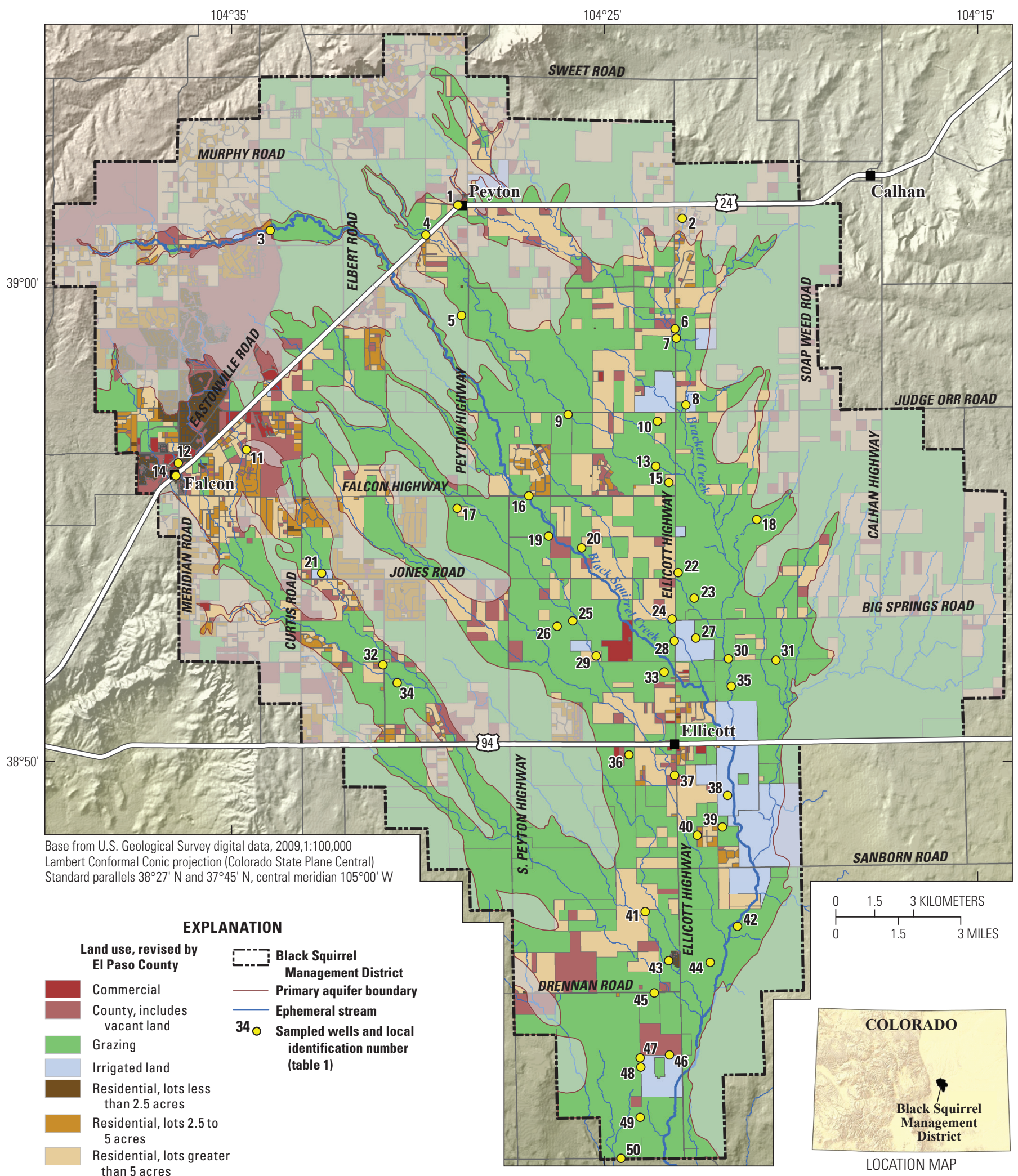

Figure 4. Land use in the Upper Black Squirrel Creek Basin, El Paso County, Colorado (Assessor Office, El Paso County, Colorado, (http://adm.elpasoco.com/InformationTechnologies/GeographicInformationSystems). 


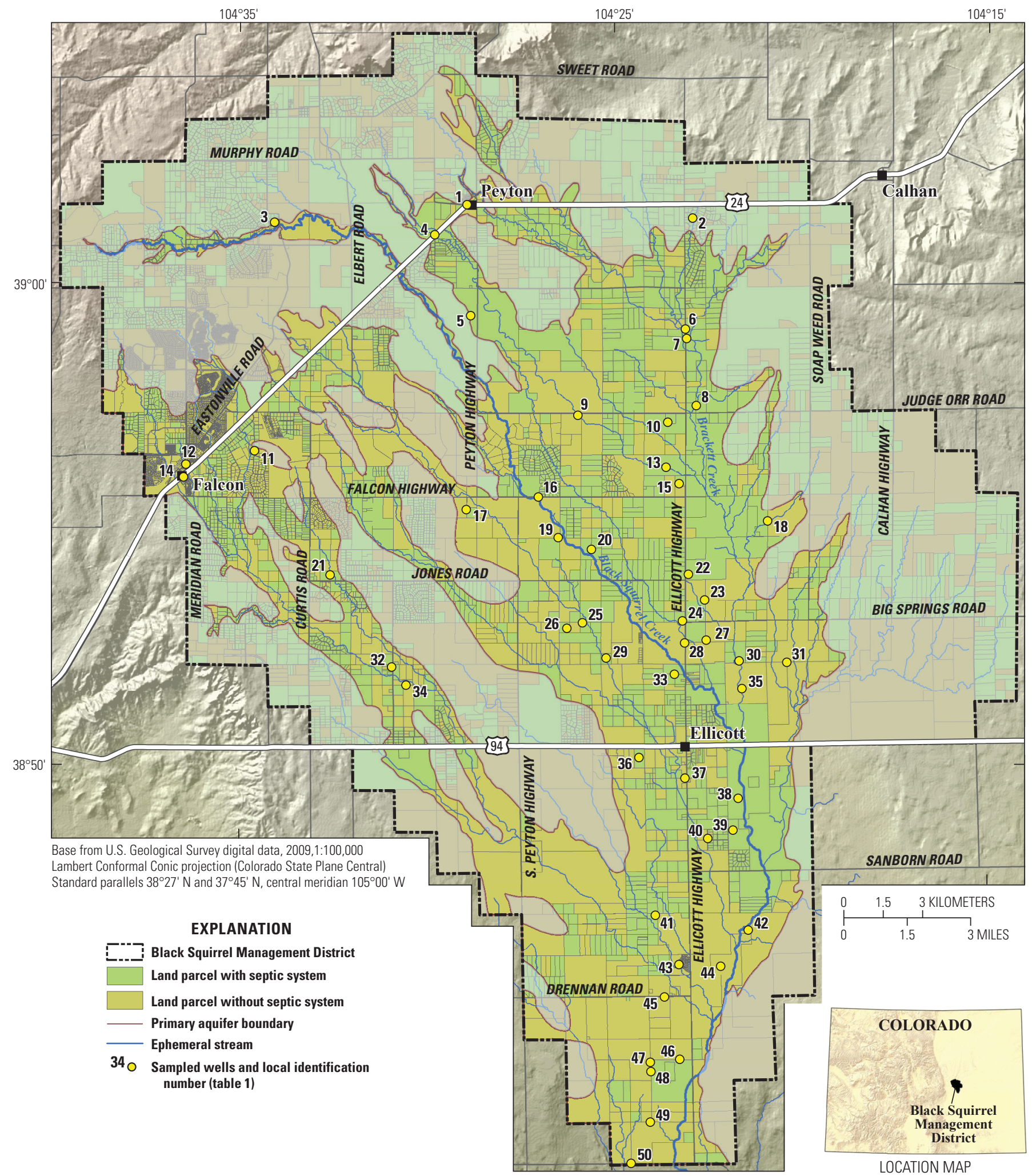

Figure 5. Domestic septic systems in the Upper Black Squirrel Creek Basin, El Paso County, Colorado (http://adm.elpasoco.com/ InformationTechnologies/GeographicInformationSystems). 


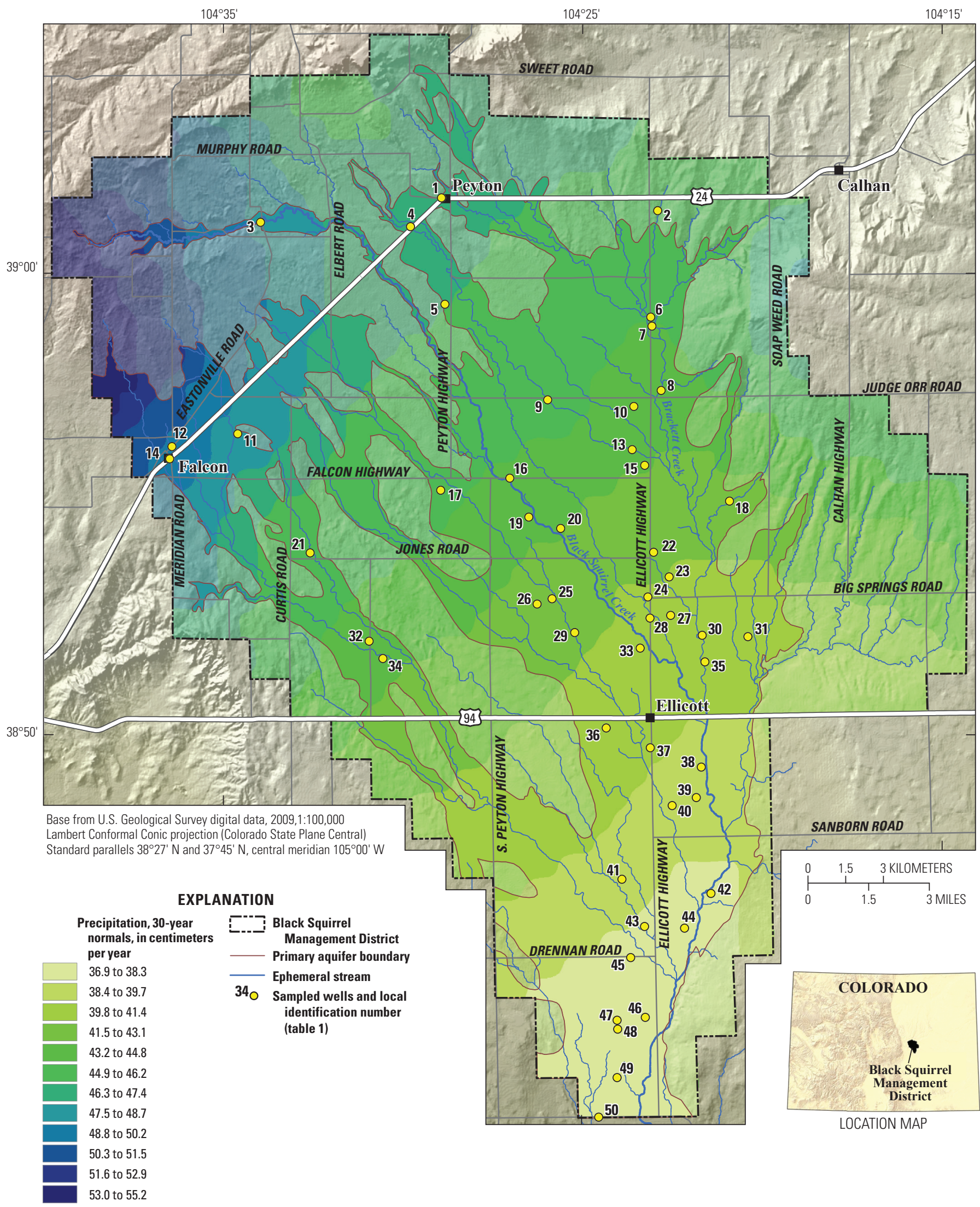

Figure 6. Average yearly precipitation from Parameter-Elevation Regressions on Independent Slopes Model (PRISM) 30-year normals from 1981 to 2010, Upper Black Squirrel Creek Basin, El Paso County, Colorado. 


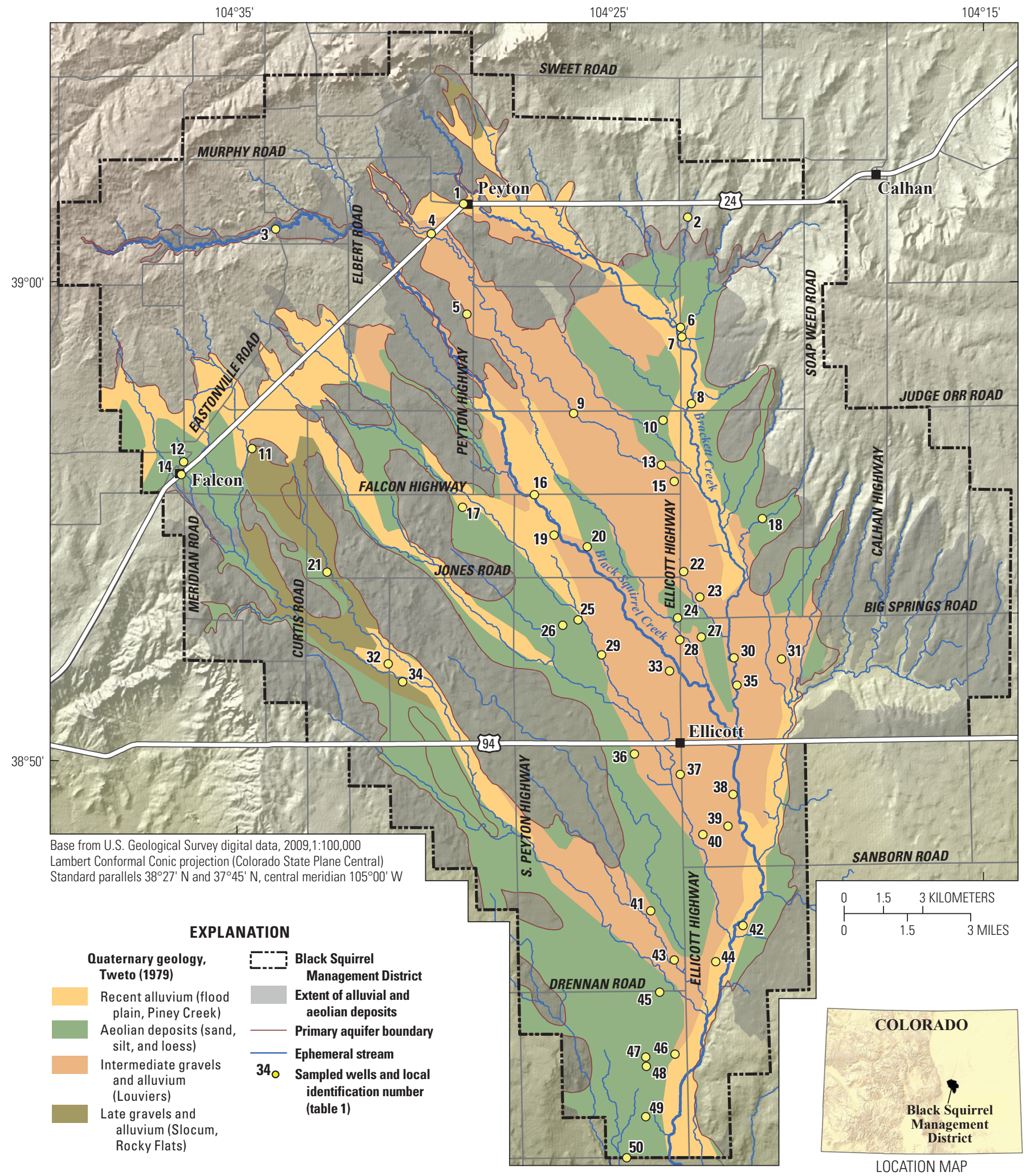

Figure 7. Unconsolidated Quaternary deposits within the primary aquifer from Tweto (1979), Upper Black Squirrel Creek Basin, El Paso County, Colorado. 


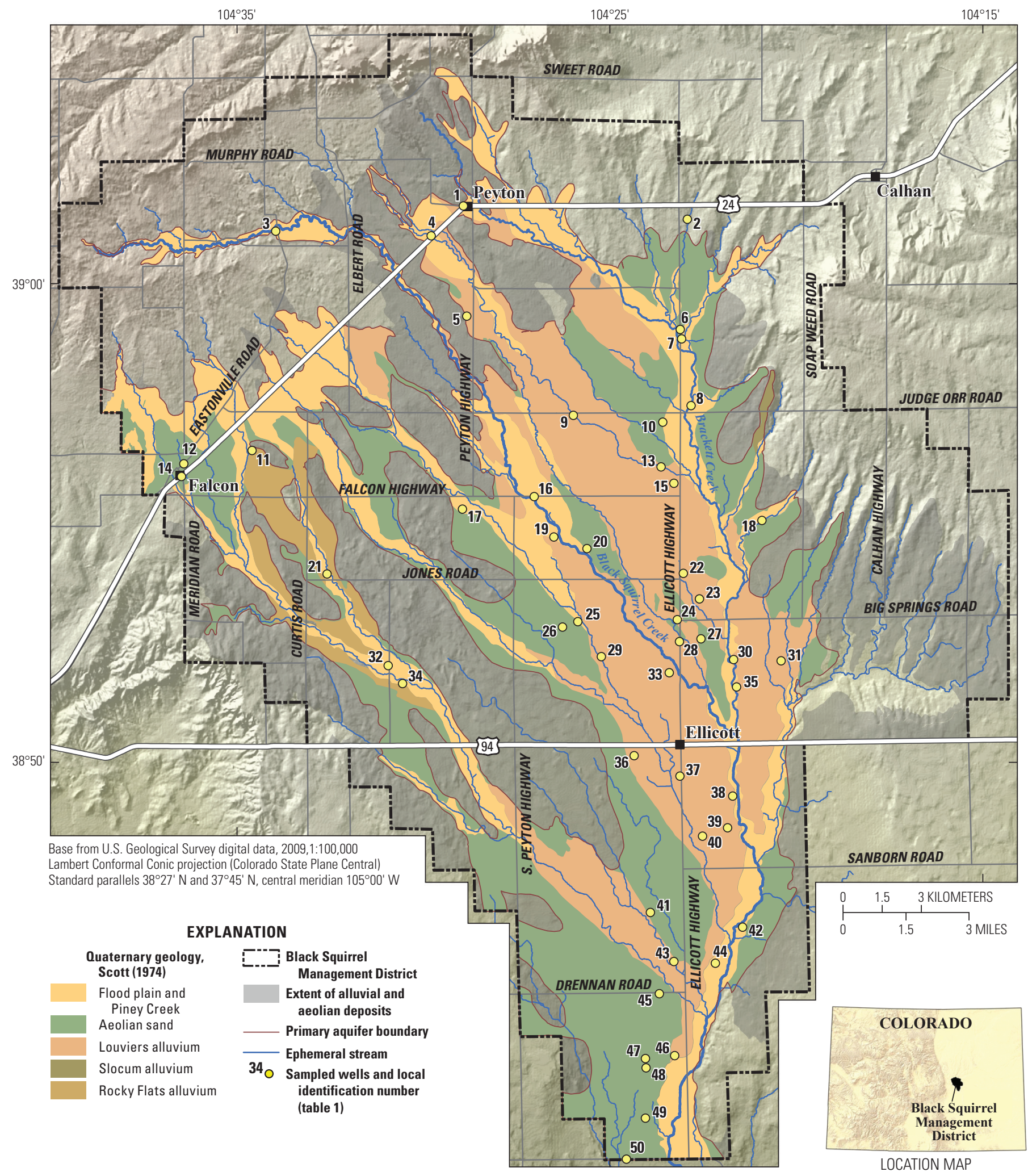

Figure 8. Unconsolidated Quaternary deposits within the primary aquifer from Scott (1974), Upper Black Squirrel Creek Basin, El Paso County, Colorado. 


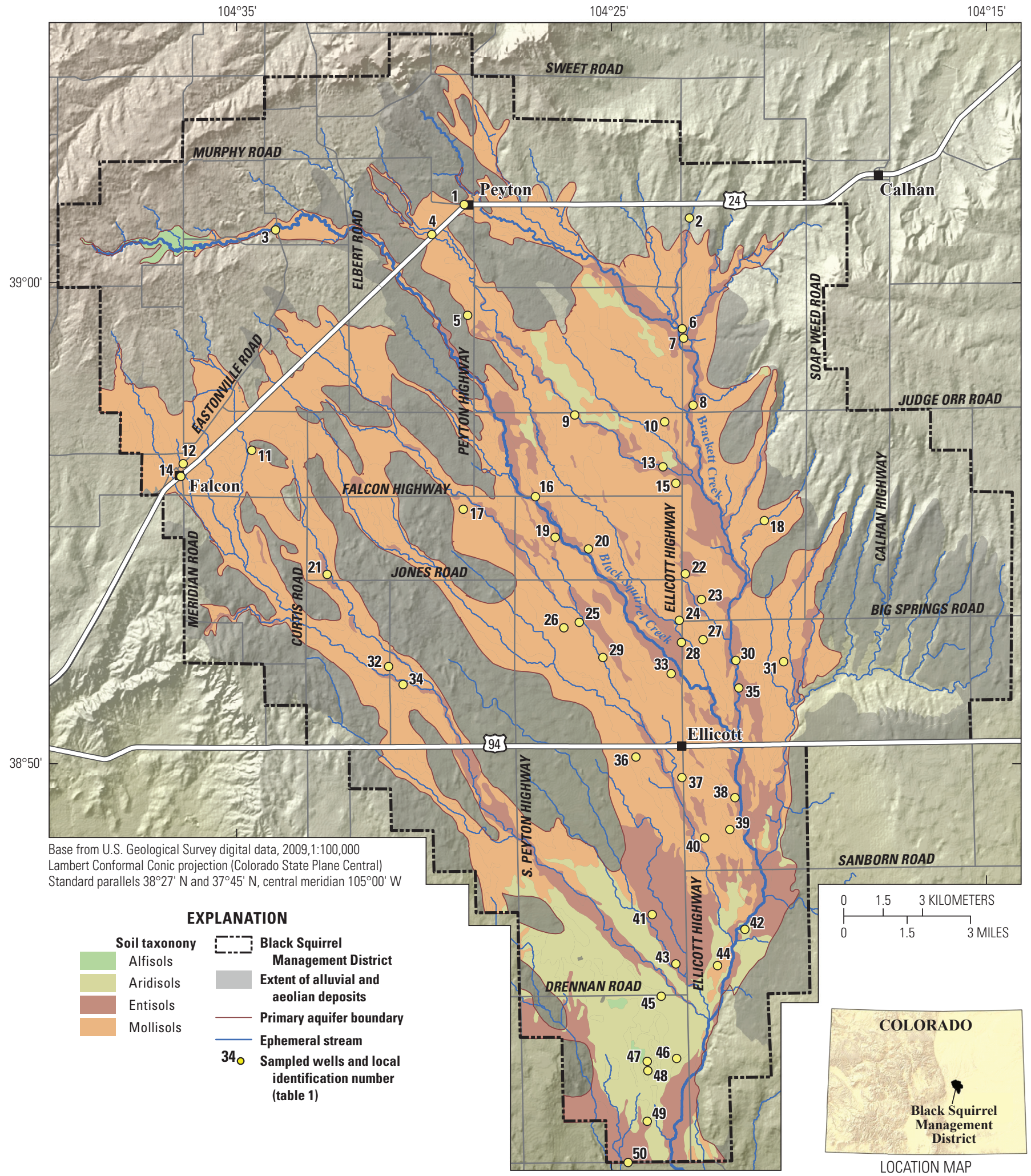

Figure 9. Soil taxonomy (order) overlying the primary aquifer, Upper Black Squirrel Creek Basin, Colorado. Natural Resources Conservation Service (2014) 


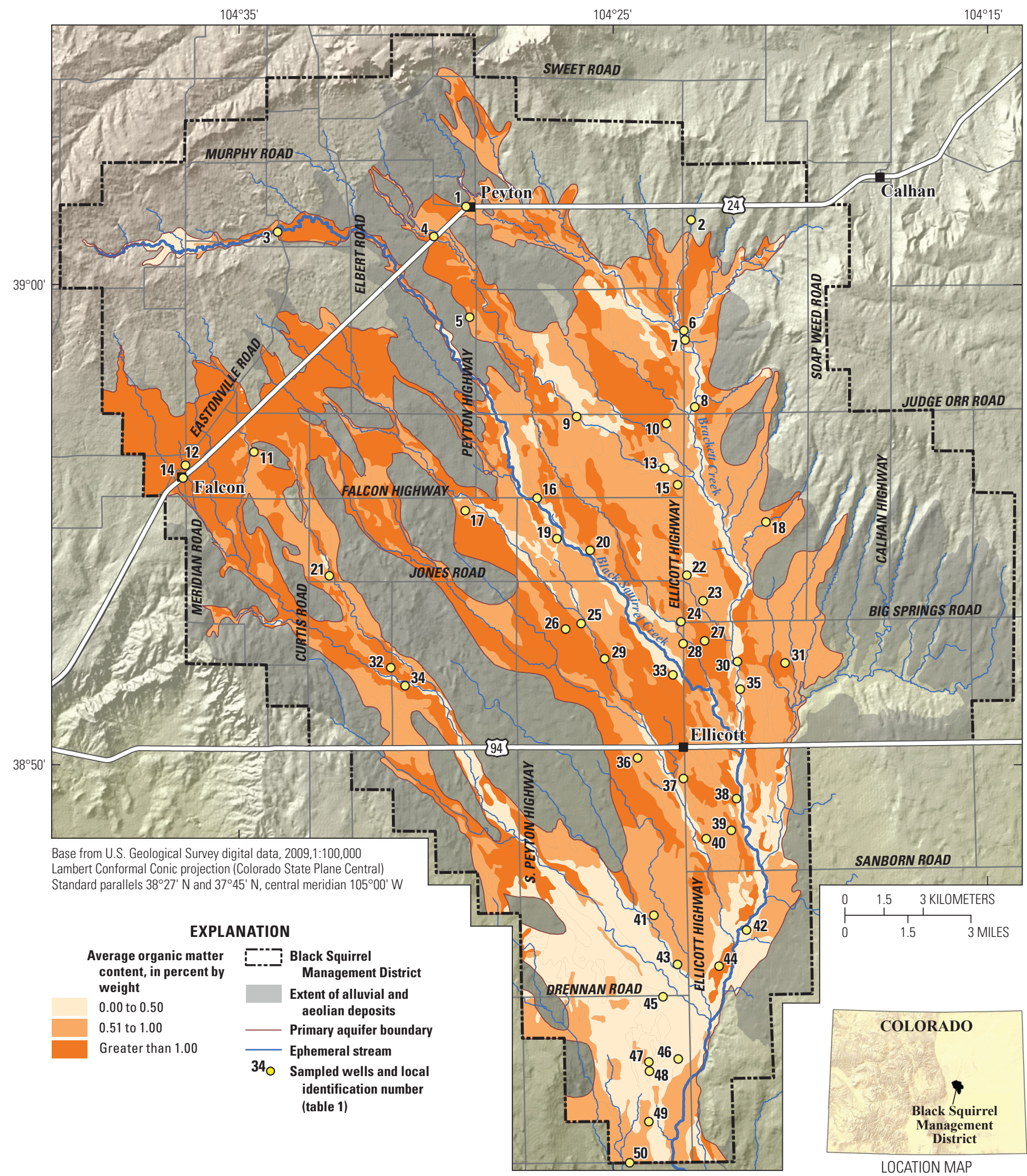

Figure 10. Soil organic matter overlying the primary aquifer, Upper Black Squirrel Creek Basin, Colorado. Natural Resources Conservation Service (2014). 


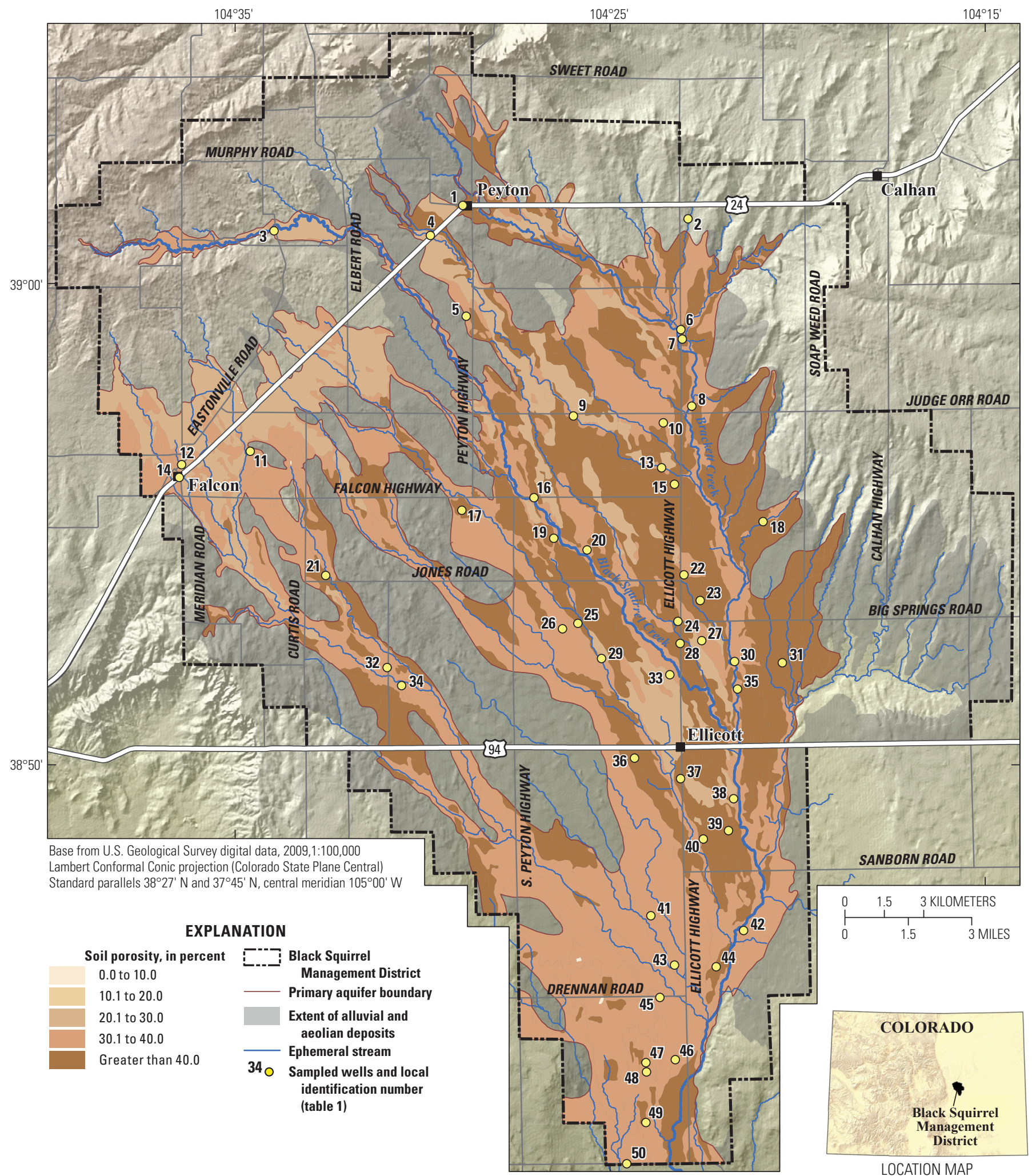

Figure 11. Soil porosity overlying the primary aquifer, Upper Black Squirrel Creek Basin, Colorado. Natural Resources Conservation Service (2014). 


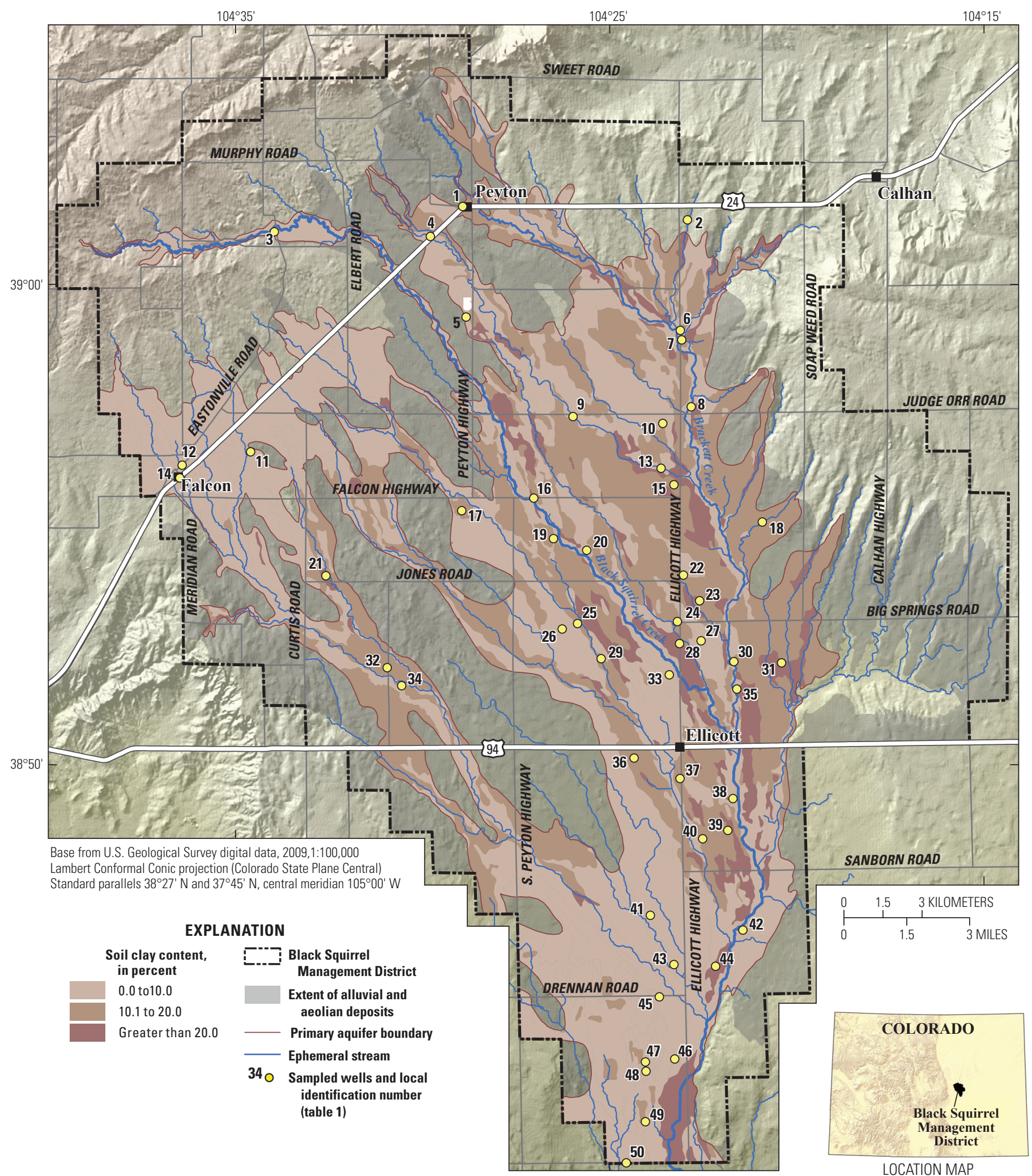

Figure 12. Soil clay content overlying the primary aquifer, Upper Black Squirrel Creek Basin, Colorado. Natural Resources Conservation Service (2014). 


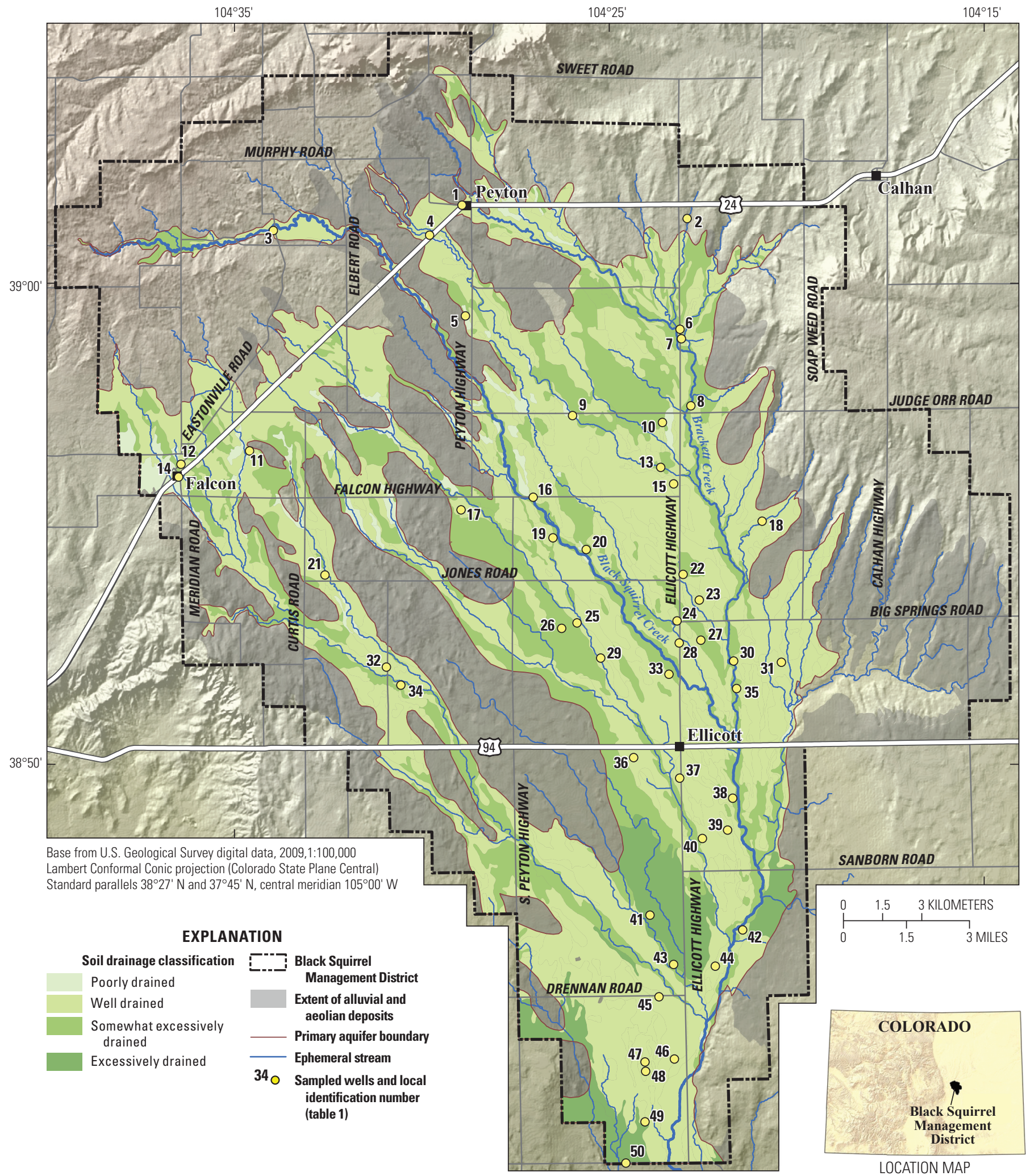

Figure 13. Soil drainage classification overlying the primary aquifer, Upper Black Squirrel Creek Basin, Colorado. Natural Resources Conservation Service (2014). 


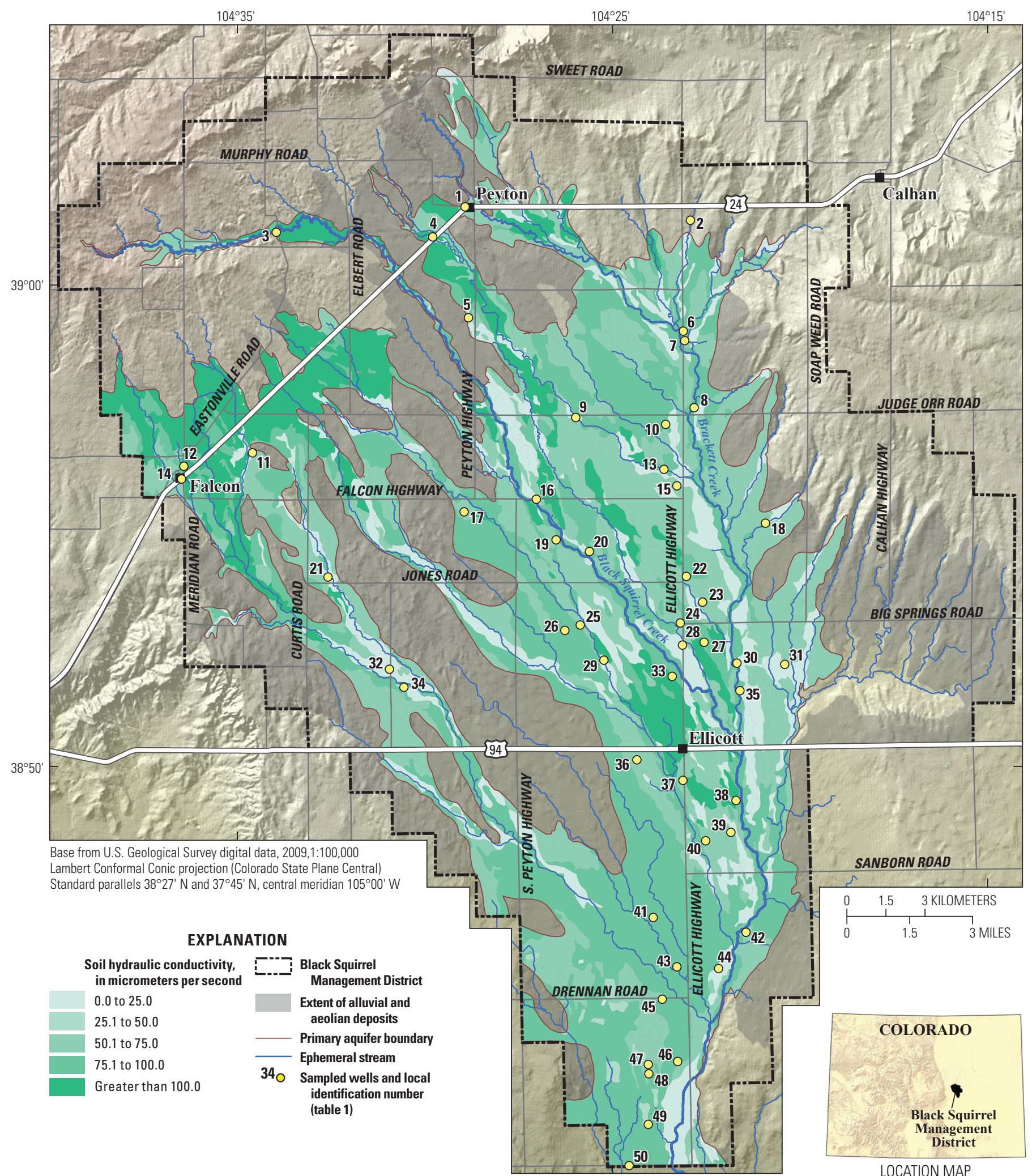

Figure 14. Soil saturated hydraulic conductivity overlying the primary aquifer, Upper Black Squirrel Creek Basin, Colorado. Natural Resources Conservation Service (2014). 
Soils can have a major effect on the rate and characteristic conditions that control how chemical constituents reach the underlying aquifer. As a general overview, major soil orders overlying the primary aquifer are alfisols, aridisols, entisols, and mollisols (fig. 9). The main soil order is a mollisol, which form in semiarid to semihumid areas, typically under a grassland cover, and are characterized by a thick, dark surface horizon with organic materials derived from plant roots (Soil Survey Staff, 1999). The second most abundant soil is an entisol, which has no diagnostic horizons and is generally unaltered parent material, such as unconsolidated sediment or rock. Remaining soils (aridisols and alfisols) are minor in spatial distribution and occur mainly to the south and in small isolated areas to the north. Aridisols are desert soils that have low organic content and are often sparsely vegetated. Alfisols can form under grassland and prairie vegetation and usually possess higher levels of organic matter than either aridisols or entisols. Variations in average organic matter are related to soil order with values ranging up to greater than 1 percent by weight (fig. 10). Soil organic matter is highest in the mollisol soil in the western half of the study area, and is concentrated along stream channels trending in a northwest-southeast direction (fig. 10). Soil porosity ranges from 10 to greater than 40 percent (fig. 11). Areas with highest soil porosity are concentrated in the central part of the study area and to a lesser degree along stream channels to the northwest. Soil clay content is an important factor controlling infiltration, commonly ranging from a few percent to more than 20 percent by weight (fig. 12). Soils can possess greater porosity because of greater clay content, but also have lower permeability to water movement under saturated conditions. Areas with moderate to high clay content are typically located in the central part of the study area, while areas with the highest clay components are usually located within $1 \mathrm{~km}$ of stream channels. The soil is classified as generally well drained to excessively drained (fig. 13), although wetlands are present in small isolated areas. The majority of excessively drained soils reside in the southern part of the study area with somewhat excessively drained soils trending along a northwest-southeast direction, mainly near stream channels to the west. Saturated infiltration rates for downward movement of water are a function of saturated hydraulic conductivity of the soil. Areas with highest saturated hydraulic conductivity are located along the northwest tip of the study area (fig. 14). High conductivity soils have the potential for enhanced recharge during periods of heavy precipitation. Available water storage is a measure of the potential pore water within the soil that may be used by plants. Available water storage is related to the amount of in situ pore water that could interact with constituents introduced at or near the land surface. In the upper 0-25-cm soil depth, available water storage measured in centimeters of water ranges up to $4.6 \mathrm{~cm}$, which constitutes up to 20 percent of the soil pore volume (fig. 15). Areas with moderate to high available water storage occur in pockets mainly along the eastern flank of the study area and in isolated areas to the north and west. In all, several variables control the amount of water capable of being retained in the soil.

\section{Hydrology}

Black Squirrel Creek is ephemeral and a tributary to Chico Creek located south of the study area. Chico Creek is tributary to the Arkansas River (fig. 1). Streambeds are composed primarily of sand, which allows for rapid infiltration of water. Dry conditions persist during most times of the year. Focused runoff generally infiltrates into the sandy streambeds and directly recharges the primary aquifer. Occasionally, after intense precipitation, the available water exceeds infiltration capacity and surface water is discharged from the study area. Infiltration of precipitation and surface water is the main source of recharge to the groundwater and represents about 93 percent of total recharge (Watts, 1995).

The boundary of the primary aquifer of the Upper Black Squirrel Creek Basin (fig. 1, Primary aquifer boundary) was determined from the geographic extent of saturated unconsolidated alluvial and aeolian deposits (Topper and Horn, 2011) (fig. 16). Thicknesses of the unconsolidated deposits range from a few meters along the aquifer perimeter, particularly in the northern areas, to substantially thicker sections in the central part of the aquifer oriented in a north-south direction; the thickest sections are an estimated $66 \mathrm{~m}$ in the study area.

Regional groundwater flow is topographically controlled moving from high to low elevations, but is locally variable. Natural recharge is from deep percolation of precipitation and infiltration of streamflow. Return flow discharged to the aquifer comes from irrigation water in the central part of the aquifer and from treated wastewater at the southern end of the Upper Black Squirrel Management District. Estimated rates of recharge vary between 0 and $20 \mathrm{~cm} / \mathrm{yr}$; rates are typically larger in the northern part of the study area than in the southern part (Watts, 1995). Discharge from the aquifer occurs from evapotranspiration and groundwater outflow. In the northern part of the study area there is surface runoff from upland areas and upward flow from the underlying bedrock aquifers into the primary aquifer may occur at some locations. Upward flow from the bedrock aquifers was estimated at about 7 percent of total recharge (Watts, 1995). In contrast, in the southern part of the study area, infiltration of surface runoff is infrequent and downward movement of groundwater to the underlying geologic formations is possible (Watts, 1995).

The primary aquifer serves an important role in local and regional water use. Pumping from wells for domestic, stock, agricultural, and municipal use is administered by Colorado Division of Water Resources. Water reserved for municipal use is exported west of the basin to Colorado 


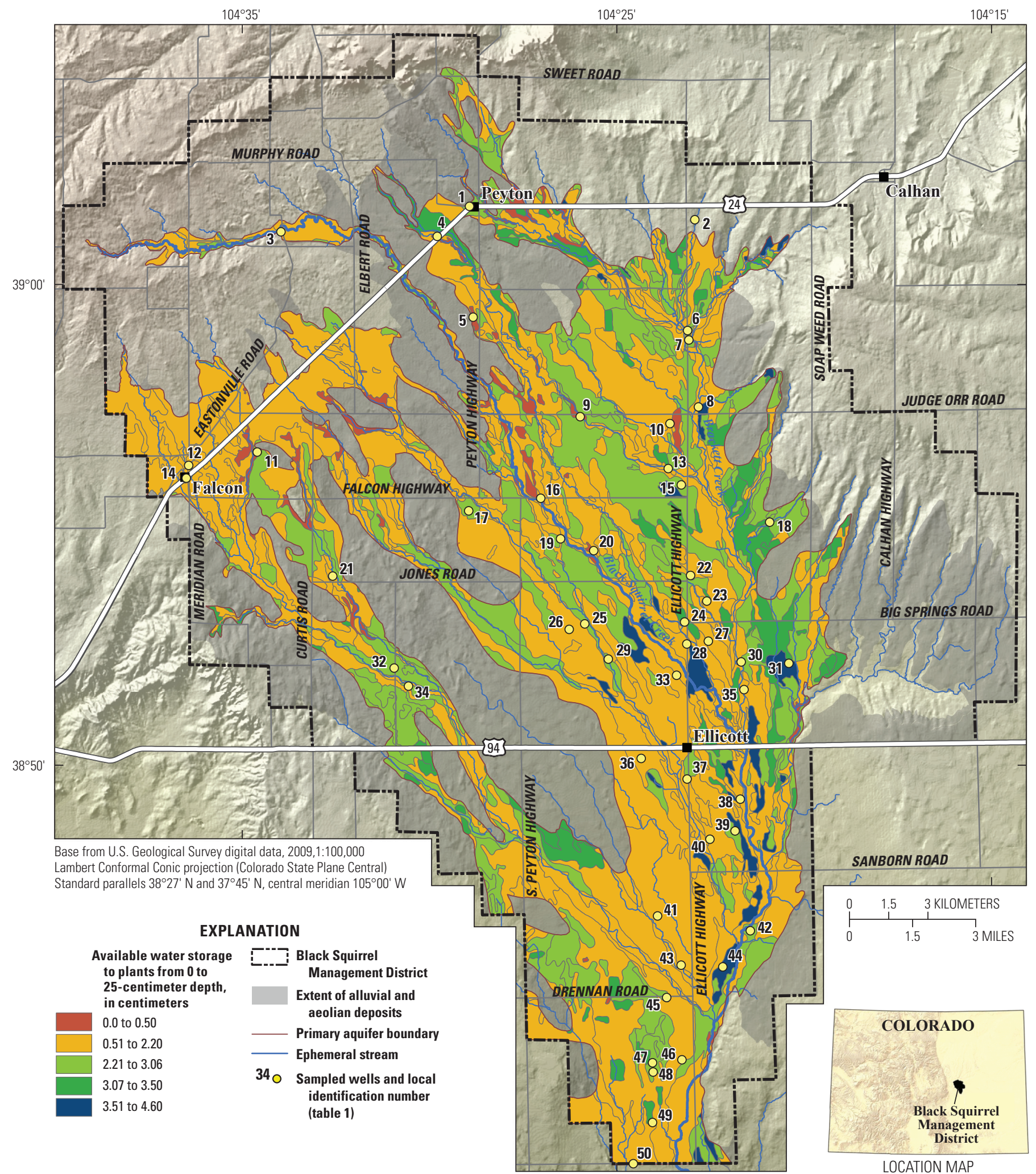

Figure 15. Soil available water storage to 25-centimeter depth overlying the primary aquifer, Upper Black Squirrel Creek Basin, Colorado. Natural Resources Conservation Service (2014). 


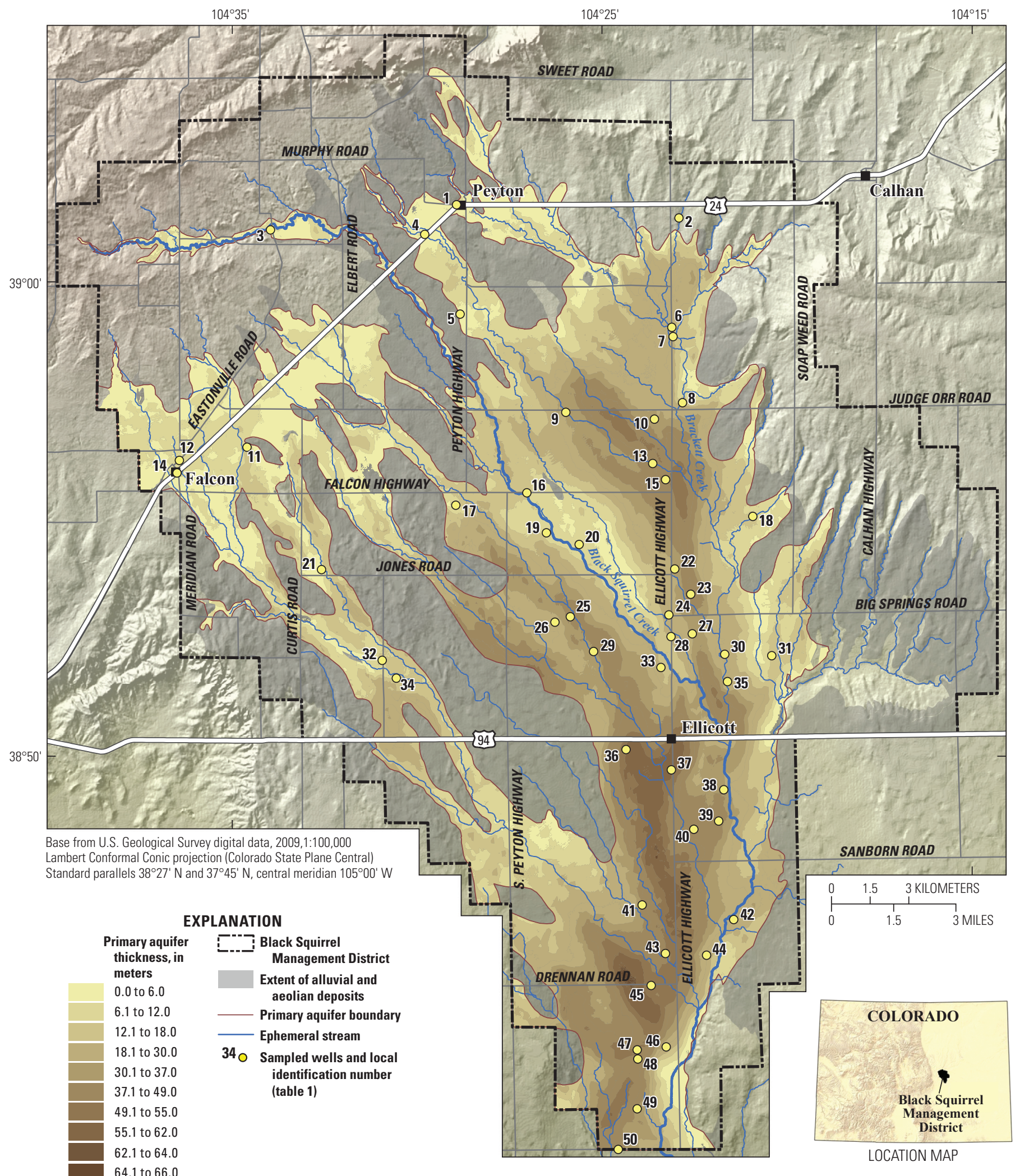

Figure 16. Estimated thicknesses of unconsolidated deposits of the primary aquifer from Topper and Horn (2011), Upper Black Squirrel Creek Basin, Colorado. 
Springs. The remaining water serves locations within the basin. Yields from wells generally ranged from about 10 gallons per minute ( $\mathrm{gal} / \mathrm{min}$ ) for stock and domestic wells to $1,500 \mathrm{gal} / \mathrm{min}$ for irrigation and municipal wells (Buckles and Watts, 1988).

Prior to the 1950s, more areas of the aquifer had shallow groundwater in comparison to later decades. Prior to development and extensive use of irrigation wells in the area during the 1950s and 1960s, saturated thicknesses of the unconsolidated deposits were more than $35 \mathrm{~m}$ (McGovern and Jenkins, 1966; Bingham and Klein, 1974). By the mid-1980s, saturated thicknesses of the unconsolidated deposits had declined; thicknesses were more than $35 \mathrm{~m}$ in only one area near the southern boundary of the study area (Buckles and Watts, 1988). As water-table elevations declined the spatial footprint of the aquifer decreased, particularly in thinly saturated areas (Watts, 1995). Lowered water-table elevations have caused wells near the boundaries of the aquifer to run dry. Areas with shallow groundwater are beneficial in providing a suitable environment for vegetation that is limited by short rooting depths or large water requirements. In areas where pumping has caused the water table to decline more than $3 \mathrm{~m}$ below land surface, evapotranspiration through the soil, native vegetation, and invasive phreatophytes has decreased, substantially altering the local hydroecologic cycle (McGovern and Jenkins, 1966). Moreover, because the alluvial and underlying bedrock aquifers are thought to be hydraulically connected, development of the underlying bedrock aquifers could have an adverse effect on water supplies in the primary aquifer (Buckles and Watts, 1988; Watts, 1995).

\section{Methods of Investigation}

Groundwater samples collected from 50 wells were analyzed for field characteristics, major ions, nutrients, tritium, chlorofluorocarbons (CFCs), dissolved gases, and fuel products. A total of 42 existing wells completed in the primary aquifer were selected for geochemical sampling. Given restrictions in site accessibility and limited well coverage, 8 new monitoring wells were installed to fill data gaps. Installation of the 8 monitoring wells was managed by the Groundwater Quality Study Committee of El Paso County. Drilling of the monitoring wells was performed by a private contract driller. USGS requested that the drillers develop the wells according to USGS standards but did not have authoritative control over the drilling component of the project.

Several analyses were conducted to characterize groundwater quality and effects to groundwater quality. Areas where agriculture may have affected groundwater quality were determined using remote sensing imagery, groundwater levels, and groundwater flow directions. Major ion data were used to characterize the geochemical conditions of groundwater and differentiate water types. Analysis of nutrient data was aimed on nitrate; a main constituent of interest in the study area. Several baseline calculations were performed to identify factors controlling nitrate levels and to interpret mechanisms controlling nitrate variability in the primary aquifer. Tritium, $\mathrm{CFC}$, and dissolved gas data were analyzed to determine groundwater ages and differentiate sources of recharge to the primary aquifer. Fuel component data (including acetone, benzene, diisopropyl ether, ethylbenzene, methyl acetate, methyl tertiary butyl ether (MTBE), methyl tert-pentyl ether, m- + p-xylene, o-xylene, tert-amyl alcohol, tert-butyl alcohol, tert-butyl ethyl ether, and toluene) established concentrations of fuel-related byproducts as a baseline before substantial oil and gas exploration activities begin. In the final stage of analyses, aquifer susceptibility and aquifer vulnerability to nitrate in groundwater were examined using probability maps derived from logistic regression.

\section{Groundwater-Level Analyses}

Historical depths to groundwater were evaluated using observations from 172 wells screened in the primary aquifer (Appendix 1, tables 1-1 to 1-4; USGS National Water Information System [NWIS], http://dx.doi.org/10.5066/ F7P55KJN). Average and median depths to groundwater from land surface were determined from 1975 to 2015 . The irregular data coverage prevented a direct evaluation of depth to groundwater across the aquifer using consistently measured sites. As an approximation, depths to groundwater were evaluated over 5-year periods. Over the four decades of record, only 12 wells in the central part of the aquifer had at least one measured groundwater level per 5-year period examined. The 5 -year periods were based on water years; a water year is the 12-month period October 1 through September 30 designated by the calendar year in which it ends. Where applicable, 5-year periods $(1975,1980,1985,1990,1995,2000,2005$, and 2010) represented 2.5 years prior to and following the label year, while 2015 represented only prior data.

Median water-table elevations and groundwater flow directions in the primary aquifer were determined in ArcGIS using observations from 83 wells recorded during 2000-2013 (Appendix 1, tables 1-5 to 1-6; USGS NWIS, http://dx.doi.org/10.5066/F7P55KJN). The period of 2000-13 was chosen because depth to groundwater declined relatively little since about 2000 when averaged over 5 -year periods and because the terminal year, 2013, corresponded to this investigation. Cokriging was used to interpolate depth to groundwater with two secondary variables - aquifer thickness and distance to streams. Water-table elevations were determined using land surface elevation and subtracting the depth to water estimates at each raster grid cell. All wells were considered water-table wells because the primary aquifer is unconfined (Watts, 1995). Raster cells resistant to interpolation along small portions of the study area boundary, particularly in the northern section with thin sediment deposits were assigned a depth to groundwater of $1 \mathrm{~m}$. A spline with barriers interpolation was used as a polishing step 
for the contouring by resampling the kriging estimates so that water-table contours were approximately perpendicular to the irregular aquifer boundaries. Local groundwater flow directions were approximated at select sample locations using the raster-based flow direction tool in ArcGIS (accessed November 13, 2014, at http://webhelp.esri.com/arcgisdesktop/9.2/ index.cfm?TopicName=flow_direction). The tool evaluated differences in water-table elevations over the eight surrounding raster grid cells to determine flow directions to the nearest 45 degrees using a grid resolution of $250 \mathrm{~m}$ (1 of 8 flow directions in 360 degrees). The results provide a coarse representation of groundwater flow directions useful in understanding the basic linkages between flow patterns and groundwater quality and groundwater age. A groundwater model would be a logical next step to characterize aquifer dynamics and spatial variability of water-table elevations in greater detail.

An agricultural region was determined from crop areas identified from land satellite imagery registered for 1999 , 2006, and 2014 in Google Earth. Crop areas identified primarily from irrigation pivots were visually inspected based on the resolution of the patterns. Crops clearly visible in the 2014 Landsat image were given a "recent" classification. Remaining crops identified in the 1999 or 2006 Landsat images were given either a "primary historic" classification if clearly visible or a "secondary historic" classification if crop patterns were muted. Although classifications were useful to examine variations in crop locations through time, all crop areas were used without preference when defining the agricultural region given the subjectivity of the rating. "Farmland" was defined as regions where $500 \mathrm{~m}$ buffers were placed around the crop fields to account for spatial uncertainty and local mixing of groundwater. To define the agricultural region, region boundaries were first traced around farmland (buffered crop areas). Straight line connections between farmland were manually located using water-table elevations and groundwater flow paths as guides. This procedure was used to approximate the spatial extent of an agricultural region where nitrogen from fertilizers may have reached the water table and was transported through the aquifer. The defined agricultural region encompassed the majority of parcels currently (2013-2014) identified as irrigated parcels by El Paso County or land once used for agriculture.

\section{Groundwater-Quality Sampling}

Sampling sites were selected using a stratified random sampling within cells technique (Scott, 1990). The random sampling within cells program first defined a population of potential sites in the study area that were equally spaced about 1,600 $\mathrm{m}$ apart. The random sampling within cells program divided the area within the primary aquifer boundary into 55 equal-area polygons independent of land use. Field personnel then located existing wells within a 1,600 m radius of the randomly selected primary sites. If a well was not located near the primary site, then wells were located at an alternate site.
Selection criteria included ensuring that each well could be sampled upstream from any water treatment devices such as water filters or chlorinators. A total of 42 existing wells were located and accessible for sampling. An additional 8 monitoring wells were installed by contract drillers during April and May 2013 to fill existing data gaps, which completed the set of 50 wells (fig. 17). The set of 50 wells is used for public supply, domestic use, stock supply, monitoring, and irrigation, and may serve multiple purposes. Site information for the 50 sampled wells is provided in table 1. The distribution of wells was statistically representative of the primary aquifer when considering areal proportions; however, all land use types, most notably small areas of residential lots under 2.5 acres and commercial land, were under sampled by random selection. At each sample location, vertical variations in water quality were not determined; although, it is known the groundwater will be mixed in many locations from pumping of public supply, domestic, and irrigation wells. Moreover, some of the pumped groundwater used near the land surface for agricultural or human needs eventually returns to the aquifer as recharge causing additional recirculation of water by human activities.

Groundwater-quality samples were collected once from all 50 sites during May and June, 2013 (fig. 18). Samples were collected using procedures described by the USGS National Field Manual (U.S. Geological Survey, variously dated), and the USGS Chlorofluorocarbon Laboratory, Reston, Va. (U.S. Geological Survey, 2007). Water was pumped from domestic and municipal wells using existing pumps, and samples were collected between the wellhead and any pressure tanks, filtering, or treatment devices. Water was pumped from monitoring wells with a submersible electric pump constructed of stainless steel and Teflon. Water samples were processed onsite in a mobile laboratory by using methods designed to minimize changes to the water-sample chemistry. Prior to sample collection, stagnant water was flushed by purging at least three casing volumes from the well. Specific conductance, $\mathrm{pH}$, water temperature, and dissolved oxygen were measured while purging until readings were stable according to the USGS National Field Manual (3 consecutive readings, 5 minutes apart). Once readings stabilized, water samples were collected in precleaned bottles within an enclosed chamber to prevent sample contamination. To prevent degradation of water samples and maintain the initial concentration of constituents between the time of sample collection and laboratory analyses, bottles were preserved according to the requirements of the laboratories. Preservation practices differ among analytes and may include chilling, filtration ( 0.45 micrometer) and chemical treatment (U.S. Geological Survey, variously dated). Sampling equipment was cleaned following the collection of samples using procedures listed in the USGS National Field Manual (U.S. Geological Survey, variously dated).

The collected water samples were analyzed for major ions, nutrients, fuel products, dissolved gases, CFCs, and tritium (tables 2-4). Samples for alkalinity were analyzed in the field by using procedures listed in the USGS National 


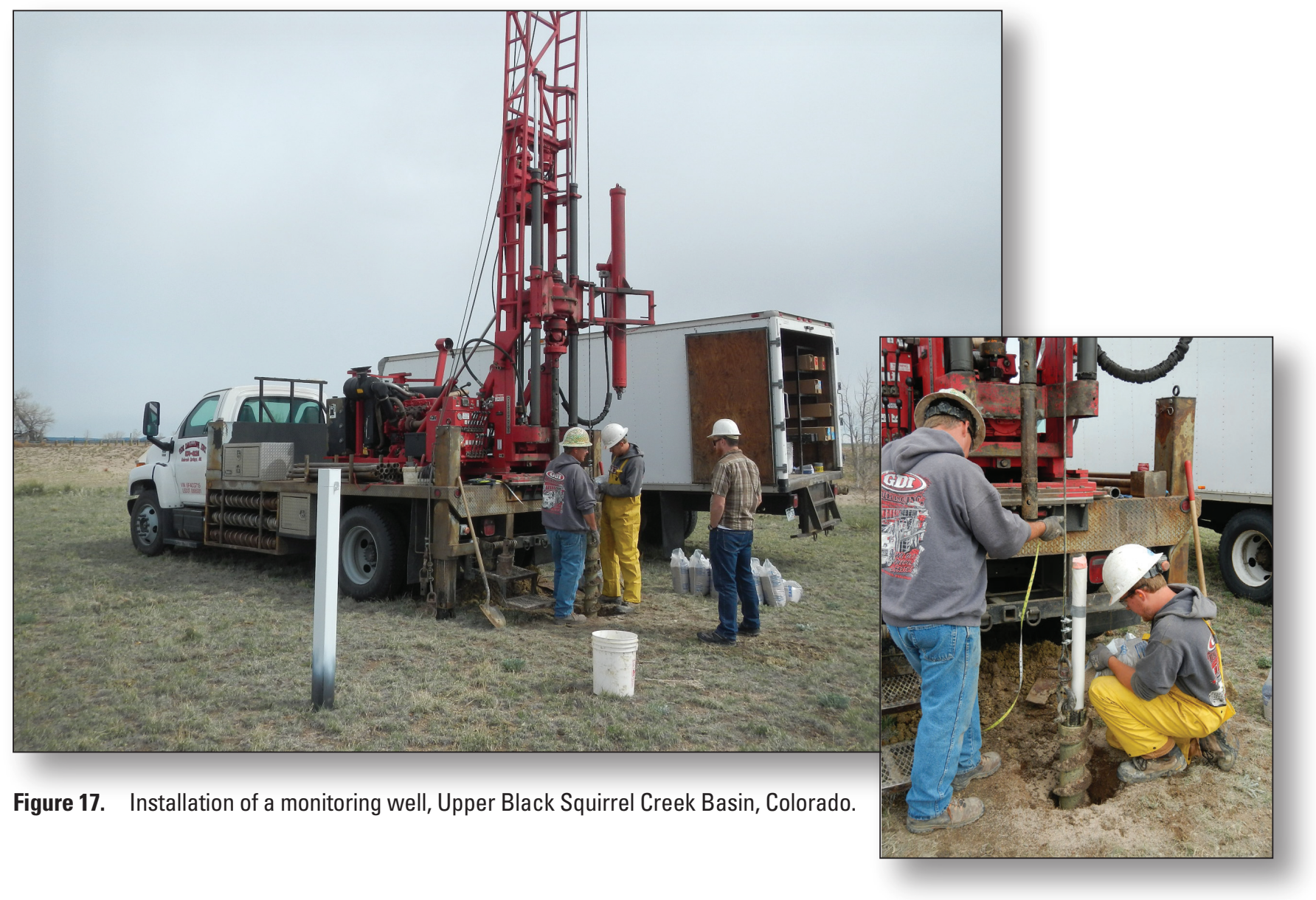

Field Manual (U.S. Geological Survey, variously dated). Samples for major ions, nutrients, and fuel products (including acetone, benzene, diisopropyl ether, ethylbenzene, methyl acetate, methyl tertiary butyl ether (MTBE), methyl tert-pentyl ether, $\mathrm{m}$ - + p-xylene, o-xylene, tert-amyl alcohol, tert-butyl alcohol, tert-butyl ethyl ether, and toluene) were sampled in groundwater from 49 of the 50 wells and analyzed by the USGS National Water Quality Laboratory in Lakewood, Colo. (Fishman, 1993; Fishman and Friedman, 1989) (table 2). Samples for fuel products could not be collected from well 38 during the time of sampling. Tritium levels (activities) were measured at the USGS Tritium Laboratory in Menlo Park, Calif. (table 3). Samples for CFCs and dissolved gases were analyzed by the USGS Chlorofluorocarbon Laboratory in Reston, Va. (Plummer and Busenberg, 1999; U.S. Geological Survey, 2007) (tables 3 and 4).

\section{Quality Assurance and Quality Control}

Replicate samples, equipment blanks, and trip blanks were collected during the investigation as a component of water-quality sampling to evaluate sample variability and to identify potential contamination (tables 5 and 6). Equipment blanks and trip blanks were collected in a directed manner to determine if decontamination of the sampling equipment between sites was adequate and if sample contamination occurred during sample collection, transport, and analysis (table 5). All blank samples were collected using blank water prepared at the USGS National Water-Quality Laboratory that is certified to be free of environmental sample analytes above their reporting levels. Trip blanks were processed using the same procedures and equipment as the environmental samples. Equipment blanks were analyzed for major ions and nutrients. It is not possible to prepare meaningful blank solutions for tritium, dissolved gases, and CFCs, so no blanks for these constituents were collected. Replicate samples were collected at a rate of approximately 1 of every 10 (10 percent) environmental samples collected (table 6). Replicate samples were collected to assess variability caused by the collection and analyses of samples (table 6). All replicates were sequential; the replicate sample was collected after the environmental sample and analyzed using the same method. Replicate analyses were performed for major ions, nutrients, and fuel products. The relative percent difference (RPD) in concentrations between environmental and replicate analyses was compared using the difference between concentrations divided by their average, expressed as a percentage of average. Replicate samples for dissolved gases were collected at each site as part of standard sample collection, so additional dissolved gas replicate samples were not collected. Five replicate samples for $\mathrm{CFC}$ determination were collected at each site as part of standard sample collection. 
Table 1. Selected well identification, coordinate location, depth, and type, depth to groundwater, and land use, Upper Black Squirrel primary aquifer, El Paso County, Colorado, 2013.

[--, no record; NAD 83, North American Datum in 1983]

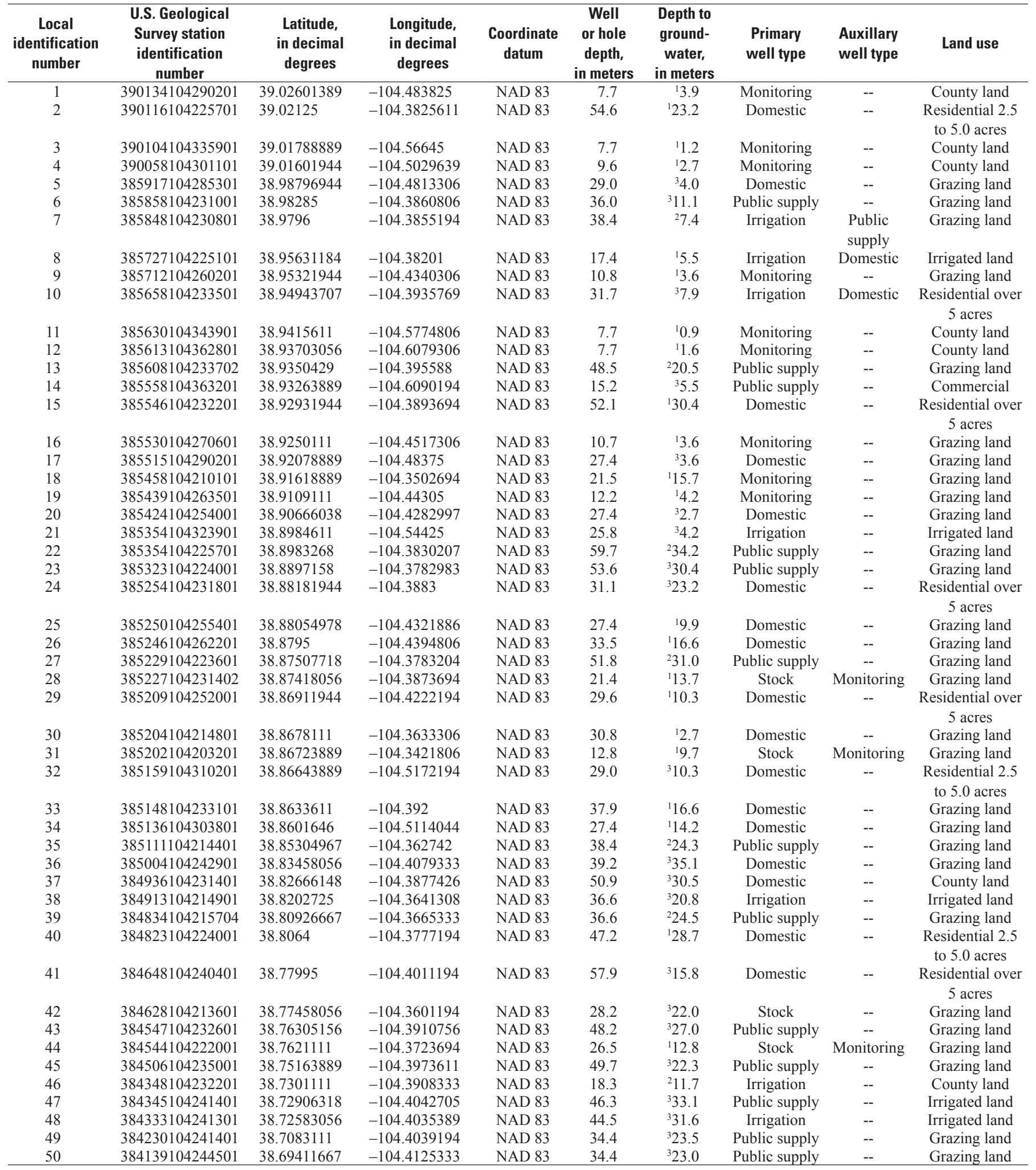

${ }^{1}$ Depth to groundwater measured during present study from May to June 2013.

${ }^{2}$ Depth to groundwater estimated using median depth to water collected between water years 2000-2013.

${ }^{3}$ Depth to groundwater estimated using interpolation of median depth to water in study area. 


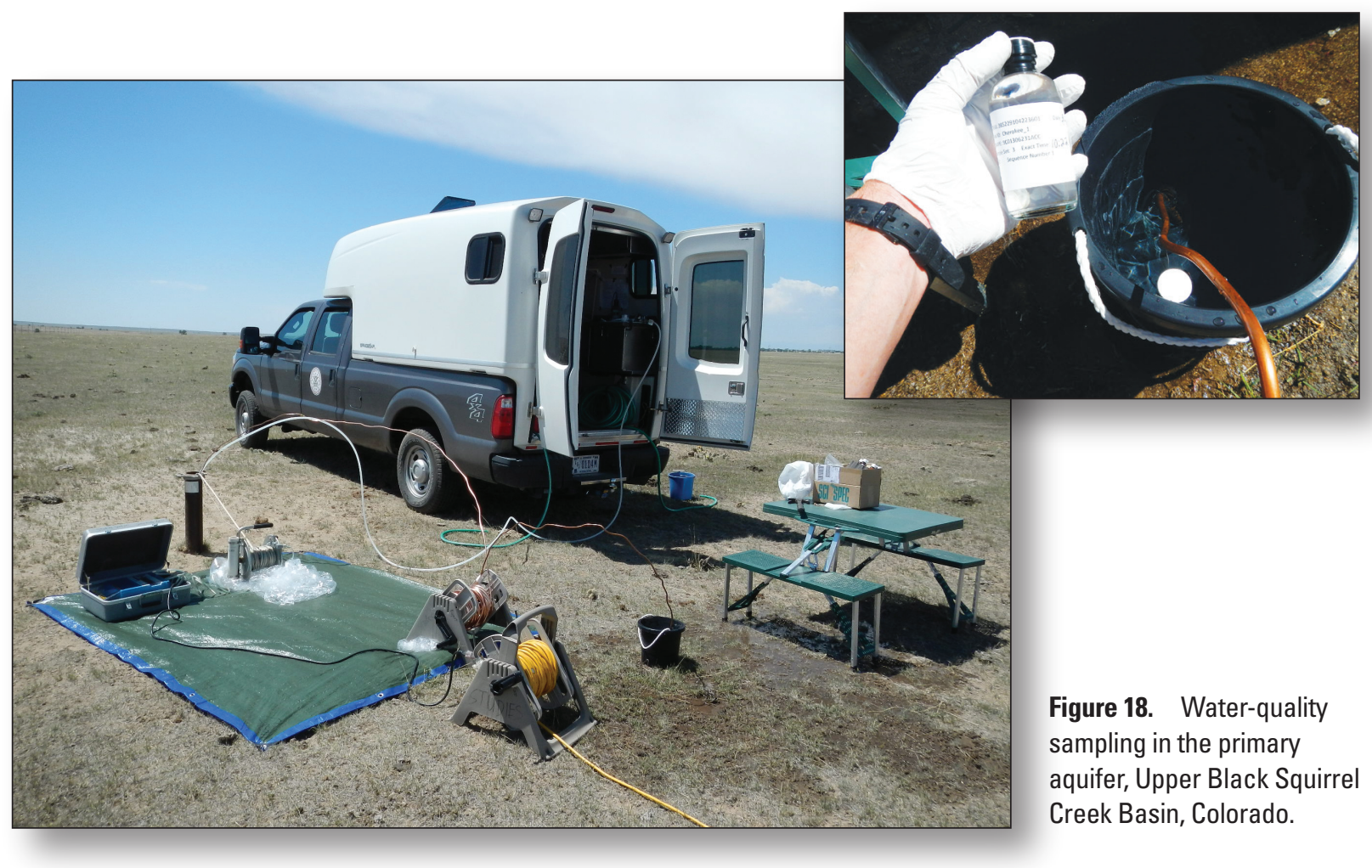

\section{Nitrate Analyses}

Historical nitrate concentrations in the primary aquifer were evaluated over nearly three decades from 1985 to 2013. The dataset consisted of 86 wells screened in the primary aquifer (Appendix 1, tables 1-7 to 1-8; USGS NWIS, http://dx.doi.org/10.5066/F7P55KJN). Data were grouped over 5-year periods based on water years from 1985 to 2015 because of the irregularity of sampling dates, although as clarification the data record ended in 2013 coincident with the current study. Where applicable, 5-year periods (1985, 1990, $1995,2000,2005,2010,2015)$ represented 2.5 years prior to and proceeding the label year, while 2015 represented only prior data. Median nitrate concentrations across the aquifer were considered representative if at least 30 wells were sampled per 5-year period, whereas periods with less data were considered uncertain and were not used in the evaluation. Nitrate concentrations were evaluated statistically using nonparametric correlation coefficients determined from the Kendall Tau-B, Kendall Tau-C, and Spearman rank methods that do not assume a specific data distribution and correlation coefficient determined from the Pearson method using the assumption of normality in the dataset. Nonparametric methods were also used to distinguish nitrate distributions between time periods and to evaluate monotonic trends using KruskalWallis, Mann-Kendall, and seasonal Kendall methods (Helsel and Hirsch, 1992; SYSTAT Software, Inc. 2004). The seasonal Kendall method was performed using quarter divisions on the calendar year.
Nitrate concentrations in groundwater and corresponding classifications of land uses, well use types, soil properties, and geologic deposits at sampling locations were examined to identify potential effects on nitrate. Statistical significance in distinguishing nitrate concentrations by classification were determined using $p$-values produced from nonparametric statistical tests; Mann-Whitney test for two classifications and Kruskal-Wallis test for three or more classifications per category. A $p$-value of 0.10 or below was considered a significant relation for evaluating categorical differences.

To thoroughly examine nitrate transport in the primary aquifer would require numerical modeling to evaluate transport pathways, groundwater discharge and residence times, and calibration methods to match observed nitrate levels and groundwater ages, which was beyond the scope of the investigation. As a first step, estimates of nitrate inputs were determined for regions distinguished by land use under several simplifying assumptions. Mobilization of nitrate and background concentrations of naturally occurring nitrate were not examined directly. A simple two-component mixing model was adopted, which considered (1) subsurface inputs of nitrate transported by the groundwater and (2) near-surface inputs of nitrate from land use. The main assumptions of the mixing model were that nitrate was fully conservative, nitrogen inputs and outputs in each examined region reached steady-state, and groundwater drawn from the aquifer for land use activities returned to the aquifer as recycled water without appreciable losses, which were notable simplifications given the character, timing, and complexity of hydrological processes and spatial distribution of land use in the region. 
Table 2. Selected major-ion, nutrient, and fuel products data from groundwater, Upper Black Squirrel primary aquifer, El Paso County, Colorado, 2013.

[mm, month; dd, day; yyyy, year; E, existing well; M, monitoring well; --, no data; <, less than; $\mathrm{ft}$, feet; >, greater than; $\mu \mathrm{S} / \mathrm{cm}$, microsiemens per centimeter; ${ }^{\circ} \mathrm{C}$, degrees Celsius; $\mathrm{mg} / \mathrm{L}$, milligrams per liter; $\mu \mathrm{g} / \mathrm{L}$, micrograms per liter; $\mathrm{pCi} / \mathrm{L}$, picocuries per liter; $\mathrm{CaCO}_{3}$, calcium carbonate; $\mathrm{N}$, nitrogen; $\mathrm{P}$, phosphorous; R, radchem non-detect, below Sample Specific Critical Level (ssLc); m-, meta; o-, ortha; p-, pera; NAD 83, North American Datum of 1983; shaded areas indicate concentrations that exceed U.S. Environmental Agency National Primary (dark gray) or Secondary Drinking Water Standards (light gray)]

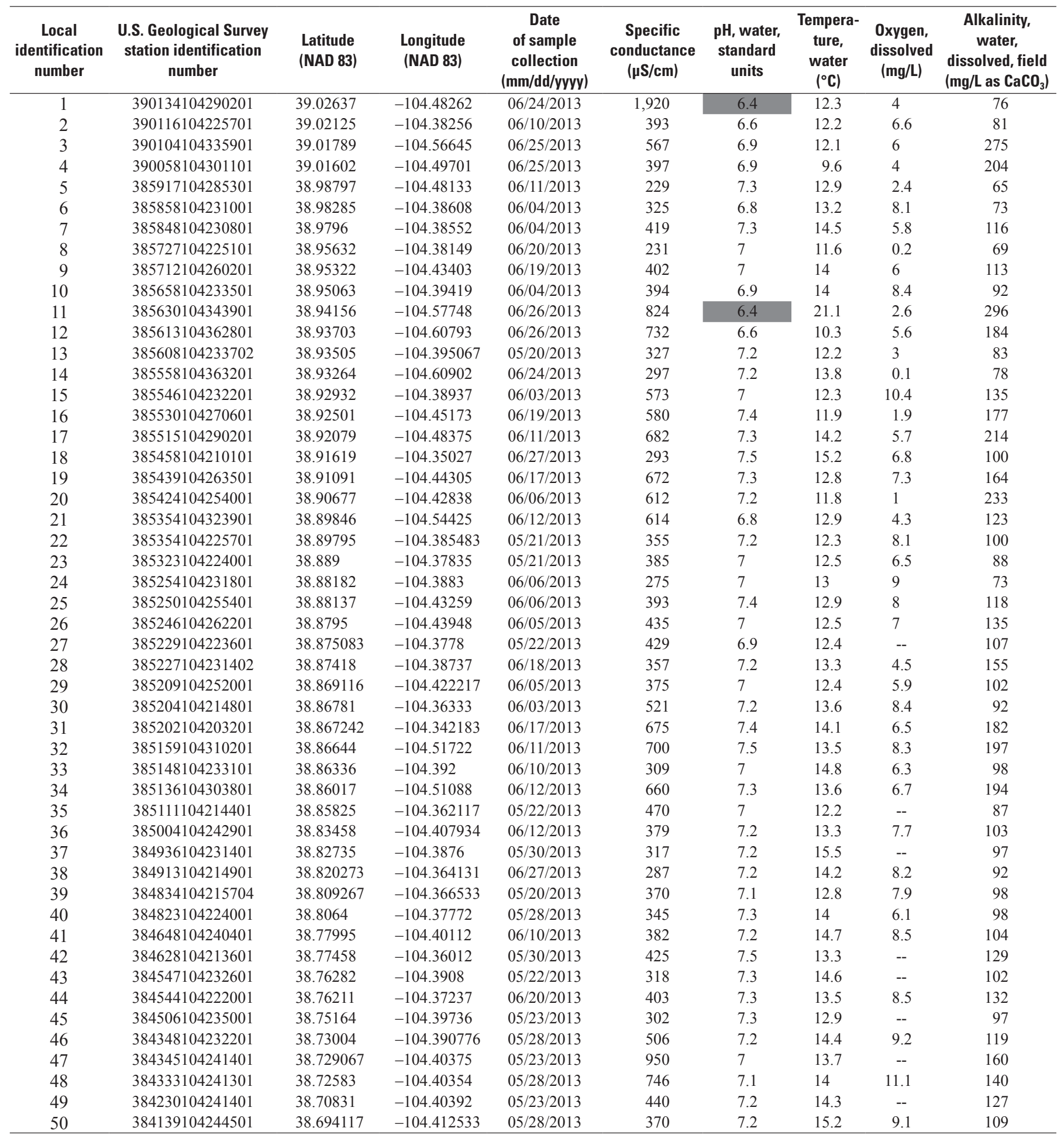

U.S. Environmental Protection Agency Primary Maximum Contaminant Level (MCL) U.S. Environmental Protection Agency Secondary Maximum Contaminant Level (SMCL) 
Table 2. Selected major-ion, nutrient, and fuel products data from groundwater, Upper Black Squirrel primary aquifer, El Paso County, Colorado, 2013.-Continued

[mm, month; dd, day; yyyy, year; E, existing well; M, monitoring well; --, no data; <, less than; ft, feet; >, greater than; $\mu \mathrm{S} / \mathrm{cm}$, microsiemens per centimeter; ${ }^{\circ} \mathrm{C}$, degrees Celsius; $\mathrm{mg} / \mathrm{L}$, milligrams per liter; $\mu \mathrm{g} / \mathrm{L}$, micrograms per liter; $\mathrm{pCi} / \mathrm{L}$, picocuries per liter; $\mathrm{CaCO}_{3}$, calcium carbonate; $\mathrm{N}$, nitrogen; $\mathrm{P}$, phosphorous; R, radchem non-detect, below Sample Specific Critical Level (ssLc); m-, meta; o-, ortha; p-, pera; NAD 83, North American Datum of 1983; shaded areas indicate concentrations that exceed U.S. Environmental Agency National Primary (dark gray) or Secondary Drinking Water Standards (light gray)]

\begin{tabular}{|c|c|c|c|c|c|c|c|c|c|}
\hline $\begin{array}{c}\text { Local } \\
\text { identification } \\
\text { number }\end{array}$ & $\begin{array}{c}\text { U.S. Geological Survey } \\
\text { station identification } \\
\text { number }\end{array}$ & $\begin{array}{l}\text { Calcium, } \\
\text { dissolved } \\
\text { (mg/L) }\end{array}$ & $\begin{array}{c}\text { Magnesium, } \\
\text { dissolved } \\
(\mathrm{mg} / \mathrm{L})\end{array}$ & $\begin{array}{c}\text { Sodium, } \\
\text { dissolved } \\
\text { (mg/L) }\end{array}$ & $\begin{array}{c}\text { Potassium, } \\
\text { dissolved } \\
(\mathrm{mg} / \mathrm{L})\end{array}$ & $\begin{array}{c}\text { Sulfate, } \\
\text { dissolved } \\
\text { (mg/L) }\end{array}$ & $\begin{array}{l}\text { Chloride, } \\
\text { dissolved } \\
(\mathrm{mg} / \mathrm{L})\end{array}$ & $\begin{array}{c}\text { Fluoride, } \\
\text { dissolved } \\
(\mathrm{mg} / \mathrm{L})\end{array}$ & $\begin{array}{c}\text { Silica, } \\
\text { dissolved } \\
\text { (mg/L) }\end{array}$ \\
\hline 1 & 390134104290201 & 135 & 20.5 & 171 & 12.4 & 49.9 & 514 & 0.1 & 19.8 \\
\hline 2 & 390116104225701 & 41.5 & 4.64 & 32.4 & 2.68 & 52.7 & 16 & 0.31 & 31.6 \\
\hline 4 & 390058104301101 & 24.1 & 2.03 & 58.7 & 3.7 & 1.8 & 7.39 & 1.3 & 56 \\
\hline 5 & 385917104285301 & 6.52 & 0.528 & 44.6 & 1.05 & 26.7 & 5.35 & 1.6 & 18.2 \\
\hline 6 & 385858104231001 & 29.7 & 3.77 & 30.5 & 2.11 & 40.1 & 11.6 & 0.26 & 31.1 \\
\hline 9 & 385712104260201 & 27.8 & 2.84 & 49.5 & 4.85 & 48.1 & 20 & 0.46 & 29 \\
\hline 10 & 385658104233501 & 38.7 & 4.55 & 46.3 & 2.9 & 77.7 & 13.7 & 0.3 & 27.2 \\
\hline 11 & 385630104343901 & 84.5 & 7.34 & 75.3 & 6 & 72.2 & 34.2 & 0.14 & 36.1 \\
\hline 12 & 385613104362801 & 101 & 6.33 & 40.3 & 4.35 & 96.7 & 67.8 & 0.31 & 45.5 \\
\hline 13 & 385608104233702 & 18.9 & 2.54 & 43.2 & 1.35 & 40.9 & 8.71 & 0.4 & 24.7 \\
\hline 14 & 385558104363201 & 18.7 & 0.931 & 38.6 & 1.31 & 54.4 & 10.1 & 0.14 & 26.1 \\
\hline 20 & 385424104254001 & 49.8 & 5.64 & 79.1 & 0.93 & 74.2 & 22.7 & 0.61 & 24.9 \\
\hline 21 & 385354104323901 & 57.3 & 6.27 & 56.5 & 4.32 & 77.8 & 61.6 & 0.31 & 31 \\
\hline 22 & 385354104225701 & 23.1 & 3.54 & 48.4 & 2.05 & 36.8 & 9.02 & 0.49 & 29.2 \\
\hline 23 & 385323104224001 & 31.7 & 4.11 & 36.4 & 1.99 & 49.4 & 11.3 & 0.29 & 31.7 \\
\hline 24 & 385254104231801 & 20.7 & 2.32 & 30.6 & 1.48 & 33.4 & 4.92 & 0.43 & 30.7 \\
\hline 25 & 385250104255401 & 33.7 & 3.3 & 46.4 & 1.9 & 42.8 & 7.14 & 0.42 & 27.3 \\
\hline 26 & 385246104262201 & 35.8 & 3.53 & 50 & 2.47 & 58.9 & 10.1 & 0.43 & 30.1 \\
\hline 27 & 385229104223601 & 39.5 & 4.79 & 42.9 & 2.23 & 49.6 & 13.2 & 0.37 & 30.5 \\
\hline 28 & 385227104231402 & 15 & 1.46 & 62.4 & 1.01 & 21.1 & 3.99 & 0.63 & 22.4 \\
\hline 29 & 385209104252001 & 36 & 3.66 & 38.1 & 2.69 & 46.1 & 11.1 & 0.38 & 30.8 \\
\hline 30 & 385204104214801 & 45.5 & 5.36 & 55.9 & 2.38 & 95.2 & 27 & 0.42 & 27.5 \\
\hline 31 & 385202104203201 & 38.7 & 4.24 & 98.2 & 1.07 & 95.7 & 41.2 & 0.54 & 17.8 \\
\hline 32 & 385159104310201 & 48.5 & 3.88 & 104 & 1.67 & 129 & 23.1 & 0.6 & 20.1 \\
\hline 41 & 384648104240401 & 31.7 & 3.27 & 46.8 & 1.98 & 53 & 11.9 & 0.51 & 28 \\
\hline 42 & 384628104213601 & 25 & 2.49 & 62 & 1.49 & 43.2 & 6.59 & 1.51 & 21.3 \\
\hline 43 & 384547104232601 & 30.6 & 3.03 & 33.8 & 2.35 & 33.6 & 7.05 & 0.59 & 31.1 \\
\hline 44 & 384544104222001 & 30.7 & 3.03 & 49.6 & 1.58 & 42.6 & 7.1 & 0.55 & 25.2 \\
\hline 45 & 384506104235001 & 28.5 & 2.9 & 33.6 & 2.37 & 31.1 & 6.72 & 0.6 & 29.8 \\
\hline 46 & 384348104232201 & 44.8 & 4.97 & 56.1 & 2.31 & 82 & 18.5 & 0.58 & 26.4 \\
\hline 47 & 384345104241401 & 100 & 10.9 & 78.4 & 4.15 & 119 & 101 & 0.41 & 29.8 \\
\hline 48 & 384333104241301 & 77 & 8.64 & 65.4 & 3.54 & 104 & 69.4 & 0.42 & 29.8 \\
\hline 49 & 384230104241401 & 43.7 & 4.58 & 45 & 2.61 & 67.3 & 12.5 & 0.49 & 29.6 \\
\hline 50 & 384139104244501 & 33.1 & 3.91 & 39.3 & 2.37 & 51.6 & 8.93 & 0.52 & 29.4 \\
\hline \multirow{2}{*}{\multicolumn{2}{|c|}{$\begin{array}{l}\text { U.S. Environmental Protection Agency Primary } \\
\text { Maximum Contaminant Level (MCL) } \\
\text { U.S. Environmental Protection Agency Secondary } \\
\text { Maximum Contaminant Level (SMCL) }\end{array}$}} & -- & -- & -- & -- & -- & -- & 4 & -- \\
\hline & & -- & -- & -- & -- & 250 & 250 & 2 & -- \\
\hline
\end{tabular}


Table 2. Selected major-ion, nutrient, and fuel products data from groundwater, Upper Black Squirrel primary aquifer, El Paso County, Colorado, 2013.-Continued

[mm, month; dd, day; yyyy, year; E, existing well; M, monitoring well; --, no data; <, less than; ft, feet; >, greater than; $\mu \mathrm{S} / \mathrm{cm}$, microsiemens per centimeter; ${ }^{\circ} \mathrm{C}$, degrees Celsius; $\mathrm{mg} / \mathrm{L}$, milligrams per liter; $\mu \mathrm{g} / \mathrm{L}$, micrograms per liter; $\mathrm{pCi} / \mathrm{L}$, picocuries per liter; $\mathrm{CaCO}_{3}$, calcium carbonate; $\mathrm{N}$, nitrogen; $\mathrm{P}$, phosphorous; R, radchem non-detect, below Sample Specific Critical Level (ssLc); m-, meta; o-, ortha; p-, pera; NAD 83, North American Datum of 1983; shaded areas indicate concentrations that exceed U.S. Environmental Agency National Primary (dark gray) or Secondary Drinking Water Standards (light gray)]

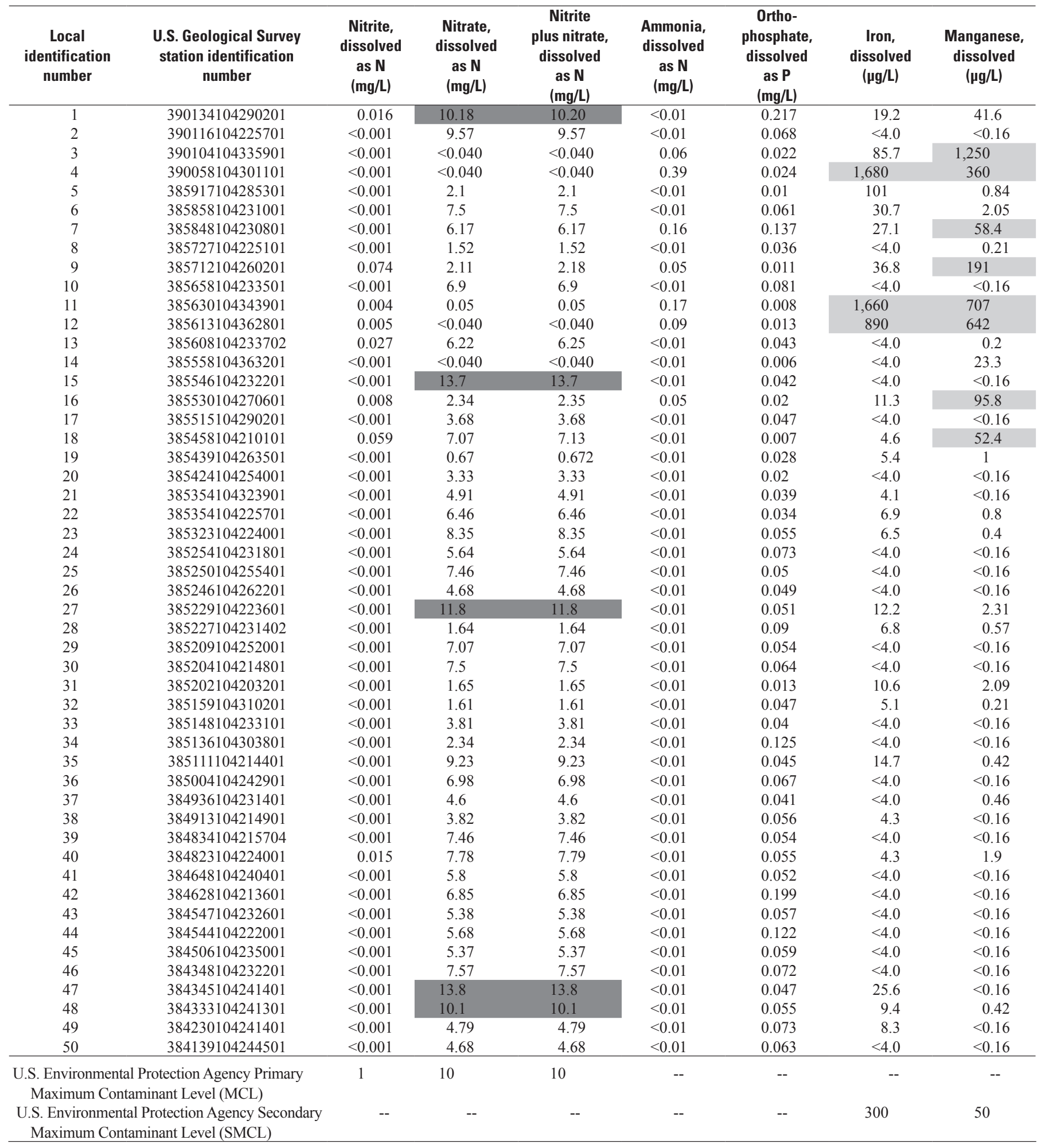


Table 2. Selected major-ion, nutrient, and fuel products data from groundwater, Upper Black Squirrel primary aquifer, El Paso County, Colorado, 2013.-Continued

[mm, month; dd, day; yyyy, year; E, existing well; M, monitoring well; --, no data; <, less than; ft, feet; >, greater than; $\mu \mathrm{S} / \mathrm{cm}$, microsiemens per centimeter; ${ }^{\circ} \mathrm{C}$, degrees Celsius; $\mathrm{mg} / \mathrm{L}$, milligrams per liter; $\mu \mathrm{g} / \mathrm{L}$, micrograms per liter; $\mathrm{pCi} / \mathrm{L}$, picocuries per liter; $\mathrm{CaCO}_{3}$, calcium carbonate; $\mathrm{N}$, nitrogen; $\mathrm{P}$, phosphorous; R, radchem non-detect, below Sample Specific Critical Level (ssLc); m-, meta; o-, ortha; p-, pera; NAD 83, North American Datum of 1983; shaded areas indicate concentrations that exceed U.S. Environmental Agency National Primary (dark gray) or Secondary Drinking Water Standards (light gray)]

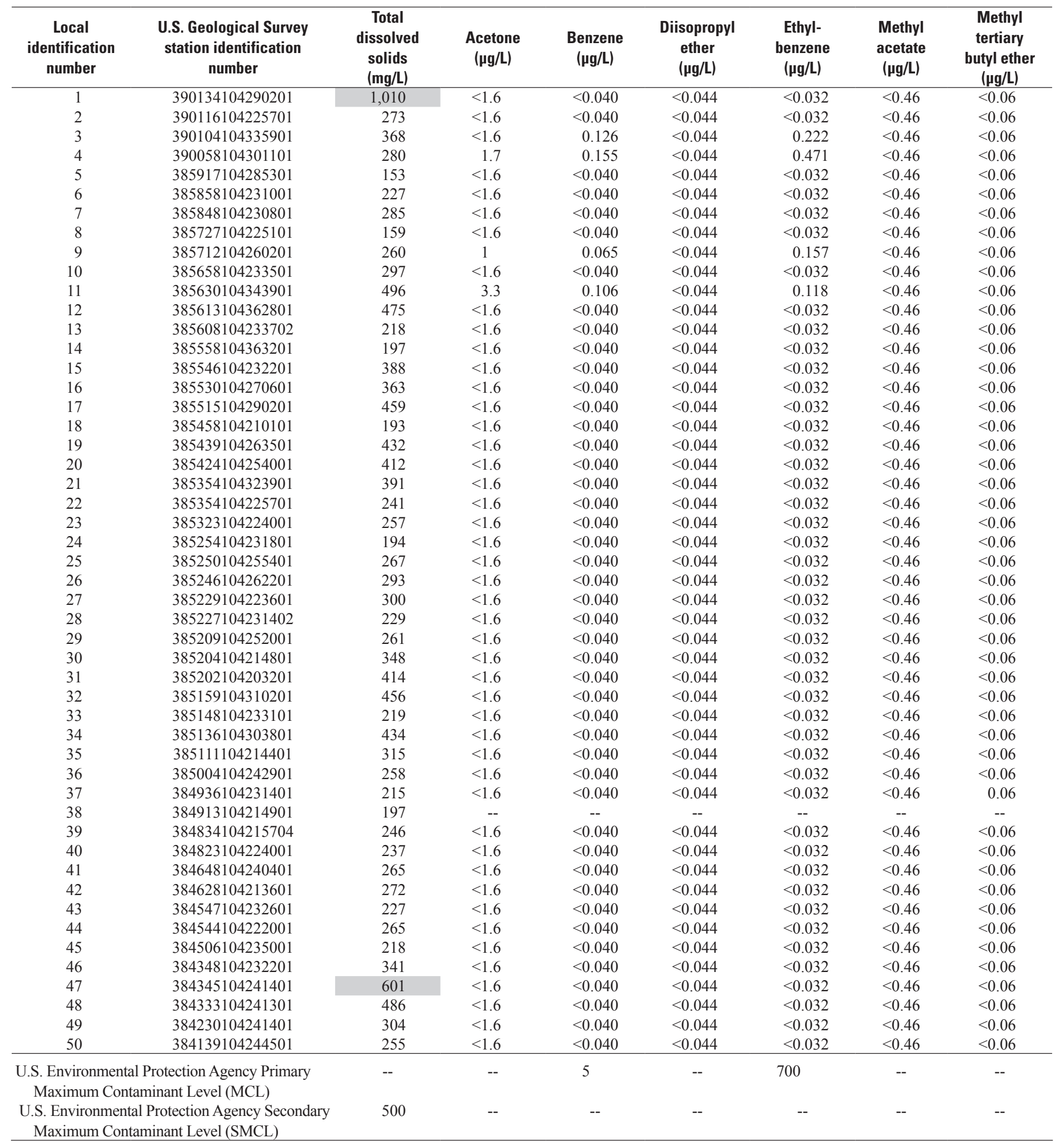


Table 2. Selected major-ion, nutrient, and fuel products data from groundwater, Upper Black Squirrel primary aquifer, El Paso County, Colorado, 2013.-Continued

[mm, month; dd, day; yyyy, year; E, existing well; M, monitoring well; --, no data; <, less than; ft, feet; >, greater than; $\mu \mathrm{S} / \mathrm{cm}$, microsiemens per centimeter; ${ }^{\circ} \mathrm{C}$, degrees Celsius; $\mathrm{mg} / \mathrm{L}$, milligrams per liter; $\mu \mathrm{g} / \mathrm{L}$, micrograms per liter; $\mathrm{pCi} / \mathrm{L}$, picocuries per liter; $\mathrm{CaCO}_{3}$, calcium carbonate; $\mathrm{N}$, nitrogen; $\mathrm{P}$, phosphorous; R, radchem non-detect, below Sample Specific Critical Level (ssLc); m-, meta; o-, ortha; p-, pera; NAD 83, North American Datum of 1983; shaded areas indicate concentrations that exceed U.S. Environmental Agency National Primary (dark gray) or Secondary Drinking Water Standards (light gray)]

\begin{tabular}{|c|c|c|c|c|c|c|c|c|}
\hline $\begin{array}{c}\text { Local } \\
\text { identification } \\
\text { number }\end{array}$ & $\begin{array}{c}\text { U.S. Geological Survey } \\
\text { station identification } \\
\text { number }\end{array}$ & $\begin{array}{c}\text { Methyl } \\
\text { tert-pentyl } \\
\text { ether } \\
(\mu \mathrm{g} / \mathrm{L})\end{array}$ & $\begin{array}{c}\mathrm{m}-+p- \\
\text { Xylene } \\
(\mu \mathrm{g} / \mathrm{L})\end{array}$ & $\begin{array}{l}\text { o-Xylene } \\
(\mu \mathrm{g} / \mathrm{L})\end{array}$ & $\begin{array}{c}\text { tert-Amyl } \\
\text { alcohol } \\
(\mu \mathrm{g} / \mathrm{L})\end{array}$ & $\begin{array}{c}\text { tert-Butyl } \\
\text { alcohol } \\
\text { ( } \mu \mathrm{g} / \mathrm{L})\end{array}$ & $\begin{array}{l}\text { tert-Butyl } \\
\text { ethyl ether } \\
(\mu \mathrm{g} / \mathrm{L})\end{array}$ & $\begin{array}{l}\text { Toluene } \\
(\mu \mathrm{g} / \mathrm{L})\end{array}$ \\
\hline 2 & 390116104225701 & $<0.044$ & $<0.05$ & $<0.028$ & $<0.6$ & $<0.80$ & $<0.06$ & $<0.02$ \\
\hline 3 & 390104104335901 & $<0.044$ & 0.79 & 0.405 & $<0.6$ & $<0.80$ & $<0.06$ & 0.18 \\
\hline 4 & 390058104301101 & $<0.044$ & 2.8 & 0.956 & $<0.6$ & $<0.80$ & $<0.06$ & 1.57 \\
\hline 5 & 385917104285301 & $<0.044$ & $<0.05$ & $<0.028$ & $<0.6$ & $<0.80$ & $<0.06$ & $<0.02$ \\
\hline 8 & 385727104225101 & $<0.044$ & $<0.05$ & $<0.028$ & $<0.6$ & $<0.80$ & $<0.06$ & $<0.02$ \\
\hline 9 & 385712104260201 & $<0.044$ & 0.59 & 0.266 & $<0.6$ & $<0.80$ & $<0.06$ & 0.5 \\
\hline 10 & 385658104233501 & $<0.044$ & $<0.05$ & $<0.028$ & $<0.6$ & $<0.80$ & $<0.06$ & $<0.02$ \\
\hline 11 & 385630104343901 & $<0.044$ & 0.59 & 0.208 & $<0.6$ & $<0.80$ & $<0.06$ & 0.44 \\
\hline 12 & 385613104362801 & $<0.044$ & $<0.05$ & $<0.028$ & $<0.6$ & $<0.80$ & $<0.06$ & $<0.02$ \\
\hline 13 & 385608104233702 & $<0.044$ & $<0.05$ & $<0.028$ & $<0.6$ & $<0.80$ & $<0.06$ & $<0.02$ \\
\hline 19 & 385439104263501 & $<0.044$ & $<0.05$ & $<0.028$ & $<0.6$ & $<0.80$ & $<0.06$ & $<0.02$ \\
\hline 20 & 385424104254001 & $<0.044$ & $<0.05$ & $<0.028$ & $<0.6$ & $<0.80$ & $<0.06$ & $<0.02$ \\
\hline 21 & 385354104323901 & $<0.044$ & $<0.05$ & $<0.028$ & $<0.6$ & $<0.80$ & $<0.06$ & $<0.02$ \\
\hline 22 & 385354104225701 & $<0.044$ & $<0.05$ & $<0.028$ & $<0.6$ & $<0.80$ & $<0.06$ & $<0.02$ \\
\hline 23 & 385323104224001 & $<0.044$ & $<0.05$ & $<0.028$ & $<0.6$ & $<0.80$ & $<0.06$ & $<0.02$ \\
\hline 24 & 385254104231801 & $<0.044$ & $<0.05$ & $<0.028$ & $<0.6$ & $<0.80$ & $<0.06$ & $<0.02$ \\
\hline 25 & 385250104255401 & $<0.044$ & $<0.05$ & $<0.028$ & $<0.6$ & $<0.80$ & $<0.06$ & $<0.02$ \\
\hline 26 & 385246104262201 & $<0.044$ & $<0.05$ & $<0.028$ & $<0.6$ & $<0.80$ & $<0.06$ & $<0.02$ \\
\hline 27 & 385229104223601 & $<0.044$ & $<0.05$ & $<0.028$ & $<0.6$ & $<0.80$ & $<0.06$ & $<0.02$ \\
\hline 28 & 385227104231402 & $<0.044$ & $<0.05$ & $<0.028$ & $<0.6$ & $<0.80$ & $<0.06$ & $<0.02$ \\
\hline 29 & 385209104252001 & $<0.044$ & $<0.05$ & $<0.028$ & $<0.6$ & $<0.80$ & $<0.06$ & $<0.02$ \\
\hline 30 & 385204104214801 & $<0.044$ & $<0.05$ & $<0.028$ & $<0.6$ & $<0.80$ & $<0.06$ & $<0.02$ \\
\hline 31 & 385202104203201 & $<0.044$ & $<0.05$ & $<0.028$ & $<0.6$ & $<0.80$ & $<0.06$ & $<0.02$ \\
\hline 40 & 384823104224001 & $<0.044$ & $<0.05$ & $<0.028$ & $<0.6$ & $<0.80$ & $<0.06$ & $<0.02$ \\
\hline 41 & 384648104240401 & $<0.044$ & $<0.05$ & $<0.028$ & $<0.6$ & $<0.80$ & $<0.06$ & $<0.02$ \\
\hline 42 & 384628104213601 & $<0.044$ & $<0.05$ & $<0.028$ & $<0.6$ & $<0.80$ & $<0.06$ & $<0.02$ \\
\hline 43 & 384547104232601 & $<0.044$ & $<0.05$ & $<0.028$ & $<0.6$ & $<0.80$ & $<0.06$ & $<0.02$ \\
\hline 44 & 384544104222001 & $<0.044$ & $<0.05$ & $<0.028$ & $<0.6$ & $<0.80$ & $<0.06$ & $<0.02$ \\
\hline 45 & 384506104235001 & $<0.044$ & $<0.05$ & $<0.028$ & $<0.6$ & $<0.80$ & $<0.06$ & $<0.02$ \\
\hline 46 & 384348104232201 & $<0.044$ & $<0.05$ & $<0.028$ & $<0.6$ & $<0.80$ & $<0.06$ & $<0.02$ \\
\hline 47 & 384345104241401 & $<0.044$ & $<0.05$ & $<0.028$ & $<0.6$ & $<0.80$ & $<0.06$ & $<0.02$ \\
\hline 48 & 384333104241301 & $<0.044$ & $<0.05$ & $<0.028$ & $<0.6$ & $<0.80$ & $<0.06$ & $<0.02$ \\
\hline 49 & 384230104241401 & $<0.044$ & $<0.05$ & $<0.028$ & $<0.6$ & $<0.80$ & $<0.06$ & 0.06 \\
\hline 50 & 384139104244501 & $<0.044$ & $<0.05$ & $<0.028$ & $<0.6$ & $<0.80$ & $<0.06$ & $<0.02$ \\
\hline \multicolumn{2}{|c|}{$\begin{array}{l}\text { U.S. Environmental Protection Agency Primary } \\
\text { Maximum Contaminant Level (MCL) }\end{array}$} & -- & 10,000 & 10,000 & -- & -- & -- & 1,000 \\
\hline \multicolumn{2}{|c|}{$\begin{array}{l}\text { U.S. Environmental Protection Agency Secondary } \\
\text { Maximum Contaminant Level (SMCL) }\end{array}$} & -- & -- & -- & -- & -- & -- & -- \\
\hline
\end{tabular}


Table 3. Dissolved gas data analyzed from groundwater samples collected from the Upper Black Squirrel primary aquifer, El Paso County, Colorado, 2013.

[mm, month; dd, day; yyyy, year; ${ }^{\circ} \mathrm{C}$, degrees Celsius; NGVD 83, National Geodetic Vertical Datum of 1983; mg/L, milligrams per liter; <, less than; cm ${ }^{3} \mathrm{~L}$, cubic centimeters per liter; STP, standard temperature and pressure]

\begin{tabular}{|c|c|c|c|c|c|c|c|c|c|c|c|c|}
\hline $\begin{array}{c}\text { Local } \\
\text { identification } \\
\text { number }\end{array}$ & $\begin{array}{c}\text { U.S. Geological Survey } \\
\text { station identification } \\
\text { number }\end{array}$ & $\begin{array}{l}\text { Date of sample } \\
\text { collection } \\
\text { (mm/dd/yyyy) }\end{array}$ & $\begin{array}{l}\text { Water temperature } \\
\text { at time of collection } \\
\left({ }^{\circ} \mathrm{C}\right)\end{array}$ & $\begin{array}{c}\text { Nitrogen } \\
\left(\mathbf{N}_{2}\right) \\
(\mathbf{m g} / \mathrm{L})\end{array}$ & $\begin{array}{l}\text { Argon } \\
\text { (Ar) } \\
\text { (mg/L) }\end{array}$ & $\begin{array}{l}\text { Oxygen } \\
\left(\mathrm{O}_{2}\right) \\
(\mathrm{mg} / \mathrm{L})\end{array}$ & $\begin{array}{c}\text { Carbon } \\
\text { dioxide } \\
\left(\mathrm{CO}_{2}\right) \\
(\mathrm{mg} / \mathrm{L}) \\
\end{array}$ & $\begin{array}{c}\text { Methane } \\
\qquad\left(\mathrm{CH}_{4}\right) \\
(\mathrm{mg} / \mathrm{L})\end{array}$ & $\begin{array}{c}\text { Estimated } \\
\text { recharge altitude } \\
\text { (meters above } \\
\text { NGVD 83) }\end{array}$ & $\begin{array}{c}\text { Calculated recharge } \\
\text { temperature } \\
\left({ }^{\circ} \mathrm{C}\right)\end{array}$ & $\begin{array}{l}\text { Excess air in } \\
\text { water sample } \\
\left(\mathrm{cm}^{3} / \mathrm{L} \text { at STP }\right)\end{array}$ & $\begin{array}{c}\text { Excess } \\
\text { nitrogen } \\
\left(\mathrm{N}_{2}\right) \\
(\mathrm{mg} / \mathrm{L})\end{array}$ \\
\hline 1 & 390134104290201 & $06 / 24 / 2013$ & 12.3 & 14.97 & 0.56 & 2.12 & 46.84 & $<0.0001$ & 2,072 & 9.2 & 0.7 & 0 \\
\hline 2 & 390116104225701 & $06 / 10 / 2013$ & 12.2 & 15.81 & 0.55 & 5.46 & 26.12 & $<0.0001$ & 2,021 & 12.7 & 2.5 & 0 \\
\hline 4 & 390058104301101 & $06 / 25 / 2013$ & 9.6 & 16.73 & 0.58 & 0.21 & 39.01 & 0.2727 & 2,080 & 10.3 & 2.8 & 0 \\
\hline 5 & 385917104285301 & $06 / 11 / 2013$ & 12.9 & 18.59 & 0.59 & 1.75 & 5.47 & 0.0004 & 2,037 & 12.9 & 5.4 & 0 \\
\hline 6 & 385858104231001 & $06 / 04 / 2013$ & 13.2 & 16.47 & 0.57 & 5.84 & 18.54 & $<0.0001$ & 1,966 & 11.7 & 2.8 & 0 \\
\hline 7 & 385848104230801 & $06 / 04 / 2013$ & 14.5 & 17.23 & 0.59 & 5.02 & 12.08 & 0.0087 & 1,958 & 9.7 & 2.9 & 0 \\
\hline 8 & 385727104225101 & $06 / 20 / 2013$ & 11.6 & 21.87 & 0.62 & 0.29 & 8.28 & $<0.0001$ & 1,935 & 8.2 & 3.0 & 4 \\
\hline 9 & 385712104260201 & $06 / 19 / 2013$ & 14.0 & 15.75 & 0.56 & 3.62 & 23.15 & 0.0019 & 1,974 & 11.0 & 1.9 & 0 \\
\hline 10 & 385658104233501 & $06 / 04 / 2013$ & 14.0 & 18.05 & 0.62 & 6.55 & 18.59 & $<0.0001$ & 1,931 & 8.4 & 3.3 & 0 \\
\hline 11 & 385630104343901 & $06 / 26 / 2013$ & 21.1 & 19.20 & 0.58 & 0.45 & 170.27 & 0.0523 & 2,084 & 11.2 & 3.6 & 2 \\
\hline 12 & 385613104362801 & $06 / 26 / 2013$ & 10.3 & 16.85 & 0.58 & 1.02 & 70.60 & 0.0870 & 2,089 & 10.4 & 3.0 & 0 \\
\hline 13 & 385608104233702 & 05/20/2013 & 12.2 & 19.93 & 0.60 & 3.06 & 7.35 & 0.0010 & 1,928 & 15.8 & 7.4 & 0 \\
\hline 14 & 385558104363201 & $06 / 24 / 2013$ & 13.8 & 19.53 & 0.64 & 0.31 & 7.65 & 0.0153 & 2,082 & 6.5 & 3.4 & 1 \\
\hline 15 & 385546104232201 & $06 / 03 / 2013$ & 12.3 & 17.92 & 0.62 & 9.09 & 20.15 & $<0.0001$ & 1,920 & 7.5 & 2.8 & 0 \\
\hline 16 & 385530104270601 & $06 / 19 / 2013$ & 11.9 & 15.52 & 0.55 & 0.78 & 15.88 & $<0.0001$ & 1,952 & 11.4 & 1.7 & 0 \\
\hline 17 & 385515104290201 & $06 / 11 / 2013$ & 14.2 & 15.17 & 0.55 & 4.48 & 17.86 & $<0.0001$ & 1,974 & 10.9 & 1.2 & 0 \\
\hline 18 & 385458104210101 & $06 / 27 / 2013$ & 15.2 & 14.68 & 0.54 & 6.51 & 5.22 & $<0.0001$ & 1,907 & 11.6 & 0.8 & 0 \\
\hline 19 & 385439104263501 & $06 / 17 / 2013$ & 12.8 & 15.00 & 0.55 & 7.10 & 13.44 & $<0.0001$ & 1,934 & 10.4 & 0.8 & 0 \\
\hline 20 & 385424104254001 & $06 / 06 / 2013$ & 11.8 & 16.69 & 0.57 & 0.82 & 20.52 & $<0.0001$ & 1,923 & 11.9 & 3.0 & 0 \\
\hline 21 & 385354104323901 & $06 / 12 / 2013$ & 12.9 & 17.33 & 0.59 & 3.81 & 32.34 & $<0.0001$ & 1,995 & 9.7 & 3.1 & 0 \\
\hline 22 & 385354104225701 & $05 / 21 / 2013$ & 12.3 & 15.71 & 0.57 & 7.75 & 11.75 & $<0.0001$ & 1,888 & 10.1 & 1.4 & 0 \\
\hline 23 & 385323104224001 & $05 / 21 / 2013$ & 12.5 & 18.20 & 0.61 & 6.92 & 16.27 & $<0.0001$ & 1,876 & 10.5 & 4.0 & 0 \\
\hline 24 & 385254104231801 & $06 / 06 / 2013$ & 13.0 & 14.81 & 0.54 & 7.16 & 11.01 & $<0.0001$ & 1,876 & 12.1 & 1.1 & 0 \\
\hline 25 & 385250104255401 & $06 / 06 / 2013$ & 12.9 & 19.24 & 0.63 & 6.03 & 11.29 & $<0.0001$ & 1,899 & 10.1 & 5.0 & 0 \\
\hline 26 & 385246104262201 & $06 / 05 / 2013$ & 12.5 & 18.75 & 0.61 & 6.88 & 17.52 & $<0.0001$ & 1,904 & 11.8 & 5.1 & 0 \\
\hline 27 & 385229104223601 & $05 / 22 / 2013$ & 12.4 & 19.73 & 0.66 & 9.46 & 18.77 & $<0.0001$ & 1,864 & 6.9 & 4.3 & 0 \\
\hline 28 & 385227104231402 & $06 / 18 / 2013$ & 13.3 & 18.10 & 0.60 & 2.77 & 14.91 & $<0.0001$ & 1,866 & 11.6 & 4.3 & 0 \\
\hline 29 & 385209104252001 & $06 / 05 / 2013$ & 12.4 & 17.57 & 0.59 & 6.65 & 17.07 & $<0.0001$ & 1,868 & 6.0 & 3.9 & 0 \\
\hline 30 & 385204104214801 & $06 / 03 / 2013$ & 13.6 & 14.38 & 0.53 & 7.23 & 10.99 & $<0.0001$ & 1,881 & 11.9 & 0.6 & 0 \\
\hline 31 & 385202104203201 & $06 / 17 / 2013$ & 14.1 & 15.40 & 0.54 & 4.48 & 10.83 & $<0.0001$ & 1,849 & 13.5 & 2.0 & 0 \\
\hline 32 & 385159104310201 & $06 / 11 / 2013$ & 13.5 & 17.68 & 0.59 & 6.75 & 10.26 & $<0.0001$ & 1,848 & 11.3 & 3.7 & 0 \\
\hline 33 & 385148104233101 & $06 / 10 / 2013$ & 14.8 & 18.79 & 0.65 & 5.67 & 16.77 & $<0.0001$ & 1,854 & 6.9 & 3.4 & 0 \\
\hline 34 & 385136104303801 & $06 / 12 / 2013$ & 13.6 & 15.78 & 0.57 & 5.56 & 13.80 & $<0.0001$ & 1,935 & 10.3 & 1.6 & 0 \\
\hline 35 & 385111104214401 & $05 / 22 / 2013$ & 12.2 & 16.03 & 0.56 & 5.60 & 14.51 & $<0.0001$ & 1,836 & 11.6 & 2.1 & 0 \\
\hline 36 & 385004104242901 & $06 / 12 / 2013$ & 13.3 & 16.78 & 0.59 & 6.53 & 11.20 & $<0.0001$ & 1,841 & 10.2 & 2.4 & 0 \\
\hline 37 & 384936104231401 & $05 / 30 / 2013$ & 15.5 & 21.40 & 0.68 & 5.21 & 10.76 & $<0.0001$ & 1,823 & 8.9 & 6.7 & 0 \\
\hline 39 & 384834104215704 & $05 / 20 / 2013$ & 12.8 & 16.04 & 0.57 & 6.72 & 12.23 & $<0.0001$ & 1,802 & 10.8 & 1.8 & 0 \\
\hline 40 & 384823104224001 & $05 / 28 / 2013$ & 14.0 & 18.04 & 0.61 & 5.82 & 8.50 & $<0.0001$ & 1,798 & 9.6 & 3.4 & 0 \\
\hline 41 & 384648104240401 & $06 / 10 / 2013$ & 14.7 & 14.97 & 0.55 & 7.92 & 8.06 & $<0.0001$ & 1,823 & 11.6 & 1.0 & 0 \\
\hline 42 & 384628104213601 & $05 / 30 / 2013$ & 13.3 & 16.05 & 0.57 & 7.79 & 6.88 & $<0.0001$ & 1,790 & 11.7 & 2.1 & 0 \\
\hline 43 & 384547104232601 & $05 / 22 / 2013$ & 14.6 & 17.34 & 0.59 & 6.59 & 7.98 & $<0.0001$ & 1,767 & 11.2 & 3.2 & 0 \\
\hline 44 & 384544104222001 & $06 / 20 / 2013$ & 13.5 & 14.79 & 0.54 & 5.77 & 10.80 & $<0.0001$ & 1,765 & 12.2 & 0.9 & 0 \\
\hline 45 & 384506104235001 & $05 / 23 / 2013$ & 12.9 & 18.00 & 0.61 & 6.98 & 7.93 & $<0.0001$ & 1,766 & 10.6 & 3.7 & 0 \\
\hline 46 & 384348104232201 & $05 / 28 / 2013$ & 14.4 & 16.06 & 0.58 & 7.67 & 10.60 & $<0.0001$ & 1,730 & 10.2 & 1.5 & 0 \\
\hline 47 & 384345104241401 & $05 / 23 / 2013$ & 13.7 & 21.95 & 0.71 & 9.24 & 21.86 & $<0.0001$ & 1,741 & 6.6 & 6.3 & 0 \\
\hline 48 & 384333104241301 & $05 / 28 / 2013$ & 14.0 & 18.70 & 0.65 & 8.56 & 20.04 & $<0.0001$ & 1,739 & 6.4 & 2.9 & 0 \\
\hline 49 & 384230104241401 & $05 / 23 / 2013$ & 14.3 & 16.70 & 0.59 & 7.13 & 15.37 & $<0.0001$ & 1,714 & 10.7 & 2.3 & 0 \\
\hline 50 & 384139104244501 & $05 / 28 / 2013$ & 15.2 & 15.67 & 0.56 & 6.99 & 8.07 & $<0.0001$ & 1,714 & 11.8 & 1.6 & 0 \\
\hline
\end{tabular}


Table 4. Selected groundwater-quality data used to interpret groundwater recharge ages using chlorofluorocarbons and tritium, Upper Black Squirrel primary aquifer, El Paso County, Colorado, 2013.

[CFC, chlorofluorocarbon; ${ }^{\circ} \mathrm{C}$, degrees Celsius; $\mathrm{cm}^{3} / \mathrm{kg}$, cubic centimeters excess air at standard temperature and pressure per kilogram of water; ppt, parts per trillion; $\mu \mathrm{g} / \mathrm{L}$, micrograms per liter; $\mathrm{pCi} / \mathrm{L}$, picocuries per liter; $\mathrm{pg} / \mathrm{kg}$, picograms per kilogram of water; R, radchem non-detect, below Sample-Specific Critical Level (ssLC); NGVD 83, National Geodetic Vertical Datum of 1983; TU, tritium units; --, no value; ${ }^{3} \mathrm{H}$, tritium]

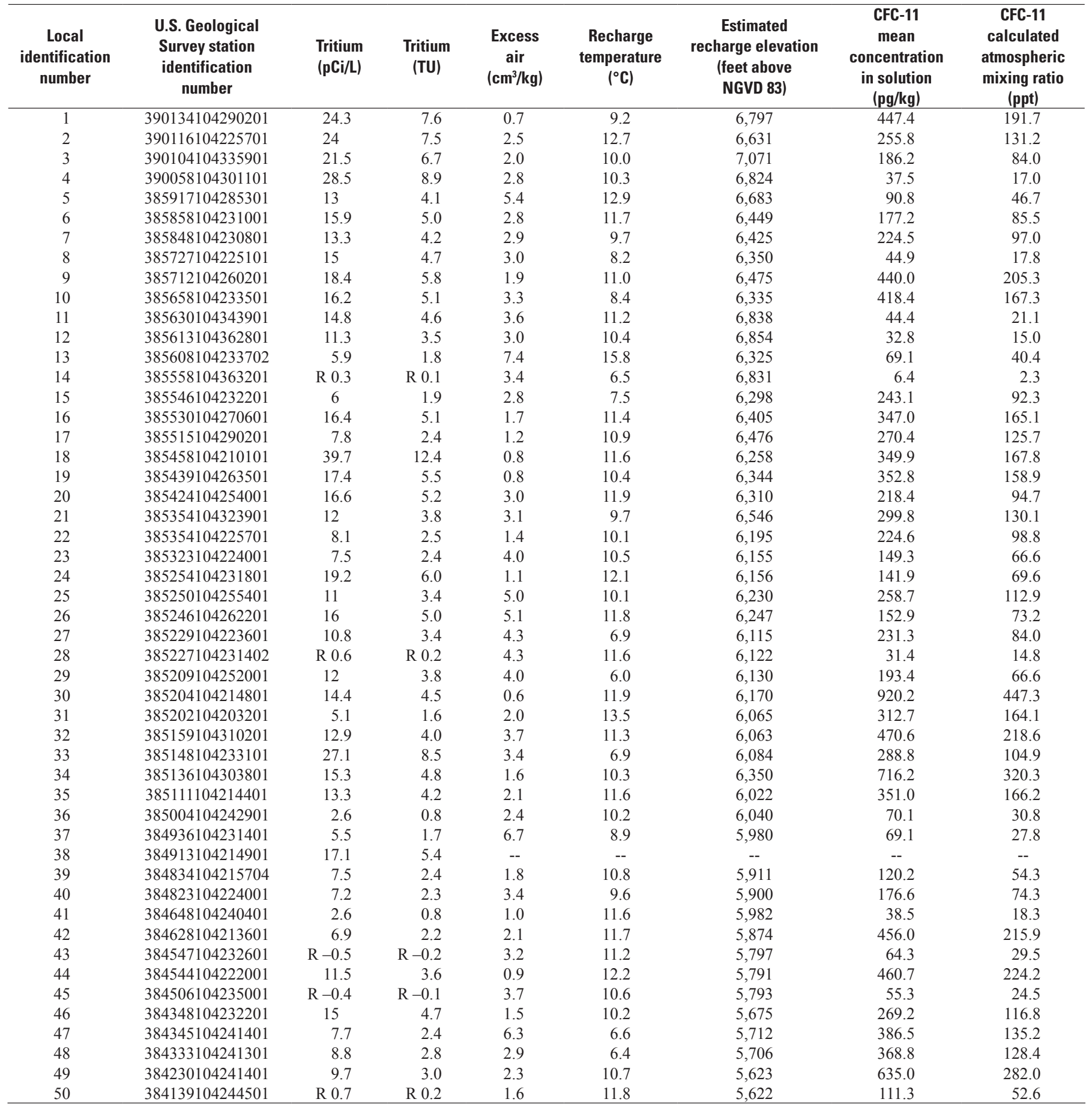


Table 4. Selected groundwater-quality data used to interpret groundwater recharge ages using chlorofluorocarbons and tritium, Upper Black Squirrel primary aquifer, El Paso County, Colorado, 2013._-Continued

[CFC, chlorofluorocarbon; ${ }^{\circ} \mathrm{C}$, degrees Celsius; $\mathrm{cm}^{3} / \mathrm{kg}$, cubic centimeters excess air at standard temperature and pressure per kilogram of water; ppt, parts per trillion; $\mu \mathrm{g} / \mathrm{L}$, micrograms per liter; $\mathrm{pCi} / \mathrm{L}$, picocuries per liter; $\mathrm{pg} / \mathrm{kg}$, picograms per kilogram of water; $\mathrm{R}$, radchem non-detect, below Sample-Specific Critical Level (ssLC); NGVD 83, National Geodetic Vertical Datum of 1983; TU, tritium units; --, no value; ${ }^{3} \mathrm{H}$, tritium]

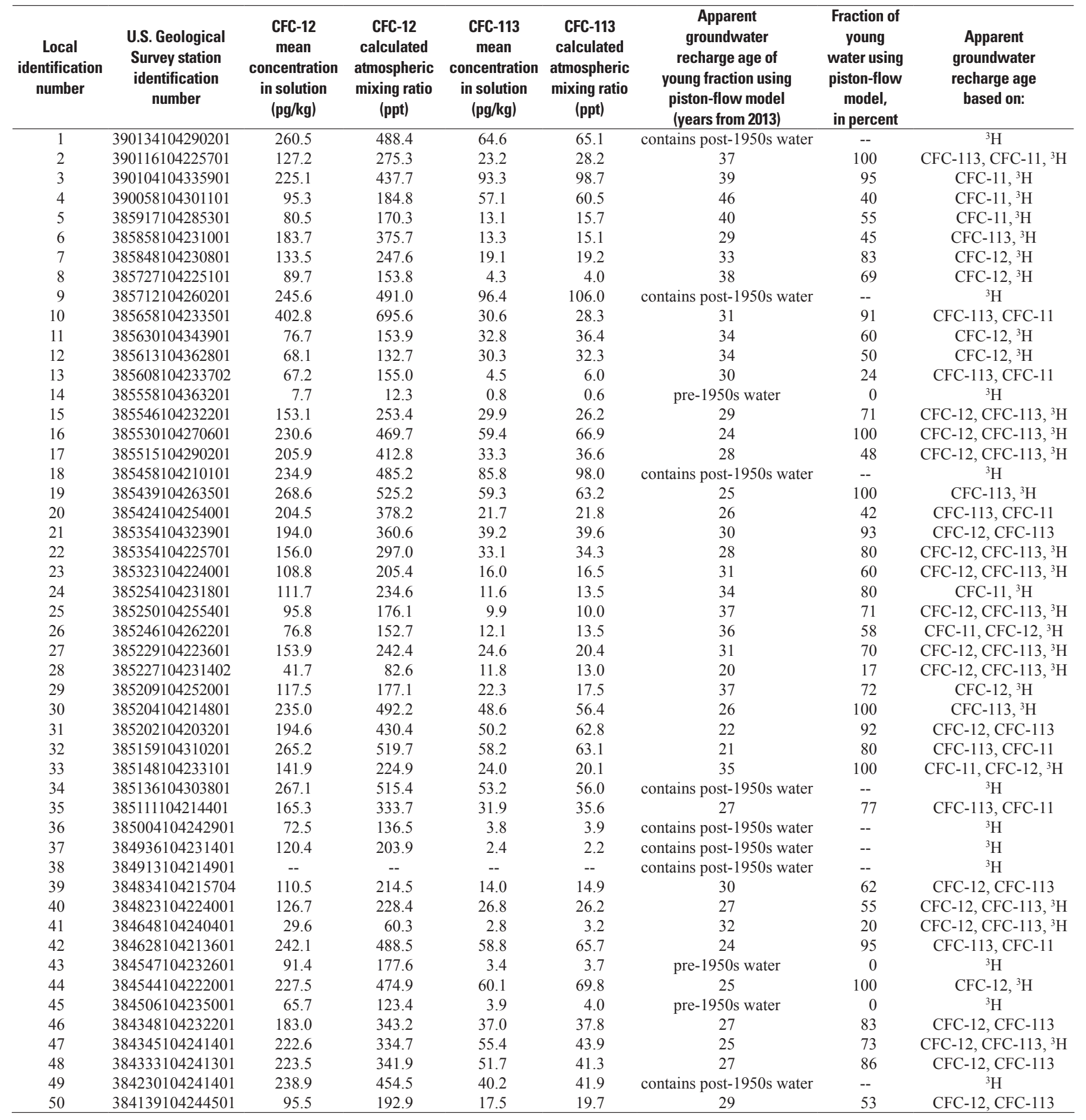


Table 5. Analyses of blank samples of major ions, nutrients, and fuel products in groundwater, Upper Black Squirrel primary aquifer, El Paso County, Colorado, 2013.

[mm, month; dd, day; yyyy, year; <, less than laboratory reporting level; mg/L milligrams per liter; $\mu \mathrm{g} / \mathrm{L}$, micrograms per liter; $\mathrm{CaCO}_{3}$, calcium carbonate; m-, meta; o-, ortha; p-, pera]

\begin{tabular}{|c|c|c|c|c|c|c|c|}
\hline $\begin{array}{l}\text { Local identification number } \\
\text { Sample type } \\
\text { U.S. Geological Survey station identification number } \\
\text { Date of sample collection (mm/dd/yyyy) }\end{array}$ & $\begin{array}{c}27 \\
\text { Trip blank } \\
\text { 385229104223601 } \\
05 / 22 / 2013\end{array}$ & $\begin{array}{c}26 \\
\text { Trip blank } \\
385246104262201 \\
06 / 05 / 2013\end{array}$ & $\begin{array}{c}21 \\
\text { Trip blank } \\
385354104323901 \\
06 / 12 / 2013\end{array}$ & $\begin{array}{c}16 \\
\text { Equipment blank } \\
385530104270601 \\
06 / 19 / 2013\end{array}$ & $\begin{array}{c}16 \\
\text { Trip blank } \\
385530104270601 \\
06 / 19 / 2013\end{array}$ & $\begin{array}{c}11 \\
\text { Equipment blank } \\
385630104343901 \\
06 / 26 / 2013\end{array}$ & $\begin{array}{c}11 \\
\text { Trip blank } \\
385630104343901 \\
06 / 26 / 2013\end{array}$ \\
\hline \multicolumn{8}{|l|}{ Alkalinity, water, dissolved, field (mg/L as $\left.\mathrm{CaCO}_{3}\right)$} \\
\hline Calcium, dissolved $(\mathrm{mg} / \mathrm{L})$ & & & & 0.047 & & 0.065 & \\
\hline Magnesium, dissolved (mg/L) & & & & $<0.011$ & & $<0.011$ & \\
\hline Sodium, dissolved $(\mathrm{mg} / \mathrm{L})$ & & & & $<0.06$ & & $<0.06$ & \\
\hline Potassium, dissolved $(\mathrm{mg} / \mathrm{L})$ & & & & $<0.03$ & & $<0.03$ & \\
\hline Sulfate, dissolved $(\mathrm{mg} / \mathrm{L})$ & & & & $<0.09$ & & $<0.09$ & \\
\hline Chloride, dissolved $(\mathrm{mg} / \mathrm{L})$ & & & & $<0.06$ & & $<0.06$ & \\
\hline Fluoride, dissolved (mg/L) & & & & $<0.01$ & & $<0.01$ & \\
\hline Silica, dissolved (mg/L) & & & & $<0.06$ & & $<0.06$ & \\
\hline Nitrite, dissolved $(\mathrm{mg} / \mathrm{L})$ & & & & $<0.001$ & & $<0.001$ & \\
\hline Nitrite plus nitrate, as nitrogen $(\mathrm{mg} / \mathrm{L})$ & & & & $<0.04$ & & $<0.04$ & \\
\hline Ammonia, dissolved $(\mathrm{mg} / \mathrm{L})$ & & & & 0.01 & & $<0.01$ & \\
\hline Orthophosphate, dissolved (mg/L) & & & & $<0.004$ & & $<0.004$ & \\
\hline Iron, dissolved $(\mu \mathrm{g} / \mathrm{L})$ & & & & $<4$ & & 9.1 & \\
\hline Manganese, dissolved $(\mu \mathrm{g} / \mathrm{L})$ & & & & 0.44 & & 0.82 & \\
\hline Acetone $(\mu \mathrm{g} / \mathrm{L})$ & $<1.6$ & $<1.6$ & $<1.6$ & & $<1.6$ & & $<1.6$ \\
\hline Benzene $(\mu \mathrm{g} / \mathrm{L})$ & $<0.04$ & $<0.04$ & $<0.04$ & & $<0.04$ & & $<0.04$ \\
\hline Diisopropyl ether $(\mu \mathrm{g} / \mathrm{L})$ & $<0.044$ & $<0.044$ & $<0.044$ & & $<0.044$ & & $<0.044$ \\
\hline Ethylbenzene $(\mu \mathrm{g} / \mathrm{L})$ & $<0.032$ & $<0.032$ & $<0.032$ & & $<0.032$ & & $<0.032$ \\
\hline Methyl acetate $(\mu \mathrm{g} / \mathrm{L})$ & $<0.46$ & $<0.46$ & $<0.46$ & & $<0.46$ & & $<0.46$ \\
\hline Methyl tertiary butyl ether $(\mu \mathrm{g} / \mathrm{L})$ & $<0.06$ & $<0.06$ & $<0.06$ & & $<0.06$ & & $<0.06$ \\
\hline Methyl tert-pentyl ether $(\mu \mathrm{g} / \mathrm{L})$ & $<0.044$ & $<0.044$ & $<0.044$ & & $<0.044$ & & $<0.044$ \\
\hline $\mathrm{m}-+\mathrm{p}$-Xylene $(\mu \mathrm{g} / \mathrm{L})$ & $<0.05$ & $<0.05$ & $<0.05$ & & $<0.05$ & & $<0.05$ \\
\hline o-Xylene $(\mu \mathrm{g} / \mathrm{L})$ & $<0.028$ & $<0.028$ & $<0.028$ & & $<0.028$ & & $<0.028$ \\
\hline tert-Amyl alcohol $(\mu \mathrm{g} / \mathrm{L})$ & $<0.6$ & $<0.6$ & $<0.6$ & & $<0.6$ & & $<0.6$ \\
\hline tert-Butyl alcohol $(\mu \mathrm{g} / \mathrm{L})$ & $<0.8$ & $<0.8$ & $<0.8$ & & $<0.8$ & & $<0.8$ \\
\hline tert-Butyl ethyl ether $(\mu \mathrm{g} / \mathrm{L})$ & $<0.046$ & $<0.046$ & $<0.046$ & & $<0.046$ & & $<0.046$ \\
\hline Toluene $(\mu \mathrm{g} / \mathrm{L})$ & $<0.02$ & $<0.02$ & $<0.02$ & & $<0.02$ & & $<0.02$ \\
\hline
\end{tabular}


Table 6. Analysis of replicate samples of major ions, nutrients, and fuel products in groundwater, Upper Black Squirrel primary aquifer, El Paso County, Colorado, 2013.

[mm, month; dd, day; yyyy, year; mg/L, milligrams per liter; $\mu \mathrm{g} / \mathrm{L}$, micrograms per liter; np, not possible to calculate value because of less-than value ; <, less than; RPD, relative percent difference; \% percent; $\mathrm{CaCO}_{3}$, calcium carbonate; m-, meta ; o-, ortha ; p-, pera ]

\begin{tabular}{|c|c|c|c|c|c|c|c|c|c|c|c|c|c|c|c|}
\hline \multirow{2}{*}{$\begin{array}{l}\text { Local identification number } \\
\text { U.S. Geological Survey station identification number } \\
\text { Date of sample collection (mm/dd/yyyy) } \\
\text { Sample type }\end{array}$} & \multicolumn{3}{|c|}{$\begin{array}{c}27 \\
385229104223601 \\
05 / 22 / 2013 \\
\end{array}$} & \multicolumn{3}{|c|}{$\begin{array}{c}26 \\
385246104262201 \\
06 / 05 / 2013\end{array}$} & \multicolumn{3}{|c|}{$\begin{array}{c}21 \\
385354104323901 \\
06 / 12 / 2013\end{array}$} & \multicolumn{3}{|c|}{$\begin{array}{c}16 \\
385530104270601 \\
06 / 19 / 2013\end{array}$} & \multicolumn{3}{|c|}{$\begin{array}{c}11 \\
385630104343901 \\
06 / 26 / 2013\end{array}$} \\
\hline & $\begin{array}{c}\text { Environ- } \\
\text { mental }\end{array}$ & $\begin{array}{l}\text { Repli- } \\
\text { cate }\end{array}$ & $\begin{array}{c}\text { RPD, } \\
\%\end{array}$ & $\begin{array}{c}\text { Environ- } \\
\text { mental }\end{array}$ & $\begin{array}{c}\text { Repli- } \\
\text { cate }\end{array}$ & $\begin{array}{c}\text { RPD, } \\
\%\end{array}$ & $\begin{array}{c}\text { Environ- } \\
\text { mental }\end{array}$ & $\begin{array}{l}\text { Repli- } \\
\text { cate }\end{array}$ & $\begin{array}{c}\text { RPD, } \\
\%\end{array}$ & $\begin{array}{c}\text { Environ- } \\
\text { mental }\end{array}$ & $\begin{array}{c}\text { Repli- } \\
\text { cate }\end{array}$ & $\begin{array}{c}\text { RPD, } \\
\%\end{array}$ & $\begin{array}{c}\text { Environ- } \\
\text { mental }\end{array}$ & $\begin{array}{c}\text { Repli- } \\
\text { cate }\end{array}$ & $\begin{array}{c}\text { RPD, } \\
\%\end{array}$ \\
\hline Alkalinity, water, dissolved, field $\left(\mathrm{mg} / \mathrm{L}\right.$ as $\left.\mathrm{CaCO}_{3}\right)$ & 107 & 107 & 0.0 & 135 & 131 & 3.0 & 123 & 118 & 4.1 & 177 & 174 & 1.7 & 296 & 295 & 0.3 \\
\hline Calcium, dissolved (mg/L) & 39.5 & 39.7 & 0.5 & 35.8 & 35.8 & 0.0 & 57.3 & 58.5 & 2.1 & 48.3 & 50 & 3.5 & 84.5 & 83.8 & 0.8 \\
\hline Magnesium, dissolved (mg/L) & 4.79 & 4.82 & 0.6 & 3.53 & 3.59 & 1.7 & 6.27 & 6.19 & 1.3 & 4.76 & 4.87 & 2.3 & 7.34 & 6.91 & 6.0 \\
\hline Sodium, dissolved $(\mathrm{mg} / \mathrm{L})$ & 42.9 & 44.1 & 2.8 & 50 & 52.1 & 4.1 & 56.5 & 57.7 & 2.1 & 62.5 & 62 & 0.8 & 75.3 & 74.4 & 1.2 \\
\hline Potassium, dissolved (mg/L) & 2.23 & 2.26 & 1.3 & 2.47 & 2.32 & 6.3 & 4.32 & 3.94 & 9.2 & 5.38 & 5.68 & 5.4 & 6 & 5.56 & 7.6 \\
\hline Sulfate, dissolved $(\mathrm{mg} / \mathrm{L})$ & 49.6 & 50.5 & 1.8 & 58.9 & 58.8 & 0.2 & 77.8 & 77.5 & 0.4 & 50.4 & 49.8 & 1.2 & 72.2 & 73.1 & 1.2 \\
\hline Chloride, dissolved (mg/L) & 13.2 & 13.4 & 1.5 & 10.1 & 10.1 & 0.0 & 61.6 & 60.7 & 1.5 & 41.5 & 42.1 & 1.4 & 34.2 & 32.8 & 4.2 \\
\hline Fluoride, dissolved (mg/L) & 0.367 & 0.372 & 1.4 & 0.43 & 0.43 & 0.0 & 0.31 & 0.31 & 0.0 & 0.75 & 0.76 & 1.3 & 0.14 & 0.13 & 7.4 \\
\hline Silica, dissolved $(\mathrm{mg} / \mathrm{L})$ & 30.5 & 29.8 & 2.3 & 30.1 & 30.1 & 0.0 & 31 & 31 & 0.0 & 33 & 34.3 & 3.9 & 36.1 & 36.9 & 2.2 \\
\hline Nitrite, dissolved (mg/L) & $<0.001$ & $<0.001$ & $\mathrm{np}$ & $<0.001$ & 0.002 & np & $<0.001$ & $<0.001$ & $\mathrm{np}$ & 0.008 & 0.005 & 46.2 & 0.004 & $<0.001$ & $\mathrm{np}$ \\
\hline Nitrite plus nitrate, as nitrogen $(\mathrm{mg} / \mathrm{L})$ & 11.8 & 11.8 & 0.0 & 4.68 & 4.65 & 0.6 & 4.91 & 4.97 & 1.2 & 2.35 & 2.39 & 1.7 & 0.05 & $<0.04$ & $\mathrm{np}$ \\
\hline Ammonia, dissolved (mg/L) & $<0.01$ & $<0.01$ & $\mathrm{np}$ & $<0.01$ & $<0.01$ & $\mathrm{np}$ & $<0.01$ & $<0.01$ & $\mathrm{np}$ & 0.045 & 0.035 & 25.0 & 0.169 & 0.163 & 3.6 \\
\hline Orthophosphate, dissolved (mg/L) & 0.051 & 0.05 & 2.0 & 0.049 & 0.053 & 7.8 & 0.039 & 0.039 & 0.0 & 0.02 & 0.023 & 14.0 & 0.008 & 0.009 & 11.8 \\
\hline Iron, dissolved $(\mu \mathrm{g} / \mathrm{L})$ & 12.2 & 13.7 & 11.6 & $<4$ & $<4$ & $\mathrm{np}$ & 4.1 & 5.6 & 30.9 & 11.3 & 11 & 2.7 & 1,660 & 1,580 & 4.9 \\
\hline Manganese, dissolved $(\mu \mathrm{g} / \mathrm{L})$ & 2.31 & 2.31 & 0.0 & $<0.16$ & $<0.16$ & $\mathrm{np}$ & $<0.16$ & $<0.16$ & $\mathrm{np}$ & 95.8 & 67.8 & 34.2 & 707 & 740 & 4.6 \\
\hline Acetone $(\mu \mathrm{g} / \mathrm{L})$ & $<1.6$ & $<1.6$ & np & $<1.6$ & $<1.6$ & np & $<1.6$ & $<1.6$ & np & $<1.6$ & $<1.6$ & np & 3.3 & 3.6 & 8.7 \\
\hline Benzene $(\mu \mathrm{g} / \mathrm{L})$ & $<0.04$ & $<0.04$ & $\mathrm{np}$ & $<0.04$ & $<0.04$ & $\mathrm{np}$ & $<0.04$ & $<0.04$ & $\mathrm{np}$ & $<0.04$ & $<0.04$ & $\mathrm{np}$ & 0.106 & 0.11 & 3.7 \\
\hline Diisopropyl ether $(\mu \mathrm{g} / \mathrm{L})$ & $<0.044$ & $<0.044$ & $\mathrm{np}$ & $<0.044$ & $<0.044$ & $\mathrm{np}$ & $<0.044$ & $<0.044$ & $\mathrm{np}$ & $<0.044$ & $<0.044$ & $\mathrm{np}$ & $<0.044$ & $<0.044$ & $\mathrm{np}$ \\
\hline Ethylbenzene $(\mu \mathrm{g} / \mathrm{L})$ & $<0.032$ & $<0.032$ & np & $<0.032$ & $<0.032$ & np & $<0.032$ & $<0.032$ & np & $<0.032$ & $<0.032$ & np & 0.118 & 0.117 & 0.9 \\
\hline Methyl acetate $(\mu \mathrm{g} / \mathrm{L})$ & $<0.46$ & $<0.46$ & $\mathrm{np}$ & $<0.46$ & $<0.46$ & $\mathrm{np}$ & $<0.46$ & $<0.46$ & $\mathrm{np}$ & $<0.46$ & $<0.46$ & $\mathrm{np}$ & $<0.46$ & $<0.46$ & $\mathrm{np}$ \\
\hline Methyl tertiary butyl ether (MTBE, $\mu \mathrm{g} / \mathrm{L}$ ) & $<0.06$ & $<0.06$ & $\mathrm{np}$ & $<0.06$ & $<0.06$ & $\mathrm{np}$ & $<0.06$ & $<0.06$ & $\mathrm{np}$ & $<0.06$ & $<0.06$ & $\mathrm{np}$ & $<0.06$ & $<0.06$ & $\mathrm{np}$ \\
\hline Methyl tert-pentyl ether $(\mu \mathrm{g} / \mathrm{L})$ & $<0.044$ & $<0.044$ & np & $<0.044$ & $<0.044$ & np & $<0.044$ & $<0.044$ & np & $<0.044$ & $<0.044$ & np & $<0.044$ & $<0.044$ & np \\
\hline $\mathrm{m}$ - + p-Xylene $(\mu \mathrm{g} / \mathrm{L})$ & $<0.05$ & $<0.05$ & $\mathrm{np}$ & $<0.05$ & $<0.05$ & $\mathrm{np}$ & $<0.05$ & $<0.05$ & $\mathrm{np}$ & $<0.05$ & 0.06 & np & 0.59 & 0.61 & 3.3 \\
\hline o-Xylene $(\mu \mathrm{g} / \mathrm{L})$ & $<0.028$ & $<0.028$ & $\mathrm{np}$ & $<0.028$ & $<0.028$ & $\mathrm{np}$ & $<0.028$ & $<0.028$ & $\mathrm{np}$ & 0.032 & 0.03 & 6.5 & 0.208 & 0.206 & 1.0 \\
\hline tert-Amyl alcohol $(\mu \mathrm{g} / \mathrm{L})$ & $<0.6$ & $<0.6$ & $\mathrm{np}$ & $<0.6$ & $<0.6$ & $\mathrm{np}$ & $<0.6$ & $<0.6$ & $\mathrm{np}$ & $<0.6$ & $<0.6$ & np & $<0.6$ & $<0.6$ & $\mathrm{np}$ \\
\hline tert-Butyl alcohol $(\mu \mathrm{g} / \mathrm{L})$ & $<0.8$ & $<0.8$ & $\mathrm{np}$ & $<0.8$ & $<0.8$ & $\mathrm{np}$ & $<0.8$ & $<0.8$ & $\mathrm{np}$ & $<0.8$ & $<0.8$ & $\mathrm{np}$ & $<0.8$ & $<0.8$ & $\mathrm{np}$ \\
\hline tert-Butyl ethyl ether $(\mu \mathrm{g} / \mathrm{L})$ & $<0.046$ & $<0.046$ & $\mathrm{np}$ & $<0.046$ & $<0.046$ & $\mathrm{np}$ & $<0.046$ & $<0.046$ & $\mathrm{np}$ & $<0.046$ & $<0.046$ & $\mathrm{np}$ & $<0.046$ & $<0.046$ & $\mathrm{np}$ \\
\hline Toluene $(\mu \mathrm{g} / \mathrm{L})$ & $<0.02$ & $<0.02$ & $\mathrm{np}$ & $<0.02$ & $<0.02$ & $\mathrm{np}$ & $<0.02$ & $<0.02$ & $\mathrm{np}$ & 0.06 & 0.07 & 15.4 & 0.44 & 0.46 & 4.4 \\
\hline
\end{tabular}


Nitrate loads above background levels were assumed to result from near-surface land use activities and from lateral inflow from adjacent regions of the aquifer. Nitrate $\left(\mathrm{NO}_{3}\right)$ load was considered as a mass balance over a defined region (control volume) by the relation:

$$
\left(\mathrm{NO}_{3}\right)_{\text {total input }}=\left(\mathrm{NO}_{3}\right)_{\text {surface input }}+\left(\mathrm{NO}_{3}\right)_{\text {subsurface input }} \text {, }
$$

where the total nitrate load to the groundwater (total input) was a summation of subsurface transport of nitrate in groundwater from adjacent regions of the aquifer (subsurface input) and local near-surface nitrate loads (surface input) that have reached the water table. Nitrate inputs and outputs were assumed to be in equilibrium. Substituting mass loads of nitrate in the groundwater $\left(\mathrm{NO}_{3}\right)$ that entered an aquifer volume by nitrate concentration multiplied by volume for the subsurface and total inputs, rearranging terms to solve for the surface inputs of nitrate under a targeted land use, and normalizing to the total nitrate load led to the relation for percent nitrate input from surface sources, given as:

$$
\mathrm{NO}_{3} \%_{\text {surface:total inputs }}=100 *\left(1-\frac{\left(\delta_{v}\left[\mathrm{NO}_{3}\right]_{\text {subsurface input }}\right)}{\left[\mathrm{NO}_{3}\right]_{\text {total input }}}\right)
$$

where $\delta_{v}$ is the ratio of water volume that entered the control volume examined from adjacent regions of the aquifer compared to the total volume of water in the control volume. Groundwater that was drawn from the aquifer and later discharged near the land surface for land-use applications was assumed to return to the aquifer, which ignored any changes to evapotranspiration above natural conditions and provided no net effect to the water budget. Moreover, although infiltration of precipitation and surface water provided about 93 percent of the total flow through the aquifer in past investigations, recharge accounted for only a few inches per year (Watts, 1995), and when accumulated over individual land-use parcels, local recharge was substantially less than groundwater flow in the underlying aquifer across most land parcels. The most appropriate value for $\delta_{v}$, effectively a fitting parameter, was a point of uncertainty. For simplicity, conservative (low) estimates of nitrate source inputs were evaluated where the volume of local recharge water was ignored, which assumed $\delta_{v}$ was equal to one. In cases where the source of nitrate will be targeted or where surface inputs are determined negative, higher estimates of surface nitrate inputs can be attained by lowering $\delta_{v}$, which indicates more substantial contributions from surface inputs. Nitrate contributed from other areas was estimated by subtracting 100 percent from the results from equation 2 determined for a specific land use.

Median nitrate concentrations inside and outside of a region containing the majority of historical cropland locations were used to distinguish between nitrate contributions from agricultural and nonagricultural areas. Similarly, comparison of median nitrate concentrations in septic use parcels and nonseptic use parcels in areas outside of the agricultural region, separated from the agricultural region to exclude the effect of agriculture, was used to estimate nitrate contributions from septic use. Remaining nitrate contributions were associated with the other land uses (county, commercial, grazing, and residential). Because of limited available data to eliminate both agricultural and septic influences, nitrate contributions for the other land uses were proportioned by their respective areaweighted median concentrations to account for the remainder of nitrate contributions.

\section{Groundwater Age}

Environmental tracers, such as CFCs, tritium, and other chemical and isotopic substances in groundwater, can be used to determine time since recharge to the aquifer and to interpret recharge sources. Information about the age of groundwater and mixing fraction of post-1950s groundwater can be used to define recharge rates and to refine hydrologic models. Groundwater ages and mixing fraction of post-1950s groundwater were estimated using the USGS software TracerLPM (Jurgens and others, 2012).

Groundwater ages commonly are termed "apparent ages" because the ages are modeled using simplifying assumptions regarding transport processes that may affect the age-dating constituents in the water (Plummer and Busenberg, 1999). The simplest and most common transport assumption in groundwater age dating is to assume piston flow, which assumes that the constituent concentration was not altered by transport processes (such as mixing or dispersion) from the point of entry to the measurement point in the aquifer. Some groundwater ages determined with a piston-flow model may be an oversimplification because mixing and dispersion can occur during groundwater flow. For mixing processes, the simplest case is one where groundwater is conceptualized as a binary mixture of old and young waters; the problem becomes unsolvable if more than two waters mix (Plummer and Busenberg, 1999) because an insufficient number of reliable environmental tracers can be measured in most groundwater samples. When reporting estimates of groundwater age, it is necessary to qualify the age with the model on which it is based. Initial age estimates were based on apparent age assuming piston flow, and in cases in which $\mathrm{CFC}$ and tritium ratios suggested dilution with old water, a binary-mixing model was applied that assumes dilution of a young fraction with old, pretracer water (Plummer and others, 2006). Otherwise, the percentage of young water (mixing ratio) was not reported.

\section{Tritium}

The radioactive isotope of hydrogen, tritium $\left({ }^{3} \mathrm{H}\right)$, was used with CFC data to identify recent groundwater recharge or groundwater mixtures that contain a component of recent water. In water containing tritium, ${ }^{3} \mathrm{H}$ substitutes for a hydrogen $\left({ }^{1} \mathrm{H}\right)$ atom or deuterium $\left({ }^{2} \mathrm{H}\right)$ atom in the water molecule 
and can serve as a tracer because water containing a ${ }^{3} \mathrm{H}$ atom follows the same pathway through the environment as other water molecules (Plummer and others, 1993). The half-life of tritium is 12.32 years. Tritium is measured in picocuries per liter $(\mathrm{pCi} / \mathrm{L})$ or tritium units $(\mathrm{TU} ; 1 \mathrm{TU}=3.19 \mathrm{pCi} / \mathrm{L})($ Lucas and Unterweger, 2000). Atmospheric thermonuclear weapons testing from 1952 to 1964 introduced a large amount of tritium to the atmosphere that was incorporated directly into water molecules of precipitation. Because the concentration of tritium in the atmosphere was high for a relatively short period, its presence in groundwater can identify water that has been recharged since the 1950s or mixtures that contain a fraction of post-1950s water.

\section{Chlorofluorocarbons}

CFCs were used to estimate apparent ages of recently recharged groundwater and the proportion of young (post1940s) groundwater mixed with old (pre-1940s) groundwater. CFCs can provide excellent tracers and dating tools of young water (Busenberg and Plummer, 1992). Groundwater age dating with CFCs is based on Henry's law of solubility, which is the concentration of the gas dissolved in water in equilibrium with air is proportional to the partial pressure of the gas in air (Plummer and Busenberg, 1999). Under favorable conditions, sufficient concentrations of CFC-12, CFC-11, and CFC-113 can dissolve into water and allow dating of groundwater recharged since approximately 1941, 1947, and 1955, respectively. Atmospheric concentrations of CFC-12, CFC-11, and CFC-113 in air peaked in about 2001, 1994, and 1996, respectively. Because of nearly level atmospheric input functions of CFC mixing ratios in the 1990s and early 2000s, it is not possible to resolve modern CFC ages precisely as can be done with waters recharged at earlier periods, when atmospheric concentrations were increasing rapidly (Plummer and others, 2006).

\section{Dissolved Gases}

Groundwater age dating with CFCs is based on gas solubility, which is affected by the recharge temperature, excess air in the water sample, and the elevation at the location of recharge (Plummer and Busenberg, 1999). The recharge temperature is the temperature of the recharge water at the water table during recharge. Dissolved gases of argon (Ar) and nitrogen $\left(\mathrm{N}_{2}\right)$ in groundwater were used to estimate recharge temperature and excess air of the water samples. Methane can be present in groundwater from the decomposition of organic matter and (or) can be an indicator of contamination from oil and gas exploration activities. The potential for groundwater contamination from oil and gas exploration is a topic of interest in the study area, so methane concentrations were also used to provide background data (pre-exploration conditions) in the vicinity of each sampled well.

\section{Logistic Regression}

Logistic regression is a statistical method that can be used to predict the probability of detecting a water-quality constituent above a certain concentration or threshold (Hosmer and Lemeshow, 1989; Kleinbaum, 1994; Helsel and Hirsch, 1992). Logistic regression has been used to relate water-quality data to human and natural explanatory variables (Koterba and others, 1993; Druliner and others, 1996; Nolan and Clark, 1997; Tesoriero and Voss, 1997; Rupert, 1998, 2003). Maps developed from logistic regression are sometimes called probability maps because the results are stated in terms of percent probability of detection (Rupert, 1998, 2003). An advantage of logistic regression over traditional multivariate linear regression is the ability to examine datasets with nondetections.

For this investigation, logistic regression was used to predict the probability of detecting concentrations of nitrate in groundwater greater than or equal to a prescribed threshold of either 2.5 milligrams per liter $(\mathrm{mg} / \mathrm{L})$ considered a lowlevel threshold or $5 \mathrm{mg} / \mathrm{L}$ considered a mid-level threshold, depending on application (SYSTAT Software, Inc., 2004). Nitrate data were converted to binary classifications of " 0 " for concentrations less than specified levels and " 1 " for concentrations greater than or equal to specified levels. Logistic regression returns the probability of a positive binomial outcome in the form:

$$
P=\frac{e^{\left(b_{o}+b x\right)}}{1+e^{\left(b_{o}+b x\right)}}
$$

where

$P \quad$ is the probability of nitrate concentrations exceeding a defined threshold;

$e^{(. .)}$is the exponential function;

$b_{o}$ is a constant; and

$b x \quad$ is a dot product of the slope coefficients $(b)$ and explanatory variables $(x)$ equivalent to $\sum_{i=1}^{n} b_{i} x_{i}$, where $n$ is the number of explanatory variables.

Logistic regression was used with several diagnostic parameters to evaluate model quality. The log-likelihood ratio measures the success of the model as a whole by comparing observed values with predicted values (Hosmer and Lemeshow, 1989, p. 13). The most significant model is the one with the highest log-likelihood ratio, taking into account the number of explanatory variables (degrees of freedom) used in the model. The log-likelihood ratio follows a chisquared distribution, and the computed $p$-value for the overall model indicates whether model coefficients are significant. The smallest $p$-value is often considered the "best" model. A model $p$-value of 0.10 , for instance indicates a probability of 0.90 (90 percent) to reject the null hypothesis of the coefficient equal to zero. As a stand-alone method, an overall 
model $p$-value of the log-likelihood ratio has relatively weak power for model comparison and should be used in tandem with other diagnostic statistical tools. To maintain parsimony in model fit given the limited dataset of only 50 samples, the number of independent variables (degrees of freedom) should not exceed about 5 according to the "10:1 rule" indicating the ratio of samples to explanatory variables (Vittinghoff and $\mathrm{McCulloch}, 2007)$. In practice, the rule may be conservative; a low number of additional explanatory variables can be justified in some cases (Vittinghoff and McCulloch, 2007). The approach adopted during model development was to evaluate whether more than five variables could be statistically supported and improved model fit. The standard error associated with the regression coefficient of each explanatory variable was constrained to be less than 2.0 to limit model error. The $p$-values that measure statistical fits of individual explanatory variables using the Wald statistic were targeted to be less than 0.10 , or equivalently a 90 percent confidence. Conceptually, the $p$-value for the Wald statistic is similar to the $p$-value for the slope of a line used in linear regression.

A measure of model fit in logistic regression is McFadden's rho (rho-squared); a widely accepted measure of predictive power (McFadden, 1974). It is intended to mimic the coefficient of determination $\left(\mathrm{R}^{2}\right)$ used in linear regression. McFadden's rho ranges between 0.0 and 1.0; a value approaching 1.0 corresponds to an ideal, near perfect model while a value approaching 0.0 indicates a poor model. Values of McFadden's rho tend to be smaller than those of the coefficient of determination. Values between 0.20 and 0.40 indicate good model fits; higher values indicate ratings of very good to excellent (SPSS, Inc., 2000; SYSTAT, Inc., 2004). Variance inflation factors were constrained to values less than about 2.5 to reduce multicollinearity, well below 10.0 which is the level of concern indicated by Helsel and Hirsch (1992, p. 306), although variance inflation factors greater than 2.5 may indicate the presence of multi-collinearity (Allison,1991).

The receiver operating characteristics curve (ROC) is a plot that combines measures of sensitivity and specificity used for an interpretation of model fit. The area under the ROC curve, which ranges from zero to one, provides a measure of test accuracy and measure of discrimination (Hosmer and Lemeshow, 1989), with a value of one being a perfect correlation (model). The sensitivity of model fit was calculated as the number of correctly predicted events (nitrate detections) divided by the total number of observed events (SYSTAT Software, Inc., 2004). The specificity of model fit was calculated as the number of correctly predicted reference events (no nitrate detections) divided by the total number of observed reference events. Generally, ROC values between 0.8 and 1.0 are considered excellent or better (Minitab Software, Inc., 2010). In addition, models using the same detection limits were compared using the Akaike information criterion (AIC), which is a measure of the relative quality of statistical models for a given set of data (Akaike, 1974; Burnham and Anderson, 2002). The model with the lowest AIC was considered the "best" model in terms of information. As a final analysis, the percentage of actual detections was plotted with the predicted probability of detections by using a risk calculation, which involves partitioning the observations into 10 decile (equal) groups (SYSTAT Software, Inc., 2004).

Nitrate was the response (target) variable used in the logistic regression analyses. Both natural and human explanatory variables were considered for each logistic regression model to explain the spatial variability of nitrate in groundwater. Spatial data layers of explanatory variables included: aquifer thickness, depths to groundwater, precipitation, distances to streams, distances to aquifer boundaries, distances to basin boundaries, geologic classifications, watertable elevations, land-surface elevation, land uses, septic use, saturated aquifer thickness, soil taxonomy (order and group), and soil properties (average clay and sand content, average bulk density, average porosity, average organic matter, and average saturated hydraulic conductivity). The distance evaluations of selected attributes were determined in ArcGIS using standard proximity functions. Land-surface elevation and hydrography characteristics of the study area were derived from USGS coverages (U.S. Geological Survey, 1999a; U.S. Geological Survey, 1999b). Land-use classifications were derived from coverages provided by El Paso County. Coverages of soil attributes were retrieved from the Soil Survey Geographic database (SSURGO) and summary analyses by Wieczorek (2014).

Each well sampled for nitrate was assigned all attribute values corresponding to the well's location from spatial coverages using ArcGIS. Categories were refined during preliminary tests to see whether relations could be improved. For instance, although wells were randomly selected to represent the study area in an unbiased manner, most of the randomly selected wells used to sample water quality were located within grazing parcels, which cover the majority of the study area, leaving the remaining land use less represented. For one analysis, land-use classifications were combined into three basic categories: (a) all residential lots, (b) grazing, and (c) other land uses. In another analysis, parcels within a defined region were considered "agricultural" regardless of land-use classification while outside of the agricultural region original land-use classifications were retained. The logistic regression models were built by including each explanatory variable (attribute) in the model, evaluating the resulting test statistics, and deciding whether to include or reject the variable. Model validity and accuracy were determined, as described, by evaluating the log-likelihood ratio, McFadden's rho, model sensitivity and specificity, degrees of freedom, multicollinearity, Wald statistics for each independent variable, and where applicable the Akaike information criterion. 


\section{Susceptibility and Vulnerability}

Maps showing the predisposition to groundwater contamination are commonly referred to as maps of groundwater vulnerability or groundwater susceptibility. Different definitions of groundwater vulnerability and susceptibility have been used over the years in applied investigations (National Research Council, 1993; Rao and Alley, 1993; U.S. Environmental Protection Agency, 1993; Vowinkel and others, 1996; Focazio and others, 2002; Gurdak and Qi, 2006). Logistic regression models for predicting the probability of elevated nitrate concentrations as a function of selected environmental and human related variables were developed in this investigation. The statistical outputs were imported to ArcGIS where logistic regression maps were created showing the probability of detecting nitrate in groundwater above specified concentrations.

As defined in this study, susceptibility of groundwater is a function of natural effects, which may include physical characteristics of the aquifer (for example, geology, soil properties, hydraulic gradients, and flow directions) and intrinsic stresses to the hydrologic system (for example, interactions with surface water and precipitation) (Focazio and others, 2002). In this way, susceptibility did not target human effects or specific sources of elevated concentrations, but instead considered physical attributes related to nitrate in groundwater. The vulnerability of a groundwater resource to contamination could depend on physical factors controlling susceptibility, but also contaminant type and source, and human effects such as land use. In practice, decision makers are often faced with a choice of whether to manage a resource based on knowledge of susceptibility or to target more comprehensive and contaminant-specific assessments of vulnerability (Focazio and others, 2002). Results using logistic regression for predicting susceptibility and vulnerability to nitrate in groundwater were synthesized in the section entitled "Susceptibility and Vulnerability to Nitrate" following sections "Groundwater Flow and Historical Trends" and "Groundwater Quality and Groundwater Age," which provided background information for the logistic regression analyses.

\section{Groundwater Flow and Historical Trends}

A baseline assessment of historical groundwater levels was used to understand variations in groundwater quality and groundwater age throughout the aquifer. The dataset of 172 wells used in the evaluation is provided in Appendix 1 (Appendix 1, tables 1-1 to 1-4). Depth to groundwater data were evaluated for the primary aquifer over four decades from 1975 to 2015 (fig. 19). Overall, average and median depths to groundwater have increased from about 14 to 22 meters over 40 years of record when examined over 5-year time periods. Increases in depths to groundwater (declining groundwater levels) were greatest in the first 15-20 years of record beginning from 1975. Locations near the center of the aquifer where saturated thicknesses are greatest likely supported larger declines in the water table (fig. 16). Groundwater declines in the upper reaches of the aquifer where the aquifer was thin, particularly along the margins, caused wells to run dry at some locations (Watts, 1995). Rates of groundwater-level decline have decreased during the last decade as compared to earlier periods; average and median depth to groundwater have remained fairly constant over the last decade, although a small decline in the groundwater level may have continued. If recent multiyear trends continue there will be relatively small declines in the groundwater levels aquifer-wide over the next several years, although local and annual variability will be expected.

A preliminary evaluation of median water-table elevations and groundwater flow directions was performed over the primary aquifer from 2000-2013 (fig. 20). The dataset of 83 wells used in the evaluation is provided in Appendix 1 (Appendix 1, tables 1-5 to 1-6). Results of the kriging interpolation indicate that the mean residual and mean standardized errors were close to zero ( -0.1 and -0.01 , respectively) and the root mean square standardized error was near unity (1.01), which were reasonable outcomes. Average standard error (standard deviation) was about $7 \mathrm{~m}$, which suggests accuracy of the interpolation is within $14 \mathrm{~m}$ for at least 75 percent of locations using two standard errors according to Chebyshev's inequality, depending on the distribution type (Ross, 2014). Water-table elevations span several hundred meters across the aquifer; levels were highest in the northeast part and decreased in a southern direction. The lowest water-table elevations evaluated were in the south-central part of the aquifer about $15 \mathrm{~km}$ south of highway 94 and the town of Ellicott (fig. 20). Groundwater flow was oriented toward the deepest part of the aquifer, where the aquifer is thickest, along the elongate northsouth corridor (fig. 16 and fig. 20). Local variations in groundwater flow directions were substantial in some areas, although flow directions were generally parallel or moderately askew to the stream channels. At the southern end of the aquifer where depth to groundwater was greatest, water-table elevations had less apparent effect by stream channels, as indicated by flow paths diverging from the stream channels.

As a first-order approximation, groundwater typically migrates through the primary aquifer over periods of decades to about a century. Groundwater flow paths and travel times, although not well detailed in past investigations, will depend on spatial variability of recharge as well as human contributions of water returning to the water table, groundwater dynamics while in transit through the aquifer, and locations where groundwater departs from the study area. Baseline calculations based on preliminary findings by Buckles and Watts (1988) and Topper and Horn (2011) suggest travel times from the northern to southern boundaries of the primary aquifer would be about 100 years, on average. Most of the groundwater flow paths will extend over part of the aquifer creating shorter travel times because of local entry points of recharge to the aquifer from direct precipitation, irrigation practices, or local surface water-groundwater connections. For many internal recharge locations, groundwater would travel distances of several kilometers over decadal time frames. 


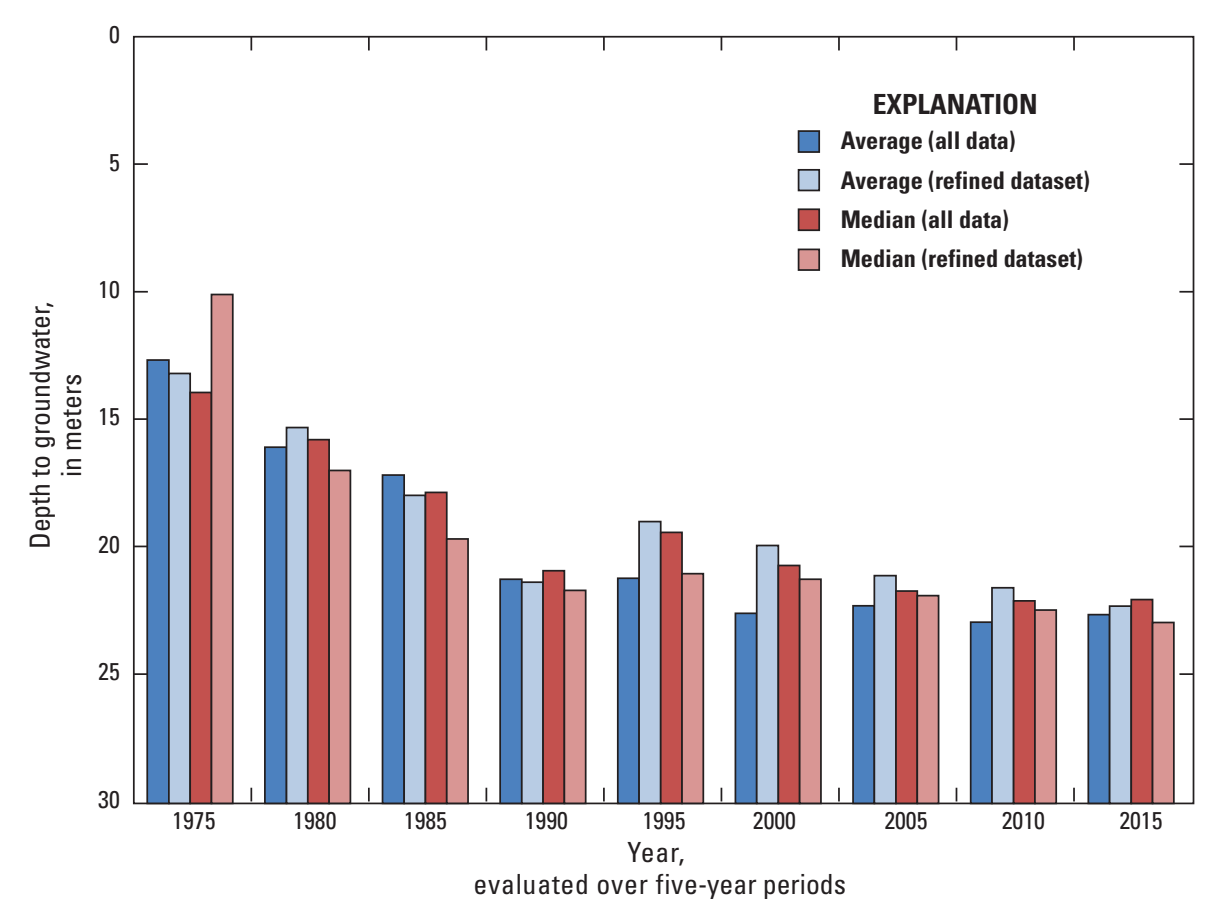

Figure 19. Historical depths to groundwater in the primary aquifer, 1975-2015, Upper Black Squirrel Creek Basin, Colorado. Results are provided using all data and with data refined to sites with observations during at least 7 of 9 (78 percent) of the five-year GSPPETExamined.

Decadal transit times in terms of mitigating groundwater quality imply that mobile and geochemically stable contaminants could attenuate in the aquifer through dilution (flushing) over decadal time frames with measurable changes in land use. Beyond dynamical constraints, residual constituents could complicate observed patterns. Even with an improbable widespread elimination of new nitrogen inputs that are converted to nitrate, a focus of this investigation, nitrogen stored in the soil above the aquifer will continue to enter the aquifer through recharge water, particularly in areas with intensive grazing, development, and agriculture. Nitrate concentrations above background levels will be controlled by nitrogen inputs and stored reserves in the soil, infiltration times to reach the water table, groundwater flow paths and travel velocities, and rates of denitrification which will be slow under oxidized conditions.

Water levels and groundwater flow directions were evaluated together with crop areas (farmland) to define a region where nitrate (fertilizers) may have reached the water table and moved through the aquifer (fig. 21). The "agricultural region" was identified from crop areas produced mainly by circular pivot irrigations systems using land satellite imagery for 1999 , 2006, and 2014 in Google Earth (fig. 21, pink region). The crop areas were visually identified and described based on the resolution of crop outlines at the time of the image. The analysis highlighted that farmed areas have varied over the historical record and that recently irrigated parcels are only one of multiple potential nitrate sources from agricultural use, assuming agricultural land was treated with nitrogen-based fertilizer.

\section{Groundwater Quality and Groundwater Age}

Groundwater quality can be affected by climate, hydrological conditions, geologic sources, human activities, and geochemical processes in the aquifer. The geochemical composition of groundwater is controlled by hydrologic processes and geochemical reactions, including precipitation/dissolution reactions, evaporative concentration, and redox reactions that occur naturally in the unsaturated and saturated zones. Each of these processes, however, can be enhanced by human activities, such as irrigation in agricultural and urban areas. Other human activities such as applying fertilizer and insecticide to agricultural crops or developing oil and gas fields may affect groundwater quality. Dissolved solids in the unsaturated zone are concentrated by evapotranspiration through temporal wetting and drying cycles over annual to millennial time scales (Bauch and others, 2014). As soil water in the subsurface evaporates or is taken up by plants, soluble salts are left behind. As a result, salt, nitrate, and some trace elements and other dissolved constituents accumulate in the unsaturated zone over time (Gurdak and others, 2007; Gurdak and others, 2009). Dissolution of soluble minerals in the unsaturated zone increases the concentration of total dissolved solids in the water. When recharge water from precipitation, irrigation return, recycled waste, and other domestic and municipal sources moves through the unsaturated zone to the water table, reaction with aquifer sediments can further increase the dissolved-solids concentration of water. 


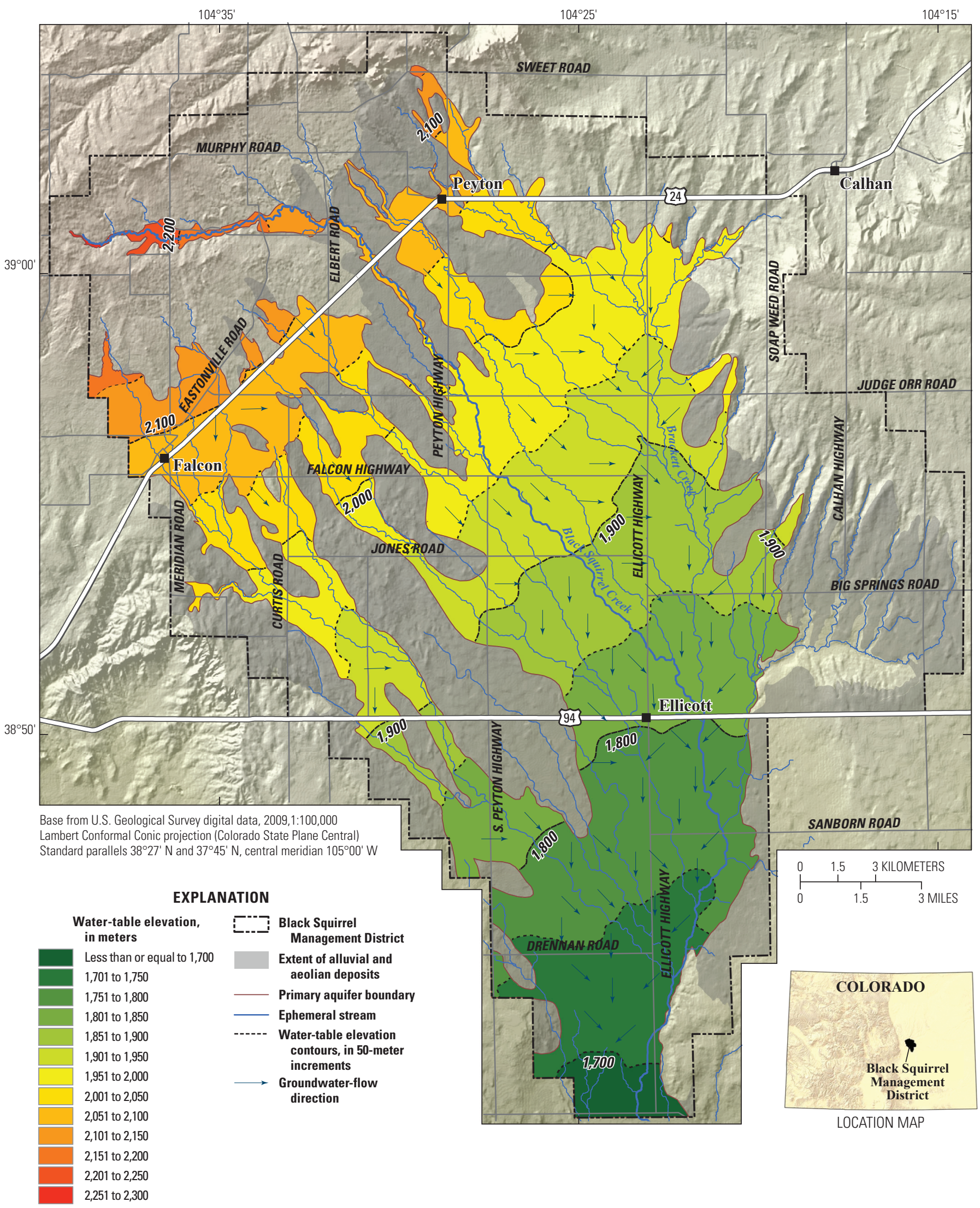

Figure 20. Median water-table elevations and groundwater flow directions in the primary aquifer, 2000-2013, Upper Black Squirrel Creek Basin, Colorado. 


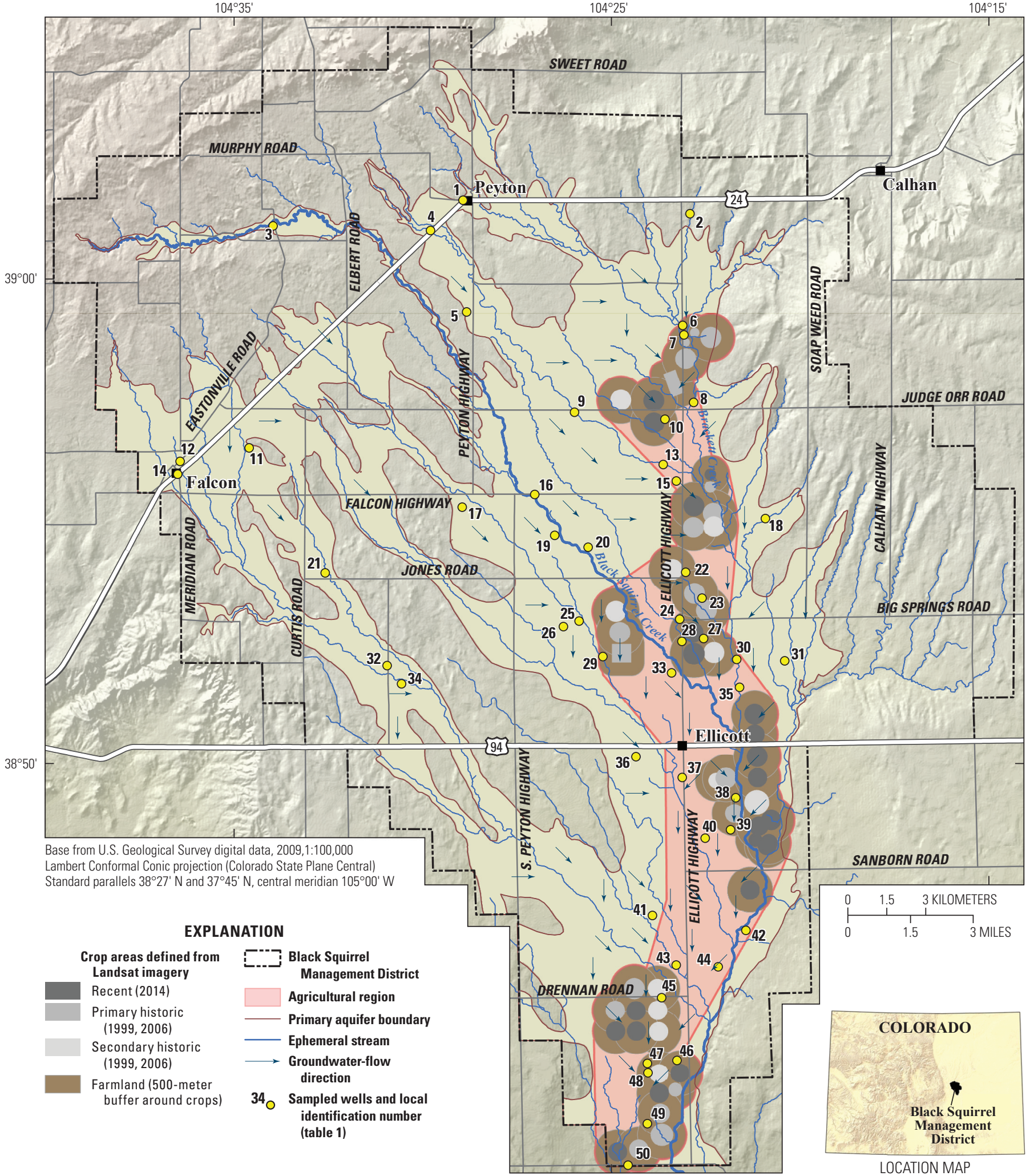

Figure 21. Agricultural region determined using land satellite imagery to define crop areas, 1999-2014, Upper Black Squirrel Creek Basin, Colorado. 
In this study, multiple analyses were used to characterize basic groundwater quality and groundwater age. General site information for the 50 sampled wells is provided in table 1, which includes local identification numbers referenced throughout the report. Spatial distribution of wells by location, well use type, and well depth are provided in figure 22. Groundwater samples were analyzed for major ions, nutrients, fuel products, dissolved gases, CFCs, and tritium. Dissolved gases, major ions, and nutrients provided general information on water quality. CFCs and tritium were used to estimate groundwater age. Groundwater age provided a first order understanding of groundwater movement in the aquifer and provided a separate form of evidence to substantiate geochemical interpretations. The evaluation of fuel products was used to form a baseline of contaminant levels for evaluating potential future oil and gas development.

\section{Data Quality Assessment}

A preliminary step in the water-quality analysis was to evaluate the quality of the chemical data using sample blanks and replicate samples. Replicate samples were collected to assess variability because of the collection and analyses of samples. Equipment blanks were collected to determine if decontamination of the sampling equipment between sites was adequate. Trip blanks were collected to assess the potential for intransit contamination. They accompany the environmental samples to and from the field, never opened, until all samples are readied for analysis. The blank and replicate data indicate that the major-ion, nutrient, and fuel component data were suitable for quantitative analysis of groundwater quality (tables 5 and 6). Concentrations of major ions and nutrients in the equipment blanks were mostly below laboratory reporting levels (table 5). Calcium, ammonia, iron, and manganese were detected in the equipment blanks, but in most cases the concentrations were small; less than 10 percent as a median of environmental samples (table 2). There were no fuel product detections in any of the trip blanks (table 5).

Concentrations of major ions, nutrients, and fuel products detected in environmental samples were comparable to those detected in the replicate samples (table 5). The relative percent difference (RPD) in concentrations between environmental and replicate analyses was compared using the absolute difference between concentrations divided by their average. The RPD of concentrations was small for most analytes; the median RPD of all constituents combined was 2.0 percent, the mean RPD was 4.8 percent, and the standard deviation of RPD was 8.1 percent (table 6). Only 4 constituents had RPDs greater than 20 percent: nitrite, ammonia, iron, and manganese. Nitrite and ammonia had relatively higher RPDs although the magnitudes of differences were small because concentration magnitudes were low. There could be mixed redox conditions by drawing water from different reducing zones in the well screen causing higher RPD in some cases. Overall, these instances were not a concern. Quality assessments confirm the data were suitable for the objectives of the study.

\section{Major lons}

A Piper diagram was used to represent the majorion chemistry of groundwater samples collected from the primary aquifer (fig. 23). Piper diagrams are useful for classifying different water types (Freeze and Cherry, 1979; Piper, 1944). The Piper diagram was used to analyze major-ion chemistry as normalized concentrations in a water sample (expressed in milliequivalents per liter $[\mathrm{meq} / \mathrm{L}]$ from 0 to 100 percent).

Most groundwater can be classified as a blended calcium-sodium bicarbonate type water representative of the primary aquifer (fig. 23, red symbols). Other samples collected from wells located along the periphery of the primary aquifer had cation-anion compositions consistent with multiple water sources, mainly in areas where the alluvial deposits are thin (fig. 16) and geologic contacts to the underlying bedrock aquifers are relatively shallow (fig. 23, green symbols). Interpretation of the Piper diagram shows a linear pattern in the cation proportions from calcium to sodium rich endmembers. Calcium-rich waters identified in wells 3, 12, and 18 located along the western and eastern periphery of the aquifer had major-ion proportions consistent with fresh, shallow groundwater mixing with small to moderate fractions of older groundwater from the underlying bedrock units. Sodium-rich waters identified in wells 4,5 , and 28 in the northern and central parts of the aquifer were consistent with water mainly from the underlying bedrock aquifers (Watts, 1995). Anion proportions did not reveal a clear linear pattern between endmember conditions as in the case of cations, but do indicate changes from bicarbonate-rich water in wells 3 and 4 towards more chloride-rich water in the majority of samples. Major ions reported for well 1 appear to be unique from the other wells, which may be because of local effects related to land use or perhaps drilling artifacts. The classification of groundwater as a distinct mixture of waters from multiple sources represents different scenarios of mixing in the aquifer, although in the interest of simplicity has been classified as a single type of mixed-source groundwater. Moreover, the primary aquifer receives both groundwater that has flowed from areas near the aquifer periphery as well as local water inputs from direct recharge, returned irrigation water, recycled treated septic water, and domestic use water, which mix and become altered geochemically by the in-situ conditions. Thus, the two water types, although separable conceptually, are not mutually exclusive in terms of water sources. 


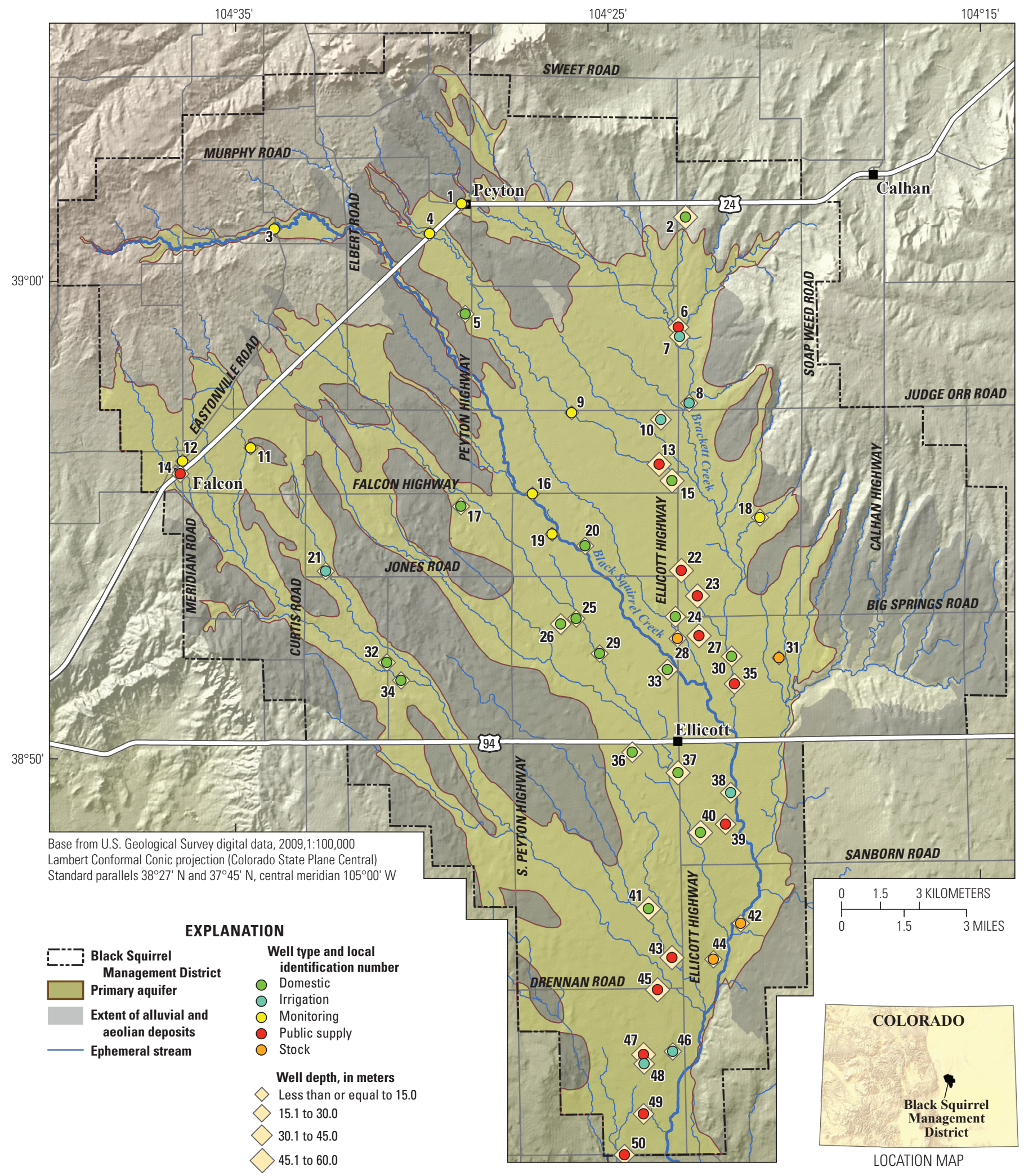

Figure 22. Spatial distribution of the 50 wells sampled for water quality and age, well depth, and well type, Upper Black Squirrel Creek Basin, Colorado. 


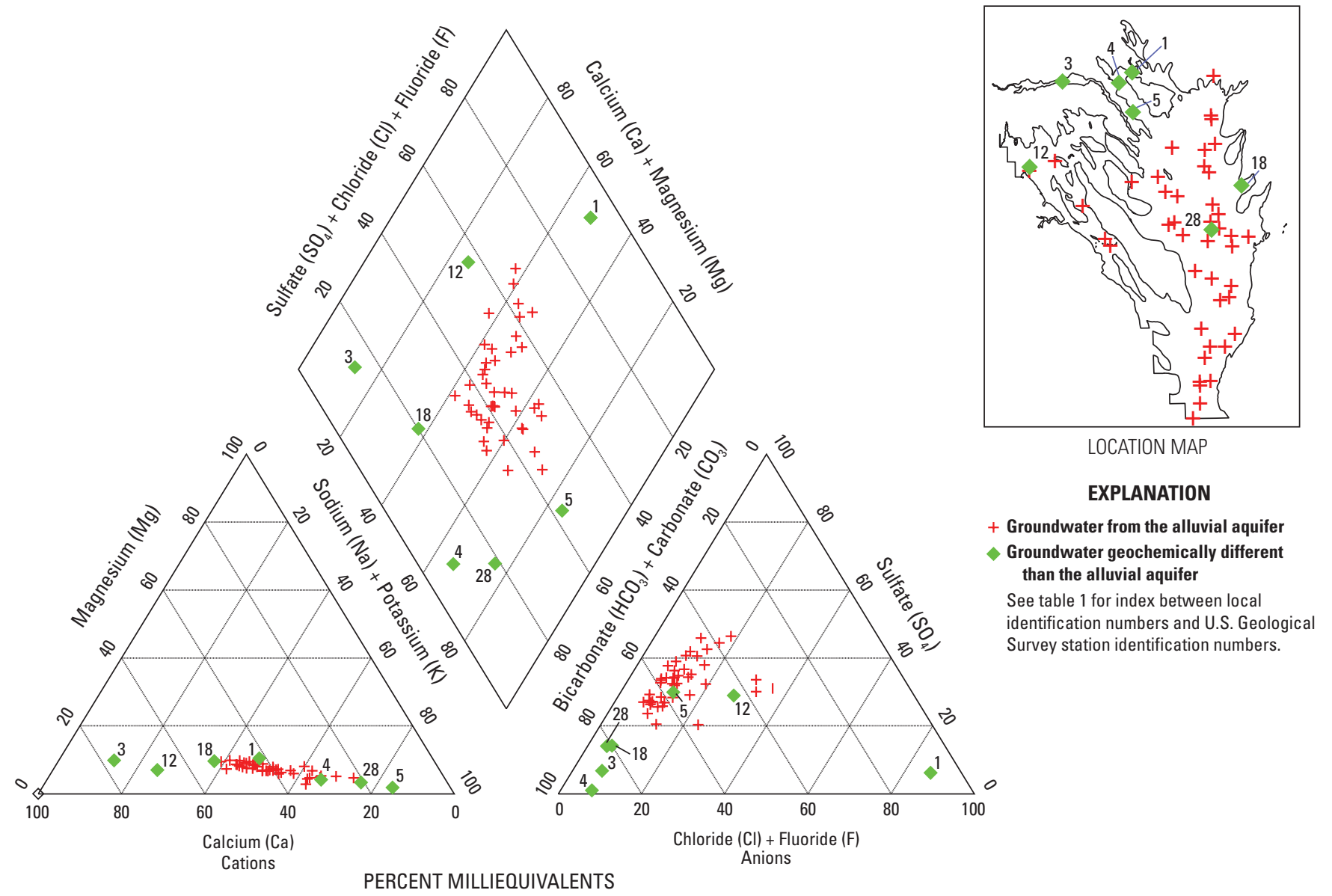

Figure 23. Major-ion chemistry of groundwater samples from the primary aquifer, Upper Black Squirrel Creek Basin, Colorado.

\section{Nutrients}

Drinking-water standards established by the U.S. Environmental Protection Agency (EPA) provide a guide to evaluate water quality (U.S. Environmental Protection Agency, 2009). Primary maximum contaminant levels (MCLs) are legally enforceable standards that apply to public water systems. Primary standards protect public health by limiting the levels of contaminants in drinking water. Secondary maximum contaminant levels (SMCLs) are not direct health concerns but can affect the taste, color, or odor of the water. Only certain constituents have established primary or secondary drinkingwater standards. Groundwater samples were evaluated for several common constituents, including nutrients, and were compared to drinking-water standards where applicable (table 2, primary exceedances shaded in dark gray, secondary exceedances shaded in light gray, standards located at bottom of table). The primary drinking-water standards were exceeded only for nitrate while a few constituents exceeded EPA Secondary Drinking Water Regulations.

Exceedances of the secondary maximum contaminant levels were observed in 20 percent (10 of 50) of the samples or about 6 percent ( 16 of 250 ) of all 5 constituents per sample with established secondary values (table 2). SMCLs were exceeded for $\mathrm{pH}(6.5-8.5)$, chloride $(250 \mathrm{mg} / \mathrm{L})$, iron (300 micrograms per liter $[\mu \mathrm{g} / \mathrm{L}])$, manganese $(50 \mu \mathrm{g} / \mathrm{L})$, and total dissolved solids $(500 \mathrm{mg} / \mathrm{L}): \mathrm{pH}$ analysis showed only 2 exceedances of SMCL; chloride showed only 1 exceedance of SMCL; iron analysis showed only 3 exceedances of SMCL; total dissolved solids showed only 2 exceedances of SMCL; and manganese analysis showed 8 exceedances of SMCL. Five of the nine groundwater samples that exceeded an SMCL for chloride, iron, and (or) manganese were geochemically different than most other samples (fig. 23, well numbers 1, $3,4,12$, and 18). Dissolved solids originate from natural sources, sewage, urban runoff, industrial wastewater, and chemicals used in the water treatment process. Although only two samples contained total dissolved solids at concentrations that exceeded the SMCL of $500 \mathrm{mg} / \mathrm{L}$, several other samples were near the SMCL. Greater exceedances of the SMCL for total dissolved solids could limit use of shallow groundwater as a future source of drinking water or even irrigation supply without costly treatment or blending (Bauch and others, 2014). Water with a concentration of total dissolved solids exceeding $1,000 \mathrm{mg} / \mathrm{L}$ is referred to as "nonfresh." Only well 1 exceeded the "fresh" water threshold for total dissolved solids. 
Common nutrients in fertilizer include nitrogen, phosphorus, and potassium. Nutrients are elements or compounds crucial for animal and plant growth. Measured concentrations of orthophosphate as phosphorous ranged between 0.006 to $0.217 \mathrm{mg} / \mathrm{L}$ in groundwater (table 2). Phosphorous is a limiting nutrient for eutrophication because it is typically in shortest supply (Werner, 2009). Although generally not a concern, water with copious levels of phosphorus can create algal blooms in rivers and streams that may receive groundwater discharge. Measured concentrations of potassium ranged between 0.93 to $12.4 \mathrm{mg} / \mathrm{L}$ in groundwater, which is generally representative of agricultural regions (Domagalski and Johnson, 2012). Nitrate is naturally present in groundwater at low concentrations. Rupert and Plummer (2009) reported that concentrations of nitrate in natural recharge water in the Eagle River Valley of Colorado were less than $1 \mathrm{mg} / \mathrm{L}$ as nitrogen (N). In a national study, Nolan and Hitt (2002) also reported that concentrations of nitrate in groundwater in undeveloped forested areas of the United States were less than $1 \mathrm{mg} / \mathrm{L}$ as N. For this study, nitrate concentrations were greater than $1 \mathrm{mg} / \mathrm{L}$ in water from 44 of the 50 sites sampled (table 2). Nitrate concentrations were greater than the primary maximum contaminant level (MCL) of $10 \mathrm{mg} / \mathrm{L}$ as $\mathrm{N}$ in water from 5 of the 50 sites sampled (10 percent percent), and concentrations were elevated above half of the MCL of $5 \mathrm{mg} / \mathrm{L}$ in water from 27 of the 50 sites sampled (54 percent percent) sampled, which included samples above $10 \mathrm{mg} / \mathrm{L}$. By comparison, concentrations of nitrate in deep drinking-water wells in the Denver Basin exceeded the MCL in only 1 percent of samples, although when considering only alluvial and shallow bedrock monitoring wells the frequency of exceeding the MCL was 18 percent (Musgrove and others, 2014), which is nearly double the observed frequency of nitrate exceedances in the present study.

Nitrate is the primary constituent of interest in managing groundwater quality in this study area because regulated MCLs have been exceeded at some locations in the aquifer. Nitrate concentrations in groundwater are controlled by nitrogen inputs and redox conditions in the aquifer. Once nitrate has entered the groundwater, it can only be removed naturally by denitrification, a process that reduces nitrate to nitrogen gas, or discharge to surface water. The amount of dissolved oxygen in groundwater has a substantial effect on geochemical reactions in the subsurface and on water quality. Denitrification occurs when the groundwater is anoxic (generally when concentrations of dissolved oxygen are less than $0.5 \mathrm{mg} / \mathrm{L}$ ) (McMahon and Chapelle, 2008), whereas nitrate is stable under oxic conditions. Bauch and others (2014) redefined oxic groundwater as having dissolved-oxygen concentrations greater than or equal to $2 \mathrm{mg} / \mathrm{L}$. Regardless of whether dissolved-oxygen concentrations greater than $0.5 \mathrm{mg} / \mathrm{L}$ or $2.0 \mathrm{mg} / \mathrm{L}$ were considered, groundwater in the primary aquifer was generally oxic; dissolved-oxygen concentrations exceeded $0.5 \mathrm{mg} / \mathrm{L}$ in 95 percent of reported values (40 of 42 samples) and exceeded $2.0 \mathrm{mg} / \mathrm{L}$ in 90 percent of reported values $(38$ of 42 samples). Only three samples showed excess nitrogen of 1 to $4 \mathrm{mg} / \mathrm{L}$ from denitrification (table 3, Excess nitrogen). Under oxidized conditions, nitrate can exist in groundwater for many years. For instance, the High Plains aquifer has mostly oxidized geochemical conditions; McMahon and others (2007) estimate that it could take between 250 and 14,000 years for nitrate concentrations in the High Plains aquifer to decrease by $1 \mathrm{mg} / \mathrm{L}$. Although there are no estimates of actual denitrification rates in the primary aquifer, the oxidized conditions observed in most areas indicate that nitrate from fertilizers and animal or human waste could persist for decades or longer.

The spatial distribution of nitrate concentrations in groundwater showed a general pattern of higher concentrations toward the central part of the basin and lower concentrations along stream channels and within the northwest section (fig. 24). Wells in the northwest part of the aquifer had generally low nitrate concentrations (less than $5.0 \mathrm{mg} / \mathrm{L}$ ). Wells 1 and 2 at the northern tip of the study area were selected to fill existing data gaps but produced surprisingly higher nitrate concentrations than wells in the northwest part. A possible factor that may have affected well 1 is its proximity to the town of Peyton, which has sports fields, housing, and other developments; well 1 showed considerable levels of total dissolved solids and chloride not observed in other wells. Local infrastructure such as septic use or other forms of nutrient loading may also have affected water quality in well 1 . Well 2 located near a local housing development at the basin periphery was drilled through the alluvium and into bedrock given the reported well depth and estimated alluvial thickness of nearby areas (Topper, 2008) and may draw substantial portions of water from different aquifers (figs. 16 and 22). Also, wells 1 and 2 are located near (well 1) or outside of (well 2) the primary aquifer boundary where external effects may affect water quality, adding further uncertainty to the representativeness of the samples on reporting typical water quality in the northern part of the aquifer.

Additional areas of the aquifer with low concentrations of nitrate in groundwater were located along Black Squirrel Creek and near other ephemeral streams. Some of the highest concentrations of nitrate were observed near agricultural crops (well numbers 6, 23, 27, 39, 46, 47, and 48), although high nitrate was also observed in other areas (well numbers 15, 35, and 40) within the agricultural region where direct sources could not be identified (fig. 21). Concentrations of nitrate in groundwater within the agricultural region were usually above $5.0 \mathrm{mg} / \mathrm{L}$. Except for well 1, an outlier, the agricultural region contained all sample locations with concentrations of nitrate in groundwater above the primary drinking-water standard (MCL of $10 \mathrm{mg} / \mathrm{L})$.

\section{Dissolved Gases}

Dissolved-gas samples were collected from each well; samples were analyzed for Argon (Ar), carbon dioxide $\left(\mathrm{CO}_{2}\right)$, methane $\left(\mathrm{CH}_{4}\right)$, oxygen gas $\left(\mathrm{O}_{2}\right)$, and nitrogen gas $\left(\mathrm{N}_{2}\right)$ 


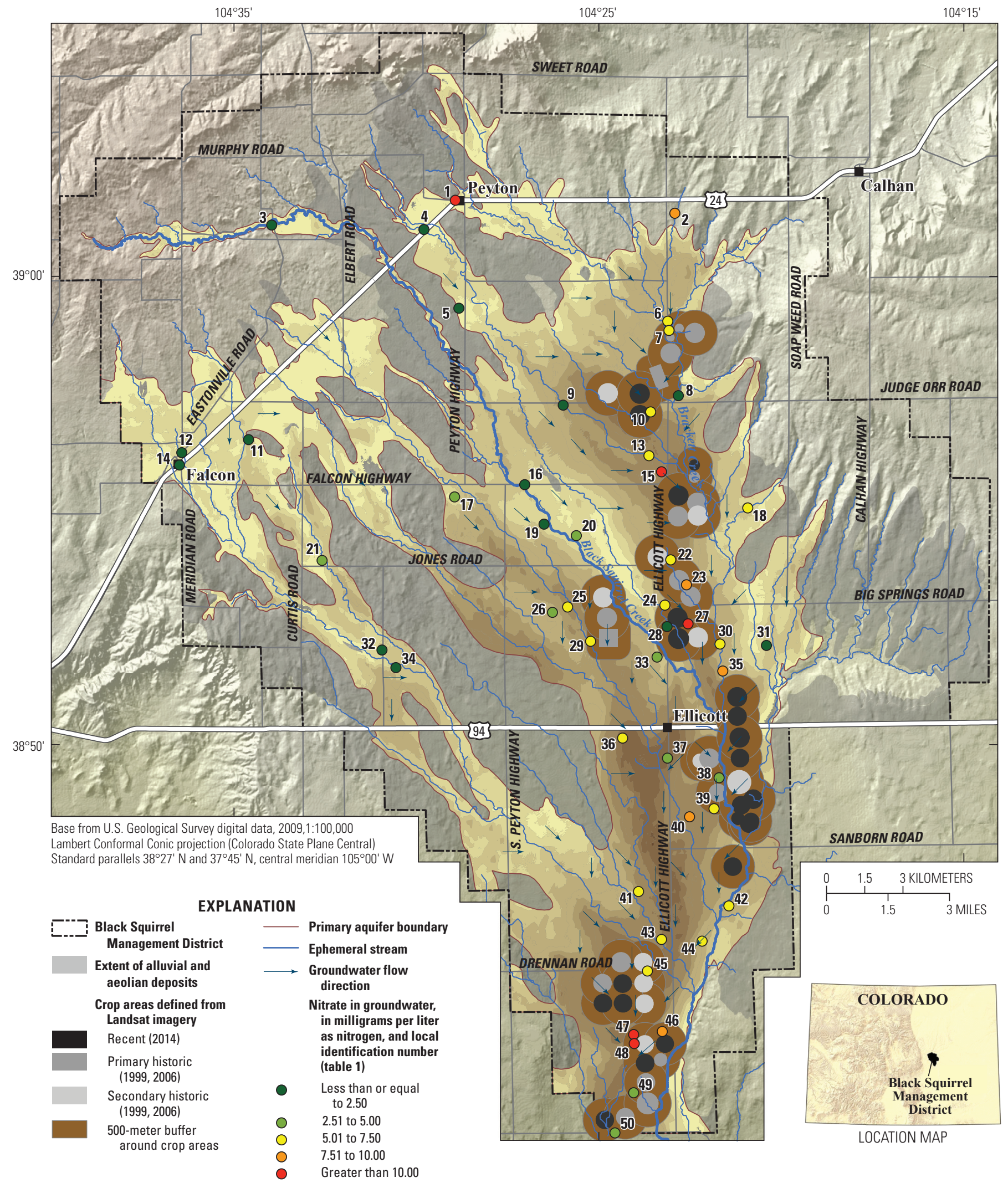

Figure 24. Observed nitrate concentrations at 50 wells within the primary aquifer, Upper Black Squirrel Creek Basin, Colorado. Crop areas primarily from irrigation pivots (fig. 21) and primary aquifer thicknesses (fig. 16, see explanation) have been added for spatial reference. 
(table 3). Most samples contained excess air, probably from excess air being trapped and dissolved in groundwater under increased hydrostatic pressure during rapid recharge conditions. Recharge temperatures calculated from the Ar and $\mathrm{N}_{2}$ data at each site ranged from 6.0 to 15.8 degrees Celsius $\left({ }^{\circ} \mathrm{C}\right)$. Median recharge temperature of all sites combined was $10.7^{\circ} \mathrm{C}$ (table 3 ). Mean and median field water temperatures measured at the time of sampling were about $3.0^{\circ} \mathrm{C}$ higher than the recharge temperatures determined using dissolved gases (table 3), indicating that groundwater likely recharged at lower temperatures than 2013 groundwater temperatures.

Methane $\left(\mathrm{CH}_{4}\right)$ was detected in groundwater from 8 sites at concentrations less than $0.5 \mathrm{mg} / \mathrm{L}$ (table 3). Methane is a colorless, odorless, tasteless gas that can be dissolved in groundwater. Potential sources of methane gas to groundwater include decaying organic matter in aquifer materials, landfills, swamps, and improperly constructed gas wells (U.S. Geological Survey, 2006). Methane was detected in groundwater from sites $4,5,7,9,11,12,13$, and 14 , which are all located in the northern and northwestern parts of the study area (fig. 22). It is possible that the methane in groundwater is from mixing with groundwater from the underlying Denver Basin aquifers, which contains methane (Paschke, 2011), although additional analyses are needed to distinguish water types between the bedrock and overlying primary aquifer. Currently (2013) there are no oil and gas exploration activities in the vicinity of the sites which could be a source of methane in the shallow groundwater.

\section{Groundwater Age}

Apparent groundwater age and mixing fractions of young water were estimated from measured concentrations of CFC-11, CFC-12, CFC-113, and tritium in groundwater (table 4). Groundwater ages were estimated using calculations of excess air, recharge temperature, and recharge elevation; and known histories of the concentrations of those tracers in the atmosphere (Plummer and others, 2006). Most groundwater ages and estimates of fraction of young water (percentage of water that recharged the aquifer post-1950s) were determined using two-component ratios derived from CFC-11, CFC-12, CFC-113, and tritium that followed a piston-flow binary-mixing model. Relations between multiple age-tracer ratios were examined for each sample and compared for added assurance of the age estimates. In instances where an age relation could not be attained or showed contradictory results, tritium was examined independently to determine whether young water was present. Old water that predated the 1950s was indicated by tritium levels less than about 0.2 TU. In instances where an age relation could not be attained or showed contradictory results and tritium levels were above $0.2 \mathrm{TU}$ the sample was considered to contain at least some post-1950s water (fig. 25).

Tritium levels in groundwater were above $0.2 \mathrm{TU}$ for 45 of the 50 (90 percent) sites sampled (table 4 ) indicating that at least some modern post-1950s water was present in nearly all locations in the primary aquifer. About 80 percent of the samples had tritium levels greater than $2 \mathrm{TU}$, indicating that the majority of groundwater was recharged after the 1950s, or groundwater mixtures contained a substantial fraction of post1950s water. The mean and median apparent groundwater ages for the young fraction of water in the samples were each about 30 years and the standard deviation was 6 years. The mean and median fractions of young water were about 65 and 71 percent, respectively, and the standard deviation was 29 percent. The old fraction of water in those samples may have originated from mixing with groundwater from deeper geologic formations, or alternatively could be the result of slow groundwater flow paths in the primary aquifer. About 74 percent of the groundwater samples with attainable age calculations had a fraction of young water greater than 50 percent (mostly young water), while the remaining quarter had a fraction of old water greater than 50 percent (mostly old water before 1940).

Conceptually, groundwater is often youngest in areas where recharge enters the water table and oldest at the base of an aquifer near discharge areas. Areas with the greatest natural recharge are in the highest elevation sections of the basin where precipitation is highest. Local areas of pronounced recharge are associated with losing streams, septic discharge, and irrigation return water which allow water from different sources and environments to mix with the local groundwater in the aquifer. After reaching the water table, recharge water becomes groundwater and moves through the aquifer along a flow path, becoming older in the process. In general, groundwater age is a function of the distance and velocity that groundwater has moved through the aquifer.

Apparent groundwater age was often older than 30 years in the north and northwest parts of the aquifer within thin sediment deposits in close contact with the underlying bedrock (indicated by wells 2, 3, 4, 5, 11, and 12) (fig. 25). Well 1 in this area appeared to be affected by modern water (substantial tritium level) distinct from other surrounding wells, supporting that the sample collected from well 1 is not representative of typical groundwater. In moving further south to southeast from the northwest part a few miles, groundwater was younger overall, which contradicted the paradigm of groundwater aging along a flow path. One explanation is that groundwater became younger, on average, as a greater proportion of young water recharging locally to the aquifer had diluted low volumes of older groundwater that arrived from the northwest part. In other areas, groundwater age exceeded 30 years along a thick deposit that extended from the central-west part of the aquifer near Jones Road to perhaps a mile or two south of Highway 94 (indicated by wells 25, 26, 29, and 33, and possibly wells 36 and 37). Older groundwater ages in the area could be the result of deep groundwater rising from the bedrock aquifer, longer travel times in moving to deeper parts of the aquifer, or less modern recharge diluting older groundwater. Further downslope, groundwater that had reached the central part of the aquifer was more variable in age. In areas near stream sections groundwater was often young; however, usually less than 25 years old (indicated by wells 16, 19, 20, 22, 


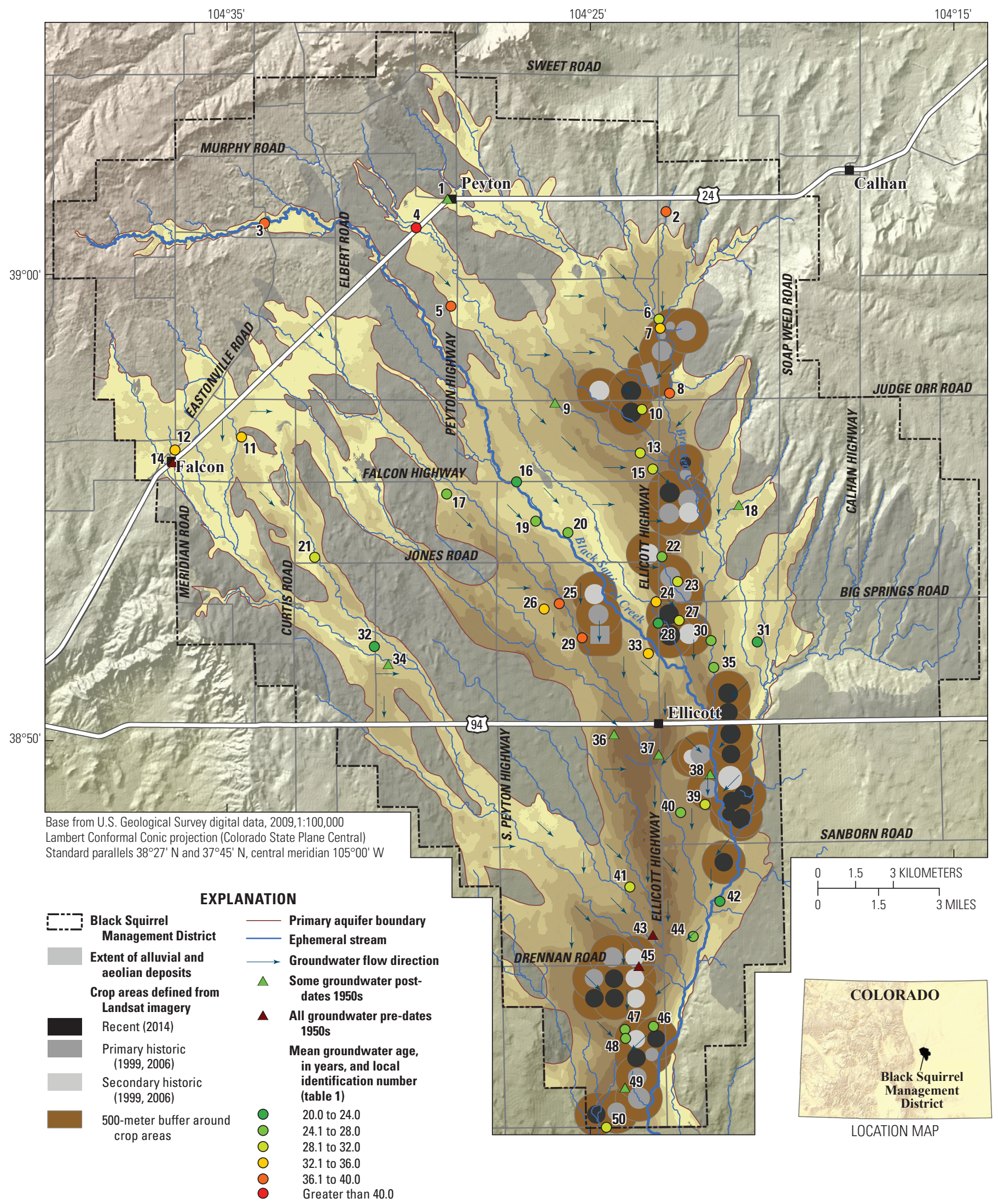

Figure 25. Groundwater age or tritium classification (pre- and post-dates 1950s), Upper Black Squirrel Creek Basin, Colorado. Crop areas primarily from irrigation pivots (fig. 21) and primary aquifer thicknesses (fig. 16, see explanation) have been added for spatial reference. 
$28,30,31,35,42$, and 44). Young groundwater below stream channels could indicate areas of local recharge and supported the conceptual model of losing streams in many parts of the basin. Older bedrock groundwater that may have discharged to the primary aquifer in the north and northwest parts supported the interpretation of geochemically distinct groundwater upwelling into the primary aquifer, evident from the Piper diagram analysis (fig. 23).

\section{Fuel Products}

The fuel products acetone, benzene, diisopropyl ether, ethylbenzene, methyl acetate, methyl tertiary butyl ether (MTBE), methyl tert-pentyl ether, m- + p-xylene, o-xylene, tert-amyl alcohol, tert-butyl alcohol, tert-butyl ethyl ether, and toluene were analyzed in groundwater from 49 of the 50 wells (table 2). Water drawn from 7 of the 49 sites (14 percent) had detections, but all concentrations were below their MCLs. Five of those sites were monitoring wells installed for this report (local identification numbers 3, 4, 9, 11, and 16). There were no obvious point sources of contamination at most of these sites, so it is possible the sites were contaminated by fuel products during installation of the monitoring wells by contract drillers.

\section{Nitrate Trends and Linkages}

Common sources of nitrate in the Upper Black Squirrel Creek Basin include: fertilizers, manure in feedlots and dairies, and sewage and septic effluent (Brendle, 1997). If sufficient precipitation water is applied to the soil and migrates downward, nitrate could leach from the land surface to the underlying groundwater. Increased recharge from rainfall or irrigation can therefore enhance natural rates of nitrate mobilization in semiarid environments. Changes in land use could increase nitrate loads to the aquifer and alter the storage of nitrogen in the soil. For example, when grassland and rangeland have been established but at a later time were converted to agricultural land, excess recharge water from irrigation can flush nitrate that has accumulated naturally in the unsaturated zone down to the water table. Once agricultural land is established, nitrogen-containing fertilizers routinely applied are an additional source of nitrate to shallow groundwater (Gurdak and others, 2009). Further development of septic systems or housing communities could also increase the nitrate loads from effluent that enters the groundwater. Concentrations of nitrate in groundwater will be controlled in part by the amount of nitrogen reaching the aquifer, but geochemical conditions are also important in affecting the stability, and therefore the persistence of nitrate in groundwater.

Historical nitrate concentrations in the primary aquifer were evaluated over nearly three decades from 1985 to 2013 (fig. 26). Data were grouped over 5-year periods from 1985 to 2015, although the data record ended in 2013 coincident with the current study. Median nitrate concentrations were evaluated over the aquifer during multiyear periods because of the irregularity of sampling dates and the spatial and temporal variability of nitrate concentrations. Median nitrate concentrations were considered reliable if at least 30 wells were sampled per 5-year period (fig. 26, dark green bars), whereas periods with less data were considered uncertain and were not used in the evaluation (fig. 26, light green bars). Based on 5 -year periods with sufficient data, median nitrate concentrations increased approximately $1 \mathrm{mg} / \mathrm{L}$ from 4.3 to $5.4 \mathrm{mg} / \mathrm{L}$ over the past 30 years of record; a modest change in comparison to the variability of nitrate concentrations as indicated by the 25 th to 75 th percentiles (fig. 26). Only 8 wells had records in each period, which fell below the minimum 30 well requirement; although, the 8 wells showed a comparable increase in median nitrate concentrations of about $0.8 \mathrm{mg} / \mathrm{L}$ over about three decades (1985 to 2013). In this subgroup, 5 of the 8 wells ( 63 percent) revealed a net increase in nitrate concentrations while the remaining 3 wells had a net decrease in nitrate concentrations, which highlighted local variability in the nitrate levels. Moreover, direct inspection indicates about a 60 percent reduction in the overall increase in median nitrate concentrations from 1995 to 2015 as compared to 1985 to 1995 , perhaps as nitrogen inputs trended closer toward equilibrium with nitrogen exports from the aquifer.

Analyses of nitrate concentrations using nonparametric correlation coefficients from the Kendall Tau-B, Kendall Tau-C, and Spearman rank methods and the parametric correlation coefficient from the Pearson method (Helsel and Hirsch, 1992) show values between about 0.05 and 0.15 , indicating there may have been small annual increases in nitrate over the study area from 1985 to 2013 . Additional analyses were used to test the significance of the predicted annual increases in nitrate. Results from the Kruskal-Wallis test did not differentiate between nitrate distributions evaluated over 5 -year periods with a $p$-value of 0.594 , providing no indication there were significant increases in nitrate beyond expected variability in the data. Moreover, the Mann-Kendall test and seasonal (quarter calendar year) Kendall test used to remove seasonal fluctuations did not indicate significant monotonic trends (increases) in nitrate concentration over time with $p$-values above 0.350 (Helsel and Hirsch, 1992). Although it was recognized from this investigation and according to Brendle (1997) that nitrate concentrations may increase or decrease through time at discrete locations, additional analyses did not show a statistically significant regional increase in nitrate concentration. Given irregularities in the data record, however, the results were interpreted as inconclusive for dismissing the potential for regional changes in nitrate. Additional sampling at established locations and sampling intervals will be needed to determine the reproducibility of the results.

Another important consideration for evaluating nitrate trends is the connection between nitrate inputs and the local water cycle. Sustained inputs of nitrate coupled with continued declines in water-table elevations in the primary aquifer 


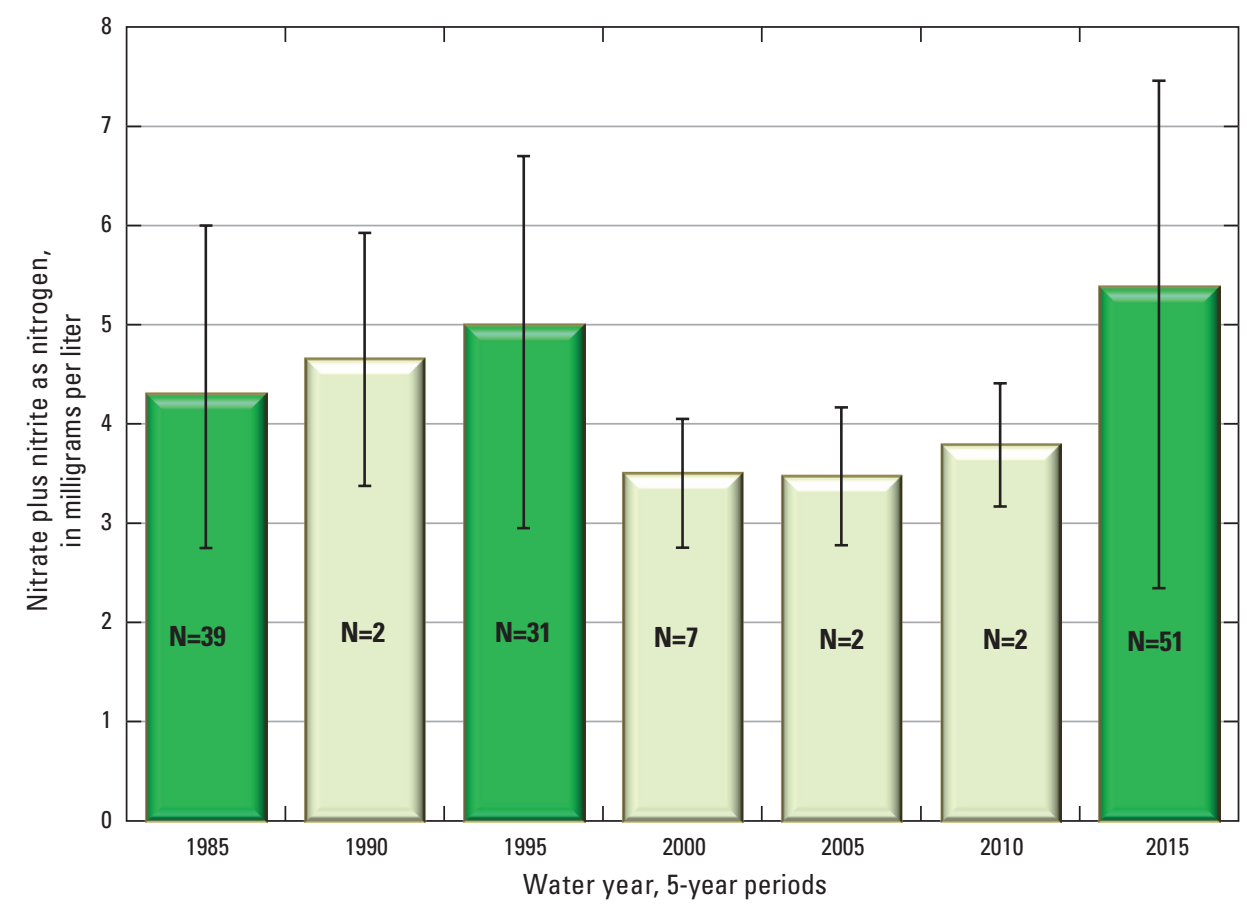

Figure 26. Median nitrate concentrations with 25th to 75th percentile confidence intervals when examined over 5-year periods within the primary aquifer, 1985-2015, Upper Black Squirrel Creek Basin, Colorado. Dark green bars show periods with more reliable estimates using greater than 30 wells ( $\mathrm{N}$ greater than 30 ) with data while the light green bars show periods using few wells with data.

could still lead to changes in water quality. Assuming nitrate loads carried through the recharge water remain unchanged, concentrations in the groundwater could increase depending on the geochemical conditions. Declines in water levels could also reduce flow through the unconsolidated deposits, at least until changes in storage equilibrate. Increased transport times from the land surface through deeper layers of the unsaturated zone to a lower water table could be substantial. Changes in hydraulic conditions could also mobilize deep groundwater into the primary aquifer and degrade water quality (Buckles and Watts, 1988; Watts, 1995). The temporal and spatial relations between water quality and hydrologic conditions should be examined in future work to further characterize the effects of altered hydrologic conditions over the historical record and to examine potential effects from conditions in the future. Aquifer hydrodynamics could play an important role on longterm water quality in the Upper Black Squirrel Creek Basin.

The regional effect of agriculture (irrigated crops) on nitrate concentrations was examined by comparing median concentrations measured inside the defined "agricultural region" to those measured outside the agricultural region (fig. 21). A higher median nitrate concentration was observed for areas inside the agricultural region at $6.7 \mathrm{mg} / \mathrm{L}$ compared to areas outside the agricultural region at $2.3 \mathrm{mg} / \mathrm{L}$, although both median nitrate concentrations were below MCL of $10 \mathrm{mg} / \mathrm{L}$ (fig. 27A). The relation between nitrate concentrations and whether sample locations were in the agricultural region is highly significant with a Mann-Whitney $p$-value of 0.001 . Potential point sources of nitrate from crops were examined within a 500-m buffer of crop areas, defined in the analysis as farmland (figs. 21 and $27 A$ ). The effect of farmland on nitrate concentrations was estimated by comparing median concentrations of samples collected within farmland to those outside of farmland within the defined agricultural region. The analysis showed a higher median nitrate concentration in farmland areas at $6.9 \mathrm{mg} / \mathrm{L}$ compared to areas outside of farmland at $4.6 \mathrm{mg} / \mathrm{L}$ (fig. $27 A$ ). The relation between nitrate concentrations and whether sample locations were located in farmland is strongly significant with a Mann-Whitney $p$-value of 0.015 . Nitrate concentrations in farmland and agricultural areas were generally high and varied less than nitrate concentrations in non-farmland or areas outside of the agricultural region. The effect of septic use on nitrate concentrations was estimated by comparing median concentrations of samples collected within septic parcels located outside of the agricultural region to those in non-septic parcels also located outside of the agricultural region, in order to separate the effect of agriculture. The analysis for septic use showed higher nitrate concentration in septic areas at $4.9 \mathrm{mg} / \mathrm{L}$ compared to nonseptic areas at $1.7 \mathrm{mg} / \mathrm{L}$ with a similar range of values (fig. 27A). The relation between nitrate concentrations and whether sample locations had septic use is significant with a Mann-Whitney $p$-value of 0.052 . 

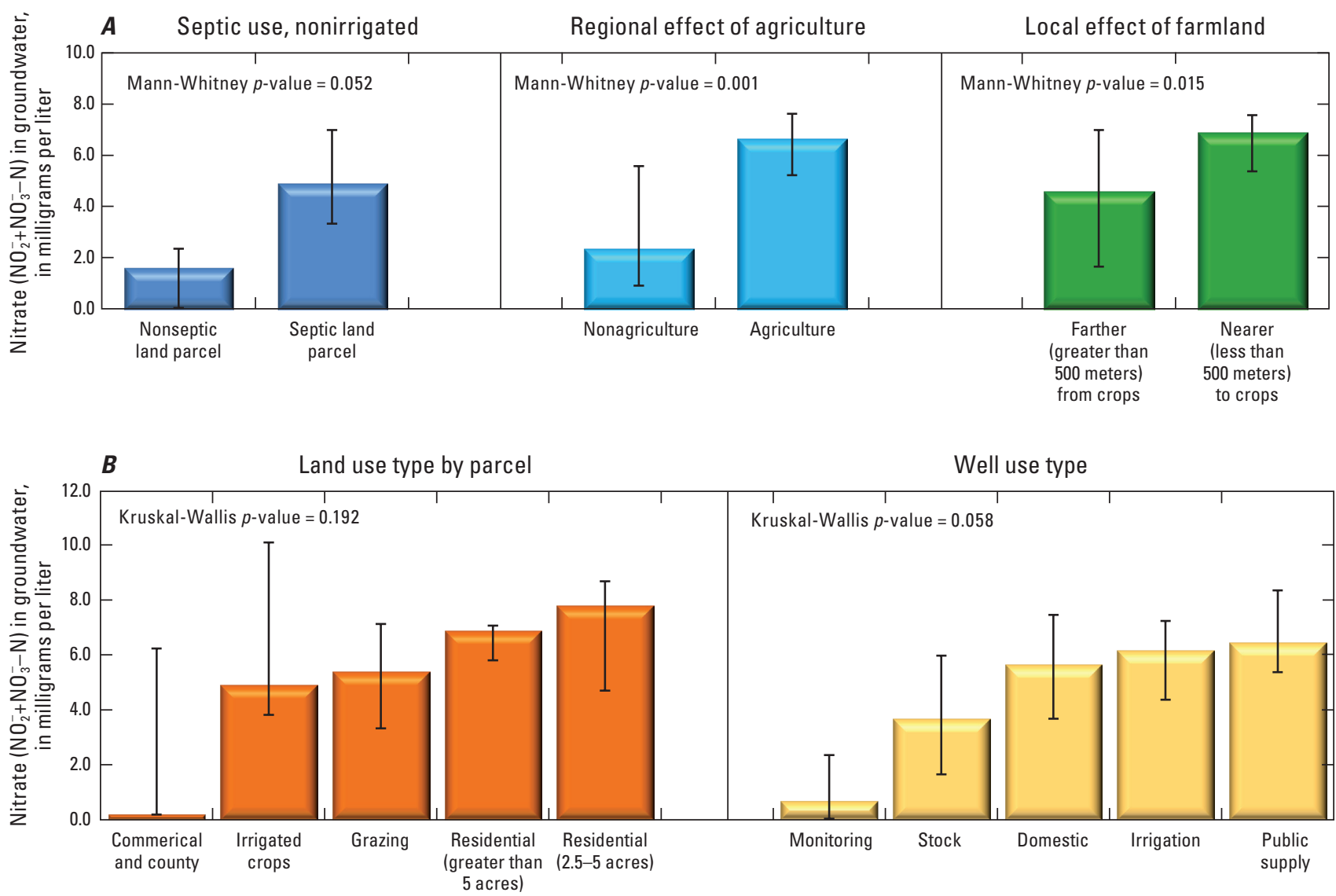

Figure 27. Nitrate concentrations in groundwater attributed to: $A$, septic use, regional effect of agriculture (fig. 21, "Agricultural region"), and farmland (fig. 21, "500-meter buffer around crops"), and $B$, land use and well use type within the primary aquifer, Upper Black Squirrel Creek Basin, Colorado. Bars indicate median (50th percentile) nitrate concentrations and confidence intervals indicate the 25th and 75th percentiles.

Outside the agricultural region, septic systems were the primary driver of nitrate and accounted for an estimated 66 percent of all nitrate sources. The remaining estimated nitrate contributions were 18 percent by grazing, 15 percent by residential use, and 1 percent by agriculture outside of the agricultural region, commercial, and county use combined (fig. 28A). Within the agricultural region, irrigated crops were the primary input of nitrate and accounted for about 65 percent of all nitrate sources (fig. 28B). The importance of irrigated crops on nitrate input occurred even though irrigated parcels accounted for only 3 percent of recent land use by area. Remaining estimated nitrate contributions in the agricultural region were 23 percent by septic systems, 8 percent by grazing, 4 percent by all residential types, and less than 1 (0.1) percent by commercial and county use combined, which included vacant land (fig. 28B). Additional sampling and future modeling could refine and periodically update the estimated contributions.

In terms of overall effect of land use or septic use on nitrate concentration in groundwater, watering crops was the most efficient mechanism delivering nitrate to the groundwater (fig. 28C). Land-use effect defined as percent contribution of nitrate in groundwater divided by percent land area was calculated to be 0.001 for commercial and county (combined), 0.1 for grazing, 0.2 for all residential types, 0.6 for septic systems, and 22.8 for agriculture. The results indicate that future development of agriculture has the greatest potential to affect nitrate levels on a per area basis. Septic use had the second highest effect on nitrate concentrations, but still substantially less than agriculture by a factor of about 0.02 (2 percent of agriculture). Grazing and residential showed comparable levels of nitrate effect below those of septic use. The lowest effect occurred from commercial and county land use. Overall, the strongest effects on nitrate concentrations in groundwater were from agriculture and septic systems. The finding emphasizes that future development of agricultural land and septic use should be considered in future land use planning.

Relations between observed nitrate concentrations and potential explanatory variables that effect nitrate concentrations were examined for well use type and land use (fig. 27B). When distinguished by well use type, the lowest median nitrate concentrations were measured from monitoring wells, 
$\boldsymbol{A} \quad$ Estimated nitrate $\left(\mathrm{NO}_{2}^{-}+\mathrm{NO}_{3}^{-}-\mathrm{N}\right)$ inputs to groundwater outside agricultural region

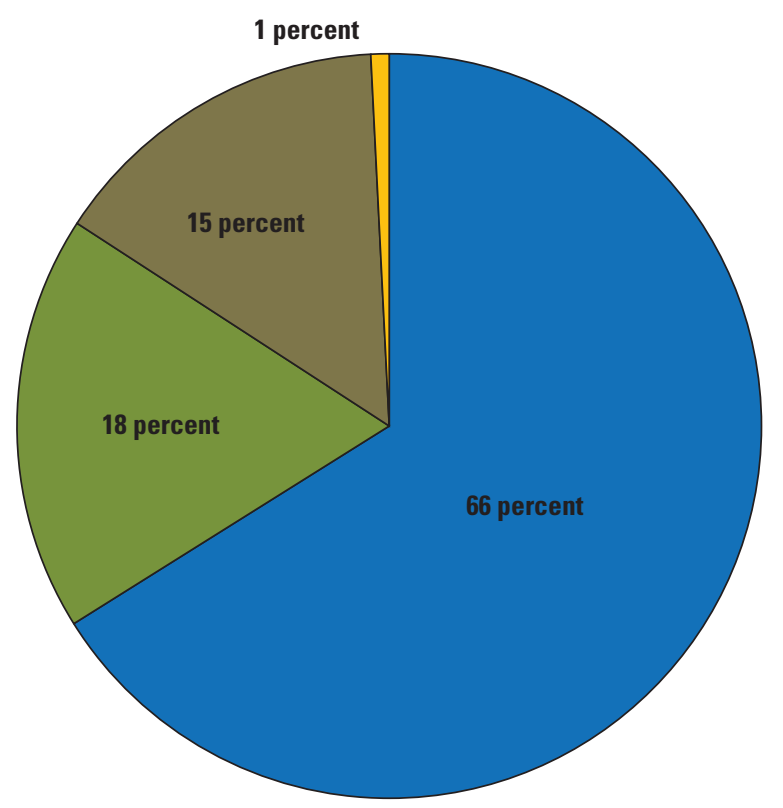

EXPLANATION

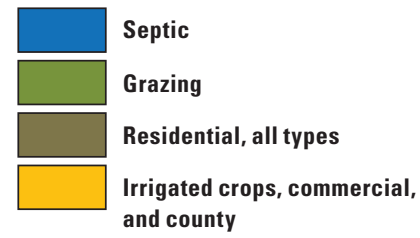

B Estimated nitrate $\left(\mathrm{NO}_{2}^{-}+\mathrm{NO}_{3}^{-}-\mathrm{N}\right)$ inputs

to groundwater inside agricultural region

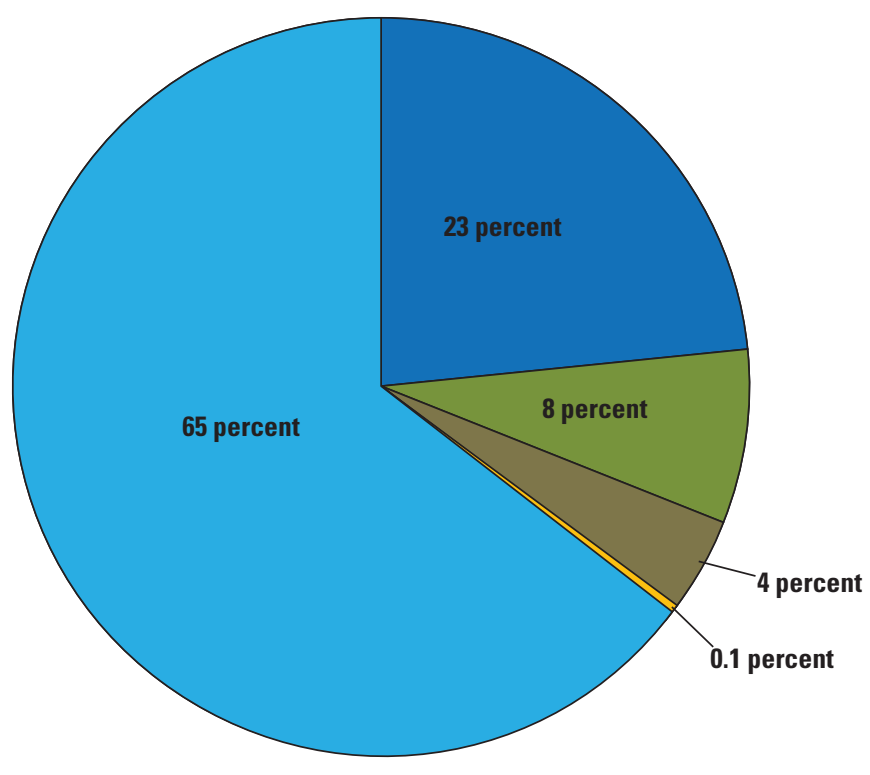

EXPLANATION

Septic

Grazing

Residential, all types

Commercial and county

Irrigated crops

\section{C}

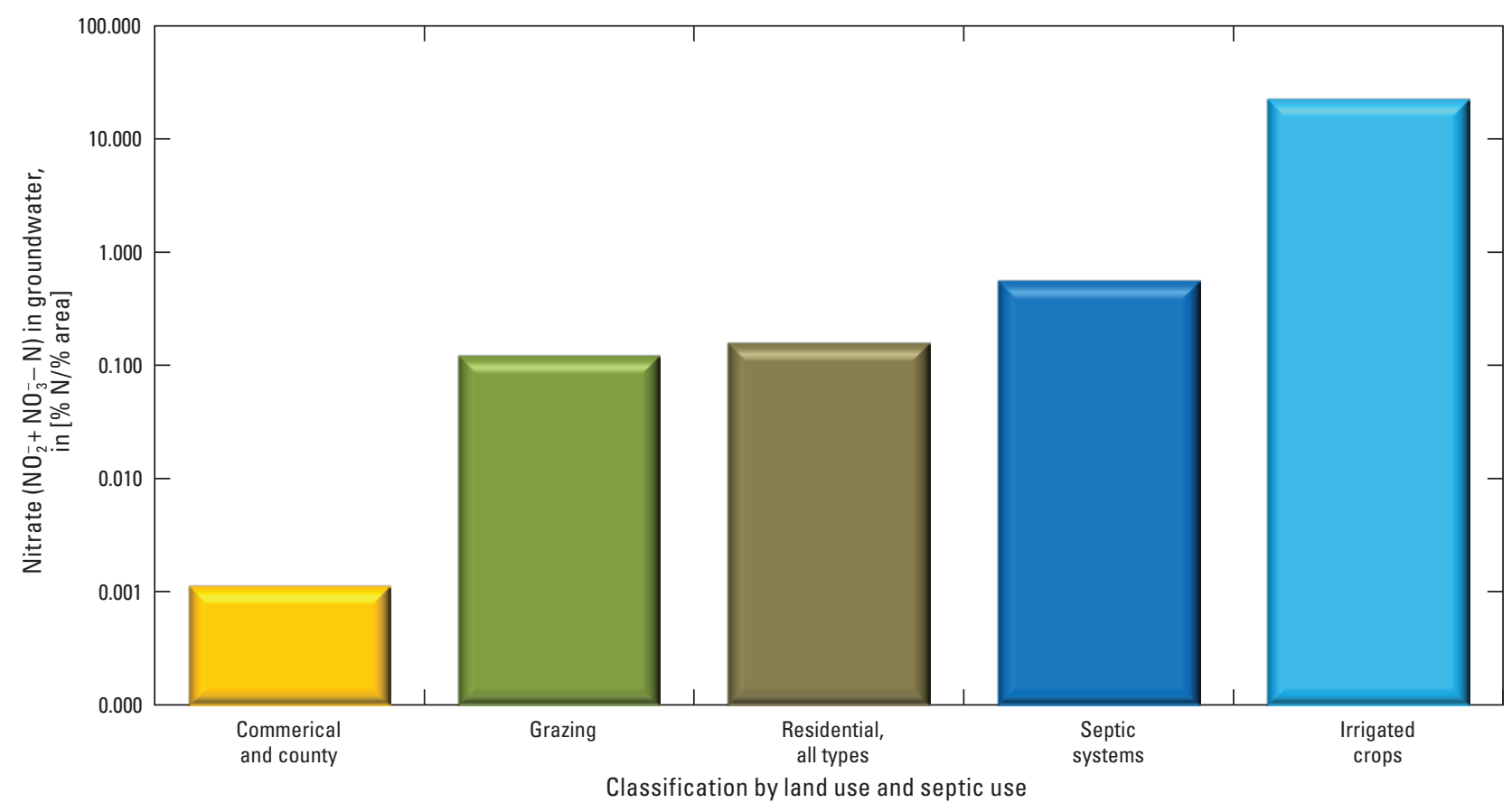

Figure 28. Percentage of nitrate in groundwater contributed by land use and septic use for locations $A$, outside of the agricultural region (fig. 21, "Agricultural region") and $B$, inside of the agricultural region, and $C$, nitrate effect defined as percent nitrate $(\% \mathrm{~N})$ divided by percent area (\% area) per land use within the primary aquifer, Upper Black Squirrel Creek Basin, Colorado. 
located mostly in areas with low nitrate concentrations in the groundwater. For other well use types, stock-supply wells show the lowest median nitrate concentration $(3.7 \mathrm{mg} / \mathrm{L})$, while domestic, irrigation, and public-supply wells were closely related with median nitrate concentrations between $5.6 \mathrm{mg} / \mathrm{L}$ and $6.5 \mathrm{mg} / \mathrm{L}$ (fig. $27 B$ ). The relation between nitrate concentrations and well use type is significant with a KruskalWallis $p$-value of 0.058 . In examining land use, residential lots of 2.5 to 5 acres showed the highest median concentration followed by lots greater than 5 acres at $7.8 \mathrm{mg} / \mathrm{L}$ and $6.9 \mathrm{mg} / \mathrm{L}$, respectively, due in part because many residential lots are located within the agricultural region in areas more vulnerable to nitrate in the groundwater than areas outside of the agricultural region (fig. 27A). Median nitrate concentration in grazing land was $5.4 \mathrm{mg} / \mathrm{L}$ (fig. 27B), which was intermediate among land-use types. Current zonation of land parcels with irrigated crops (fig. 4) showed the second lowest median concentration at $4.9 \mathrm{mg} / \mathrm{L}$ but also indicated high concentrations at some locations and large variability in concentration magnitude (fig. 27B). Commercial and county use had the lowest median nitrate concentrations at $0.2 \mathrm{mg} / \mathrm{L}$ but also revealed large variability in concentration magnitude, possibly indicating multiple effects were present. A strong relation between nitrate concentrations and land use under the proposed categories could not be confirmed with a Kruskal-Wallis $p$-value of 0.192 . Additional sampling will be required to support the results and to target undersampled land uses.

Relations between observed nitrate concentrations and potential explanatory variables were examined across general categories of geology and soil taxonomy (fig. 29). In terms of geologic deposits, distinctions between median nitrate concentrations were moderate ranging from $3.6 \mathrm{mg} / \mathrm{L}$ to $6.3 \mathrm{mg} / \mathrm{L}$, although median nitrate levels under several geologic classifications were similar (fig. 29A). The relations between nitrate concentrations and geologic deposits from interpretations by Scott (1974) and Tweto (1979) are both insignificant with Kruskal-Wallis $p$-values of 0.276 and 0.823 , respectively (fig. 29A). Soil taxonomy (order and group) shows larger distinctions between median nitrate concentrations than geologic types, ranging from $2.8 \mathrm{mg} / \mathrm{L}$ to $7.6 \mathrm{mg} / \mathrm{L}$, depending on the classification scheme considered (fig. 29B). The relations between nitrate concentrations and soil order and soil group (taxonomy) are borderline significant to significant with Kruskal-Wallis $p$-values of 0.104 and 0.034 , respectively.

\section{Susceptibility and Vulnerability to Nitrate}

Logistic regression offers a means for land-use planners and water managers to make informed decisions by considering risk in future planning efforts. Logistic regression models were used to create probability maps showing the likelihood that nitrate concentrations in groundwater exceeded specified levels. A high probability near 1 indicated that encountering nitrate concentrations above a detection level of $2.5 \mathrm{mg} / \mathrm{L}$ (low) or $5.0 \mathrm{mg} / \mathrm{L}$ (moderate) in groundwater was almost certain, while a probability near 0 indicated that detection was unlikely; values between 0 and 1 cover the spectrum of likelihood. Probability maps were generated by combining model parameters with spatial data according to the logistic regression methods, as described in the methods sections "Logistic Regression" and "Susceptibility and Vulnerability." Several analyses of statistical significance and model fit were performed prior to identifying the most representative models, as discussed in the methods sections.

\section{Logistic Regression}

Four types of logistic regression models were developed for aquifer susceptibility and aquifer vulnerability: $A$, mid-level aquifer susceptibility of nitrate concentrations above $5.0 \mathrm{mg} / \mathrm{L}$ using all 50 samples, $B$, low-level aquifer vulnerability of nitrate concentrations above $2.5 \mathrm{mg} / \mathrm{L}$ using all 50 samples, $C$, mid-level aquifer vulnerability of nitrate concentrations above $5.0 \mathrm{mg} / \mathrm{L}$ using all 50 samples, and $D$, mid-level aquifer vulnerability of nitrate concentrations above $5.0 \mathrm{mg} / \mathrm{L}$ using 48 samples, where data from wells 1 and 2 were removed as outliers (table $7 A-D$ ). As detailed in the methods section "Susceptibility and Vulnerability," susceptibility is a measure of relations between natural physical factors and observed nitrate concentrations. Susceptibility reveals how different locations of the aquifer may be prone to nitrate concentrations that exceed specified limits based on natural climatic, geologic, geographic, and hydrologic conditions. Vulnerability is a measure that incorporates relations of susceptibility but also includes human variables, such as land-use zoning and septic use. A nitrate concentration detection limit of $5 \mathrm{mg} / \mathrm{L}$ was used for the susceptibility model and two of the three vulnerability models, which was half of the MCL of $10 \mathrm{mg} / \mathrm{L}$ and about equal to the median nitrate concentration in groundwater sampled during this investigation $(5.4 \mathrm{mg} / \mathrm{L})$. A nitrate concentration of $5 \mathrm{mg} / \mathrm{L}$ in groundwater was considered a mid-level concentration that fell between unknown background concentrations perhaps around $1 \mathrm{mg} / \mathrm{L}$ and the drinking-water standard (MCL) of $10 \mathrm{mg} / \mathrm{L}$. To evaluate low-level nitrate vulnerability above background levels, a concentration of $2.5 \mathrm{mg} / \mathrm{L}$ was selected. Attempts at evaluating nitrate concentrations that exceeded the MCL proved unsuccessful, due primarily because only 5 of the 50 sampled locations ( 10 percent) had nitrate concentrations in excess of $10 \mathrm{mg} / \mathrm{L}$ (table 2), which diminished the reliability of relating nitrate detections above MCL to natural and human explanatory variables.

Natural and human explanatory variables were considered for each logistic regression model using ArcGIS. Spatial data included: aquifer thickness, depths to groundwater, precipitation, distances to streams, distances to aquifer boundaries, distances to basin boundaries, geologic classifications, land-surface elevation, land uses, septic use, saturated aquifer thickness, and soil properties. When examining for aquifer vulnerability, variables recognized as sources of nitrate caused 

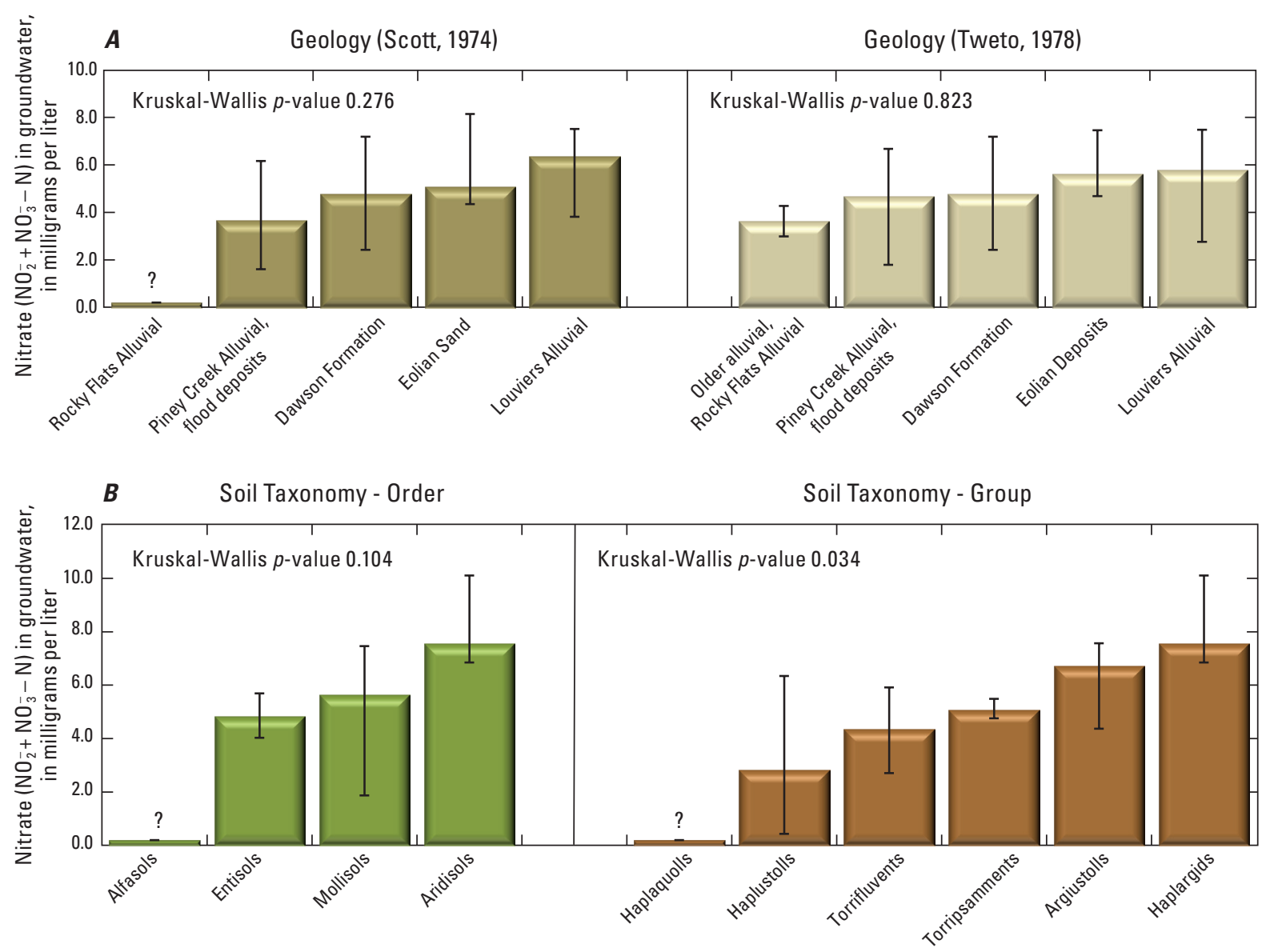

Figure 29. Nitrate concentrations in groundwater categorized by: $A$, geologic classifications by $S$ cott (1974) and Tweto (1979) and B, Soil Survey Geographic database (SSURGO) soil taxonomy (order and group). Bars indicate median (50th percentile) nitrate concentrations and confidence intervals indicate the 25th and 75th percentiles.

by activities determined in the section, "Nitrate Trends and Linkages" were prioritized over other variables with indirect relations to nitrate. Several iterations using automated step wise and manual variable selections were performed by varying initial conditions of the explanatory variables to predict nitrate in groundwater (response variable). Explanatory variables with significant statistical relations to nitrate were used as parameters in the logistic regression models (table 7).

For each parameter, individual $p$-values were targeted to fall below 0.10 . Classes of categorical parameters were permitted to have $p$-values greater than 0.10 in cases where other classes of the categorical parameters showed a significant relation ( $p$-value less than 0.10 ). A parameter could also be included under the circumstances when the $p$-value was near 0.10 and when added to the model overall model fit showed substantial improvement, which occurred only in one instance when examining for aquifer low-level vulnerability (table 7B). For all models, the median $p$-value of the individual model parameters was 0.05 . Standard errors of the regression coefficients given for each model parameter were less than 2.0, not including model coefficients, which was defined as an upper bound of acceptable error. For overall model significances, overall model $p$-values were near zero, which demonstrated each model was significant, overall. Degrees of freedom were targeted to be around 5 given the 50 samples evaluated, following the recommended 1:10 independent variable to explanatory variable ratio. Additional degrees of freedom (variables) were evaluated manually on a caseby-case basis. Additional parameters were retained if model fits could be improved and significances of other variables were maintained. Degrees of freedom in the 4 models ranged from 3 to 7 , which maintained parsimony in model construction (table $7 A-D$ ). Degrees of freedom greater than 5 (6 and 7) were allowed for both mid-level vulnerability models (table $7 C$ and $D$ ). As overall measures of model performance, McFadden's rho averaged 0.4 with a range from 0.3 to 0.5 , which indicated all models were of reasonable quality. Total correct predictions ranged between 68 and 80 percent with an overall average of 76 percent, which was standard outcome in logistic regression and demonstrated most predictions were correct. Receiver operating characteristics (ROC) curve ranged from 0.86 to 0.93 out of a maximum value of 1.0, which showed acceptable levels of test accuracy.

To provide additional support that the nitrate models were sufficiently calibrated, regression analyses were performed between the percentage of elevated nitrate concentrations and 
Table 7. Four logistic regression models showing the probability that nitrate concentrations in groundwater exceeded specified limits with measures of model fits: $(A)$ mid-level aquifer susceptibility of nitrate concentrations above $5.0 \mathrm{mg} / \mathrm{L},(B)$ low-level aquifer vulnerability of nitrate concentrations above $2.5 \mathrm{mg} / \mathrm{L}$, and $(C)$ mid-level aquifer vulnerability of nitrate concentrations above $5.0 \mathrm{mg} / \mathrm{L}$ using all 50 samples, and $(D)$ mid-level aquifer vulnerability of nitrate concentrations above $5.0 \mathrm{mg} / \mathrm{L}$ using 48 samples with data from wells 1 and 2 removed. The respective maps for the four models are shown in figures $31-34$, respectively.

[CV, continuous variable; DV, discrete variable; R, reference variable in categorical data; Combined, simplified land use combining county, commercial, and recently irrigated; All residential, all residential parcels less than 2.5 acres, 2.5 to 5 acres, and greater than $5 \mathrm{acres}$; $\mathrm{mg} / \mathrm{L}$, milligrams per liter; $\mathrm{m}$, meter; $\mathrm{cm}$, centimeter; --, no data for reference parameter; ROC, receiver operating characteristic curve; AIC, Akaike information criterion; Robust, adjusted calculations of standard errors and $p$-values to account for model nonlinearity]

\begin{tabular}{|c|c|c|c|c|c|}
\hline \multicolumn{6}{|c|}{ A, Mid-level susceptibility model (nitrate in groundwater above $5.0 \mathrm{mg} / \mathrm{L}$, all samples) } \\
\hline Model parameters & $\begin{array}{c}\text { Coefficient } \\
\text { estimate }\end{array}$ & $\begin{array}{c}\text { Standard } \\
\text { error }\end{array}$ & $p$-value & $\begin{array}{c}\text { Robust } \\
\text { standard error }\end{array}$ & $\begin{array}{l}\text { Robust } \\
\text { p-value }\end{array}$ \\
\hline Constant & -3.399 & 1.768 & 0.054 & 1.837 & 0.064 \\
\hline Soil organic matter, in percent by weight (CV) & -2.419 & 1.346 & 0.072 & 1.279 & 0.059 \\
\hline Soil water storage to $25-\mathrm{cm}$ depth, as ratio $(\mathrm{CV})$ & 1.601 & 0.748 & 0.032 & 0.761 & 0.035 \\
\hline Measure of model fit & & & Value & & \\
\hline McFadden's rho-squared & & & 0.30 & & \\
\hline AIC & & & 56.4 & & \\
\hline Sensitivity & & & 0.71 & & \\
\hline Specificity & & & 0.66 & & \\
\hline Total correct predictions, ratio & & & 0.68 & & \\
\hline Area under ROC, unit normalized & & & 0.86 & & \\
\hline
\end{tabular}

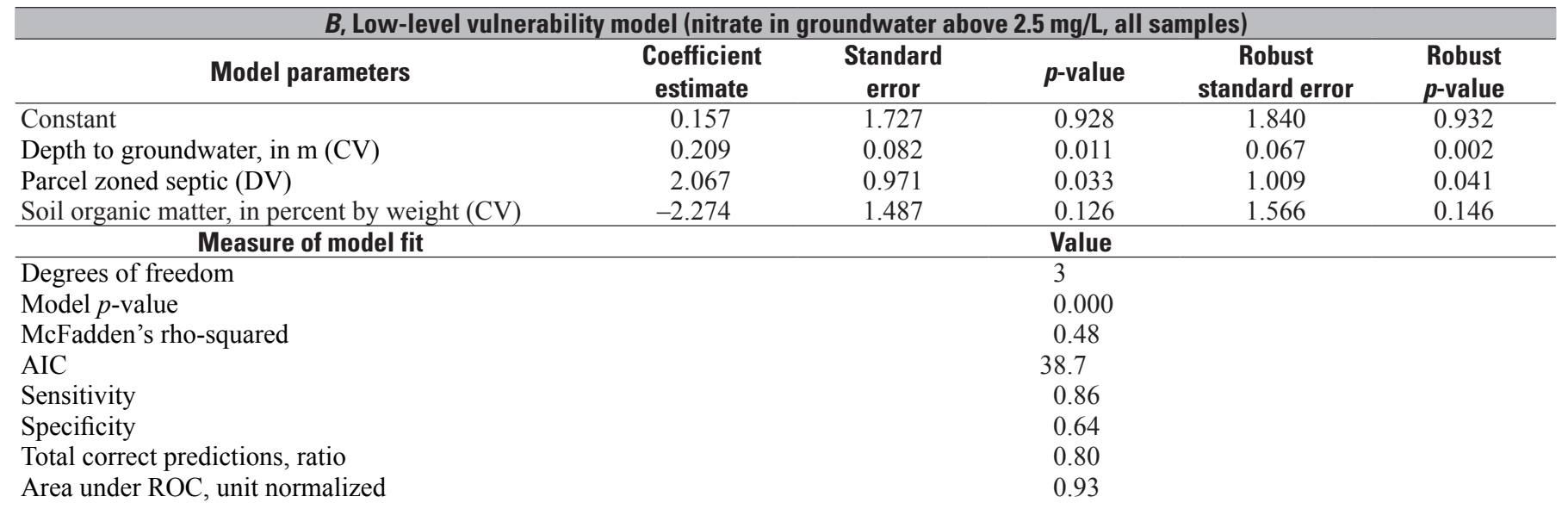

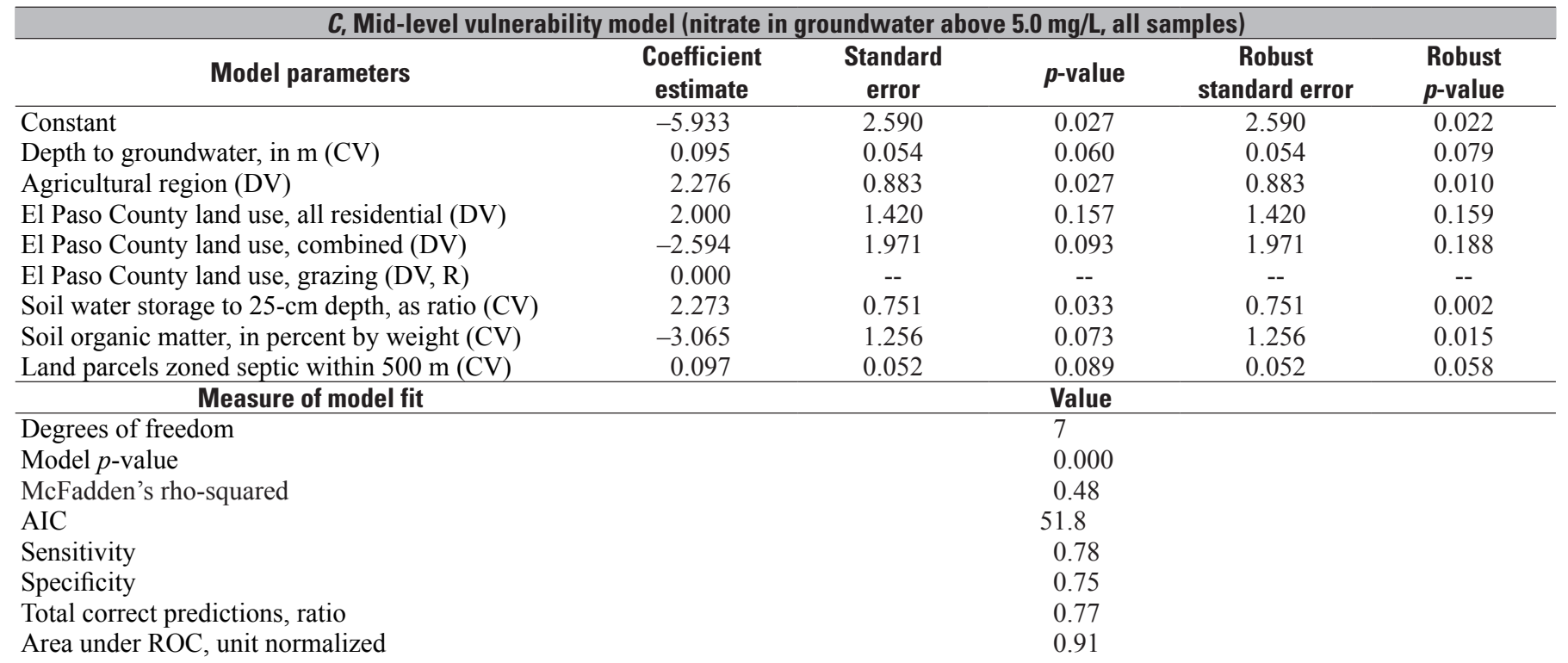


Table 7. Four logistic regression models showing the probability that nitrate concentrations in groundwater exceeded specified limits with measures of model fits: $(A)$ mid-level aquifer susceptibility of nitrate concentrations above $5.0 \mathrm{mg} / \mathrm{L},(B)$ low-level aquifer vulnerability of nitrate concentrations above $2.5 \mathrm{mg} / \mathrm{L}$, and $(C)$ mid-level aquifer vulnerability of nitrate concentrations above $5.0 \mathrm{mg} / \mathrm{L}$ using all 50 samples, and $(D)$ mid-level aquifer vulnerability of nitrate concentrations above $5.0 \mathrm{mg} / \mathrm{L}$ using 48 samples with data from wells 1 and 2 removed. The respective maps for the four models are shown in figures $31-34$, respectively.-Continued

$[\mathrm{CV}$, continuous variable; DV, discrete variable; R, reference variable in categorical data; Combined, simplified land use combining county, commercial, and recently irrigated; All residential, all residential parcels less than 2.5 acres, 2.5 to 5 acres, and greater than $5 \mathrm{acres}$; $\mathrm{mg} / \mathrm{L}$, milligrams per liter; m, meter; $\mathrm{cm}$, centimeter; --, no data for reference parameter; ROC, receiver operating characteristic curve; AIC, Akaike information criterion; Robust, adjusted calculations of standard errors and $p$-values to account for model nonlinearity]

\begin{tabular}{|c|c|c|c|c|c|}
\hline \multicolumn{6}{|c|}{ D, Mid-level vulnerability model (nitrate in groundwater above $5.0 \mathrm{mg} / \mathrm{L}$, two outliers removed) } \\
\hline Model parameters & $\begin{array}{c}\text { Coefficient } \\
\text { estimate }\end{array}$ & $\begin{array}{c}\text { Standard } \\
\text { error }\end{array}$ & p-value & $\begin{array}{c}\text { Robust } \\
\text { standard error }\end{array}$ & $\begin{array}{l}\text { Robust } \\
p \text {-value }\end{array}$ \\
\hline Constant & -6.065 & 2.899 & 0.036 & 2.774 & 0.029 \\
\hline Agricultural region (DV) & 2.388 & 1.062 & 0.025 & 0.841 & 0.005 \\
\hline El Paso County land use, all residential (DV) & 2.643 & 1.454 & 0.069 & 1.378 & 0.055 \\
\hline El Paso County land use, combined (DV) & -2.791 & 1.619 & 0.085 & 2.138 & 0.192 \\
\hline Soil organic matter, in percent by weight (CV) & -3.335 & 1.873 & 0.075 & 1.247 & 0.007 \\
\hline Measure of model fit & & & Value & & \\
\hline Degrees of freedom & & & 6 & & \\
\hline Model $p$-value & & & 0.000 & & \\
\hline McFadden's rho-squared & & & 0.50 & & \\
\hline AIC & & & 47.4 & & \\
\hline
\end{tabular}

the predicted probability of detecting elevated nitrate (fig. 30). The percentage of predicted detections of elevated nitrate was determined by dividing the predicted probabilities for the study areas into deciles, or 10 equal groupings. The percentages of elevated nitrate detections within each group were then calculated and examined using linear regression analysis shown in figure 30 . The nitrate models exhibited good calibration to the percentage of actual detections, with coefficient of determination values of around 0.99 . The models show reasonable fits close to the 1:1 line.

Models using a nitrate concentration limit of $5 \mathrm{mg} / \mathrm{L}$ could be compared using the Akaike information criterion (AIC) to measure the relative quality of each model. AIC values for the susceptibility model and two mid-level vulnerability models were $56.4,51.8$, and 47.4 , respectively (table $7 A, C, D$ ). The model with the lowest AIC considered the "best" model in terms of information was model " $D$ "; mid-level vulnerability to nitrate concentrations above $5 \mathrm{mg} / \mathrm{L}$ using 48 samples with data from outlier wells 1 and 2 removed (table $7 D$ ). Based on the AIC values, the two remaining models were less than 10 percent as probable to minimize information loss, and would be eliminated if only a single model could be selected. In considering McFadden's rho (0.5) and supporting evidence from the Hosmer-Lemeshow statistic (21.5 and $p$-value of 0.003$)$, a similar measure to McFadden's rho, the mid-level vulnerability model with two outliers removed was also the best overall model (table $7 D$ ). In comparing vulnerability results, model " $D$ " was selected as the best model for determining probabilities of detection of mid-level nitrate in groundwater. Moreover, given the lower McFadden's rho, ROC, and AIC values of the susceptibility model (table 7A), it was concluded that natural physical factors do not fully explain nitrate in the groundwater. The low-level vulnerability model (table $7 B$ ) provided supplemental results to the mid-level vulnerability models. The low-level vulnerability model was ranked on par with the best model for mid-level vulnerability when considering ROC, total correct predictions, and McFadden's rho values.

\section{Probability Maps}

Probability maps of susceptibility and vulnerability were generated from the four logistic regression models (figs. 31-34). The susceptibility model considered natural relations between mid-level $(5 \mathrm{mg} / \mathrm{L})$ nitrate concentrations in the groundwater and climatic, hydrologic, and geologic explanatory variables (fig. 31 , table $7 A$ ). Significant variables were identified as depth to groundwater, soil organic matter, and soil water storage to $25-\mathrm{cm}$ depth. Areas in the central part of the primary aquifer had the greatest depths to groundwater and largest saturated thicknesses, and overall higher concentrations of nitrate in the groundwater (fig. 24). The majority of agriculture was also located in the central part, although agriculture was not examined directly when evaluating natural variables in the susceptibility assessment. Areas with greatest soil organic matter were located mainly in the western half of the study area (fig. 10). Areas with highest soil organic 


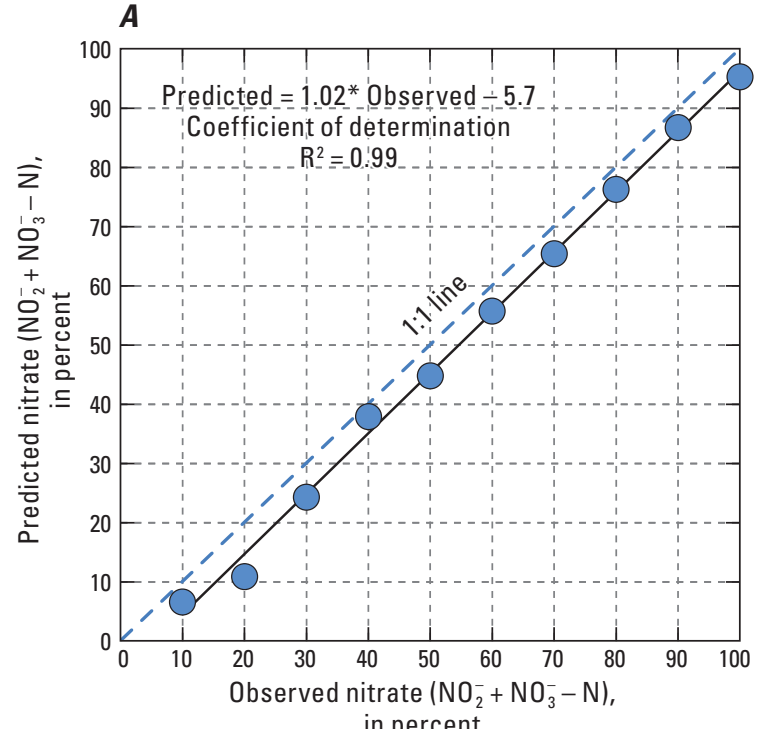

in percent

EXPLANATION

- Nitrate

Linear (nitrate)

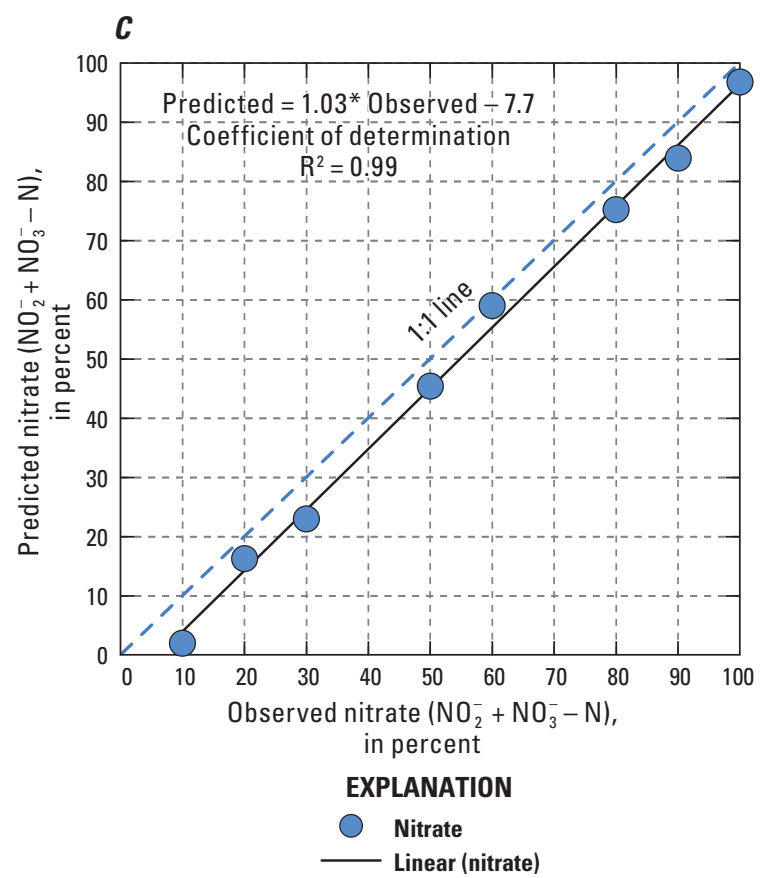

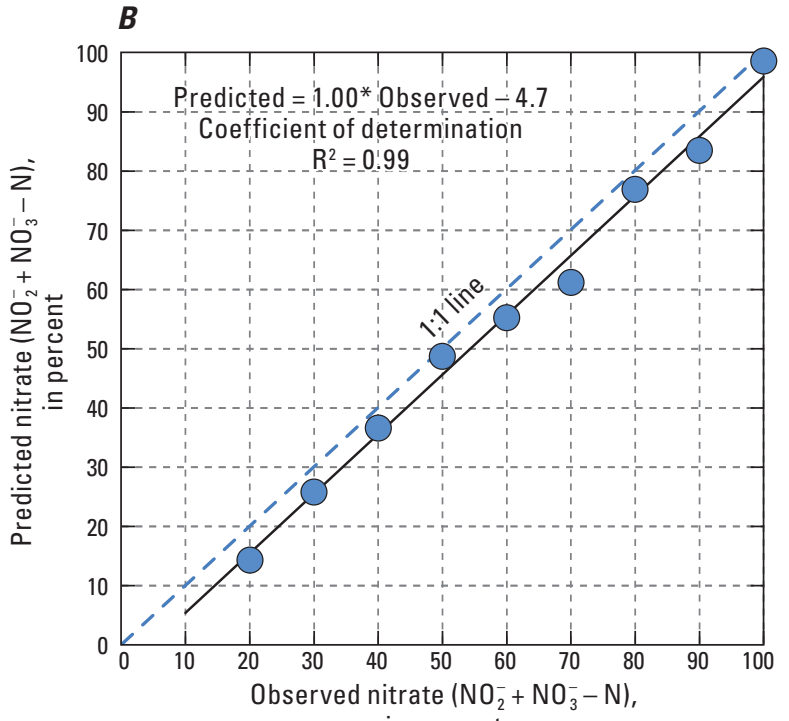

in percent

EXPLANATION

- Nitrate

Linear (nitrate)

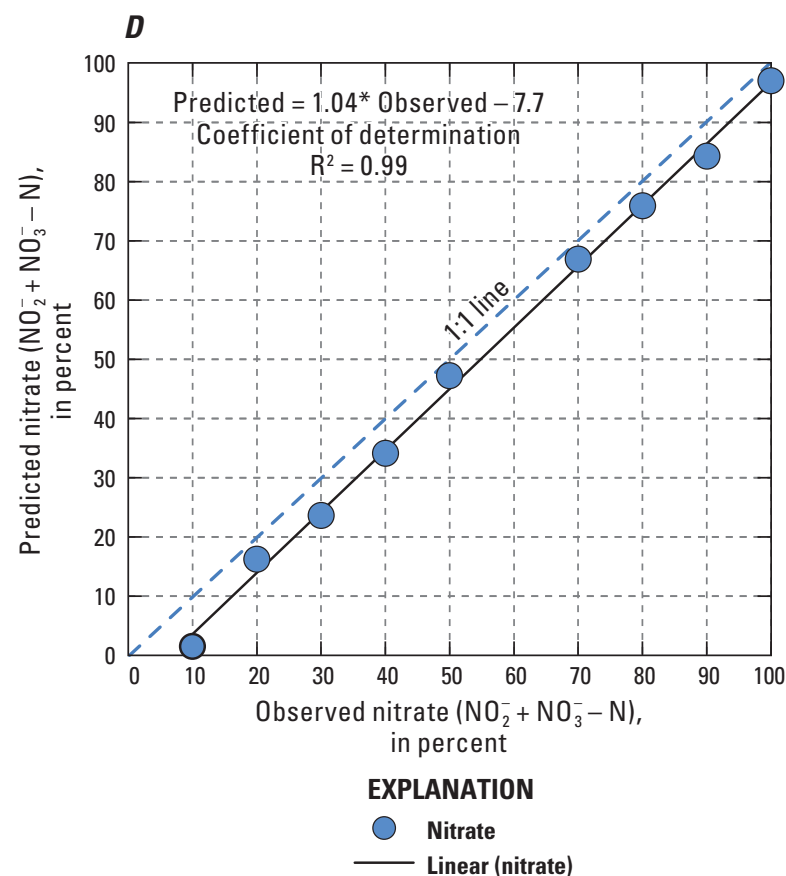

Figure 30. Calibration evaluation of the four $(A-D)$ logistic regression models developed in this investigation with details given in table 7. The analysis shows the percentage of observed nitrate $\left[\mathrm{NO}_{2}^{-}+\mathrm{NO}_{3}^{-}-\mathrm{N}\right]$ greater than specified concentration limits and the corresponding predicted probability of nitrate concentrations above the prescribed limits. 
matter were generally coincident with low levels of nitrate in groundwater, showing an inverse relation, possibly because of nitrate reduction by organic matter oxidation near the land surface (Appelo and others, 2005). Soil water storage to $25-\mathrm{cm}$ depth was hypothesized to be related to the flushing potential required to mobilize nitrate toward the water table. Areas with moderate to high available water storage were located in pockets along the eastern flank of the study area and in isolated areas to the north and west, with highest values observed near creek channels (fig. 15).

Vulnerability assessments of nitrate in groundwater included examining human effects related to land-use zoning, septic use, and agricultural effects in addition to natural factors. Vulnerability to low-level $(2.5 \mathrm{mg} / \mathrm{L})$ nitrate in groundwater was pervasive across the primary aquifer and related to depth to groundwater, septic zoning, and soil organic matter (fig. 32, table 7B). The results highlighted that septic zoning affects low-levels of nitrate concentrations in groundwater. The remaining indicator variables showed similar relations to the susceptibility analysis. Mid-level ( $5 \mathrm{mg} / \mathrm{L})$ vulnerability was examined using all 50 samples and with 48 of the samples with two outliers removed (figs. 33 and 34, table $7 C$ and $D$ ). Mid-level vulnerability using all 50 samples was related to depth to groundwater, if a location was within the agricultural region, simplified land use, soil water storage to $25-\mathrm{cm}$ depth, soil organic matter, and septic zoning within a 500-m radius. The land-use categories were further simplified for the logistic regression models because of sampling limitations into three basic categories: (a) all residential lots, (b) grazing, and (c) other land uses combined. Mid-level vulnerability using 48 samples produced the best overall fit and was related to the same variables except septic zoning. Therefore, without considering the effects of outliers at wells 1 and 2, septic zonation helped to distinguish only low-level nitrate concentrations, which was interpreted to indicate that septic zoning influenced low-level concentrations of nitrate in groundwater (table 7B). Soil properties and land use including the agricultural region were the main drivers of mid-level nitrate concentrations.

In general, the probabilities of exceeding low-level nitrate concentrations and overall aquifer susceptibility were high in most regions of the aquifer with the lowest probabilities mainly to the northwest along thin geologic deposits with shallow depth to groundwater (figs. 31-34). Probability of exceeding mid-level nitrate concentrations was generally high in the central part of the aquifer within the agricultural region and variable in other areas, depending on whether data outliers were considered in the analysis.

\section{Limitations}

There are limitations in the logistic regression approach to evaluate aquifer susceptibility and aquifer vulnerability. Logistic regression models do not simulate mechanisms that drive nitrate concentrations in groundwater as could be examined using a groundwater flow and transport model. The logistic regression models were conditioned using a static assessment of water quality from data collected in 2013 using only 50 samples, limiting their effectiveness in fully characterizing nitrate throughout the aquifer and for long-term projections under changing aquifer conditions. The probability maps derived from logistic regression models show the likelihood for areas to exceed low to moderate nitrate concentrations. Probability is a statistical measure of how likely an event will occur, which is not analogous to direct characterization. Although the probability maps show predictions of detections as a percent probability, there is uncertainty in model estimates shown by standard errors of the regression coefficients as well as operator biases from interpretative judgment and classifying effects. A model is inherently a simplified and imperfect representation of reality, but if developed well it will benefit the intended study.

The susceptibility and vulnerability probability maps produced from the logistic regression models provide baseline results for developing a consistent rating method across the study area but require verification at the field scale. The models did not consider point-source contamination, focused recharge, preferential groundwater flow, or other bypass mechanisms redirecting groundwater flow. Site-specific effects, such as improper well construction and local spills of contaminants, were also not included in the models. A well in a high-probability area is not necessarily contaminated, because contamination also can depend on the form of contaminant released, how much of that contaminant was released, and other explanatory variables not reflected in the dataset and therefore not taken into account by the logistic regression models. Additional site-specific data are needed before sitespecific decisions are made, such as the design of a wastewater-disposal system. The maps should be used in conjunction with expert field knowledge and direct field evaluations to provide a complete package of effective resource management.

\section{Future Needs}

Continued monitoring will be beneficial to evaluate changes in water quality in the Upper Black Squirrel Creek Basin. Future sampling could include filling spatial data gaps where water quality has not been measured, particularly in areas where land-use effects may be substantial. Overall, the largest data gaps are in areas of the aquifer outside of the agricultural region (fig. 21). Future sampling could target potential chemical releases from subdivisions, commercial operations, wastewater treatment plants, and irrigated areas to better understand local effects to groundwater quality. Under sampled land uses over relatively small portions of the study areas, such as urban areas, industrial areas, residential lots less than 2.5 acres, and commercial land should be directly identified to determine isolated, but potentially important effects on water quality. Vertical stratification of groundwater quality could be examined at a few locations to differentiate between shallow and deep conditions in the primary aquifer, which was not distinguished in the current investigation. 


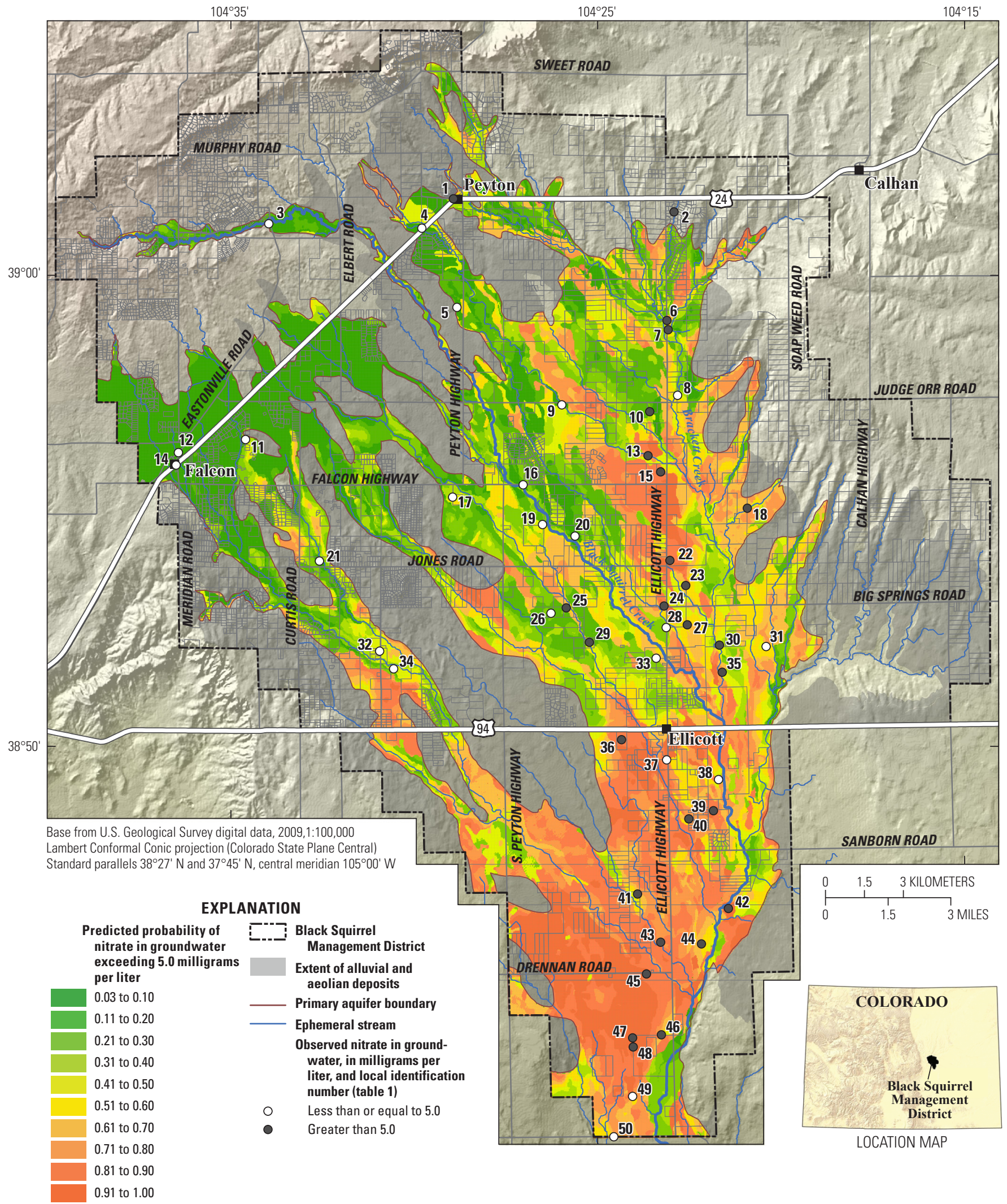

Figure 31. Mid-level aquifer susceptibility (all samples) given as the probability of detecting nitrate concentrations in groundwater greater than 5 milligrams per liter, Upper Black Squirrel Creek Basin, Colorado, 2013. Table 7A shows the model parameters and model fit from logistic regression. 


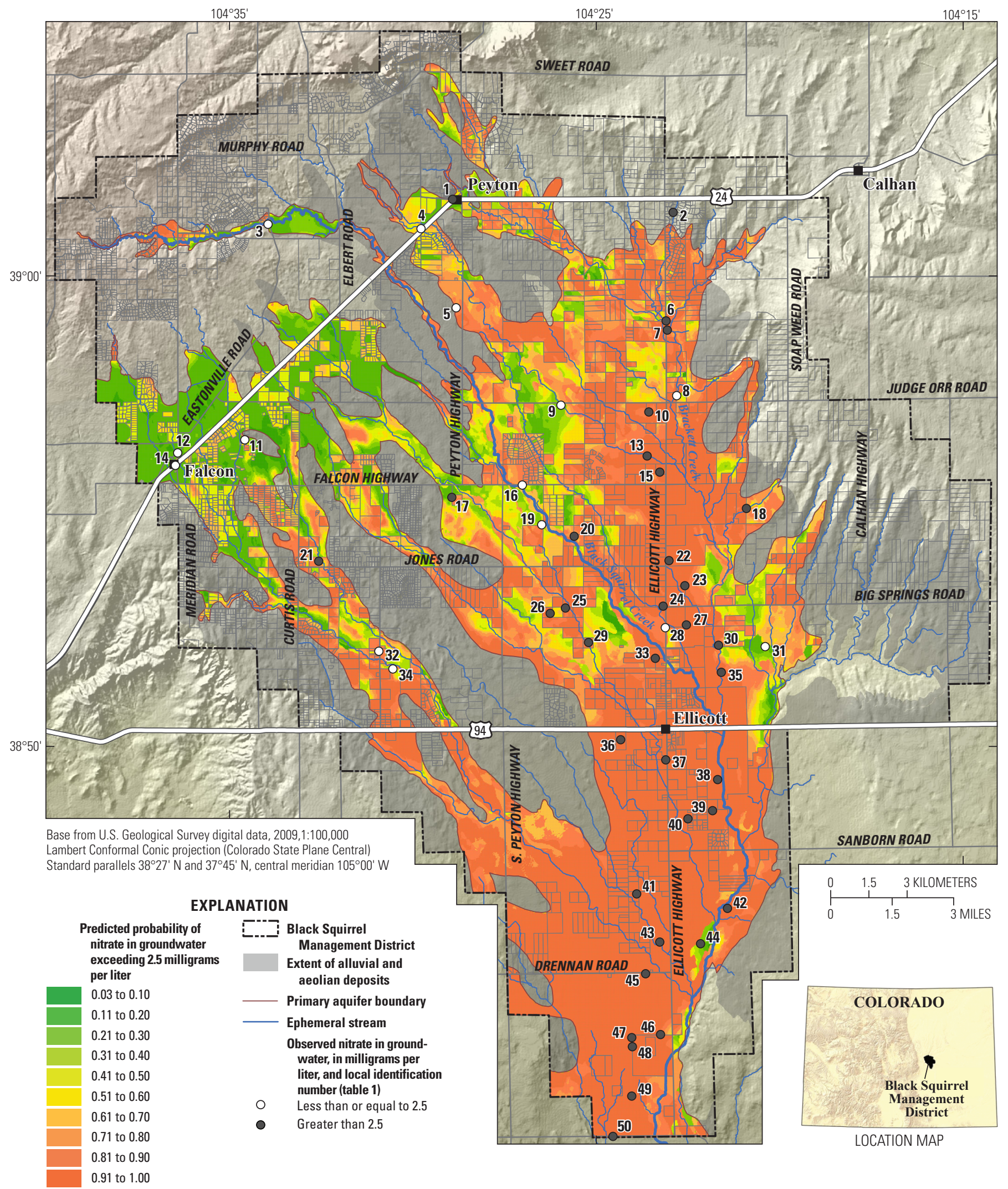

Figure 32. Low-level aquifer vulnerability (all samples) given as the probability of detecting nitrate concentrations in groundwater greater than 2.5 milligrams per liter, Upper Black Squirrel Creek Basin, Colorado, 2013. Table $7 B$ shows the model parameters and model fit from logistic regression. 


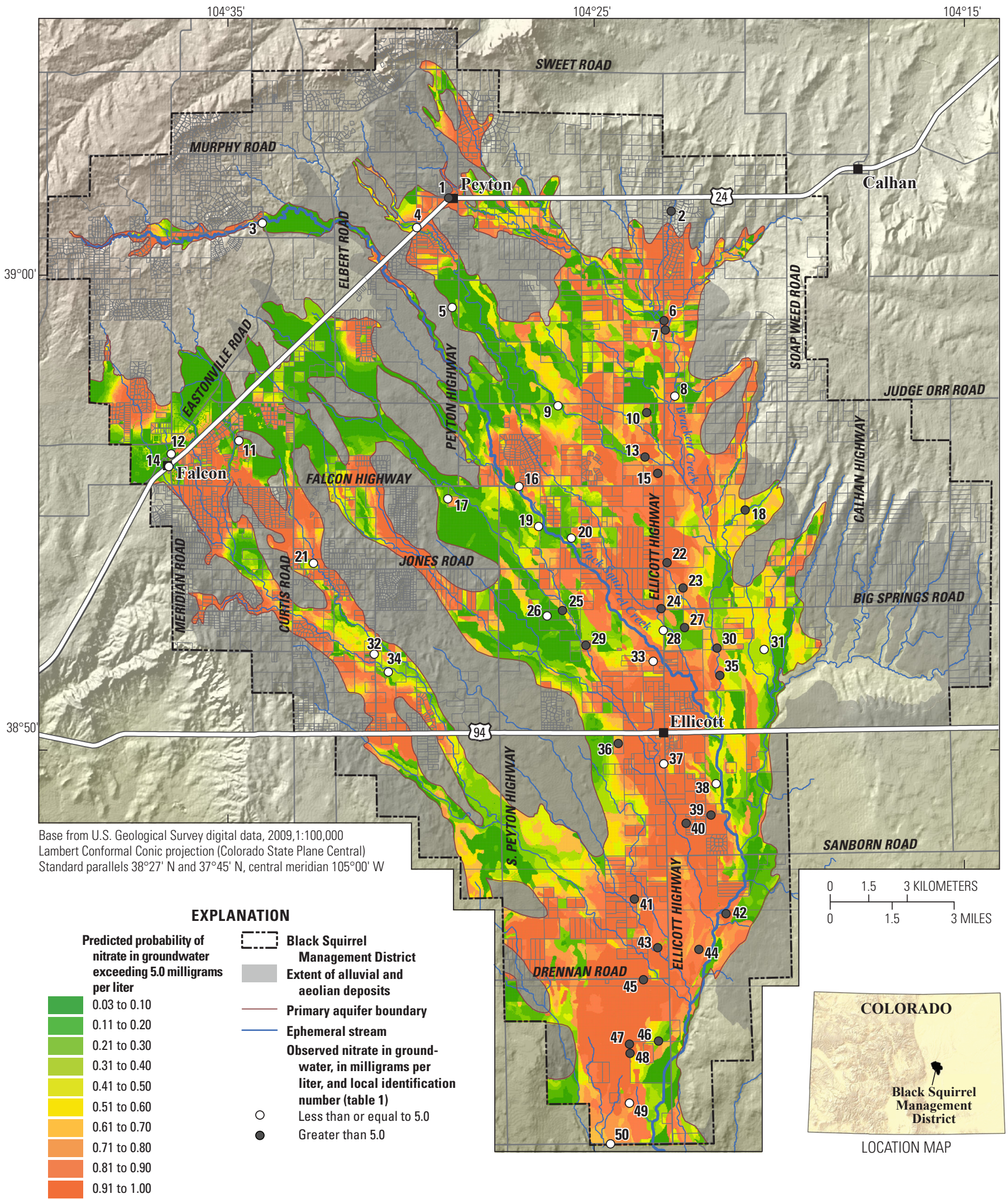

Figure 33. Mid-level aquifer vulnerability (all samples) given as the probability of detecting nitrate concentrations in groundwater greater than 5 milligrams per liter, Upper Black Squirrel Creek Basin, Colorado, 2013. Table $7 C$ shows the model parameters and model fit from logistic regression. 


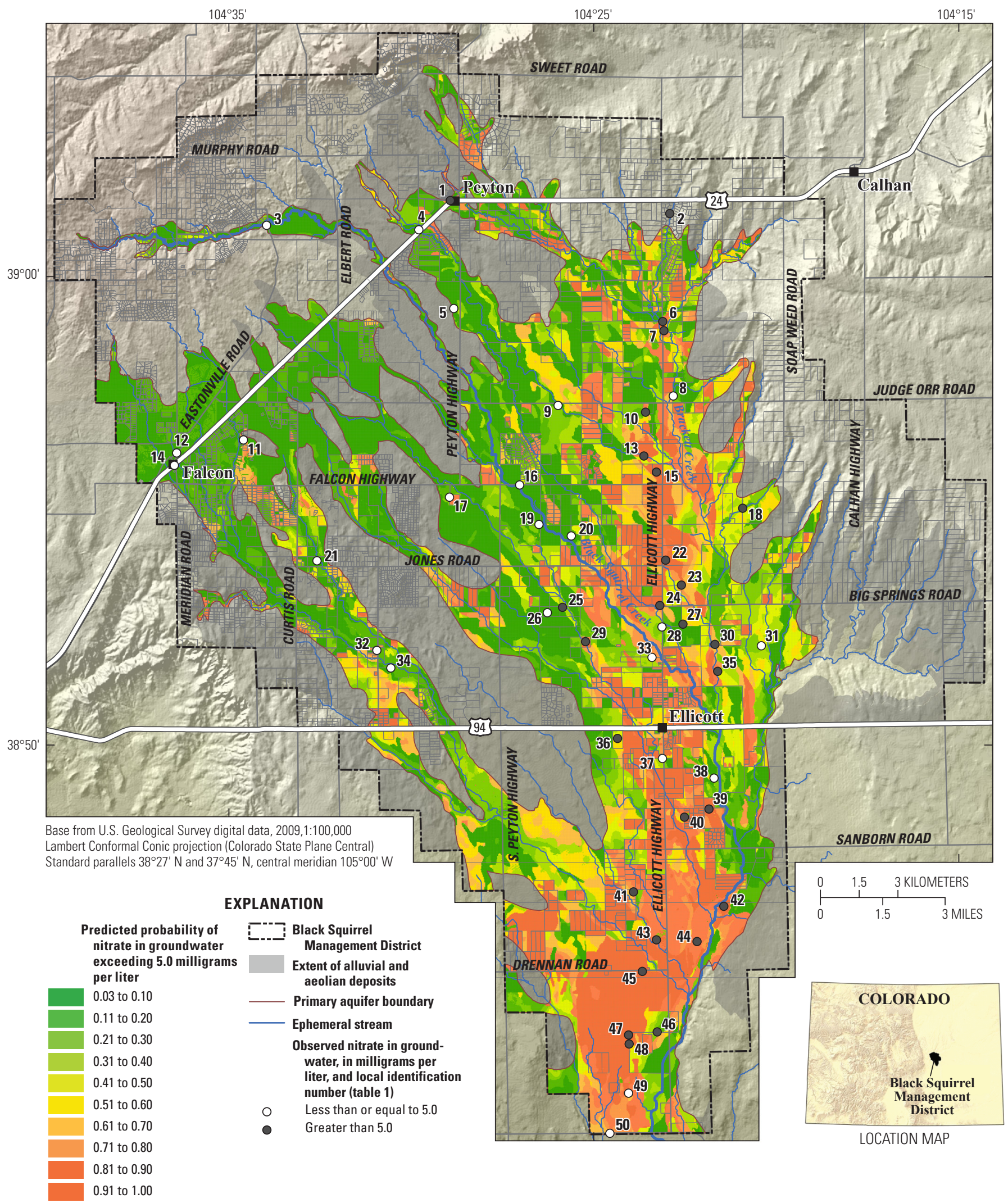

Figure 34. Mid-level aquifer vulnerability (two outliers removed) given as the probability of detecting nitrate concentrations in groundwater greater than 5 milligrams per liter, Upper Black Squirrel Creek Basin, Colorado, 2013. Table 7D shows the model parameters and model fit from logistic regression. 
Over time, wells could be periodically monitored for water quality, perhaps every couple of years, to evaluate temporal trends. Wells sampled with fuel detections, particularly the monitoring wells installed during this investigation that showed fuel detections, could be resampled to confirm residual contaminants from installation. Additional waterlevel measurements through time will be beneficial to capture seasonal and annual groundwater conditions in the aquifer. Future assessments of water-quality and water-quantity data collected over regular increments will help inform decision makers on important issues of land-use planning and regional development.

Additional geochemical techniques could be used to improve characterization of factors that affect groundwater quality. Although estimates of nitrogen contributions could be associated indirectly to land use and septic use in the present study, water-quality sampling was not designed to differentiate between nitrate sources (that is, agricultural, human, and livestock). Nitrogen and oxygen isotopes in nitrate could help to define nitrate sources (Kendall and McDonnell, 1998). Other methods to distinguish nitrate sources include analyses of ammonia and sodium plus potassium in relation to nitrate concentrations, for instance, to partition sources between agriculture and livestock. Sampling of both chloride and bromide may be useful to distinguish septic system effects from other nitrate sources (Mullaney and others, 2009). Constituents of human origin such as caffeine, personal care products, and pharmaceuticals could also be targeted, which discharge from septic systems. Additional work could target defining types, locations, and timing of nitrogen inputs to the primary aquifer.

A groundwater flow and transport model would be useful to evaluate groundwater movement, groundwatersurface-water interaction, and contaminant transport. Prior groundwater flow models, while useful, performed mainly basic assessments of the water budget (Buckles and Watts, 1988; Watts, 1995). Analyses from a comprehensive flow and transport model could be used to examine transport pathways and source areas associated with municipal and public-supply wells (for example, Paschke, 2007). Examining transport pathways and associated migration rates would provide estimates of recovery times for constituents to move through the aquifer, which is relevant to determining expected lag times following changes in land use and development. Transport times to evaluate recharge through the unsaturated zone could also be important because of residual nitrate retained in the soil; nitrate could continue to enter the groundwater from recharge long after land-use changes have been in practice. Other analyses could be used to determine wellhead protection zones, which will be important considerations as development continues for both selecting new site locations and in mitigating effects on water quality at existing wells. The effects of proposed changes in land use and development could be evaluated as a precursor to implementation, which would be useful for planners to consider prior to finalizing legislation.

\section{Summary}

The primary aquifer of the Upper Black Squirrel Creek Basin is located about 25 kilometers east of Colorado Springs, Colorado, and is a valuable source of water for irrigation, domestic, and commercial use. Changes in land use and development over the last decade, which include substantial growth of subdivisions, have led to uncertainty on the potential effects to water quality throughout the basin. This study is the second project phase (Phase II) focused on characterizing groundwater quality and groundwater age. As part of this study, groundwater-quality samples were collected in May and June 2013 from 50 randomly selected wells. The set of 50 wells consisted of 42 established wells and 8 new monitoring wells constructed at key locations to improve data coverage, advance scientific understanding, and enhance monitoring efforts.

Major-ion data indicate that groundwater representative of the primary aquifer was classified as calcium-sodium bicarbonate type water. Other water samples from wells located mainly along the periphery of the primary aquifer had cationanion compositions consistent with multiple water sources, including groundwater inputs from the underlying bedrock aquifers. These areas with differentiable water sources were located mainly where alluvial deposits were thin and geologic contacts to the underlying bedrock aquifers were relatively shallow, which eventually mix with inputs of water from other sources in the primary aquifer and become altered geochemically by the in-situ conditions.

Nitrate in groundwater was elevated above the estimated background concentration of natural recharge waters in 88 percent (44 of 50) of sites sampled. Nitrate concentrations were above the U.S. Environmental Protections Agency (EPA) maximum contaminant level (MCL) of 10 milligrams per liter $(\mathrm{mg} / \mathrm{L})$ in 10 percent of the samples and above half of the MCL $(5 \mathrm{mg} / \mathrm{L})$ in 54 percent of the samples. The results show that human effects on nitrate concentrations in groundwater are common in the study area, which is consistent with regional findings across the Denver Basin determined from alluvial and shallow bedrock wells. Dissolved-oxygen concentrations exceeded $0.5 \mathrm{mg} / \mathrm{L}$ in 95 percent of reported values (40 of 42 samples) and exceeded $2.0 \mathrm{mg} / \mathrm{L}$ in 90 percent of reported values ( 38 of 42 samples). The oxidized conditions observed in most areas indicate that nitrate from fertilizers and animal or human waste was geochemically stable and could persist in the groundwater for decades or perhaps longer. For other constituents, secondary maximum contaminant levels, which are not health concerns and affect mainly taste, color, or odor of the water, were observed in rare instances for $\mathrm{pH}$ ( 2 samples), chloride (1 sample), iron (3 samples), and manganese (8 samples). The secondary maximum contaminant level for total dissolved solids was also exceeded for two samples. 


\section{Groundwater Quality, Age, and Susceptibility to Nitrate Contamination, Upper Black Squirrel Creek Basin, 2013}

Apparent groundwater ages were estimated from chlorofluorocarbons and tritium data by using models that assume piston flow with binary mixing (dilution of a young component with old, tracer-free water). The mean and median groundwater ages were about 30 years and the standard deviation was 6 years, indicating that most groundwater in the primary aquifer originated from recharge to the aquifer in the last few decades. The median fraction of post-1950s (young) water was about 71 percent; remaining groundwater predated the 1950s, which may have originated from deeper geologic formations or may be caused by slow moving groundwater within the primary aquifer. Some of the oldest groundwater was observed in the upper reaches of the aquifer to the northwest where surficial, unconsolidated sediment deposits are thin and directly overlie the bedrock, supporting the paradigm of geochemically distinct groundwater entering the primary aquifer from below. Groundwater that had reached the central part of the aquifer from upgradient areas of the basin was more variable in age because of differences in flow paths and travel velocities. The analysis showed that travel times through the aquifer are usually on the order of decades. As a result, current (2013) land-use practices around the time of this investigation could affect water quality for decades to come, especially for relatively stable constituents, such as nitrate under oxidized geochemical conditions in the groundwater.

Fuel products (including acetone, benzene, diisopropyl ether, ethylbenzene, methyl acetate, methyl tertiary butyl ether (MTBE), methyl tert-pentyl ether, m- + p-xylene, o-xylene, tert-amyl alcohol, tert-butyl alcohol, tert-butyl ethyl ether, and toluene) were analyzed in groundwater from 49 of the 50 wells. Water from 7 sites had detections for fuel compounds; all concentrations were below the MCLs. The sources of these detections were not identified. Future samples should be collected in order to confirm whether fuel products were introduced to the groundwater during drilling of the monitoring wells. The analyses of fuel products provide a valuable baseline for landuse planners to evaluate future trends of fuel constituents in the groundwater as the region is further developed.

A historical analysis of nitrate concentrations measured at irregular locations and frequencies over the last three decades showed that median nitrate concentrations have increased approximately $1 \mathrm{mg} / \mathrm{L}$ from 4.3 to $5.4 \mathrm{mg} / \mathrm{L}$, although the distributions of observed nitrate for each period examined were similar to one another. Moreover, direct inspection indicates 60 percent reduction in the overall increase in median nitrate concentrations from 1995 to 2015 as compared to 1985 to 1995 , perhaps as nitrogen inputs trended closer toward equilibrium with nitrogen exports from the aquifer. Analyses of nitrate concentrations using nonparametric correlation coefficients from the Kendall Tau-B, Kendall Tau-C, and Spearman rank methods and the parametric correlation coefficient from the Pearson method show values between about 0.05 and 0.15 ; indicating there may have been small annual increases in nitrate over the study area. Additional analyses were used to test the significance of the predicted small annual increases in nitrate. Results from the Kruskal-Wallis test did not differentiate between nitrate distributions evaluated over 5-year periods with a $p$-value of 0.594 , providing no indication there were significant increases in nitrate beyond expected variability in the data. Moreover, the Mann-Kendall test and seasonal (quarterly) Kendall test used to remove seasonal fluctuations did not indicate significant monotonic trends (increases) in nitrate concentration over time with $p$-values above 0.350 . Although it was determined that nitrate concentrations may increase or decrease through time at discrete locations, additional analyses did not show a significant regional increase in nitrate concentration. Given irregularities in the data record, however, the results were interpreted as inconclusive for dismissing the potential for regional changes in nitrate. Additional monitoring of groundwater quality at established locations and sampling intervals would be beneficial to examine temporal trends.

Nitrate concentrations in the groundwater were evaluated for relations to land use, which showed that agriculture and septic use were the primary sources of nitrate. An agricultural region was defined using a sequence of land satellite imagery from 1999, 2006, and 2014. The analysis of land satellite imagery highlighted that crop locations have changed over time and that recently irrigated crops are only one of multiple potential nitrate sources affecting groundwater quality. Groundwater flow directions interpreted from median water-table elevations measured from 2000 to 2013 were used in conjunction with cropland locations to define the agricultural region by encompassing potential pathways of nitrate transport in the groundwater from nitrogen-based fertilizers. Mann-Whitney and Kruskal-Wallis nonparametric statistical tests show that median nitrate concentration $(6.7 \mathrm{mg} / \mathrm{L})$ was significantly greater for areas inside the agricultural region as compared to areas outside the agricultural region $(2.3 \mathrm{mg} / \mathrm{L})$. Except for one outlier well (well 1) at the northern boundary of the aquifer, the agricultural region contained all sample locations with concentrations of nitrate in groundwater above the EPA drinking-water standard (MCL of $10 \mathrm{mg} / \mathrm{L}$ ). Outside the agricultural region, analysis for septic use also showed significantly higher nitrate concentrations in septic areas $(4.9 \mathrm{mg} / \mathrm{L})$ compared to nonseptic areas $(1.7 \mathrm{mg} / \mathrm{L})$.

Inside the agricultural region, irrigation on crops was the primary input of nitrate and accounted for about 65 percent of all nitrate sources. Remaining nitrate contributions were about 23 percent from septic systems, 8 percent from grazing, 4 percent from residential uses, and 0.1 percent from commercial and county land uses combined, which included vacant land. Outside the agricultural region, septic systems were the primary source of nitrate and accounted for about 66 percent of all nitrate sources. Remaining nitrate contributions were 18 percent from grazing, 15 percent from residential uses, and 1 percent from irrigation, commercial, and county land uses combined. In terms of overall effect by land use, as measured by nitrate loading per land-use area, irrigation on crops was the dominant mechanism delivering nitrate to the groundwater. 
Effluent from septic systems had the second highest effect on nitrate loading to the groundwater. Areas of grazing and residential uses showed comparable levels of nitrate effect but at levels well below those of irrigation and septic uses. The lowest effect occurred from commercial and county land uses.

Residential establishments drawing from wells in the agricultural region raised a key point; it is important in addition to considering potential effects caused by land uses to consider effects from surrounding land uses at their proposed locations. Residential lots within the agricultural region, for example, are more vulnerable to nitrate concentrations than areas outside of the agricultural region.

Probability maps were developed from logistic regression models to examine the potential for nitrate contamination in the groundwater. A mid-level $(5 \mathrm{mg} / \mathrm{L})$ susceptibility analysis examined natural relations between nitrate concentrations and climatic, hydrologic, and geologic variables; significant variables were identified as depth to groundwater, soil organic matter, and soil water storage to $25-\mathrm{cm}$ depth. Vulnerability to low-level $(2.5 \mathrm{mg} / \mathrm{L})$ nitrate was best related to depth to groundwater, septic zoning, and soil organic matter. The results were interpreted to indicate that septic zoning affected low-level nitrate concentrations (greater than $2.5 \mathrm{mg} / \mathrm{L}$ ). After removing two data outliers, mid-level $(5.0 \mathrm{mg} / \mathrm{L})$ vulnerability was best related to depth to groundwater, land use, soil organic matter, soil water storage to $25-\mathrm{cm}$ depth, and if a location was within the agricultural region. Overall, soil properties, land use (including the agricultural region), and depth to groundwater were the main factors related to nitrate in groundwater.

The results of this investigation offer the foundational information needed for developing best management practices to mitigate nitrate contamination, basic concepts to aid public education, and information to guide regulatory measures if policy makers determine this is warranted. Science-based decision making will be critical for stabilizing groundwater quality, preserving water supply for existing users, and ensuring balanced economic growth. Continued monitoring of water quality in the Upper Black Squirrel Creek Basin will be needed to evaluate potential effects on water quality and to fill existing data gaps. The process of lowering nitrate concentrations in groundwater under stable geochemical conditions by changes in land use will likely be gradual, controlled in part by hydrodynamics of the aquifer and geochemical conditions. In practical terms, planning decisions enacted today could be important for several decades to come.

\section{References Cited}

Akaike, H., 1974, A new look at the statistical model identification: IEEE Transactions on Automatic Control, v. 19, p. 716-723.

Allison, P.D., 1991, Logistic regression using the SAS system - Theory and application: Cary, N.C., SAS Institute Inc., $288 \mathrm{p}$.

Appelo, C.A.J., and Postma, D., 2005, Geochemistry, groundwater and pollution: CRC Press, $2 \mathrm{~d}$ ed., $668 \mathrm{p}$.

Banta, E.R., 1989, Hydrologic effects of pumpage from the Denver Basin bedrock aquifers of northern El Paso County, Colorado: U.S. Geological Survey Water-Resources Investigations Report 88-4033, 84 p.

Bauch, N.J., Musgrove, M.L., Mahler, B.J., and Paschke, S.S., 2014, The quality of our Nation's waters - Water quality in the Denver Basin aquifer system, Colorado, 2003-05: U.S. Geological Survey Circular 1357, 100 p., http://dx.doi.org/10.3133/ $\operatorname{cir} 1357$.

Bingham, D.L., and Klein, J.M., 1974, Water-level decline, spring 1964 to spring 1974, upper Black Squirrel Creek basin, Colorado: U.S. Geological Survey Open-File Map, scale 1:63,360, 1 sheet.

Brendle, Daniel, 1997, Have nitrate concentrations changed in water in the alluvial aquifer of the Upper Black Squirrel Creek Basin since 1984?: U.S. Geological Survey Fact Sheet 072-97, accessed May 22, 2014, at http://pubs.er.usgs.gov/publication/ fs07297.

Buckles, D.R., and Watts, K.R., 1988, Geohydrology, water quality, and preliminary simulations of groundwater flow of the primary aquifer in the Upper Black Squirrel Creek Basin, El Paso County, Colorado: U.S. Geological Survey Water-Resources Investigations Report 88-4017, 49 p.

Burnham, K.P., and Anderson, D.R., 2002, Model selection and multimodel inference-A practical informationtheoretic approach: Springer-Verlag, New York, NY, 488 p.

Busenberg, Eurybiades, and Plummer, L.N., 1992, Use of chlorofluoromethanes $(\mathrm{CCl} 3 \mathrm{~F}$ and $\mathrm{CCl} 2 \mathrm{~F} 2)$ as hydrologic tracers and age-dating tools_-Example, the alluvium and terrace system of central Oklahoma: Water Resources Research, v. 28, no. 9, p. 2257-2283.

Druliner, A.D., Chen, H.H., and McGrath, T.S., 1996, Relations of nonpoint-source nitrate and atrazine concentrations in the High Plains aquifer to selected explanatory variables in six Nebraska study areas: U.S. Geological Survey WaterResources Investigations Report 95-4202, 51 p. 
Domagalski, J.L., and Johnson, Henry, 2012, Phosphorus and groundwater-Establishing links between agricultural use and transport to streams: U.S. Geological Survey Fact Sheet 2012-3004, 4 p.

Fishman, M.J., and Friedman, L.C., 1989, Methods for determination of inorganic substances in water and fluvial sediments: U.S. Geological Survey Techniques of WaterResources Investigations, book 5, chap. A1, 545 p.

Fishman, M.J., ed., 1993, Methods of analysis by the U.S. Geological Survey National Water Quality LaboratoryDetermination of inorganic and organic constituents in water and fluvial sediments: U.S. Geological Survey Open-File Report 93-125, 217 p.

Focazio, M.J., Reilly, T.E., Rupert, M.G., and Helsel, D.R., 2002, Assessing groundwater vulnerability to contaminationProviding scientifically defensible information for decision makers: U.S. Geological Survey Circular 1224, 33 p.

Freeze, R.A., and Cherry, J.A., 1979, Groundwater: Englewood Cliffs, N.J., Prentice-Hall, 604 p.

Green, G.N., 1992, The digital geologic map of Colorado in ARC/INFO format: U.S. Geological Survey Open-File Report 92-507, metadata accessed May 27, 2014, at http://geo-nsdi.er.usgs.gov/metadata/open-file/92-507/ metadata.faq.html.

Gurdak, J.J., and Qi, S.L., 2006, Vulnerability of recently recharged ground water in the High Plains aquifer to nitrate contamination: U.S. Geological Survey Scientific Investigations Report 2006-5050, 39 p.

Gurdak, J.J., Hanson, R.T., McMahon, P.B., Bruce, B.W., McCray, J.J., Thyne, G.D., and Reedy, R.C., 2007, Climate variability controls on unsaturated water and chemical movement, High Plains aquifers, USA: Vadose Zone Journal, v. 6, no. 2, p. 533-547, accessed December 2012, at http://co.water.usgs.gov/publications/non-usgs/ Gurda07Clima.pdf.

Gurdak, J.J., McMahon, P.B., Dennehy, K.F., and Qi, S.L., 2009, Water quality in the High Plains aquifer, Colorado, Kansas, Nebraska, New Mexico, Oklahoma, South Dakota, Texas, and Wyoming, 1999-2004: U.S. Geological Survey Circular 1337, 63 p.

Helsel, D.R., and Hirsch, R.M., 1992, Statistical methods in water resources: New York, Elsevier Science Publishing Company, Inc., 522 p.

Hosmer, D.W., and Lemeshow, Stanley, 1989, Applied logistic regression: New York, John Wiley \& Sons, Inc., 307 p.

Jurgens, B.C., Böhlke, J.K., and Eberts, S.M., 2012, TracerLPM (Version 1)-An Excel ${ }^{\circledR}$ workbook for interpreting groundwater age distributions from environmental tracer data: U.S. Geological Survey Techniques and Methods Report, book 4, chap. F3, 60 p., accessed May 23, 2014, at http:/ca.water.usgs.gov/user_projects/TracerLPM/.
Kendall, Carol, and McDonnell, J.J., eds., 1998, Isotope tracers in catchment hydrology: Elsevier Science B.V., Amsterdam, 839 p.

Kleinbaum, D.G., 1994, Logistic regression, a self-learning text: New York, Springer-Verlag, 282 p.

Koterba, M.T., Banks, W.S.L., and Shedlock, R.J., 1993, Pesticides in shallow groundwater in the Delmarva Peninsula: Journal of Environmental Quality, v. 22, no. 3, p. 500-518.

Lucas L.L., and Unterweger, M.P., 2000, Comprehensive review and critical evaluation of the half-life of tritium: Journal of Research of the National Institute of Standards and Technology, v. 105, no. 4, p. 541-549.

McFadden, Daniel, 1974, Conditional logit analysis of qualitative choice behavior, in Zarembka, P., ed., Frontiers in econometrics: Academic Press, p. 105-142.

McGovern, H.E., and Jenkins, E.D., 1966, Ground water in Black Squirrel Creek valley, El Paso County, Colorado: U.S. Geological Survey Hydrologic Investigations Atlas 236, 2 sheets, various scales.

McMahon, P.B., Dennehy, K.F., Bruce, B.W., Gurdak, J.J., and Qi, S.L., 2007, Water-quality assessment of the High Plains aquifer, 1999-2004: U.S. Geological Survey Professional Paper 1749, 136 p.

McMahon, P.B., and Chapelle, F.H., 2008, Redox processes and water quality of selected principal aquifer systems: Groundwater, v. 4, p. 259-271. doi: 10.1111/j.1745-6584.2007.00385.x

Minitab Inc., 2010, Minitab 17 Statistical Software: State College, PA. accessed December 15, 2014, at http://support.minitab. com/en-us/minitab/17/macro-library/macro-files/anova-andregression-macros/roc-receiver-operating-characteristic-curve/

Mullaney, J.R., Lorenz, D.L., Arntson, A.D., 2009, Chloride in groundwater and surface water in areas underlain by the glacial aquifer system, northern United States: U.S. Geological Survey Scientific Investigations Report 2009-5086, $41 \mathrm{p}$.

Musgrove, M., Beck, J.A., Paschke, S.S., Bauch, N.J., and Mashburn, S.L., 2014, Quality of groundwater in the Denver Basin aquifer system, Colorado, 2003-5: U.S. Geological Survey Scientific Investigations Report 2014-5051, 107 p., http://dx.doi.org/10.3133/sir20145051.

National Research Council, 1993, Ground water vulnerability assessment, contamination potential under conditions of uncertainty: Washington, D.C., National Academy Press, 210 p., accessed December 15, 2000, at http://books.nap.edu/ books/0309047994/html.

Natural Resources Conservation Service, variously dated, Web soil survey: accessed on February 25, 2014, at http://websoilsurvey.nrcs.usda.gov/.

Nolan, B.T., and Clark, M.L., 1997, Selenium in irrigated agricultural areas of the western United States: Journal of Environmental Quality, v. 26, no. 3, p. 849-857. 
Nolan, B.T., and Hitt, K.J., 2002, Nutrients in shallow ground waters beneath relatively undeveloped areas in the conterminous United States: U.S. Geological Survey WaterResources Investigations Report 2002-4289, 17 p.

Paschke, Suzanne S., ed., 2007, Hydrogeologic settings and groundwater flow simulations for regional studies of the transport of anthropogenic and natural contaminants to public-supply wells - Studies begun in 2001: U.S. Geological Survey Professional Paper 1737-A, 244 p.

Paschke, S.S. ed., 2011, Groundwater availability of the Denver Basin aquifer system, Colorado: U.S. Geological Survey Professional Paper 1770, 274 p.

Piper, A.M., 1944, A graphic procedure in the geochemical interpretation of water analyses: Transactions, American Geophysical Union, v. 25, p. 914-923.

Plummer, L.N., and Busenberg, Eurybiades, 1999, Chlorofluorocarbons-Tools for dating and tracing young groundwater, in Cook, P., and Herczeg, A., eds., Environmental tracers in subsurface hydrology: Boston, Kluwer Academic Publishers, chap. 15, p. 441-478.

Plummer, L.N., Busenberg, Eurybiades, and Cook, P.G., 2006, Principles of chlorofluorocarbon dating, in International Atomic Energy Agency, Use of chlorofluorocarbons in hydrology - A guidebook: Vienna, International Atomic Energy Agency, p. 17-29.

Plummer, L.N., Michel, R.L., Thurman, E.M., and Glynn, P.D., 1993, Environmental tracers for age dating young ground water, in Alley, W.M., ed., Regional groundwater quality: New York, Van Nostrand Reinhold, p. 255-294.

PRISM Climate Group, 2012, United States average annual precipitation, 1981-2010, Corvallis, Oreg., Oregon State University, accessed February 27, 2014, at http:// prism.oregonstate.edu.

Rao, P.S.C., and Alley, W.M., 1993, Pesticides: New York, Van Nostrand Reinhold, 112 p.

Ross, S.M., 2014, Introduction to probability and statistics for engineers and scientists (5th ed.): Academic Press, $686 \mathrm{p}$.

Rupert, M.G., 1998, Probability of detecting atrazine/desethylatrazine and elevated concentrations of nitrate $\left(\mathrm{NO}_{2}+\mathrm{NO}_{3}-\mathrm{N}\right)$ in ground water in the Idaho part of the upper Snake River Basin: U.S. Geological Survey Water-Resources Investigations Report 98-4203, 32 p., 1 pl., accessed March 10, 2001, at http://pubs.er.usgs.gov/publication/wri984203.

Rupert, M.G., 2003, Probability of detecting atrazine/ desethyl-atrazine and elevated concentrations of nitrate in ground water in Colorado: U.S. Geological Survey WaterResources Investigations Report 2002-4269, 35 p.
Rupert, M.G., and Plummer, L.N., 2009, Groundwater quality, age, and probability of contamination, Eagle River watershed valley-fill aquifer, north-central Colorado, 2006-2007: U.S. Geological Survey Scientific Investigations Report 2009-5082, 59 p.

Scott, G.R., 1974, Reconnaissance geologic map of El Paso County, Colorado: U.S. Geological Survey Open-File Report 74-334, 1 sheet, scale 1:187,500.

Scott, J.C., 1990, Computerized stratified random site selection approaches for design of a groundwater quality sampling network: U.S. Geological Survey Water-Resources Investigations Report 90-4101, 109 p.

Soil Survey Staff, 1999, Soil taxonomy-A basic system of soil classification for making and interpreting soil surveys ( $2 \mathrm{~d}$ ed.): Natural Resources Conservation Service, U.S. Department of Agriculture Handbook, 436 p.

Soister, P.E., 1968, Geologic map of the Hanover NW quadrangle, El Paso County, Colorado: U.S. Geological Survey Geologic Quadrangle Map GQ-725, scale 1:24,000.

SPSS, Inc., 2000, SYSTAT 10, Statistics I-Software documentation: Chicago, SPSS, Inc., 663 p.

SYSTAT Software, Inc., 2004, SYSTAT 11, Statistics IISoftware documentation: Richmond, Calif., SYSTAT Software, Inc., 657 p.

Tesoriero, A.J., and Voss, F.D., 1997, Predicting the probability of elevated nitrate concentrations in the Puget Sound Basin-Implications for aquifer susceptibility and vulnerability: Ground Water, v. 35, no. 6, p. 1029-1039.

Topper, Ralf, 2008, Upper Black Squirrel Creek Basin aquifer recharge and storage evaluation: Colorado Geological Survey, unpublished report prepared for the El Paso Water Authority, accessed May 23, 2014, at http://geosurvey.state.co.us/water/ Storage\%20Alternatives/Pages/UpperBlackSquirrel.aspx.

Topper, Ralf, and Horn, Andy, 2011, El Paso County Groundwater Quality Study Phase 1: Colorado Geological Survey, unpublished report prepared for the El Paso Groundwater Quality Study Committee for presentation to the El Paso County Board of County Commissioners, accessed May 22, 2014 at http://geosurvey.state.co.us/water/Water\%20Quality/ Pages/WaterQuality.aspx.

Tweto, Ogden, comp., 1979, Geologic map of Colorado: U.S. Geological Survey, 1 sheet, scale 1:500,000.

Upper Black Squirrel Creek Ground Water Management District, 2009, Rules and regulations and statement of policy: Colorado Department of Natural Resources, Division of Water Resources, as amended through February 3, 2009, available at http://water.state.co.us/DWRDocs/Rules/Pages/ CGWCRules.aspx. 
U.S. Environmental Protection Agency, 1993, A review of methods for assessing aquifer sensitivity and ground water vulnerability to pesticide contamination: U.S. Environmental Protection Agency, EPA/813/R-93/002, 147 p.

U.S. Environmental Protection Agency, 2009, Drinking water contaminants: U.S. Environmental Protection Agency, Office of Water, EPA 816-F-09-0004, accessed July 14, 2014, at http://www.epa.gov/safewater/contaminants/index.html.

U.S. Geological Survey, variously dated, National field manual for the collection of water-quality data: U.S. Geological Survey Techniques of Water-Resources Investigations, book 9, chaps. A1-A9, accessed December 2008, at http://pubs.water.usgs.gov/twri9A.

U.S. Geological Survey, 1999a, National elevation dataset: U.S. Geological Survey Fact Sheet 148-99, 2 p., accessed July 22, 2008, at http://pubs.usgs.gov/fs/1999/0148/.

U.S. Geological Survey, 1999b, The National Hydrography Dataset: U.S. Geological Survey Fact Sheet 106-99, 2 p., accessed July 22, 2008, at http://pubs.er.usgs.gov/publication/ fs10699.

U.S. Geological Survey, 2006, Methane in West Virginia ground water: U.S. Geological Survey Fact Sheet 2006-3011, 2 p., accessed on July 21, 2014, at http://pubs.usgs.gov/ fs $/ 2006 / 3011 /$.
U.S. Geological Survey, 2007, The Reston Chlorofluorocarbon Laboratory: accessed May 6, 2007, at http:/water.usgs.gov/lab/.

Vittinghoff, E. and McCulloch, C.E., 2007, Relaxing the rule of ten events per variable in logistic and cox regression: American Journal of Epidemiology, v. 165, p. 710-718, http://dx.doi.org/10.1093/aje/kwk052.

Vowinkel, E.F., Clawges, R.M., Buxton, D.E., Stedfast, D.A., and Louis, J.B., 1996, Vulnerability of public drinking water supplies in New Jersey to pesticides: U.S. Geological Survey Fact Sheet FS 165-96, 3 p.

Watts, K.R., 1995, Hydrogeology and simulation of flow between the alluvial and bedrock aquifers in the Upper Black Squirrel Creek Basin, El Paso County, Colorado: U.S. Geological Survey Water-Resources Investigations Report 94-4238, 82 p., accessed May 22, 2014, at http://pubs.er.usgs.gov/publication/ wri944238.

Werner, Wilfried, 2009, Fertilizers, 6. Environmental aspects: Ullmann's Encyclopedia of Industrial Chemistry, DOI: 10.1002/14356007.n10_n05.

Wieczorek, M.E., 2014, Area- and depth-weighted averages of selected SSURGO variables for the conterminous United States and District of Columbia: U.S. Geological Survey Data Series 866, http://dx.doi.org/10.3133/ds866. 
Appendix 1 
Table 1-1. Wells to estimate historical depth to groundwater during 1975-2015, set 1 of 4.

[NWIS, National Water Information System; USGS, U.S. Geological Survey; NAD 83, North American Datum of 1983; NAVD 88, North American Vertical Datum of 1988. Information from USGS NWIS, http://dx.doi.org/10.5066/F7P55KJN]

\begin{tabular}{|c|c|c|c|c|c|c|c|c|}
\hline Purpose & $\begin{array}{c}\text { Data } \\
\text { source }\end{array}$ & Agency & $\begin{array}{c}\text { Site } \\
\text { identification }\end{array}$ & $\begin{array}{l}\text { Station } \\
\text { name }\end{array}$ & $\begin{array}{l}\text { Data } \\
\text { type }\end{array}$ & $\begin{array}{c}\text { Latitude, } \\
\text { NAD } 83\end{array}$ & $\begin{array}{l}\text { Longitude, } \\
\text { NAD } 83\end{array}$ & $\begin{array}{l}\text { Elevation, } \\
\text { NAVD 88, } \\
\text { in meters }\end{array}$ \\
\hline Historical & NWIS & USGS & 384256104241102 & SC01506325BCC2 & Manual & 38.7155833 & -104.4030278 & 1,723 \\
\hline Historical & NWIS & USGS & 384743104220501 & SC01406232BBB & Manual & 38.79527299 & -104.3685751 & 1,789 \\
\hline Historical & NWIS & USGS & 384927104230101 & SC01406218CCD1 & Manual & 38.82416149 & -104.3841313 & 1,821 \\
\hline Historical & NWIS & USGS & 384929104210201 & SC01406217DDD & Manual & 38.82471675 & -104.3510749 & 1,810 \\
\hline Historical & NWIS & USGS & 385017104220601 & SC01406217BBB & Manual & 38.83804999 & -104.3688532 & 1,824 \\
\hline Historical & NWIS & USGS & 385111104220601 & SC01406205CCC & Manual & 38.8530497 & -104.3688534 & 1,838 \\
\hline Historical & NWIS & USGS & 385113104210401 & SC01406205DDD & Manual & 38.8536051 & -104.3516307 & 1,837 \\
\hline Historical & NWIS & USGS & 385130104214201 & SC146205CAA2 & Manual & 38.85832734 & -104.3621865 & 1,840 \\
\hline Historical & NWIS & USGS & 385234104220501 & SC01306232BCC & Manual & 38.87610485 & -104.3685757 & 1,860 \\
\hline Historical & NWIS & USGS & 385247104331501 & SC01306433AAD1 & Manual & 38.8797169 & -104.5546917 & 1,981 \\
\hline Historical & NWIS & USGS & 385439104223601 & SC01306219ABB & Manual & 38.9108265 & -104.3771873 & 1,892 \\
\hline Historical & NWIS & USGS & 385609104361102 & SC01306407BDB & Manual & 38.93582709 & -104.6035824 & 2,085 \\
\hline Historical & NWIS & USGS & 385808104224101 & SC01206230CDD1 & Manual & 38.968881 & -104.3785767 & 1,953 \\
\hline Historical & NWIS & USGS & 385609104361102 & SC01306407BDB & Manual & 38.93582709 & -104.6035824 & 2,085 \\
\hline Historical & NWIS & USGS & 385609104361102 & SC01306407BDB & Manual & 38.93582709 & -104.6035824 & 2,085 \\
\hline Historical & NWIS & USGS & 384323104233801 & SC01506325ABB2 & Manual & 38.723052 & -104.3944092 & 1,726 \\
\hline Historical & NWIS & USGS & 384348104233001 & SC01506324DBA & Manual & 38.7299964 & -104.3921868 & 1,732 \\
\hline Historical & NWIS & USGS & 384442104243201 & SC01506314ACD & Manual & 38.74477778 & -104.4085833 & 1,758 \\
\hline Historical & NWIS & USGS & 384756104213301 & SC01406229DCB & Manual & 38.79888396 & -104.359686 & 1,787 \\
\hline Historical & NWIS & USGS & 384814104205801 & SC01406221CCB & Manual & 38.80388378 & -104.3499636 & 1,799 \\
\hline Historical & NWIS & USGS & 385055104214701 & SC01406208BDB & Manual & 38.8486053 & -104.3635754 & 1,831 \\
\hline Historical & NWIS & USGS & 385204104245301 & SC01306335DCC & Manual & 38.86744444 & -104.4131944 & 1,873 \\
\hline Historical & NWIS & USGS & 384756104213301 & SC01406229DCB & Manual & 38.79888396 & -104.359686 & 1,787 \\
\hline Historical & NWIS & USGS & 385247104223501 & SC01306231ABB & Manual & 38.87971597 & -104.3769093 & 1,900 \\
\hline Historical & NWIS & USGS & 385658104233501 & SC01306301ACB & Manual & 38.94943707 & -104.3935769 & 1,932 \\
\hline Historical & NWIS & USGS & 384544104222001 & SC01506207AD & Manual & 38.7621111 & -104.3723694 & 1,765 \\
\hline Historical & NWIS & USGS & 384823104224001 & SC01406230AB & Manual & 38.8064 & -104.3777194 & 1,798 \\
\hline Historical & NWIS & USGS & 385148104233101 & SC01406301AD & Manual & 38.8633611 & -104.392 & 1,854 \\
\hline
\end{tabular}


Table 1-2. Wells to estimate historical depth to groundwater during 1975-2015, set 2 of 4.

[NWIS, National Water Information System; USGS, U.S. Geological Survey; NAD 83, North American Datum of 1983; NAVD 88, North American Vertical Datum of 1988. Information from USGS NWIS, http://dx.doi.org/10.5066/F7P55KJN]

\begin{tabular}{|c|c|c|c|c|c|c|c|c|}
\hline Purpose & $\begin{array}{c}\text { Data } \\
\text { source }\end{array}$ & Agency & $\begin{array}{c}\text { Site } \\
\text { identification }\end{array}$ & $\begin{array}{l}\text { Station } \\
\text { name }\end{array}$ & $\begin{array}{l}\text { Data } \\
\text { type }\end{array}$ & $\begin{array}{l}\text { Latitude, } \\
\text { NAD } 83\end{array}$ & $\begin{array}{l}\text { Longitude, } \\
\text { NAD } 83\end{array}$ & $\begin{array}{l}\text { Elevation, } \\
\text { NAVD 88, } \\
\text { in meters }\end{array}$ \\
\hline Historical & NWIS & USGS & 385202104203201 & SC01406204 & Manual & 38.86723889 & -104.3421806 & 1,849 \\
\hline Historical & NWIS & USGS & 385209104252001 & SC01306335CC & Manual & 38.86911944 & -104.4222194 & 1,868 \\
\hline Historical & NWIS & USGS & 385227104231402 & SC01306231 & Manual & 38.87418056 & -104.3873694 & 1,866 \\
\hline Historical & NWIS & USGS & 385246104262201 & SC01306334BB & Manual & 38.8795 & -104.4394806 & 1,904 \\
\hline Historical & NWIS & USGS & 385530104270601 & SC01306316BA & Manual & 38.9250111 & -104.4517306 & 1,952 \\
\hline Historical & NWIS & USGS & 385546104232201 & SC01306312DA & Manual & 38.92931944 & -104.3893694 & 1,920 \\
\hline Historical & NWIS & USGS & 385613104362801 & SC01306512AD & Manual & 38.93703056 & -104.6079306 & 2,089 \\
\hline Historical & NWIS & USGS & 385630104343901 & SC01306405DC & Manual & 38.9415611 & -104.5774806 & 2,084 \\
\hline Historical & NWIS & USGS & 385712104260201 & SC01306303 & Manual & 38.95321944 & -104.4340306 & 1,974 \\
\hline Historical & NWIS & USGS & 390058104301101 & SC01206412CB & Manual & 39.01601944 & -104.5029639 & 2,080 \\
\hline Historical & NWIS & USGS & 385202104203201 & SC01406204 & Manual & 38.86723889 & -104.3421806 & 1,849 \\
\hline Historical & NWIS & USGS & 385204104214801 & SC01306232CD & Manual & 38.8678111 & -104.3633306 & 1,881 \\
\hline Historical & NWIS & USGS & 385209104252001 & SC01306335CC & Manual & 38.86911944 & -104.4222194 & 1,868 \\
\hline Historical & NWIS & USGS & 385227104231402 & SC01306231 & Manual & 38.87418056 & -104.3873694 & 1,866 \\
\hline Historical & NWIS & USGS & 385246104262201 & SC01306334BB & Manual & 38.8795 & -104.4394806 & 1,904 \\
\hline Historical & NWIS & USGS & 385439104263501 & SC01306316DD & Manual & 38.9109111 & -104.44305 & 1,934 \\
\hline Historical & NWIS & USGS & 385458104210101 & SC01306216CB & Manual & 38.91618889 & -104.3502694 & 1,907 \\
\hline Historical & NWIS & USGS & 385530104270601 & SC01306316BA & Manual & 38.9250111 & -104.4517306 & 1,952 \\
\hline Historical & NWIS & USGS & 385546104232201 & SC01306312DA & Manual & 38.92931944 & -104.3893694 & 1,920 \\
\hline Historical & NWIS & USGS & 385613104362801 & SC01306512AD & Manual & 38.93703056 & -104.6079306 & 2,089 \\
\hline Historical & NWIS & USGS & 385630104343901 & SC01306405DC & Manual & 38.9415611 & -104.5774806 & 2,084 \\
\hline Historical & NWIS & USGS & 385712104260201 & SC01306303 & Manual & 38.95321944 & -104.4340306 & 1,974 \\
\hline Historical & NWIS & USGS & 384442104230801 & SC01506313ADD1 & Manual & 38.7449962 & -104.3860754 & 1,748 \\
\hline Historical & NWIS & USGS & 384505104241601 & SC01506314AAA1 & Manual & 38.7513852 & -104.4049648 & 1,766 \\
\hline Historical & NWIS & USGS & 384506104241301 & SC01506313BBB1 & Manual & 38.7515463 & -104.4047203 & 1,766 \\
\hline Historical & NWIS & USGS & 384532104235601 & SC01506312CAB1 & Manual & 38.75888504 & -104.399409 & 1,771 \\
\hline Historical & NWIS & USGS & 384547104232601 & SC01506312AAC & Manual & 38.76305156 & -104.3910756 & 1,768 \\
\hline
\end{tabular}


Table 1-3. Wells to estimate historical depth to groundwater during 1975-2015, set 3 of 4.

[NWIS, National Water Information System; USGS, U.S. Geological Survey; NAD 83, North American Datum of 1983; NAVD 88, North American Vertical Datum of 1988. Information from USGS NWIS, http://dx.doi.org/10.5066/F7P55KJN]

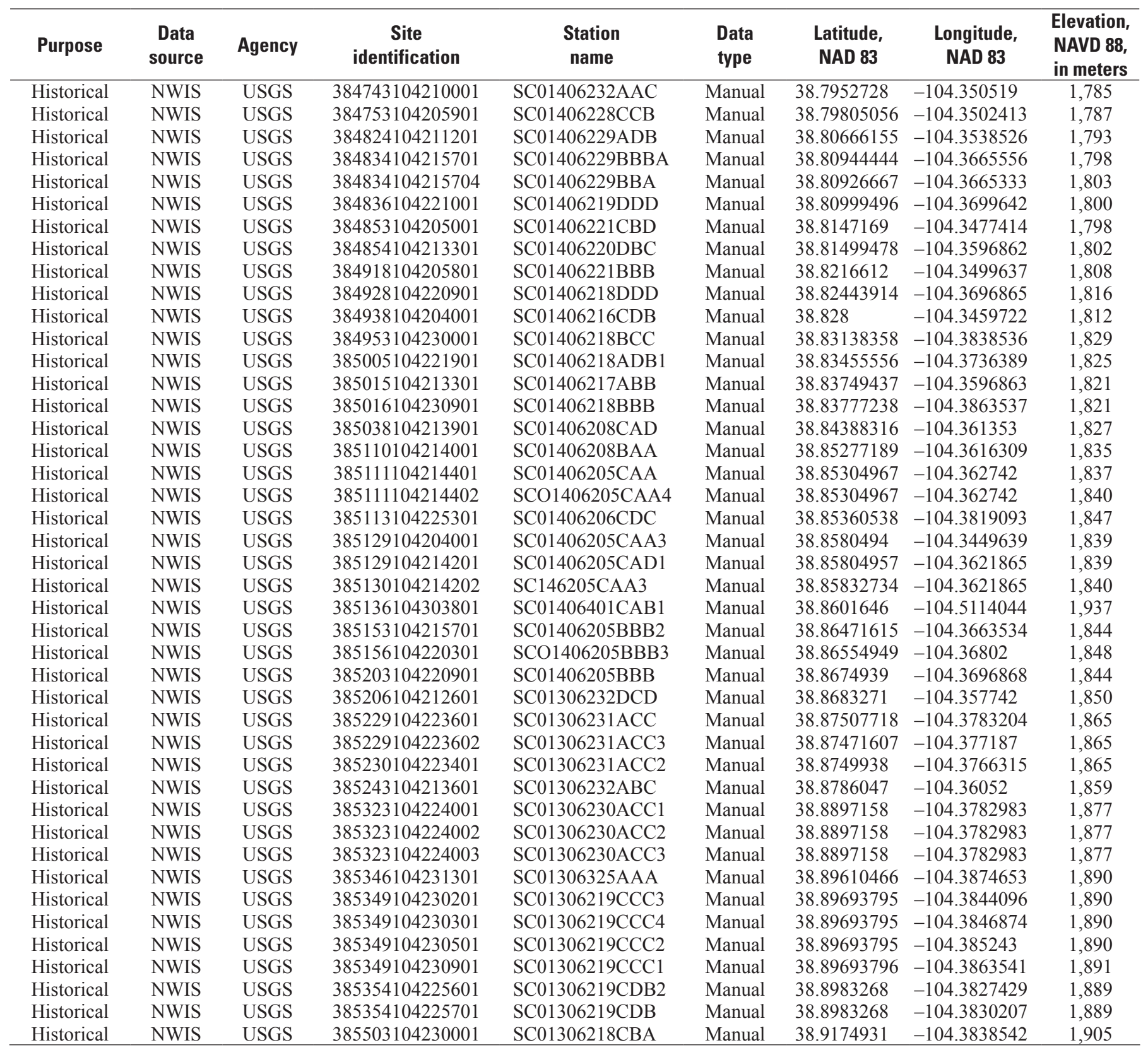


Table 1-4. Wells to estimate historical depth to groundwater during 1975-2015, set 4 of 4.

[NWIS, National Water Information System; USGS, U.S. Geological Survey; NAD 83, North American Datum of 1983; NAVD 88, North American Vertical Datum of 1988. Information from USGS NWIS, http://dx.doi.org/10.5066/F7P55KJN]

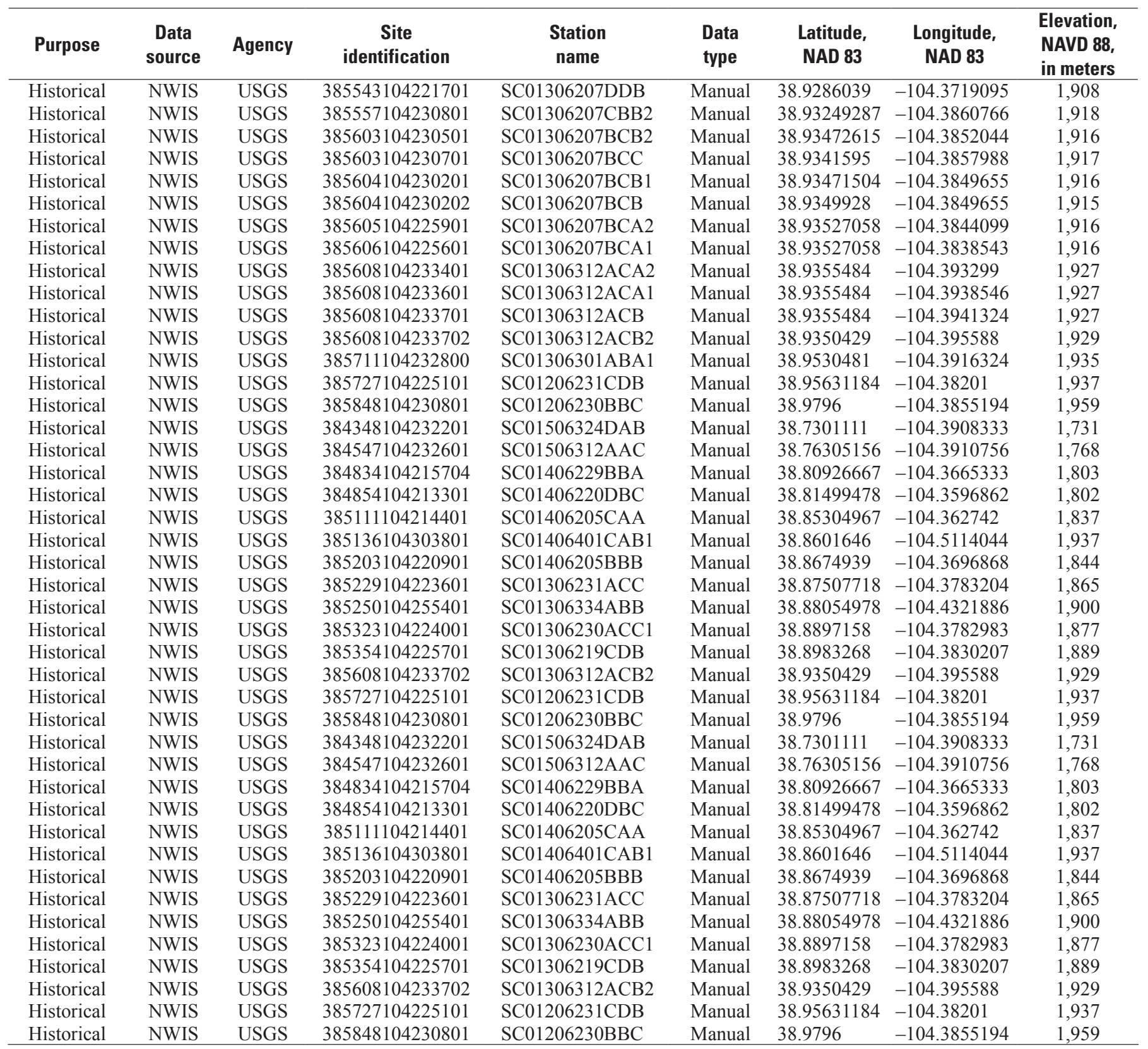


Table 1-5. Wells used to evaluate median water-table elevations during 2000-2013, set 1 of 2.

[NWIS, National Water Information System; USGS, U.S. Geological Survey; NAD 83, North American Datum of 1983; NAVD 88, North American Vertical Datum of 1988; dtw, depth to groundwater. Information from USGS NWIS, http://dx.doi.org/10.5066/F7P55KJN]

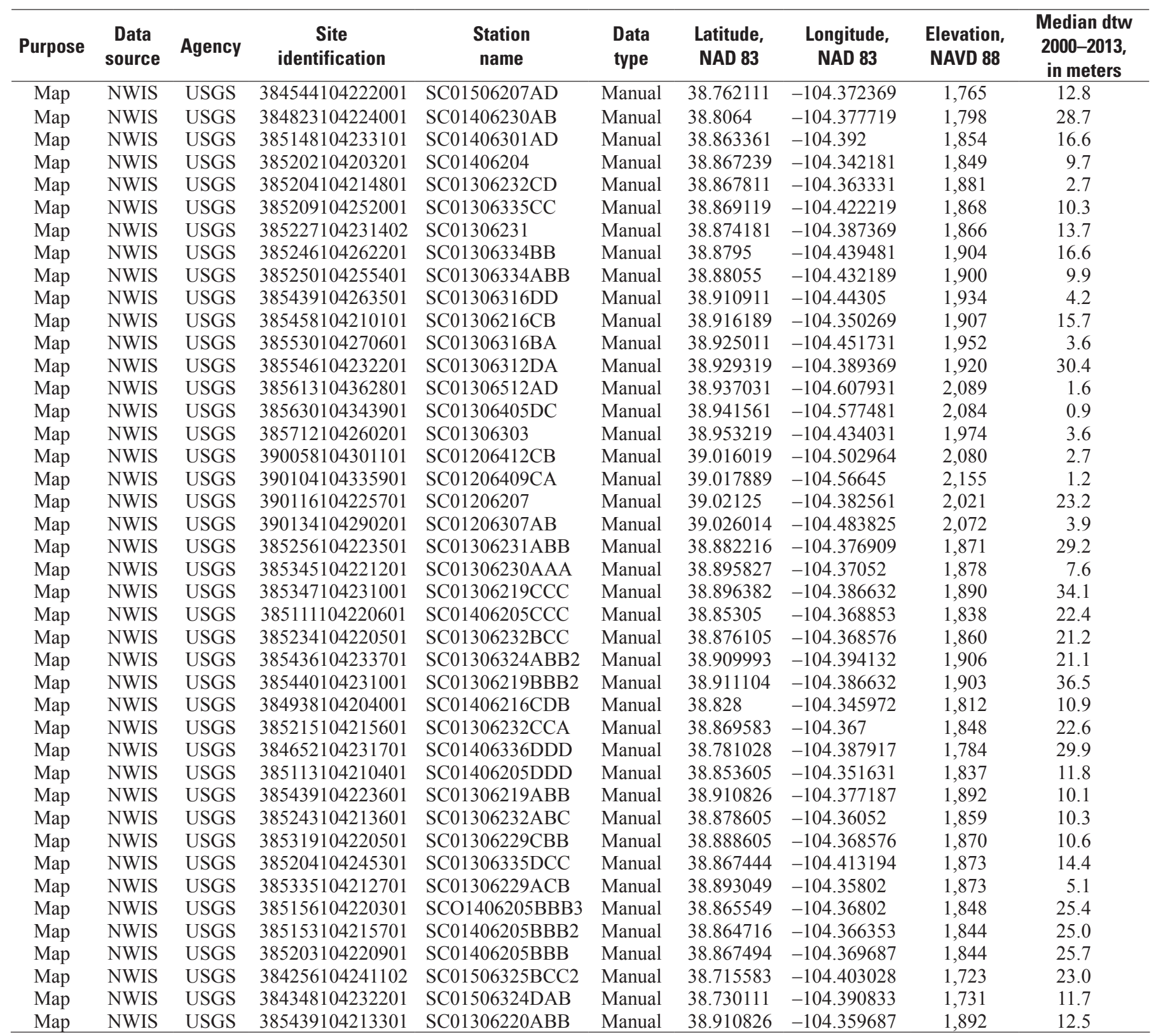


Table 1-6. Wells used to evaluate median water-table elevations during 2000-2013, set 2 of 2.

[NWIS, National Water Information System; USGS, U.S. Geological Survey; NAD 83, North American Datum of 1983; NAVD 88, North American Vertical Datum of 1988; dtw, depth to groundwater. Information from USGS NWIS, http://dx.doi.org/10.5066/F7P55KJN]

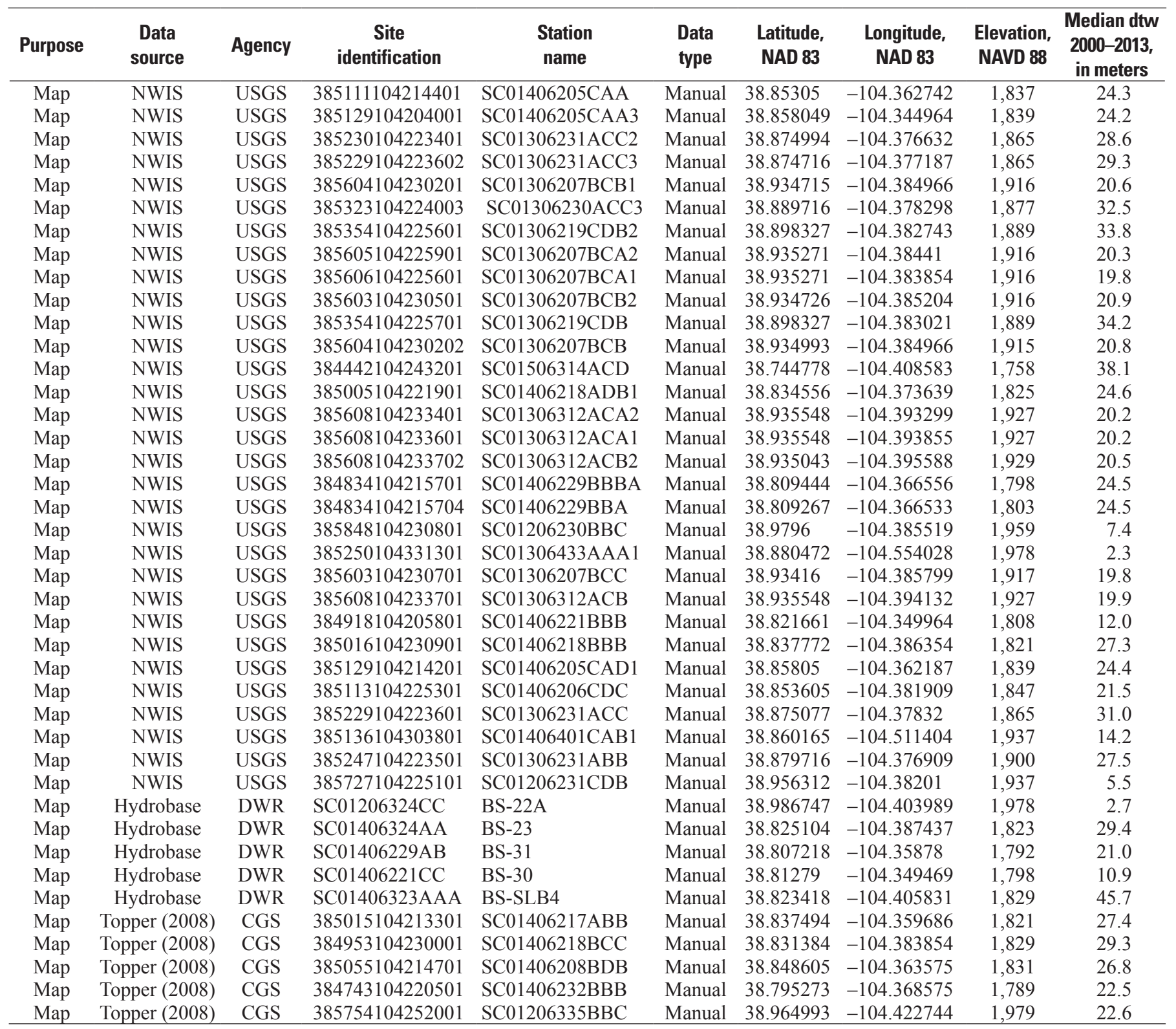


Table 1-7. Wells used to evaluate median nitrate concentration during 1985-2013, set 1 of 2.

[NWIS, National Water Information System; USGS, U.S. Geological Survey; NAD 83, North American Datum of 1983. Information from USGS NWIS, http://dx.doi.org/10.5066/F7P55KJN]

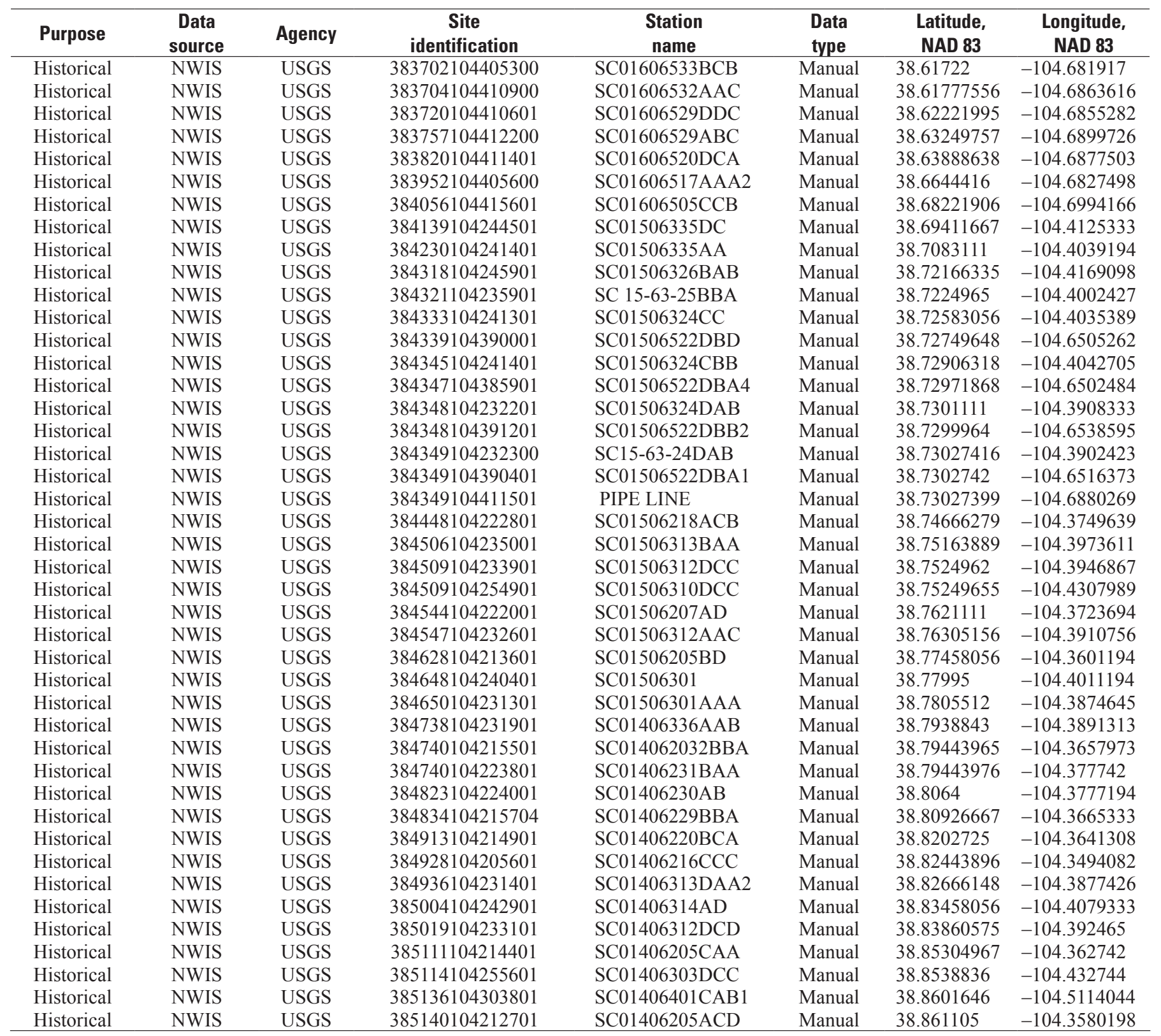


Table 1-8. Wells used to evaluate median nitrate concentration during 1985-2013, set 2 of 2.

[NWIS, National Water Information System; USGS, U.S. Geological Survey; NAD 83, North American Datum of 1983. Information from USGS NWIS, http://dx.doi.org/10.5066/F7P55KJN]

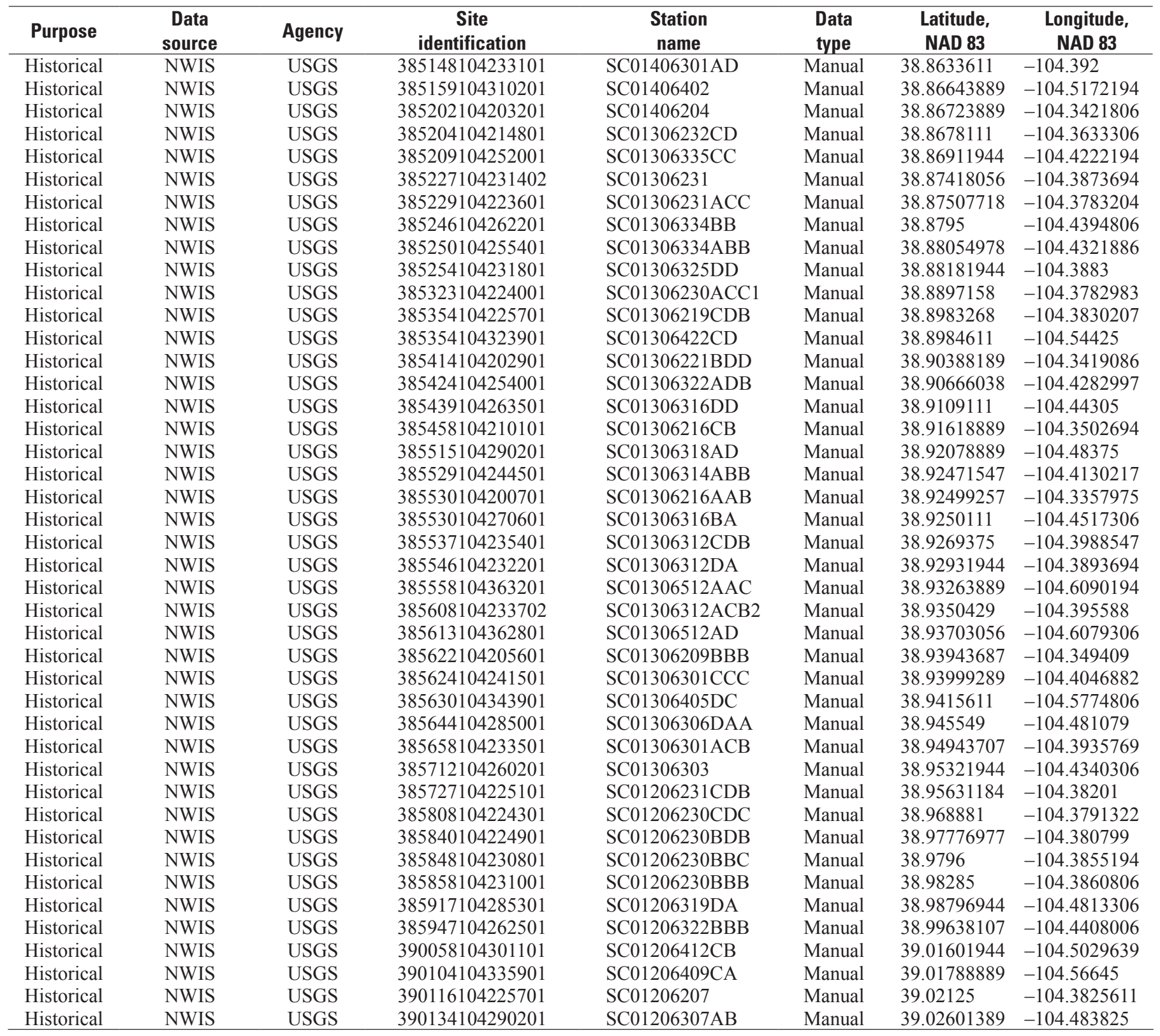


Publishing support provided by:

Denver Publishing Service Center, Denver, Colorado

For more information concerning this publication, contact: Director, USGS Colorado Water Science Center

Box 25046, Mail Stop 415

Denver, C0 80225

(303) 236-4882

Or visit the Colorado Water Science Center Web site at: http://co.water.usgs.gov/

This publication is available online at: http://dx.doi.org/10.3133/sir20165020 



\section{$\frac{\mathbb{3}}{3}$}

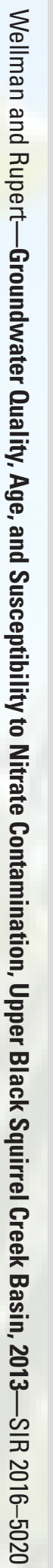

